Uniwersytet Przyrodniczy w Lublinie

\title{
Wybrane zagadnienia z zakresu przemysłu spożywczego oraz zarządzania i inżynierii produkcji
}

Tom 1

Środowisko - Roślina - Zwierzę - Produkt 
Wybrane zagadnienia

z zakresu przemysłu spożywczego

oraz zarządzania i inżynierii produkcji

Tom 1 
Środowisko - Roślina - Zwierzę - Produkt 


\title{
Wybrane zagadnienia z zakresu przemysłu spożywczego oraz zarządzania i inżynierii produkcji
}

\author{
Tom 1 \\ pod redakcją \\ Marka Babicza \\ Kingi Kropiwiec-Domańskiej
}




\author{
Recenzenci \\ dr hab. inż. Arkadiusz Gola \\ prof. dr hab. Małgorzata Krzywonos
}

\author{
Opracowanie redakcyjne \\ Magdalena Marcewicz \\ Korekta \\ Renata Zelik \\ Projekt okładki \\ Jacek Pałyszka
}

\title{
(9) $(1) \Theta \Theta$
}

Ten utwór jest dostępny na licencji Creative Commons Uznanie autorstwa Użycie niekomercyjne - Bez utworów zależnych 4.0 Międzynarodowe.

\section{ISBN 978-83-7259-326-9 on-line}

DOI: $10.24326 /$ mon.2020.5

\author{
giverip \\ Wydawnictwo Uniwersytetu Przyrodniczego w Lublinie \\ ul. Akademicka 15, 20-950 Lublin \\ www.wydawnictwo.up.lublin.pl \\ 8 ark. wyd.
}




\section{Spis treści}

Małgorzata Chęć, Monika Stoma, Agnieszka Dudziak

Zarządzanie laboratorium wzorcującym zgodnie z normą

PN-EN ISO/IEC 17025

Management of a calibration laboratory according to PN-EN ISO/IEC 17025

Aleksandra Chrapek, Katarzyna Dzida

Skład chemiczny, warunki uprawy i właściwości lecznicze

mięty pieprzowej (Mentha $\times$ piperita $\mathrm{L}$.)

Chemical composition, growing conditions and healing effects of peppermint

(Mentha $\times$ piperita L.)

Paula Ćwiek

Prozdrowotne właściwości wybranych nasion roślin strączkowych

Health benefits of selected legumes

Oliwia Lopatniuk, Dominika Krakowiak, Damian Laszczka, Natalia Flak,

Karolina Dobrosz, Justyna Bohacz

Liczebność mikroorganizmów oraz aktywność enzymów hydrolitycznych pleśni

wyizolowanych $\mathrm{z}$ wybranych przypraw dostępnych na rynku krajowym

The number of microorganisms and activity of hydrolytic enzymes of molds isolated from selected spices available on the domestic market

Magda Marciniewicz, Agnieszka Starek, Agnieszka Sagan

Wpływ parametrów pasteryzacji na właściwości chemiczne i mikrostrukturę soku pomidorowego

Influence of pasteurization parameters on chemical properties and microstructure

of tomato juice

Zuzanna Mariańczuk, Sylwia Michalak, Małgorzata Kowczyk-Sadowy

Badanie tekstury wybranych serów podpuszczkowych

Texture examination of selected rennet cheeses

Aleksandra Noga, Sybilla Nazarewicz, Lukasz Papież, Wiktor Bielawski,

Cezary Piecyk

Studia nad twardością liofilizatów z banana uzyskanych w zróżnicowanych

warunkach

Studies on hardness of freeze-dried bananas obtained in different conditions

Lukasz Papież, Sybilla Nazarewicz, Aleksandra Noga, Wiktor Bielawski,

Cezary Piecyk

Projekt i zestawienie stanowiska do pomiaru współczynnika wnikania ciepła

Desing and summary of results for measuring heat transfer

Dominika Pruś, Monika Stoma, Agnieszka Dudziak

Ocena świadomości wpływu sztucznej inteligencji na życie konsumentów

Assessment of awareness of artificial intelligence impact on the life of consumers

Anna Rodzeń, Monika Stoma

Zastosowanie metody SERVQUAL do oceny jakości usług transportowych

Application of the SERVQUAL method for assessing the quality of transport services 


\section{Piotr Stefaniak, Katarzyna Lisiecka}

Analiza zmienności współrzędnych barwy ekstrudatów paszowych w zależności od warunków procesu

Analysis of color coordinates variability of feed extrudates depending

on processing conditions

Magdalena Stobiecka, Jan Zdulski, Joanna Wajs, Sylwia Jańczuk

Zastosowanie i właściwości kwiatów chabra bławatka

(Centaurea cyanus)

Use and properties of cornflower (Centaurea cyanus)

Magdalena Szydłowska-Tutaj, Maciej Combrzyński, Urszula Zlotek,

Piotr Lewko, Marta Krajewska

Wpływ fortyfikacji na jakość wybranych produktów zbożowych

Impact of fortification on the quality of selected cereal products

Joanna Wajs, Magdalena Stobiecka

Znaczenie mlecznych produktów fermentowanych w diecie człowieka

Importance of fermented dairy products in the human diet 
Małgorzata Chęć ${ }^{1}$, Monika Stoma $\mathbb{B}^{2}$, Agnieszka Dudziak $\mathbb{D}^{3}$

\title{
Zarządzanie laboratorium wzorcującym zgodnie z normą PN-EN ISO/IEC 17025
}

\author{
Management of a calibration laboratory according to PN-EN ISO/IEC 17025
}

\section{Wstęp}

Norma PN-EN ISO/IEC 17025:2017 „Ogólne wymagania dotyczące kompetencji laboratoriów badawczych i wzorcujących" jest jednym z dokumentów, na podstawie którego laboratoria badawcze i wzorcujące mogą uzyskać potwierdzenie swojej bezstronności oraz tym samym zaufanie potencjalnych klientów. Jest to szczególnie istotnie $\mathrm{w}$ aspekcie problematyki zrównoważonego rozwoju, w tym ochrony środowiska.

Polski Komitet Normalizacyjny 31 stycznia 2018 r. zatwierdził obecną formę tego dokumentu, tym samym zastępując nieaktualną już normę PN-EN ISO/IEC 17025:2005. Dokument ten jest Normą Europejską utworzoną w języku angielskim, francuskim i niemieckim, jest przetłumaczony przez Polski Komitet Normalizacyjny na język polski. Powyższa norma obowiązuje w krajach należących do CEN i CENELEC, umożliwiając jednakowe działanie laboratoriów w wielu europejskich państwach [PN-EN ISO/IEC 17025:2017].

PN-EN ISO/IEC 17025:2017 zawiera wymagania ogólne obowiązujące w laboratoriach akredytowanych, a także wymagania dotyczące: struktury, zasobów, procesu, systemu zarządzania. Norma ta została skierowana ściśle do laboratoriów badawczych oraz wzorcujących chcących uzyskać potwierdzenie swoich kompetencji [PN-EN ISO/IEC 17025:2017].

Certyfikacja zgodnie z powyższą normą nazywana jest akredytacją. Akredytacja ta ma na celu wyodrębnić pewne jednostki posiadające jednakowe i odpowiednie kompetencje, zapewniające całkowitą obiektywność wykonywanych przez nie działań, dzięki czemu podmioty korzystające z certyfikowanych laboratoriów mogą w pełni zaufać otrzymywanym rezultatom [https://www.pca.gov.pl/akredytacja/akredytacja/rola-akredytacji/]. Jedną $\mathrm{z}$ wielu istotnych zalet posiadania

\footnotetext{
${ }^{1}$ Studenckie Koło Naukowe Zarządzania i Ekonomii, Uniwersytet Przyrodniczy w Lublinie, malgorzata.chec@o2.pl

${ }^{2}$ Katedra Energetyki i Środków Transportu, Zakład Logistyki i Zarządzania Przedsiębiorstwem, Wydział Inżynierii Produkcji, Uniwersytet Przyrodniczy w Lublinie, monika.stoma@up.lublin.pl

${ }^{3}$ Katedra Energetyki i Środków Transportu, Zakład Logistyki i Zarządzania Przedsiębiorstwem, Wydział Inżynierii Produkcji, Uniwersytet Przyrodniczy w Lublinie, agnieszka.dudziak@up.lublin.pl
} 
akredytacji jest utrzymanie wysokiego poziomu pracy laboratorium, a także zdobycie renomy na rynku. Potwierdzenie kompetencji laboratoriów jest często niezbędne do wykonywania określonych działań [Michalski 2011].

Celem pracy jest przedstawienie procesu przyznawania akredytacji, ogólny przegląd wymagań, jakie stawia norma PN-EN ISO/IEC 17025 laboratoriom wzorcującym, zbadanie zarówno starszych przepisów zawartych w normie z 2005 r., jak i tych, które obowiązują obecnie, a także przyjrzenie się opcji A i opcji B zarządzania. Ponadto celem pracy jest przedstawienie funkcjonowania laboratorium wzorcującego z certyfikatem akredytacji w praktyce oraz ukazanie korzyści wynikających $\mathrm{z}$ posiadania przez laboratorium certyfikatu na zgodność z analizowaną normą.

\section{Akredytacja w liczbach}

Zgodnie z normą PN-EN ISO/IEC 17025 akredytowane mogą być laboratoria wzorcujące oraz badawcze zachowujące bezstronność, niezależność, posiadające określony sposób zarządzania czy utrzymujące właściwą dokumentację, a także spełniające wiele innych wymagań zawartych w powyższej normie. W Polsce w chwili obecnej działa 1520 laboratoriów badawczych, 16 medycznych oraz 139 laboratoriów wzorujących, certyfikowanych przez Polskie Centrum Akredytacji [https://www.pca.gov.pl/akredytowane-podmioty/akredytacje-aktywne/laboratoriawzorcujace/].

$\mathrm{Na}$ rysunku 1 przedstawiono rozkład udzielonych i aktywnych akredytacji laboratoriom wzorcującym w poszczególnych województwach.

\section{Proces akredytacji laboratoriów wzorcujących}

Uzyskanie certyfikatu zgodności z normą PN-EN ISO/IEC 17025 jest uzależnione od opinii Polskiego Centrum Akredytacji na temat działalności laboratorium. Przed przystąpieniem do procesu mającego na celu zdobycie akredytacji laboratorium musi przygotować swój sposób funkcjonowania, tak aby zostały spełnione wszystkie warunki, jakie zakłada norma. Jednostka, która chce uzyskać certyfikat zgodności z normą, powinna złożyć wniosek o akredytację, wypełnić wymagany formularz oraz dostarczyć informacje o zasobach i działalności, a także uiścić określoną przez przepisy opłatę [DA-01].

Jednym z wymogów, jakie powinna spełnić jednostka ubiegająca się o akredytację, jest określenie zakresu działalności, na który chce uzyskać potwierdzenie swoich kompetencji. W dokumentach powinna podać wielkości, materiały oraz określić, co będzie wzorcować, a także zakres oraz błędy pomiaru. Po złożeniu dokumentów kolejnym krokiem jest ocena jednostki w jej siedzibie oraz innych lokalizacjach zadeklarowanych wcześniej przez laboratorium. Polskie Cen- 


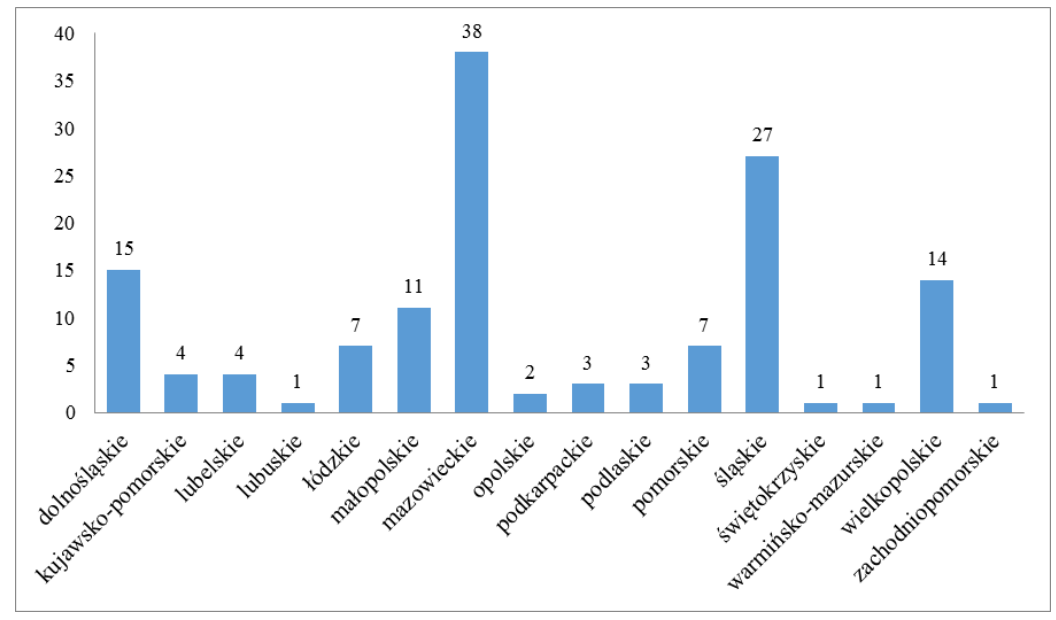

Rys. 1. Liczba akredytowanych laboratoriów wzorcujących w województwach. Źródło: opracowanie własne na podstawie: https:/www.pca.gov.pl/akredytowane-podmioty/akredytacjeaktywne/laboratoria-wzorcujace/ [dostęp: 12.03.2020]

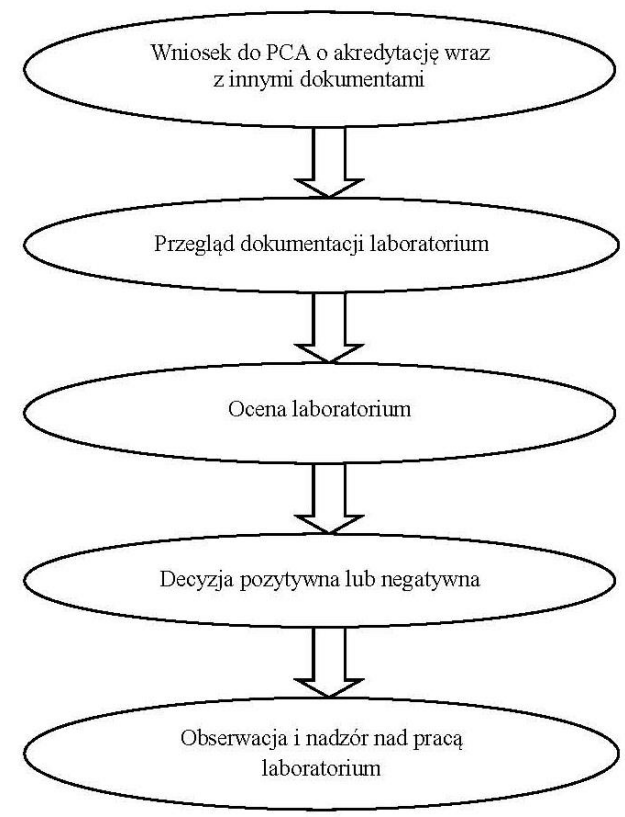

Rys. 2. Schemat udzielania akredytacji wg normy PN-EN ISO/IEC 17025. Źródło: opracowanie własne na podstawie: DA-01 wyd. 10 z 2019-01-24, Opis systemu akredytacji

trum Akredytacji następnie przechodzi do obserwacji mającej na celu sprawdzenie zgodności teorii z praktyką. Odbywa się to m.in. poprzez weryfikację umiejętności personelu oraz sprawdzenie, czy wykonywane wzorcowania są zgodne 
z zadeklarowanymi w dokumentach materiałami, zakresami czy niepewnością pomiarów [DAP-04].

Po uzyskaniu przez laboratorium akredytacji następuje proces nadzoru, a także ponowna ocena. Działania te, przeprowadzane przez Polskie Centrum Akredytacji najczęściej co 2 lata, mają sprawdzić, czy dane laboratorium utrzymuje cały czas jednakowe standardy określone przez normę. Gdy PCA dowiedzie, że dana jednostka nie jest w stanie spełnić wymagań normy PN-EN ISO/IEC 17025, może zawiesić akredytację [DAP-04].

Proces akredytacji laboratoriów wzorcujących zobrazowano na rysunku 2.

\section{Wymagania normy PN-EN ISO/IEC 17025}

Aby Polskie Centrum Akredytacji wydało pozytywną ocenę danego laboratorium, musi ono spełnić szereg wymagań dotyczących zachowania obiektywizmu, struktury organizacyjnej, zasobów i procesów, czy prowadzenia odpowiedniego systemu zarządzania. Przede wszystkim jednostka ta, bez względu na to, czy jest częścią firmy prowadzącej działalność produkcyjną lub handlową, czy jest to laboratorium funkcjonujące niezależnie, musi posiadać osobowość prawną, czyli musi być odpowiedzialna przed prawem za przeprowadzane badania, wzorcowania lub pomiary. Działania te muszą być wykonywane zgodnie z przepisami znajdującymi się w normie PN-EN ISO/IEC 17025. Zarówno kierownictwo, jak i pracownicy nie mogą funkcjonować pod żadnym wpływem politycznym, finansowym lub biznesowym innych osób i firm, tak aby wykonywane przez laboratorium pomiary były jak najbardziej wiarygodne. W przypadku kiedy istnieje zagrożenie dotyczące braku obiektywności jednostka akredytowana jest zobowiązana do możliwie największej minimalizacji lub całkowitego usunięcia tej przeszkody. Wszelkie poufne informacje powinny być odpowiednio chronione. Jednostka wzorcująca należąca do większej firmy nie może mieć konfliktu interesów z macierzystą organizacją, a także musi posiadać odpowiednie miejsce $\mathrm{w}$ przedsiębiorstwie [PN-EN ISO/IEC 17025:2017].

W starszej wersji PN-EN ISO/IEC 17025:2005 można odnaleźć wymagania dotyczące personelu. Dotyczy to konieczności posiadania stanowisk: kierownika laboratorium, kierownika ds. jakości oraz kierownika technicznego i ich zastępców [PN-EN ISO/IEC 17025:2005]. Z kolei w znowelizowanej normie nie widać potrzeby tworzenia tak wielu stanowisk. Zaznaczono jednakże, iż wszyscy pracownicy muszą mieć wykształcenie oraz doświadczenie adekwatne do zajmowanej posady. Każde akredytowane laboratorium musi prowadzić ponadto Księgę jakości, a także inne dokumenty potwierdzające kompetencje danej jednostki [PN-EN ISO/IEC 17025:2017].

Jednym z ważniejszych czynników decydujących o wydaniu akredytacji jest posiadanie dokumentacji, a także odpowiedniego sposobu zarządzania. Zgodnie z obowiązują normą PN-EN ISO/IEC 17025:2017 jednostka certyfikowana na jej podstawie musi dokonać wyboru pomiędzy dwoma systemami zarządzania - opcją 
A oraz opcją B [PN-EN ISO/IEC 17025:2017]. Aby zachować akredytację, laboratoria muszą wprowadzić zmiany do końca listopada 2020 r. [Tugi i Obara 2019].

\section{Opcja A zarządzania laboratorium wzorcującym}

Opcja A jest to zbiór wymagań dotyczących dokumentacji i kontroli nad nią, oceny ryzyka i szans, a także dalszego doskonalenia i korygowania działania laboratorium. Kierownictwo powinno ustalić politykę i cele, zapewniające obiektywne i profesjonalne funkcjonowanie laboratorium. Każdy pracownik musi zostać zapoznany z tymi dokumentami i powinien mieć do nich stały dostęp. Dokumentami mogą być procedury, lecz również podręczniki czy notatki. Aby uzyskać status dokumentu, zgodnie z normą muszą one zostać zaakceptowane, a następnie stale aktualizowane przez uprawnionych do tego pracowników [PN-EN ISO/IEC 17025:2017].

Kolejnym ważnym aspektem dotyczącym zarządzania w opcji A jest ocena ryzyka i szans. Ma to na celu optymalizację działań w laboratorium, tak aby określone przez kierownictwo cele zostały w jak największym stopniu osiągnięte, przy małej liczbie problemów, które uniemożliwią poprawne działanie wybranego systemu zarządzania. Jest to ściśle związane $z$ kolejnym punktem opcji A. Jednostka certyfikowana zgodnie z normą PN-EN ISO/IEC 17025:2017 jest zobowiązana do wprowadzenia systemu doskonalenia. Przede wszystkim firma ta powinna pozyskiwać informacje od klientów na temat ich zadowolenia. Jednym ze sposobów może być zbieranie opinii klientów poprzez ankiety, a następnie wprowadzanie ich sugestii w życie. Doskonalenie pracy pozwala na osiąganie lepszych wyników, a także budowanie zaufania wśród potencjalnych zainteresowanych [PN-EN ISO/IEC 17025:2017].

W przypadku kiedy pojawiają się niespójności czy inne problemy wynikające z popełnianych błędów laboratorium musi je niezwłocznie usunąć, naprawić wynikłe skutki oraz zabezpieczyć się przed popełnieniem ich w przyszłości. Taki sposób postępowania nazwany jest działaniami korygującymi. System ten nie może być jednak stosowany w każdej sytuacji, powinien być dostosowany do indywidualnego przypadku [PN-EN ISO/IEC 17025:2017].

Kolejnymi warunkami są: systematyczna weryfikacja oraz przegląd systemu zarządzania. Ma to na celu sprawdzenie, czy prowadzone działania są zgodne z wymaganiami normy PN-EN ISO/IEC 17025, a także ewentualne skorygowanie pojawiających się niezgodności ze standardami wyznaczonymi przez powyższą normę. Do czynności, jakie laboratorium powinno podjąć, należy m.in. sprawdzenie, czy założone cele są spełnione, prowadzona polityka i przyjęte procedury są aktualne, a wprowadzone działania korygujące zdały egzamin. Jednostka powinna również przejrzeć, jak uzyskane od klientów informacje zostały wykorzystane. Ważnym aspektem jest sprawdzenie, czy wcześniejsze doskonalenie przyniosło oczekiwany efekt [PN-EN ISO/IEC 17025:2017]. 


\section{Opcja B dotycząca zarządzania}

Drugą możliwością sposobu zarządzania, jaką daje znowelizowana norma PN-EN ISO/IEC 17025, jest wybór systemu zgodnego z normą ISO 9001. Wybór tej opcji zakłada także spełnienie standardów dotyczących zarządzania. Wymagania zawarte w normie ISO 9001 obejmują wiele jednostek organizacyjnych i nie są stosowane jedynie w laboratoriach. Norma ISO 9001, podobnie jak PN-EN ISO/IEC 17025, zawiera wymagania dotyczące organizacji i struktury zarządzania, a także celów oraz dokumentacji i doskonalenia, jednak zawiera mniej warunków dotyczących ściśle laboratoriów. Pomimo tego wybór systemu zarządzania zgodnego $\mathrm{z}$ opcją $\mathrm{B}$ jest całkowicie równoznaczny $\mathrm{z}$ wypełnieniem przepisów znajdujących się w normie PN-EN ISO/IEC 17025 [Jędza 2012].

\section{Praktyczny aspekt PN-EN ISO/IEC 17025}

Jedno z laboratoriów wzorcujących znajdujące się na terenie województwa lubelskiego posiada akredytację zgodnie z PN-EN ISO/IEC 17025. Dzięki udostępnionym do badań dokumentom można przyjrzeć się, jak działa akredytowane laboratorium w praktyce. Obecnie jednostka ta funkcjonuje zgodnie $\mathrm{z}$ wymaganiami starszej wersji normy.

Opisywane laboratorium dba o poufność danych klientów dzięki odpowiedniemu zabezpieczaniu tych danych, a przede wszystkim nieudostępnianiu ich osobom trzecim. Jednym $\mathrm{z}$ ważnych działań jest zachowywanie bezstronności dzięki analizowaniu każdej czynność, jaka zostaje podjęta, a może zagrozić brakiem obiektywizmu, kompetencji czy rzetelności. Zgodnie z przepisami, gdy w laboratorium pojawia się zagrożenie tego typu, czynności czy działania nie są podejmowane. Nikt nie może zmieniać wyników wzorcowań czy wprowadzać zmian, które wpływają na uzyskany wynik. Jednym z zastrzeżeń, jakie wprowadziło laboratorium, mającym na celu zabezpieczyć bezstronność, jest niewykonywanie wzorcowań urządzeń, które są naprawiane przez jednostkę.

Firma ta, wychodząc naprzeciw standardom normy PN-EN ISO/IEC 17025, wprowadziła określone w przepisach wymagania dotyczące systemu zarządzania. Zgodnie z wymaganiami zawartymi w powyższej normie wyznaczona została osoba odpowiedzialna przed prawem za wszystkie przedsięwzięcia w laboratorium, jest to właściciel. Jest on zobowiązany wobec normy za wprowadzenie, utrzymanie i doskonalenie sposobu zarząadzania, a także za rzetelność przeprowadzanych w jednostce wzorcowań. Właściciel odpowiada też za politykę i cele, a także za zasoby firmy. Zgodnie z PN-EN ISO/IEC 17025:2005 w tym akredytowanym laboratorium znajdują się stanowiska kierownika laboratorium, kierownika technicznego oraz kierownika ds. jakości, a także ich zastępców. Kierownik laboratorium odpowiada za instrukcje oraz zatwierdzanie świadectw wzorcowań, a także za kontrolę zapisów. Zajmuje się też niezgodnościami, które mogą się pojawić. 
Z kolei kierownik techniczny to osoba, która odpowiada za proces, narzędzia oraz materiały używane podczas wzorcowania. Natomiast kierownik ds. jakości jest zobowiązany do kontrolowania dokumentacji i zapisów, szkolenia personelu, a także analizy zadowolenia wśród klientów. Poza ww. czynnościami każda $z$ tych osób posiada też inne obowiązki. Personel danego laboratorium musi bowiem dokładnie oraz sumiennie, a co za tym idzie profesjonalnie, wykonywać wzorcowania, stosować się do przepisów nie tylko dotyczących akredytacji, ale też bezpieczeństwa i higieny pracy czy innych procedur oraz instrukcji. Wszyscy pracownicy są kontrolowani przez kadrę kierowniczą oraz mają stały dostęp do przepisów dotyczących pracy.

Wprowadzony zgodnie z normą system zarządzania zakłada posiadanie dokumentacji, czyli przede wszystkim Księgę jakości, politykę jakości oraz instrukcje; oprócz tego inne dokumenty i zapisy. W Księdze jakości notowana jest realizacja i zbiór wszystkich przepisów niezbędnych do działania zgodnie z normą PN-EN ISO/IEC 17025:2005. Laboratorium to, spełniając wymogi, musi się stale doskonalić, a także korygować wszelkie niezgodności. Wprowadzone rozwiązanie zakłada znalezienie i zlikwidowanie przyczyny braku zgodności, a następnie jej analizę. Powyższe laboratorium poprzez swoje działania w pełni

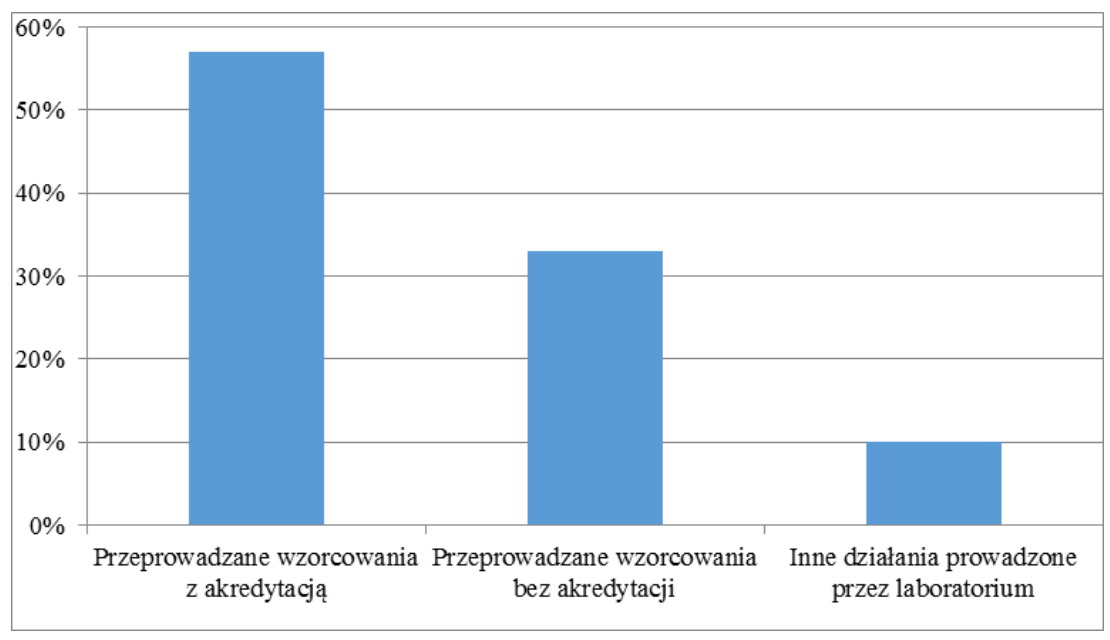

Rys. 3. Działania prowadzone przez laboratorium wzorcujące. Źródło: opracowanie własne na podstawie danych udostępnionych przez określone laboratorium wzorujące

realizuje wymogi normy PN-EN ISO/IEC 17025. Pomimo tego, że działa ono jeszcze zgodnie ze starszą wersją nomy, to przygotowuje się do wprowadzenia znowelizowanego systemu przepisów.

Analizowana firma poza prowadzeniem wzorcowań zgodnie z normą, zajmuje się także innymi usługami, co przedstawia rysunek 3 . 
Aby zachować pełnię obiektywizmu i rzetelności, laboratorium to wprowadziło działania uniemożliwiające wpływ innych usług na poprawne funkcjonowanie i bezstronność firmy.

\section{Korzyści z akredytacji laboratorium}

Prowadzenie działalności certyfikowanej przez normę „Ogólne wymagania dotyczące kompetencji laboratoriów badawczych i wzorcujących" wymaga dostosowania się do przepisów i standardów wynikających z tej normy, ale umożliwia o wiele lepsze działanie firmy, a co za tym idzie jej lepszą pozycję na rynku [Michalski 2011].

Polskie Centrum Akredytacji, udzielając jednostce certyfikacji, potwierdza, że prowadzone w niej wzorowania czy badania są realizowane w sposób w pełni kompetentny. Akredytacja zobowiązuje do szczegółowych udokumentowań przeprowadzanych prac w laboratorium, jednak niezależnie od tego wszystkie działania mogą być prowadzone w sposób szybki i często bardziej efektywny oraz dokładny. Norma PN-EN ISO/IEC 17025:2005 wymaga utworzenia nie do końca funkcjonalnych stanowisk kierowniczych, niemniej w wielu sytuacjach potrzebnych, a także mających na celu ułatwienie pracy poprzez odciążenie kierownika laboratorium czy właściciela. Z kolei wymagane przez podaną normę posiadanie Księgi jakości uściśla i ujednolica dokumentację [PN-EN ISO/IEC 17025:2005].

Jednak w znowelizowanej formie normy nie zauważa się tak wielu formalności. Standardy nowszej wersji normy wymagają wprowadzenia systemu zarządzania zgodnie zopcją A, czyli ściśle według wymagań PN-EN ISO/IEC 17025:2017. Laboratoria mają też możliwość wyboru drugiej opcji B, która obliguje jednostki do dostosowania się do normy ISO 9001. Wybór sposobu zarządzania A lub B jednostki akredytowane podejmują we własnym zakresie wg odrębnych preferencji. Przepisy zobowiązują do wyboru opcji A lub opcji B nie później niż do 30 listopada 2020 roku, jednak wcześniej laboratoria muszą przygotować pracę zgodnie $\mathrm{z}$ jedną $\mathrm{z}$ opcji. Jeśli tego nie zrobią lub uzyskają negatywną ocenę, ich akredytacja zostanie zawieszona [Tugi i Obara 2019].

\section{Wnioski}

Uzyskanie akredytacji jest związane $\mathrm{z}$ dostosowaniem pracy w laboratorium, dokumentów, zasobów czy systemu zarządzania do wymagań określonych w normie. Norma PN-EN ISO/IEC 17025 potwierdza kompetencje, a także ujednolica działanie jednostek akredytowanych w państwach należących do CEN i CENELEC. Prowadzi to do większego zaufania wśród potencjalnych klientów oraz zapewnienia, że wykonywane wzorcowania są na jak najwyższym poziomie. Dzięki akredytacji wiadomo, że przeprowadzane działania w danym laboratorium są w pełni obiektywne, a otrzymane świadectwo wzorcowania nie jest $\mathrm{w}$ jakikolwiek 
sposób zafałszowane, czy to przez brak kompetencji personelu, błędy w zasobach, czy naciski polityczne, finansowe lub biznesowe ze strony innych osób $\mathrm{i}$ instytucji. Jest to zatem kompatybilne $\mathrm{z}$ istniejącym obecnie trendem dbałości o sprawy związane ze zrównoważonym rozwojem, w tym ochroną środowiska.

Norma zawiera wiele wymagań, które mogą wydawać się zbyt trudne do zrealizowania. Jednak pomimo tak wielu przepisów i standardów wyznaczonych przez PN-EN ISO/IEC 17025 są one możliwe do spełnienia, co można zauważyć $\mathrm{w}$ analizowanym laboratorium $\mathrm{z}$ województwa lubelskiego. W wybranym laboratorium odnaleziono rozwiązania wprowadzone po to, aby osiągnąć jak najbardziej bezstronne i godne zaufania wyniki. Można dostrzec, jak funkcjonuje akredytowane laboratorium wzorujące oraz to, jak akredytacja zgodnie z normą PN-EN ISO/IEC $17025 \mathrm{w}$ realny sposób udowadnia kompetencje, rzetelność oraz bezstronność certyfikowanych jednostek.

\section{Bibliografia}

DA-01 wyd. 10 z 2019-01-24. Opis systemu akredytacji.

DAP-04 wyd. 10 z 2019-01-20. Akredytacja laboratoriów wzorcujących.

http://journals.pan.pl/dlibra/publication/113570/edition/98628/content/mozliwosci-integracji-systemowzarzadzania-jakoscia-iso-9001-iso-iec-17025-i-iso-iec-17020-w-jednostkach-inspekcyjnychnadzorujacych-bezpieczenstwo-zywnosci-br-the-possibilities-of-integration-of-qualitymanagement-systems-iso-9001-iso-iec-17020-and-iso-iec-17025-in-inspection-bodies-supervisingthe-safety-of-the-food-jendza-dorota?language $=\mathrm{pl}$ [data dostępu: 20.03.2020].

https://www.pca.gov.pl/akredytacja/akredytacja/rola-akredytacji/ [data dostępu: 16.03.2020].

https://www.pca.gov.pl/akredytowane-podmioty/akredytacje-aktywne/laboratoria-wzorcujace/ [dostęp: 16.03.2020].

https://www.pca.gov.pl/gfx/pca/userfiles/_public/o_pca/dzialania_promocyjne/eurolab2019/eurola b_2019_pdf.pdf [dostęp 16.03.2020].

http://yadda.icm.edu.pl/baztech/element/bwmeta1.element.baztech-article-LOD7-00260006/c/httpwww_bg_utp_edu_plartlab32011akredytacja20laboratorif3w20wg20normy.pdf [data dostępu: 16.03.2020].

Jędza D., 2012. Możliwości integracji systemów zarządzania jakością ISO 9001, ISO/IEC 17025 i ISO/IEC $17020 \mathrm{w}$ jednostkach inspekcyjnych nadzorujących bezpieczeństwo żywności. Organizacja i Kierowanie 1, 95-113.

Michalski R., 2011. Akredytacja laboratoriów wg normy PN-EN ISO/IEC 17025 w pigułce. LAB, rok $16, \mathrm{nr} 3,32-35$.

PN-EN ISO/IEC 17025:2005. Ogólne wymagania dotyczące kompetencji laboratoriów badawczych i wzorcujących.

PN-EN ISO/IEC 17025:2017. Ogólne wymagania dotyczące kompetencji laboratoriów badawczych i wzorcujących.

Tugi H., Obara M., 2019. Doświadczenia z oceny kompetencji laboratoriów w odniesieniu do wymagań normy PN-EN ISO/IEC 17025:2018-02. Polskie Centrum Akredytacji, https://www.pca.gov.pl [data dostępu: 16.03.2020]. 
Aleksandra Chrapek ${ }^{1}$, Katarzyna Dzida ${ }^{2}$

\title{
Skład chemiczny, warunki uprawy i właściwości lecznicze mięty pieprzowej (Mentha $\times$ piperita L.)
}

Chemical composition, growing conditions and healing effects of peppermint (Mentha $\times$ piperita L.)

\begin{abstract}
Wstęp
Mięta pieprzowa (Mentha $\times$ piperita L.) to jedna $\mathrm{z}$ najcenniejszych roślin zielarskich o bardzo szerokim zastosowaniu. Posiada działanie rozkurczowe, moczopędne, pobudzające układ pokarmowy, żółciopędne, wiatropędne, odkażające, kojące, przeciwbólowe, przeciwzapalne i napotne. Surowcami mięty pieprzowej są: ziele (Menthae piperitae herba) oraz liść (Menthae piperitae folium). Surowce zawierają garbniki (6-12\%), flawonoidy, fenolokwasy, gorycze, witaminy i sole mineralne oraz najbardziej znaczący dla surowca olejek eteryczny (Menthae piperitae oleum), w którym głównym składnikiem jest mentol. Ważnymi składnikami olejku są również: menton, pulegon, geraniol, limonen i piperyton. Skład olejku jest zmienny, ze względu na czynniki środowiskowe, zmienność osobniczą i okres zbioru. Zastosowanie tej rośliny nie kończy się na medycynie. Stosuje się ją również w farmacji, kosmetyce i kulinariach. Miętę pieprzową można hodować zarówno w ogrodzie, jak i w pojemnikach. Do uprawy wymaga gleb żyznych, próchniczych, przepuszczalnych, zasobnych w składniki pokarmowe, o $\mathrm{pH}>6$. Najlepszy plon przynosi na czarnoziemach, madach i rędzinach. Plantację zakłada się wyłącznie z sadzonek i użytkuje maksymalnie 3 lata. Termin zbioru surowca jest zależny od wieku plantacji. Najlepszą jakość surowca uzyskuje się z ziela suszonego $\mathrm{w}$ temperaturze $35^{\circ} \mathrm{C}$, z lekkim natężeniem przepływu powietrza. Miętę pieprzową uprawia się na całym świecie, główne obszary uprawy mięty występują w Europie, Ameryce Południowej i Japonii. Mnogość aktywnych substancji biologicznych, szerokie zastosowanie i wyjątkowy aromat sprawiają, że roślina ta jest jedną z najpopularniejszych i najchętniej stosowanych od wieków.
\end{abstract}

\footnotetext{
${ }^{1}$ Studenckie Koło Naukowe Ogrodników, Uniwersytet Przyrodniczy w Lublinie, aleksz1999@gmail.com

${ }^{2}$ Zakład Żywienia Roślin, Instytut Produkcji Ogrodniczej, Wydział Ogrodnictwa i Architektury Krajobrazu, Uniwersytet Przyrodniczy w Lublinie
} 
Celem pracy jest podsumowanie i zaprezentowanie aktualnych informacji na temat zastosowania, właściwości leczniczych i uprawy mięty pieprzowej (Mentha $\times$ piperita $\mathrm{L}$.)

\section{Mięta w ujęciu historycznym}

Mięta to roślina używana w medycynie od starożytnych czasów w różnych krajach świata [Kligler i Chaudhary 2007]. W starożytnym Egipcie wymieniona została w papirusie Ebersa, który pochodzi z XVI wieku p.n.e. Długo wykorzystywana była przy balsamowaniu zwłok, gdyż wyjątkowo mocny zapach olejku eterycznego maskował nieprzyjemną woń ciała. Surowce z mięty w medycynie chińskiej stosowano jako środek leczniczy. Uwieczniona została również w mitologii greckiej, rzymskiej oraz w Torze. W Stowniku mitologii greckiej i rzymskiej [Grimal 1997] opisana została legenda o powstaniu mięty. Nazwa tej rośliny miała wywodzić się od imienia greckiej nimfy - Minte. Była ona jedną z kochanek Hadesa, władcy świata podziemnego. Zazdrosna żona boga - Persefona, prześladowała nimfę, dlatego Hades, aby chronić Minte, zamienił ją w roślinę na górze Triphylos w Bitynii.

Żydzi rozsypywali na podłogach synagog wiele ziół, w których bardzo duże znaczenie odgrywała mięta. Zarówno roślin świeżych, jak i wysuszonych używano w lecznictwie i magii ludowej. Według wierzeń naszych przodków mięta odstraszała złe duchy i chroniła przed piorunami. Obecnie w Polsce w Święto Niepokalanego Serca Najświętszej Maryi Panny w kościele święci się wianki wykonane $\mathrm{z}$ roślin leczniczych. Każdy ma być z innego zioła, przy czym obowiązkowo musi znaleźć się w nich mięta. Po poświęceniu wiesza się je przed wejściem lub w ganku. Mają one zapewnić błogosławieństwo i ochronę przed nieszczęściami. Zwyczaj ten praktykowany jest głównie w regionach wschodniej Polski. Niemiecki benedyktyn Walafridus Strabus - opat klasztoru Reichenau, w dziele pt. Hortulus pisał, że mięta to nieodgadniona roślina: „Kto by mógł wyliczyć w pełni wszystkie moce i nazwy miąt, równie dobrze mógłby powiedzieć, ile ryb pływa w Morzu Czerwonym, ile iskier wyrzuca Etna" [Lis 2012].

\section{Biologia mięty pieprzowej}

Mięta pieprzowa jest rośliną wieloletnią należącą do rodziny jasnotowatych (Lamiaceae). Powstała z gatunków dzikich: mięty zielonej (Mentha spicata) i nadwodnej (Mentha aquatica) [Lis i Góra 2017]. Mięta zielona jest mieszańcem mięty długolistnej (Mentha rotundifolia) i mięty okrągłolistnej (Mentha longifolia), dlatego też mięta pieprzowa jest mieszańcem potrójnym: Mentha longifolia $\times$ Mentha rotundifolia $\times$ Mentha aquatica [Kołodziej 2010]. Pojawiła się koło miejscowości Mitcham w Anglii, tam też została opisana w $1696 \mathrm{r}$. W roku 1721 miętę pieprzową wpisano do rejestru leków stosowanych w Londynie 
[Kleinod 2008]. W obrębie gatunku Mentha × piperita opisano dwie formy, stanowiące filar zarówno uprawowy, jak i leczniczy mięty pieprzowej, są to: forma palescens (biała) oraz forma rubescens nigra (czarna). Cała roślina mięty odmiany białej jest intensywnie zielona. Łodygi i liście odmiany czarnej są ciemnozielone $\mathrm{z}$ fioletowym lub wpadającym $\mathrm{w}$ czerwień odcieniem. Barwa jest spowodowana obecnością antocyjanów. Rośliny z rodzaju Mentha znane są na całym świecie, różnią się budową morfologiczną oraz składem chemicznym. Do najpopularniejszych w Polsce należą: mięta długolistna (Mentha langifolia L.), mięta nadwodna (Mentha aquatica L.), mięta okrągłolistna (Mentha rotundifolia (L.) Huds.), mięta pieprzowa (Mentha piperita L.), mięta polna (Mentha arvensis L.), mięta zielona (Mentha spicata Huds.) oraz Mentha $\times$ gentilis L. [Mirek i in. 2002].

Mięta pieprzowa (Mentha piperita L.) to bylina charakteryzująca się silnym orzeźwiającym zapachem. Wytwarza podziemne kłącze, z którego wyrastają czterokanciaste, nagie lub owłosione, puste w środku łodygi, o wysokości $60-90 \mathrm{~cm}$, od nasady rozgałęzione $i$ gęsto ulistnione. Tworzy rozłogi podziemne i nadziemne. Nadziemne rozłogi składają się z 6-10 $\mathrm{cm}$ węzłów, łatwo ukorzeniają się przy zetknięciu z ziemią. Odmiana biała charakteryzuje się delikatnymi pędami, niezawierającymi antocyjanów. U odmiany czarnej pędy są fioletowonabiegłe. Część podziemna składa się z walcowatych rozłogów, podzielonych na krótkie węzły, z których wyrastają korzenie przybyszowe [Hołubowicz-Kliza 2012]. Zarówno Osińska [2016], jak i Hołubowicz-Kliza [2007, 2012] podają, iż ponad $90 \%$ rozłogów usytuowane jest w wierzchniej warstwie gleby. Liście są ciemnozielone z purpurowym odcieniem (rubescens) lub jasnozielone (pallescens), naprzeciwległe, jajowato podługowate, ogonkowe, nierówno ostro piłkowane, zaostrzone, $\mathrm{z}$ obu stron pokryte gruczołkami olejkowymi, pojawiającymi się w 3-4. tygodniu rozwoju. Według Davis [1993] najlepszy jakościowo olejek otrzymuje się z mięty wyhodowanej na terenie Anglii, czego powodem jest najdogodniejszy, umiarkowany klimat. Liście mięty osiągają długość od 4 do $7 \mathrm{~cm}$. Wszystkie nerwy na górnej stronie blaszki są wgłębione, a na dolnej wypukłe, krótko owłosione, o fioletowoczerwonej barwie. Kwiaty niepozorne, jasnofioletowe, zebrane na szczytach łodyg w kłosy pozorne. Kwitnie od lipca do połowy sierpnia. Wytwarza nieliczne rozłupki, o zdegenerowanych pylnikach, na ogół niekiełkujące, ciemnobrązowe, odwrotnie jajowate. Masa tysiąca niełupek wynosi około $0,065 \mathrm{~g}$. Mięta pieprzowa nie wytwarza żywych nasion, ponieważ jest mieszańcem wielogatunkowym, dzięki czemu rozmnaża się wyłącznie wegetatywnie [Lis i Góra 2017].

\section{Uprawa mięty pieprzowej}

Mięta pieprzowa najlepiej rośnie na glebach żyznych, z dużą zawartością próchnicy oraz składników pokarmowych, o odczynie lekko kwaśnym do obojętnego. Gleba powinna być przepuszczalna. Zauważono [Osińska i Rosłon 
2016], że największy plon uzyskuje się na madach, lessach, rędzinach i czarnoziemach. Należy pamiętać o głębokiej orce jesienią oraz włókowaniu i bronowaniu wiosną. $Z$ pola wymagane jest usunięcie chwastów, zwłaszcza wieloletnich, tworzących kłącza (np. perz właściwy). Plantację zakłada się z sadzonek. Odmiana biała wymaga starannej uprawy, ponieważ posiada niską tolerancję na szkodniki oraz niesprzyjające warunki klimatyczne, natomiast odmiana czarna jest odporniejsza na niesprzyjające warunki klimatyczne oraz szkodniki [Hołubowicz-Kliza 2012]. Cechy te czynią ją dominującą odmianą uprawową zarówno w Polsce, jak i w wielu innych krajach. Plantację zakłada się z rozłogów podziemnych, jak i nadziemnych. Częściej wykorzystuje się rozłogi podziemne. Sadzenie przeprowadza się wiosną. Młode rośliny sadzi się na głębokości $4-5 \mathrm{~cm}$ co $10-15 \mathrm{~cm}$ od siebie. Rzędy powinny być w rozstawie $30-40 \mathrm{~cm}$. Na hektar potrzebne jest 150-200 tys. sadzonek posiadających min. 3 węzły z korzeniami przybyszowymi [Hołubowicz-Kliza 2007].

W celu wzbogacenia gleby w substancję organiczną i składniki pokarmowe rok przed założeniem plantacji należy zastosować obornik (35 ton na hektar). Według Andrzejewskiej i Pisulewskiej [2019] dobre rezultaty daje stosowanie kompostu przed sadzeniem. Jest to szczególnie widoczne na glebach lekkich. Najlepszymi przedplonami w uprawie mięty pieprzowej są rośliny motylkowe i rzepak przyorane na zielony nawóz oraz warzywa na oborniku. Plantację mięty najlepiej użytkować 3 sezony, ponieważ w następnych latach gleba ma coraz gorszą strukturę i zostaje pozbawiana składników pokarmowych. Nawozy organiczne trzeba uzupełnić nawozami mineralnymi w dawkach dostosowanych w zależności od zasobności gleby. Jak podaje Kołodziej [2010], mięta pieprzowa potrzebuje średnio (w kg na ha): $80-120 \mathrm{~N}, 60-80 \mathrm{P}_{2} \mathrm{O}_{5}$ oraz $120-140 \mathrm{~K}_{2} \mathrm{O}$. Fosfor i potas należy uzupełnić przed wsadzeniem roślin, natomiast azot należy rozdzielić na 3 równe części i podać przed sadzeniem, po posadzeniu roślin oraz po zbiorze.

Do walki z chwastami w kraju dopuszczone jest stosowanie herbicydów. Na chwasty jednoliścienne można stosować np. Select Super 120 EC oraz Fusilade Forte 150 EC. Na chwasty dwuliścienne Lentagran 48 WP [Andrzejewska i Pisulewska 2019]. Do najgroźniejszych chorób mięty należą: rdza mięty (Puccinia menthae Pers.), fuzarioza (Fusarium sp.), septorioza (Septoria menthae Qud.) oraz mączniak właściwy (Erysiphe cihoracearum). Szkodnikami plantacji mięty pieprzowej są: pchełki, stonka ziemniaczana, zmienniki, skoczkowate i tarczyk zielony. $\mathrm{Z}$ chwilą pojawienia się szkodników lub stwierdzenia uszkodzeń należy opryskiwać rośliny preparatami zgodnie z aktualnym programem ochrony roślin.

\section{Zbiór i przygotowanie surowca mięty}

Termin zbioru surowca jest zależny od wieku plantacji. Miętę można ścinać ręcznie lub za pomocą kosiarek na wysokości 5-6 cm nad ziemią. Podczas zbioru ręcznego, gdy zbiera się pojedyncze liście, można od razu przeprowadzić 
selekcję, odrzucając te $\mathrm{z}$ wadami lub oznakami choroby. Oprócz selekcji zbiór ręczny pozwala zachować więcej olejków eterycznych, gdyż rośliny nie są narażone na zgniatanie. Na polu miętę zbiera się w kosze, układając cienką warstwę roślin. Surowiec po zebraniu nie może przebywać długo na słońcu, od razu powinien być przeniesiony na miejsca przeznaczone do suszenia. Dłuższa ekspozycja na słońce grozi utratą części olejków oraz barwy liści, co znacznie obniża jakość [Mystkowska i in. 2016]. Pierwszy zbiór na jednorocznych plantacjach ma miejsce, gdy roślina wytworzy pąki, następny (często połowiczny) w miarę rozwoju roślin. W następnych latach pierwszy zbiór przypada na 14 dni przed kwitnieniem (czerwiec-lipiec) a drugi na przełomie sierpnia i września. Liście z pierwszych zbiorów w poszczególnych sezonach są najlepsze, gdyż zawierają najwięcej olejku eterycznego. Ziele wysycha szybko, a najlepszą jakość surowca uzyskuje się podczas suszenia w temperaturze $35^{\circ} \mathrm{C}$, w warstwie $3 \mathrm{~kg} / \mathrm{m}^{2}$ z przepływem powietrza o lekkim natężeniu. Miętę pieprzową uprawia się na całym świecie, jednak absolutnym liderem w produkcji olejku tej rośliny jest USA [Davis 1993, Lis i Góra 2017].

\section{Sklad chemiczny surowca mięty}

Surowcem mięty pieprzowej jest liść (Menthae piperitae folium), a także ziele (Menthae piperitae herba). W surowcach znajdują się: olejki eteryczne, garbniki, flawonoidy, fenolokwasy, gorycze, kwasy organiczne (np. kwas chlorogenowy), fitosterole, witaminy, prowitamina A i sole mineralne, szczególnie żelaza, miedzi, magnezu, sodu, boru, cynku i manganu. Najważniejszą substancją w surowcu mięty pieprzowej jest olejek mięty pieprzowej (Oleum Menthae piperitae). Liście mięty zawierają ok. $2 \%$ olejku [Kałwa i in. 2017], choć wartość ta może sięgać nawet 3,5\% [Senderski 2017]. Jego skład i ilość są zależne od wielu czynników. Najważniejszymi są termin zbioru oraz kondycja rośliny, która jest zależna od warunków klimatycznych i właściwej uprawy. W Ziołolecznictwie pod red. Ożarowskiego [1982] stwierdzono, iż olejek mięty pieprzowej, składa się z ponad 30 składników, wśród których dominują mentol i jego izomery (głównie 1-mentol), stanowiące ponad połowę całej masy olejku. Według analiz Kiełtyki i in. [2018] mięta pieprzowa charakteryzuje się najintensywniejszym, najbardziej orzeźwiającym zapachem, jednak aromat ziołowy jest prawie niewyczuwalny w porównaniu z innymi odmianami mięty. Olejek formy białej w porównaniu z formą czarną mięty uchodzi za subtelniejszy i jest częściej wykorzystywany do produkcji mieszanek ziołowych. Odmiana czarna posiada wyższą zawartość olejku oraz silniejszy zapach. Obok mentolu, wśród dominujących związków, wymienia się jeszcze menton (wraz z izomerami, głównie l-mentonem), stanowiący od $5 \%$ do 35\%, karwon, pulegon, izopulegon, linalol (wraz z jego octanami) oraz piperytenon, piperyton. Mentol jest cyklicznym, nasyconym monoterpenowym alkoholem. Menton, podobnie jak pulegon i piperyton, są ketonami [Grigoleit i Grigoleit 2005, Harris 2006, Kowalski i Wawrzykowski 2009, Lis i Góra 2017]. 


\section{Zastosowanie i właściwości mięty pieprzowej}

Miętę pieprzową stosuje się niemal w każdej dziedzinie życia. Używana jest w kosmetyce, kuchni, przemyśle, ale przede wszystkim w lecznictwie. Od wieków napary z mięty polecane są w dolegliwościach układu trawiennego. Przyjmowana przed posiłkiem wzmaga łaknienie, dlatego jest polecana osobom wykazującym brak apetytu. Jest dobrym środkiem zapobiegającym mdłościom i doskonałym środkiem $\mathrm{w}$ walce $\mathrm{z}$ niestrawnością, ponieważ pobudza wydzielanie soku żołądkowego, przyspieszając oraz ułatwiając trawienie i przyswajanie pokarmu. Jest stosowana $\mathrm{w}$ chorobie jelita drażliwego [Pietrzak i in. 2018]. Działa wiatropędnie, zapobiegając gromadzeniu się gazów i zastojom treści pokarmowej w jelitach, przywracając im prawidłową perystaltykę [Trevisan i in. 2017]. Udowodniono, że mentol wpływa na mechanizm blokowania wapniowych kanałów w błonach komórkowych mięśni gładkich, działając rozkurczowo [Oracz 2019]. Obok mentolu ważnym elementem działającym rozkurczowo są flawonoidy. W chwilach stresu nasz żołądek się kurczy, w wyniku czego denerwujemy się bardziej, mięta pomaga rozluźnić mięśnie gładkie, zwalcza ból, dzięki czemu działa uspokajająco na umysł. Olejek stosowany w aromaterapii również przynosi ukojenie, odprężenie, łagodzi stres, pomaga zwalczyć tzw. huśtawki nastroju. Zapach olejku uzależniony jest głównie od lewoskrętnego izomeru mentolu (1-mentolu), który odpowiada również za uczucie chłodu po zastosowaniu produktów zawierających ten związek, ponieważ drażni zakończenia włókien nerwowych związanych $z$ uczuciem zimna [Wojciechowska $i$ in. 2016]. U dzieci stosowana jest do zwalczania kolek już od pierwszych miesięcy życia. Działa moczopędnie oraz odkażająco na drogi układu moczowego. Mięta pieprzowa jest używana również w schorzeniach dróg żółciowych i wątroby. Jest szczególnie polecana przy zmniejszonym wytwarzaniu żółci oraz zapaleniu pęcherzyka żółciowego. Bywa używana podczas lekkiej niewydolności wątroby oraz przy jej regeneracji. W medycynie niekonwencjonalnej roślinę tę stosuje się do zwalczania kamicy żółciowej. Mięta pieprzowa stanowi składnik leków przeznaczonych do stosowania przy infekcjach górnych dróg oddechowych. Działa wykrztuśnie, ułatwia oddychanie podczas przeziębienia oraz udrażnia nos [Rita i Animesh 2011]. Wykorzystywana jest do inhalacji, zwalcza zapalenie zatok. Wykazuje działanie odkażające i bakteriobójcze. Z badań Kusiak i in. [2010] wynika, iż bakterie Gram-dodatnie były bardziej wrażliwe na olejek z mięty pieprzowej w porównaniu z Gram-ujemnymi. Jest to spowodowane obecnością dużej ilości garbników, takich jak taniny (dobrze rozpuszczalne w wodzie garbniki), które podobnie jak mentol mają działanie przeciwbakteryjne. Najsilniejsze działanie wykazują wobec bakterii tlenowych. Według Klaudel [2006] olejek eteryczny hamuje rozwój bakterii z rodzaju Escherichia coli, Staphylococcus aureus, Pseudomonas aeruginosa, Bacillus subtilis oraz Enterococcus faecalis [Mahboubi i Kazempour 2014]. Badania Adaszyńskiej i in. [2013] potwierdziły również grzybobójcze działanie olejku miętowego. Wrażliwość wykazały szcze- 
py reprezentowane przez grzyby z rodzajów: Candida albicans (naturalny składnik flory bakteryjnej, jednak gdy jest ich nadmiar, układ immunologiczny działa nieprawidłowo), Trichophyton rubrum (odpowiedzialny za grzybicę paznokci) oraz Aspergillus niger (powoduje aspergilozę objawiającą się zapaleniem płuc, alergiami lub problemami natury psychicznej). Dzięki przeciwdrobnoustrojowemu i odświeżającemu działaniu olejek wykorzystywany jest do produkcji past do zębów oraz płynów do płukania jamy ustnej. Jest stosowany zewnętrznie w preparatach antyseptycznych, maściach, żelach oraz w wielu środkach pielęgnacyjnych i w kosmetykach.

\section{Podsumowanie}

Nazwanie mięty pieprzowej uniwersalnym lekiem i remedium na każdą dolegliwość jest w pełni uzasadnione, gdyż znalazła zastosowanie w niemal każdej dziedzinie życia. Mimo że jest uprawiana od dziesięcioleci, nie straciła na popularności, a wręcz przeciwnie, popyt na nią wciąż rośnie. Idealnie komponuje się $\mathrm{z}$ większością aromatów. Stosowana w połączeniu lub jako samodzielny składnik nadaje niesamowity aromat, pobudzając wszystkie zmysły. Obecnie obserwuje się tendencję powrotu do naturalnych metod leczenia. Społeczeństwo coraz większą wagę przywiązuje do zdrowego, ekologicznego stylu życia. Zioła i ziołolecznictwo, mimo że nigdy nie odeszły w zapomnienie, teraz przeżywają swój renesans. Produkty ziołowe są coraz częściej wykorzystywane, a dzięki wszechstronności zastosowania mięta pieprzowa stała się komponentem wielu często używanych preparatów.

\section{Bibliografia}

Adaszyńska M., Swarcewicz M., Markowska-Szczupak A. Jadczak D., 2013. Skład chemiczny i właściwości przeciwdrobnoustrojowe olejku eterycznego i ekstraktu z mięty pieprzowej odmiany 'Asia'. ŻNTJ 2(87), 116-125.

Andrzejewska J., Pisulewska E., 2019. Uprawa roślin zielarskich. Wyd. UTP, Bydgoszcz.

Davis P., 1993. Aromaterapia od A do Z. Wyd. OPUS, Łódź.

Grigoleit H.G., Grigoleit P., 2005. Pharmacology and preclinical pharmacokinetics of peppermint oil. Phytomedicine 12, 612-616.

Grimal P., 1997. Słownik mitologii greckiej i rzymskiej. Ossolineum, Wrocław.

Harris B., 2006. Menthol: a review of its thermoreceptor interactions and their therapeutic applications. Int. J. Aromather. 16, 117-131.

Hołubowicz-Kliza G., 2007. Alternatywna uprawa ziół na ziele i liście. IUNG, Puławy.

Hołubowicz-Kliza G., 2012. Polowa uprawa ziół. IUNG, Puławy.

Kałwa K., Wilczyński K., Olesińska K., 2017. Wpływ warunków przechowywania suszonej mięty pieprzowej (Mentha piperita L.) na antyoksydacyjne właściwości otrzymanych naparów oraz zawartości i składu olejku eterycznego. Acta Sci. Pol., Technica Agraria 16(1-2), 13-22.

Kiełtyka-Dadasiewicz A., Lis K., Kubat-Sikorska A., 2018. Analiza zapachu wybranych odmian mięty (Mentha sp.). Herbalism 1(4), 52-64.

Klaudel L., 2006. Mięta pieprzowa. Panacea 2(15), 8-10. 
Kleinod B., Friedhelm S., 2008. Mięta. Lekarstwo, kosmetyk, przyprawa, praktyczne zastosowanie. Wyd. KDC.

Kligler B., Chaudhary S., 2007. Peppermint oil. Am. Fam. Physician. 75, 1027-1030.

Kołodziej B. (red.), 2010. Uprawa ziół. Poradnik dla plantatorów. PWRiL, Poznań.

Kowalski R., Wawrzykowski J., 2009. Essential oils analysis in dried materials and granulates obtained from Thymus vulgaris L., Salvia officinalis L., Mentha piperita L. and Chamomilla recutita L. Flavour. Fragr. J. 24, 31-35.

Kusiak A., Kędzia A., Molęda-Ciszewska B., Kędzia A.W., Maciejewska K., Włodarkiewicz A., Kwapisz E., 2010. Działanie olejku z mięty pieprzowej na bakterie beztlenowe. Dent. Med. Probl. 47, 3, 334-338.

Lis A., 2012. Najcenniejsze olejki eteryczne. Olejki miętowe. Aromaterapia 2(68), 5-15.

Lis A., Góra J., 2017. Najcenniejsze olejki eteryczne, cz. 1. Wyd. PŁ, Łódź.

Mahboubi M., Kazempour N., 2014. Chemical composition and antimicrobial activity of peppermint (Mentha piperita L.) essential oil. Songklanakarin J. Sci. Technol. 36(1), 83-87.

Mirek Z., Piękoś-Mirkowa H., Zając A., Zając M., 2002. Flowering plants and pteridophytes of Poland. A checklist. Krytyczna lista roślin kwiatowych i paprotników Polski. Biodiv. Pol. 1, 442-445.

Mystkowska I., Zarzecka K., Baranowska A., Gugała M., 2016. Mięta pieprzowa (Mentha piperita L.) - roślina o różnorodnych właściwościach biologicznych i leczniczych. Herbalism, 1(2) 117-127.

Oracz G., 2019. Olejek miętowy - naturalne rozwiązanie na ból brzucha i wzdęcia w szczególności u osób z IBS. Farm. Prakt. 3-4(115), 43-44.

Osińska E., Rosłon W., 2016. Zioła. Uprawa i zastosowanie. Hortpress, Warszawa.

Ożarowski A. (red.), 1982. Ziołolecznictwo. PZWL, Warszawa.

Pietrzak A., Skrzydło-Radomańska B., Mulak A., Lipiński M., Małecka-Panas E., Reguła J., Rydzewska G., 2018. Rekomendacje diagnostyczno-terapeutyczne w zespole jelita nadwrażliwego. Prz. Gastroenterol. 13, 167-196.

Rita P., Animesh D.K., 2011. An updated overview on peppermint (Mentha piperita L.). Int. Res. J. Pharm. 2(8), 1-10.

Trevisan S.C.C., Paes Menezes A.P., Barbalho S.M., Guigue E.L., 2017. Properties of Mentha piperita: a brief review. World J. Pharm. Med. Res. 3(1), 309-313.

Wojciechowska I., Wojciechowska A., Wieszczycka K., 2016. Fitofarmakologia w leczeniu chorób żołądka. Kosmos 63(3), 383-387. 
Paula Ćwiek ${ }^{1}$

\title{
Prozdrowotne wlaściwości wybranych nasion roślin strączkowych
}

\author{
Health benefits of selected legumes
}

\begin{abstract}
Wstęp
W ostatnich latach konsumenci zwracają szczególną uwagę na diety roślinne. Spowodowane jest to coraz większą świadomością społeczeństwa dotyczącą prozdrowotnego wpływu bioaktywnych związków pochodzących z roślin na zdrowie człowieka oraz ograniczeniem spożycia mięsa. Szczególne znaczenie w diecie mają rośliny strączkowe, których wpływ na hamowanie rozwoju chorób cywilizacyjnych został potwierdzony naukowo.

Celem opracowania jest przegląd aktualnej literatury naukowej oraz określenie wielokierunkowego prozdrowotnego działania nasion roślin strączkowych na organizm człowieka.
\end{abstract}

\section{Charakterystyka wybranych nasion roślin strączkowych}

Rośliny strączkowe od wieków stanowiły element żywienia człowieka, a także wykorzystywane były w medycynie ludowej jako produkty wykazujące wielokierunkowe działanie lecznicze. Rośliny te należą do grupy roślin jednorocznych $\mathrm{z}$ rodziny motylkowych Fabaceae. Ich częścią jadalną są owoce, czyli tzw. strąki, które spożywa się w całości bądź częściowo w zależności od gatunku i stopnia dojrzałości owoców [Górnicka i in. 2011, Wawryka i Zdrojewicz 2016].

Do jadalnych gatunków strączkowych zalicza się fasolę, groch, orzech ziemny, ciecierzycę, soczewicę, bób oraz soję. W Polsce największą popularnością wśród konsumentów od zawsze cieszyły się fasola, groch, bób i soja. Natomiast w ostatnim czasie wzrosło zainteresowanie Polaków ciecierzycą i soczewicą, co może być spowodowane aktualnym trendem żywieniowym, jakim są diety bezmięsne [Górnicka i in. 2011, Wawryka i Zdrojewicz 2016]. Niestety, mimo zwiększającej się świadomości Polaków na temat wysokich walorów prozdrowotnych roślin strączkowych, w ostatnich latach obserwuje się spadek spożycia tej grupy produktów [Wawryka i Zdrojewicz 2016].

\footnotetext{
${ }^{1}$ Szkoła Doktorska „Produkcja żywności o podwyższonych walorach prozdrowotnych”, Wydział Nauk o Żywności i Biotechnologii, Uniwersytet Przyrodniczy w Lublinie, paula.cwiek@up.lublin.pl
} 
Nasiona roślin strączkowych charakteryzują się wysoką wartością odżywczą. $\mathrm{Na}$ tle innych roślin wyróżniają się dość wysoką zawartością białka wynoszaca średnio od $20 \%$ do $35 \%$ w zależności od rodzaju, warunków uprawy i stopnia dojrzałości owoców. Białko pochodzące z nasion roślin strączkowych zawiera jednak małą ilość aminokwasów siarkowych, w szczególności metioniny i cysteiny, przez co uznawane jest za mniej wartościowe w porównaniu do białka pochodzenia zwierzęcego. W celu poprawy profilu aminokwasów i uzyskania pełnowartościowego białka nasiona roślin strączkowych warto połączyć z ziarnami zbóż, które uzupełnią brakujące aminokwasy [Caire-Juvera i in. 2013]. Należy zauważyć, iż nasiona roślin strączkowych są bogatym źródłem błonnika pokarmowego, witamin, składników mineralnych, takich jak magnez, żelazo, cynk, potas, fosfor oraz związków o wysokim potencjale antyoksydacyjnym [Górnicka i in. 2011].

\section{Wlaściwości prozdrowotne nasion roślin strączkowych}

Do najważniejszych właściwości roślin strączkowych, które mogą wspomóc profilaktykę oraz leczenie niektórych chorób można zaliczyć: działanie przeciwcukrzycowe, przeciwnowotworowe, hipotensyjne, hipocholesterolemiczne oraz antyoksydacyjne. Ponadto dieta bogata w rośliny strączkowe usprawnia pracę jelit oraz wpływa korzystnie na gospodarkę hormonalną kobiet [Wang i in. 2013, Kim i in. 2016, Wawryka i Zdrojewicz 2016, Becerra-Tomas i in. 2018].

\section{Wspomaganie leczenia otyłości}

Problem nadmiernej masy ciała, jakim jest nadwaga i otyłość, dotyka około 1,9 mld osób na świecie, przy czym w 2014 roku z tego powodu zmarło prawie 3,4 mln osób. Niestety, mimo wielu akcji profilaktycznych i edukacyjnych liczba osób $\mathrm{z}$ nadwagą i otyłością $\mathrm{w}$ dalszym ciągu wzrasta i problem ten dotyczy również dzieci. Otyłość jest jednym z czynników zwiększających ryzyko wystąpienia wielu chorób (dokładny ich wykaz przedstawiono w tabeli 1). W związku z tym Światowa Organizacja Zdrowia (WHO, ang. World Health Organization) uznała otyłość za chorobę, która stanowi światową epidemię XXI wieku [Wąsowski i in. 2013, Brończyk-Puzoń i in. 2014, Gajewska i in. 2015].

W celu zmniejszenia i/lub uniknięcia konsekwencji zdrowotnych, jakie niosą za sobą nadwaga i otyłość, zaleca się obniżenie nadmiernej masy ciała poprzez włączenie aktywności fizycznej oraz prawidłowo zbilansowanej diety redukcyjnej [Gajewska i in. 2015]. Korzyści w tym zakresie może przynieść dietoterapia uwzględniająca włączenie do jadłospisu pacjenta nasion roślin strączkowych. Z uwagi na fakt, iż cechują się wysokim indeksem sytości (IS) spożycie posiłku z udziałem tych roślin daje długotrwałe uczucie sytości. Efekt ten może pomóc kontrolować chęć podjadania i ułatwić postępowanie zgodnie z założonymi zaleceniami dietetycznymi [McCrory i in. 2010]. Ponadto w metaanalizie 21 badań klinicznych wykazano, że spożywanie średnio $130 \mathrm{~g}$ nasion roślin strączkowych każdego 
dnia sprzyja kontrolowanej utracie masy ciała [Kim i in. 2016]. Natomiast Papanikolaou i Fulgoni [2008] zaobserwowali, że osoby spożywające regularnie fasolę $\mathrm{w}$ porównaniu $\mathrm{z}$ osobami niespożywającymi tej rośliny, miały mniejszą masę ciała i mniejszy rozmiar talii oraz cechowały się o $22 \%$ mniejszym ryzykiem wystąpienia otyłości. Dodatkowo zauważono, że spożywanie fasolki po bretońsku wiąże się z niższym skurczowym ciśnieniem krwi.

Tabela 1. Zwiększenie ryzyka występowania chorób u osób otyłych w porównaniu z osobami szczupłymi [Gajewska i in. 2015]

\begin{tabular}{|l|l|l|}
\hline \multicolumn{1}{|c|}{ Ponad 3-krotnie } & \multicolumn{1}{|c|}{ 2-3-krotnie } & \multicolumn{1}{c|}{ 1-2-krotnie } \\
\hline $\begin{array}{l}\text { cukrzyca typu 2 } \\
\text { nadciśnienie tętnicze } \\
\text { dyslipidemia } \\
\text { choroby pęcherzyka żółcio- } \\
\text { wego }\end{array}$ & $\begin{array}{l}\text { choroba niedokrwienna } \\
\text { serca } \\
\text { choroba zwyrodnieniowa } \\
\text { stawów (kolan) } \\
\text { hiperurykemia i dna } \\
\begin{array}{l}\text { zadyszka } \\
\text { zespół obturacyjnego bezde- } \\
\text { chu sennego }\end{array}\end{array}$ & $\begin{array}{l}\text { rak (piersi u kobiet po menopau- } \\
\text { zie, okrężnicy, endometrium) } \\
\text { zaburzenia hormonalne } \\
\text { zespół policystycznych jajników } \\
\text { upośledzenie płodności } \\
\text { bóle krzyża } \\
\text { zwiększone ryzyko powikłań } \\
\text { okołooperacyjnych } \\
\text { zaburzenia rozwoju płodu }\end{array}$ \\
\hline
\end{tabular}

Nasiona roślin strączkowych są także źródłem bioaktywnych związków będących inhibitorami lipazy trzustkowej. Mechanizm ich działania polega na zmniejszeniu wchłaniania lipidów z układu pokarmowego, co może okazać się skutecznym sposobem zapobiegania powstawaniu otyłości oraz wspomagania jej leczenia [Jawed i in. 2018]. Natomiast za właściwości obniżające ciśnienie krwi mogą być odpowiedzialne inhibitory ACE (enzym konwertujący angiotensynę I) [Walther i Sieber 2011].

\section{Właściwości przeciwcukrzycowe}

Polskie Towarzystwo Diabetologiczne [Gumprecht 2018] w celach dietoterapii cukrzycy typu 2 zaleca opieranie diety osób chorych przede wszystkim na produktach o niskim indeksie glikemicznym ( $\mathrm{IG}<55)$. Można do nich zaliczyć nasiona roślin strączkowych, które dodatkowo charakteryzują się wysoką zawartością włókna pokarmowego, którego jedną z funkcji jest obniżenie poposiłkowego stężenia glukozy we krwi i/lub obniżenie poziomu insuliny [Jarosz 2017].

Moravek i in. [2018] w swoim badaniu dowiedli, że zastąpienie połowy porcji ryżu i ziemniaków (produkty o wysokim IG) soczewicą (o niskim IG) przyczyniło się do spadku stężenia glukozy we krwi o 20\% w przypadku zastąpienia ryżu i o $35 \%$ w przypadku zastąpienia ziemniaków. Natomiast Jenkins i in. [2012] przeprowadzili randomizowane badanie z udziałem 121 osób chorych na cukrzycę typu 2, których losowo przydzielono do grupy spożywającej co najmniej 1 filiżankę nasion roślin strączkowych dziennie bądź do grupy stosującej dietę ze zwiększoną ilością nierozpuszczalnych frakcji błonnika pochodzących z produktów pełnoziarnistych. Po 3 miesiącach porównano wyniki badanych. 
Okazało się, że obie diety wpłynęły na zmniejszenie wartości hemoglobiny glikowanej u pacjentów z cukrzycą typu 2, przy czym lepsze efekty dała dieta bogata $\mathrm{w}$ nasiona roślin strączkowych $(\mathrm{p}<0,001)$. Wyniki prospektywnego badania PREDIMED opublikowanego w 2018 r. na łamach czasopisma „Clinical Nutrition" również wskazują, że wysokie spożycie nasion roślin strączkowych, głównie soczewicy, zmniejsza o 33\% ryzyko zachorowania na cukrzycę typu 2 [Becerra-Tomas i in. 2018].

Przypuszcza się, że za właściwości przeciwcukrzycowe nasion roślin strączkowych w głównej mierze odpowiada niski indeks glikemiczny oraz wysoka zawartość włókna pokarmowego. Istnieją także badania mówiące o tym, że rośliny strączkowe zawierają substancje mające zdolność hamowania enzymów biorących udział $\mathrm{w}$ absorbcji glukozy w przewodzie pokarmowym [Moravek i in. 2018]. Do substancji o działaniu hipoglikemicznym można zaliczyć m.in. bioaktywne peptydy będące inhibitorami $\alpha$-amylazy i $\alpha$-glukozydazy, które zmniejszają wchłanianie glukozy z przewodu pokarmowego [Yao i in. 2012, Ngoh i Gan 2016]. W celu określenia dokładnego mechanizmu oddziaływania nasion roślin strączkowych na gospodarkę węglowodanową człowieka niezbędne są dalsze badania.

\section{Profilaktyka i wspomaganie leczenia chorób układu krążenia}

Według Europejskiego Urzędu Statystycznego [EUS 2016] choroby układu krążenia i nowotwory złośliwe są najczęstszymi przyczynami zgonów w krajach Unii Europejskiej. Do najważniejszych przyczyn wystąpienia udaru mózgu, niewydolności serca czy zawału mięśnia sercowego należą: nadciśnienie tętnicze, miażdżyca, wysoki poziom cholesterolu oraz brak aktywności fizycznej i nieprawidłowo zbilansowana dieta [Jankowski 2017]. W związku z tym zaleca się, aby osoby znajdujące się $\mathrm{w}$ grupie ryzyka oraz osoby cierpiące $\mathrm{z}$ powodu chorób układu sercowo-naczyniowego stosowały dietę opierającą się na zasadach diety śródziemnomorskiej, która bazuje na dużej ilości warzyw, roślin strączkowych, ryb oraz olejów roślinnych, głównie oliwy z oliwek [Polak i in. 2015, Jankowski 2017].

W metaanalizie przeprowadzonej przez Marventano i in. [2017] obejmującej 14 badań kohortowych wykazano, że spożycie roślin strączkowych wiąże się z niższym ryzykiem wystąpienia chorób układu krążenia, w tym choroby niedokrwiennej serca. Wnioski te potwierdzają wyniki metaanalizy autorstwa Afshin i in. [2014], którzy ocenili, że spożywanie 4 razy w tygodniu posiłków zawierających co najmniej $100 \mathrm{~g}$ nasion roślin strączkowych zmniejsza o $14 \%$ ryzyko wystąpienia choroby niedokrwiennej serca. Ponadto w metaanalizie randomizowanych badań kontrolowanych dowiedziono, że spożywanie roślin strączkowych innych niż soja obniża całkowity poziom cholesterolu w surowicy oraz może obniżać poziom frakcji LDL we krwi [Bazzano i in. 2011]. 


\section{Działanie przeciwnowotworowe}

Choroby nowotworowe wraz z chorobami układu krążenia stanowią główną przyczynę zgonów w krajach Unii Europejskiej [EUS 2016]. Do czynników sprzyjających ich rozwojowi można zaliczyć: palenie tytoniu, niewłaściwą dietę, otyłość, nadmierne spożywanie napojów alkoholowych oraz czynniki genetyczne [Wąsowski i in. 2013]. W celu prewencji chorób nowotworowych zaleca się zmianę dotychczasowego stylu życia uwzględniającą zmianę nawyków żywieniowych oraz włączenie do diety produktów o wysokim potencjale przeciwutleniającym.

W metaanalizie Zhong i in. [2018] opublikowanej na łamach czasopisma ,Journal of Academy of the Nutrition and Dietetics" autorzy zauważyli, że wysoka podaż izoflawonów zawartych w soi i innych roślinach strączkowych pozytywnie korelowała ze zmniejszeniem ryzyka występowania raka endometrium u kobiet. Wyniki kolejnej metaanalizy wskazują, że wyższe spożycie roślin strączkowych znacznie zmniejsza ryzyko wystąpienia gruczolaka jelita grubego [Wang i in. 2013]. Przeprowadzono także metaanalizę prospektywnych badań kohortowych mającą na celu określenie zależności między spożyciem nasion roślin strączkowych, a występowaniem nowotworu prostaty. Otrzymano zaskakujące wyniki, które wykazują, że ryzyko rozwoju raka gruczołu krokowego zmniejsza się o 3,7\% na każde $20 \mathrm{~g}$ dziennego przyrostu spożycia roślin strączkowych [Li i Mao 2017].

Istnieją publikacje naukowe mówiące, że za właściwości przeciwnowotworowe roślin strączkowych, oprócz związków przeciwutleniających (głównie flawonoidów) i błonnika pokarmowego, odpowiadają także związki wpływające na zachowanie homeostazy tkankowych enzymów proteolitycznych oraz inhibitorów proteaz odgrywających rolę w tworzeniu komórek nowotworowych raka piersi, wątroby oraz jelita [Wawryniak i Zdrojewicz 2016, Li i Mao 2017].

\section{Pozostałe właściwości prozdrowotne nasion roślin strączkowych}

Wspomaganie leczenia zespołu policystycznych jajników. Zespół policystycznych jajników (PCOS) jest jedną z najczęściej występujących endokrynopatii wśród kobiet w wieku rozrodczym. Jak sama nazwa wskazuje, jest to zespół schorzeń diagnozowany na podstawie kryteriów rotterdamskich, które obejmują brak lub oligoowulację, kliniczne objawy hiperandrogenizmu i obraz wielotorbielowatych jajników w badaniu USG [Johnstone i in. 2010]. Kobiety z zespołem policystycznych jajników bardzo często wykazują zaburzenia gospodarki węglowodanowej i/lub lipidowej, które są składowymi zespołu metabolicznego [Kazemi i in. 2018].

W 2018 r. w czasopiśmie „Nutrients” zostały opublikowane wyniki randomizowanego badania kontrolnego $\mathrm{z}$ udziałem kobiet $\mathrm{z}$ zespołem policystycznych jajników, które miało na celu porównanie wpływu diety bogatej w nasiona roślin strączkowych i diety TLC (ang. terapeutic lifestyle changes) na parametry kardiometaboliczne. Uczestniczki badania zostały podzielone na 2 grupy - grupę stosującą dietę bogatą w strączki (dziennie kobiety spożywały $150 \mathrm{~g}$ soczewicy 
lub 90 g grochu łuskanego lub $225 \mathrm{~g}$ ciecierzycy bądź fasoli) i grupę stosującą dietę TLC. Po zakończeniu badania autorzy otrzymali interesujące wyniki. W grupie kobiet stosujących dietę zawierającą rośliny strączkowe zaobserwowano $\mathrm{w}$ porównaniu $\mathrm{z}$ grupą stosującą dietę TLC znaczne obniżenie rozkurczowego ciśnienia krwi, zmniejszenie stężenia trójglicerydów oraz lipoprotein frakcji LDL przy jednoczesnym wzroście lipoprotein frakcji HDL oraz zmniejszenie całkowitego pola powierzchni pod krzywą odpowiedzi insulinowej w doustnym teście tolerancji glukozy [Kazemi i in. 2018]. Wyniki tego badania wskazują, że wprowadzenie roślin strączkowych do codziennego jadłospisu kobiet z PCOS może przyczynić się do poprawy parametrów biochemicznych oraz jakości życia tej grupy kobiet.

Regulacja funkcjonowania przewodu pokarmowego. Rośliny strączkowe są doskonałym źródłem błonnika pokarmowego. Według zaleceń WHO osoba dorosła w ciągu doby powinna dostarczyć do swojego organizmu od 20 do $40 \mathrm{~g}$ włókna pokarmowego. Spożywając $100 \mathrm{~g}$ nasion roślin strączkowych dziennie, dostarczane jest ok. $16 \mathrm{~g}$ błonnika, co stanowi 80\% minimalnego dziennego zapotrzebowania [Wawryka i Zdrojewicz 2016]. Błonnik pokarmowy pełni kilka ważnych funkcji w organizmie człowieka. Można zaliczyć do nich regulację gospodarki lipidowej i węglowodanowej oraz usprawnienie pracy przewodu pokarmowego. Błonnik dzięki wysokim zdolnościom wiązania wody zwiększa objętość stolca, co zapobiega występowaniu zaparć. Ponadto przyspiesza perystaltykę jelit oraz wykazuje działanie prebiotyczne, korzystnie oddziałując na florę bakteryjną jelit [Wawryka i Zdrojewicz 2016, Jarosz 2017].

Regulacja gospodarki hormonalnej u kobiet. Nasiona roślin strączkowych charakteryzują się wysoką zawartością fitoestrogenów, do których można zaliczyć izoflawony. To właśnie te związki w głównej mierze odpowiadają za wspomaganie regulacji kobiecej gospodarki hormonalnej (szczególnie w okresie przekwitania) oraz ochronę przed rozwojem nowotworów hormonozależnych, takich jak rak endometrium i rak piersi. Związki te w okresie menopauzalnym wpływają korzystnie również na regulację wapniowo-fosforanową oraz zapobiegają utracie masy kostnej [Wawryka i Zdrojewicz 2016].

\section{Podsumowanie}

Nasiona roślin strączkowych cechują się wysoką wartością odżywczą i wieloma właściwościami prozdrowotnymi. W związku z wysoką zawartością białka w połączeniu z ziarnami zbóż z powodzeniem mogą zastąpić produkty mięsne, które ostatnio coraz częściej są ograniczane bądź eliminowane w dietach Polaków. Rośliny strączkowe, w tym fasola, soczewica, ciecierzyca i groch, z uwagi na różnorodność korzyści płynących z ich spożywania, powinny zostać włączo- 
ne do diety każdego człowieka. Szczególną uwagę na prawidłową podaż tych roślin $\mathrm{w}$ diecie powinny zwrócić osoby cierpiące $\mathrm{z}$ powodu otyłości, cukrzycy typu 2, chorób układu krążenia, zespołu policystycznych jajników oraz osoby będące w grupie zwiększonego ryzyka wystąpienia chorób nowotworowych.

\section{Bibliografia}

Afshin A., Micha R., Khatibzadeh S., Mozaffarian D., 2014. Consumption of nuts and legumes and risk of incident ischemic heart disease, stroke, and diabetes: a systematic review and meta-analysis. Am. J. Clin. Nutr. 100(1), 278-288. https://doi.org/10.3945/ajcn.113.076901

Bazzano L.A., 2011. Non-soy legume consumption lowers cholesterol levels: a meta-analysis of randomized controlled trials. Nutr. Metab. Cardiovasc. Dis. 21(2), 94-103. https://dx.doi.org/10.1016\%2Fj.numecd.2009.08.012

Becerra-Tomas N., Diaz-Lopez A., Rosique-Estaban N., Ros E., Buil-Cosiales P., Corella D., Estruch R., Fito M., Serra-Majem L., Aros F., Lamuela-Raventos R.S., Fiol M., SantosLozano J.M., Diez-Espino J., Portoles O., Salas-Salvado J., 2018. Legume consumption is inversely associated with type 2 diabetes incidence in adults: A prospective assessment from the PREDIMED study. Clin. Nutr. 37(3), 906-913. https://doi.org/10.1016/j.clnu.2017.03.015

Brończyk-Puzoń A., Koszowska A., Nowak J., Dittfeld A., Bieniek J., 2014. Epidemiologia otyłości na świecie i w Polsce. Forum Zab. Metab. 5(1), 1-5.

Caire-Juvera G., Vazquez-Ortiz F.A., Grijalva-Haro M.I., 2013. Amino acid composition, score and in vitro protein digestibility of foods community consumed in Northwest Mexico. Nutr. Hosp. 28(2), 365-371. https://doi.org/10.3305/nh.2013.28.2.6219

Europejski Urząd Statystyczny, 2016. Dane dotyczące przyczyn zgonu. https://ec.europa.eu/eurostat/statistics-explained/index.php?title=Causes_of_death_statistics /pl\#G.C5.82.C3.B3wne ustalenia statystyczne [data dostępu: 18.03.2020].

Gajewska D., Myszkowska-Ryciak J., Lange E., Gudej S., Pałkowska-Goździk E., Bronkowska M., Piekło B., Łuszczki E., Kret M., Białek-Dratwa A., Pachocka L., Sobczak-Czynsz A., 2015. Standardy leczenia dietetycznego otyłości prostej u osób dorosłych. Stanowisko Polskiego Towarzystwa Dietetyki 2015. Dietetyka t. 8, wyd. spec.

Górnicka M., Pierzynowska J., Wiśniewska M., Frąckiewicz J., 2011. Analiza spożycia suchych nasion roślin strączkowych w latach 1999-2008 w Polsce. Bromat. Chem. Toksykol. 44(4), 1034-1038.

Gumprecht J. (red.), 2018. 2018 Guidelines on the management of diabetic patients. A position of Diabetes Poland. Clin. Diabetol. 7, 1. DOI: 10.5603/DK.2018.0001

Jankowski P., 2017. Zasady profilaktyki chorób układu krążenia w 2018 roku. Kardiol. Inwazyjna 12(6), 42-48.

Jarosz M., 2017. Normy żywienia dla populacji polskiej: nowelizacja. IŻŻ, Warszawa.

Jawed A., Singh G., Kohli S., Sumera A., Haque S., Prasad R., Paul D.K., 2018. Therapeutic role of lipases and lipase inhibitors derived from natural resources from remedies against metabolic disorders andl lifestyle diseases. S. Afr. J. Bot. 120, 25-32. https://doi.org/10.1016/j.sajb.2018.04.004

Jenkins D.J.A., Kendall C.W.C., Augustin L.S.A., Mitchell S., Sahye-Pudaruth S., Blanco-Mejia S., Chiavaroli L., Mirrahimi A., Ireland Ch., Bashyam B., Vidgen E., Souza R.J., Sievenpiper J.L., Coveney J., Leiter L.A., Josse R.G., 2012. Effect of legumes as part of a low glycemic index diet on glycemic control and cardiovascular risk factors in type 2 diabetes mellitus: a randomized controlled trial. Arch. Intern. Med. 172(21), 1653-1660, https://doi:10.1001/2013.jamainternmed.70

Johnstone E.B., 2010. The polycystic ovary post-Rotterdam: a common, age-dependent finding in ovulatory women without metabolic significance. J. Clin. Endocrinol. Metab. 95(11), 4965-4972. https://doi.org/10.1210/jc.2010-0202 
Kazemi M., McBreairty L.E., Chizen D.R., Pierson R.A., Chilibeck P.D., Zello G.A., 2018. A comparison of a pulse-based diet and the therapeutic lifestyle changes diet in combination with exercise and health counselling on the cardio-metabolic risk profile in women with polycystic ovary syndrome: a randomized controlled trial. Nutrients 10(10), 1387. https://doi.org/10.3390/nu10101387

Kim S.J., Souza R.J., Choo V.L., Ha V., Cozma A.I., Chiavaroli L., Mirrahimi A., Blanco-Mejia S., Di Buono M., Bernstein A.M., Leiter L.A., Kris-Etherton P.M., Vuksan V., Beyene J., Kendall C.W.C., Jenkins D.J., Sievenpiper J.L., 2016. Effects of dietary pulse consumption on body weight: a systematic review and meta-analysis of randomized controlled trials. Am. J. Clin. Nutr. 103(5), 1213-1223. https://doi.org/10.3945/ajcn.115.124677

Li J., Mao Q.Q., 2017. Legume intake and risk of prostate cancer: a meta-analysis of prospective cohort studies. Oncotarget 8(27), 44776-44784. https://doi.org/10.18632/oncotarget.16794

McCrory M.A., Hamaker B.R., Lovejoy J.C., Eichelsdoerfer P.E., 2010. Pulse consumption, satiety, and weight management. Adv. Nutr. An. Int. Rev. J. 1(1), 17-30. https://dx.doi.org/10.3945\%2Fan.110.1006

Moravek D., Duncan A.M., VanderSluis L.B., Turkstra S.J., Rogers E.J., Wilson J.M., Hawke A., Ramdath D.D., 2018. Carbohydrate replacement of rice or potato with lentils reduces the postprandial glycemic response in healthy adults in an acute, randomized, crossover trial. J. Nutr. 148(4), 535-541, https://doi.org/10.1093/jn/nxy018

Ngoh Y-Y., Gan C-Y., 2016. Enzyme-assisted extraction and identfication of antioxidative and $\alpha$-amylase inhibitory peptides from Pinto beans (Phaseolus vulgaris cv. Pinto). Food Chem. 190, 331-337. http://dx.doi.org/10.1016/j.foodchem.2015.05.120

Papanikolaou Y., Fulgoni V.L., 2008. Bean consumption is associated with greater nutrient intake, reduced systolic blood pressure, lower body weight, and a smaller waist circumference in adults: results from the National Health and Nutrition Examination Survey 1999-2002. J. Am. Coll. Nutr. 27, 569-576. https://doi.org/10.1080/07315724.2008.10719740

Polak R., Philips E.M., Campbell A., 2015. Legumes: health benefits and culinary approaches to increase intake. Clin. Diabetes 33(4), 198-205, https://doi.org/10.2337/diaclin.33.4.198

Walther B., Sieber R., 2011. Bioactive proteins and peptides in foods. Int. J. Vitam. Nutr. Res. 81(23), 181-192. https://doi.org/10.1024/0300-9831/a000054

Wang Y., Wang Z., Fu L., Chen Y., Fang J., 2013. Legume consumption and colorectal adenoma risk: a meta-analysis of observational studies. PLoS One 8(6), e67335. https://dx.doi.org/10.1371\%2Fjournal.pone.00 67335

Wąsowski M., Walicka M., Marcinowska-Suchowierska E., 2013. Otyłość - definicja, epidemiologia, patogeneza. Post. Nauk Med. 26(4), 301-306.

Wawryka J., Zdrojewicz Z., 2016. Fasola - ważny składnik zdrowej diety. Analiza wartości odżywczych. Pediatr. Med. Rodz. 12(4), 394-403. DOI: 10.15557/PiMR.2016.0039

Yao X., Zhu L., Chen Y., Tian J., Wang Y., 2012. In vivo and in vitro antioxidant activity and $\alpha$-glucosidase, $\alpha$-amylase inhibitory effects of flavonoids from Cichorium glandulosum seeds. Food Chem. 139, 59-66. http://dx.doi.org/10.1016/j.foodchem.2012.12.045

Zhong X.S., Ge J., Chen S.W., Xiong Y.Q., Ma S.J., Chen Q., 2018. Association between dietary isoflavones in soy and legumes and endometrial cancer: a systematic review and metaanalysis. J. Acad. Nutr. Diet. 118(4), 637-651. https://doi.org/10.1016/j.jand.2016.09.036 
Oliwia Łopatniuk ${ }^{1}$, Dominika Krakowiak ${ }^{1}$, Damian Laszczka ${ }^{1}$, Natalia Flak ${ }^{1}$, Karolina Dobrosz ${ }^{1}$, Justyna Bohacz $\mathbb{D}^{2}$

\title{
Liczebność mikroorganizmów oraz aktywność enzymów hydrolitycznych pleśni wyizolowanych $\mathrm{z}$ wybranych przypraw dostępnych na rynku krajowym
}

\begin{abstract}
The number of microorganisms and activity of hydrolytic enzymes of molds isolated from selected
\end{abstract} spices available on the domestic market

\begin{abstract}
Wstęp
Przyprawy znalazły zastosowanie na całym świecie m.in. jako dodatki do żywności i są stosowane w celu poprawienia smaku i zapachu potraw. Są stosowane w postaci świeżej, mrożonej, wysuszonej oraz mogą być używane w całości lub w formie rozdrobnionej. Najczęściej wykorzystywany podział przypraw opiera się na trzech głównych kryteriach: przyprawy ziołowe, korzenne i warzywne [Makała 2010a].

Przyprawy zawierają znikome ilości białka, thuszczu i węglowodanów [Ceylan i Fung 2007]. Są źródłem witamin, takich jak karoten, tiamina, ryboflawina i niacyna, oraz pierwiastków, wśród których znajdują się przede wszystkim wapń, magnez, mangan, fosfor, potas, chlor, miedź, żelazo, cynk i sód. Wiele przypraw zawiera składniki chemiczne, które są cenione za działanie przeciwutleniające, antyseptyczne oraz zmniejszające indukcję i rozwój komórek nowotworowych [Makała 2010b].

Przyprawy są dobrym środowiskiem do rozwoju różnorodnych mikroorganizmów, co często wpływa na ich jakość. Wśród drobnoustrojów powszechnie występujących w surowcach przyprawowych najliczniejsze są bakterie i pleśnie [McKee 1995]. Bakterie mogą niekorzystnie wpływać na jakość przypraw, a w związku z tym również dań przyrządzonych $\mathrm{z}$ wykorzystaniem zanieczyszczonych surowców przyprawowych. Z kolei pleśnie wytwarzają szkodliwe metabolity wtóne mykotoksyny [Gajewska i in. 2019]. Jak podają w swojej pracy Czerwińska i Piotrowski [2005], do najbardziej zanieczyszczonych mikroorganizmami suszy przyprawowych należą: czarny pieprz, papryka, goździki, cynamon, kminek i majeranek.
\end{abstract}

\footnotetext{
${ }^{1}$ SKN Mikrobiologów „Mikrobios”, Wydział Agrobioinżynierii, Katedra Mikrobiologii Środowiskowej, Uniwersytet Przyrodniczy w Lublinie

2 Opiekun SKN Mikrobiologów,Mikrobios”, Wydział Agrobioinżynierii, Katedra Mikrobiologii Środowiskowej, Uniwersytet Przyrodniczy w Lublinie, justyna.bohacz@up.lublin.pl
} 
Borowy i Kubiak [2010] wymieniają Aspergillus, Penicillium, Fusarium i Rhizopus jako najczęściej obserwowane na przyprawach rodzaje grzybów strzępkowych. Przetaczek-Rożnowska i in. [2016] oraz Waldon i Hać-Szymańczuk [2015] podają, że przyczyną obecności mikroorganizmów, które powodują obniżenie jakości przypraw, jest także higiena osób pracujących podczas produkcji, a także nieodpowiednie warunki suszenia, przechowywania, niehigieniczny zbiór oraz transport.

Produkty roślinne poddawane rozmaitym procesom mają na celu zwiększenie ich trwałości do dalszego wykorzystywania przez konsumentów. Powinny charakteryzować się niską zawartością wody $\left(\mathrm{a}_{\mathrm{w}}<0,6\right)$, co wpływa negatywnie na rozwój mikroorganizmów. Występowanie określonych gatunków drobnoustrojów na surowcach roślinnych o określonych uzdolnieniach do ich psucia uwarunkowane jest także składem chemicznym tych surowców [Libudzisz i in. 2009].

Celem niniejszej pracy było nie tylko określenie składu ilościowego i jakościowego mikroorganizmów występujących na wybranych przyprawach dostępnych na rynku krajowym, ale również zbadanie uzdolnień hydrolitycznych wyizolowanych z przypraw pleśni.

\section{Material i metodyka}

\section{Material}

Materiał do badań stanowiło 9 wybranych przypraw dostępnych na rynku krajowym. Były to: liść laurowy (Laurus nobilis L.), pieprz czarny mielony (Piper nigrum L.), pieprz czarny ziarnisty (Piper nigrum L.), papryka słodka (Capsicum annumm L.), papryka ostra (Capsicum annuum L.), ziele angielskie (Pimenta dioica L), majeranek (Origanum majorana L.), kminek cały (Carum carvi L.), tymianek (Thymus vulgaris L.).

\section{Oznaczanie liczebności i składu rodzajowego mikroorganizmów}

Analiza mikrobiologiczna obejmowała oznaczanie ogólnej liczebności bakterii mezofilnych na podstawie normy PN-ISO 4833 i bakterii termofilnych, ogólnej liczby drożdży i grzybów pleśniowych dla surowców o niskiej aktywności wodnej [PN-ISO 21527-2]. Dodatkowo grzyby mezofilne i termofilne izolowano na podłożu Matrina [1950]. Liczebność drobnoustrojów została oznaczona metodą „płytek lanych” [Lee 2015]. Założone hodowle grzybów mezofilnych prowadzono w termostacie w temperaturze $25^{\circ} \mathrm{C}$ a bakterii w $28^{\circ} \mathrm{C}$. Grzyby i bakterie termofilne inkubowano $\mathrm{w} 45^{\circ} \mathrm{C}$. Wyrosłe kolonie grzybów pleśniowych przeszczepiano na skosy z pożywką PDA (agar glukozowo-ziemniaczany). Identyfikację rodzajową wyizolowanych pleśni prowadzono na podstawie cech makro- i mikroskopowych na płytkach Petriego i skosach agarowych. Cechy mikroskopowe w mikrokulturach obejmowały określanie kształtu zarodników, budowy konidioforów i strzępek zarodnionośnych, a także ciał owocujących. Ostatecznej klasy- 
fikacji dokonano na podstawie kluczy systematycznych Domscha i in. [2007] oraz Watanabe'a i in. [2010]. Dwa rodzaje, które reprezentowały najliczniejszą grupę wyizolowanych grzybów pleśniowych poddano identyfikacji gatunkowej opartej na amplifikacji fragmentów ITS za pomocą reakcji PCR i sekwencjonowania nukleotydów. Identyfikacja została przeprowadzona w IBB PAN w Warszawie.

\section{Oznaczanie aktywności enzymów hydrolitycznych wyizolowanych pleśni}

Do oznaczania aktywności enzymów hydrolitycznych (amylolitycznych i proteolitycznych) wytypowano mezofilne pleśnie wyizolowane z liścia laurowego, które reprezentowały najliczniejszą grupę z rodzajów Penicillium i Aspergillus. Były to grzyby: 1. Byssochlamys spectabilis (Udagawa \& Shoji Suzuki) Houbraken \& Samson - stadium teleomorfy Peacilomyces variotii Bainier [synonim Penicillium variotii (Bainier) Sacc.]; 2. Penicillium citrinum Thom i 3. Aspergillus niger Tiegh (obecnie Aspergillus brasiliensis Varga, Frisvad \& Samson stadium teleomorfy).

Hodowle stacjonarne tych grzybów założono na $100 \mathrm{~cm}^{3}$ pożywki płynnej w kolbach Erlenmayera o pojemności $300 \mathrm{~cm}^{3}$. Podłoże do oznaczania aktywności enzymów amylolitycznych zawierało $0,3 \%$ ekstrakt drożdżowy i skrobię (2\%) jako jedyne źródło węgla (C) i energii. Aktywność enzymów proteolitycznych pleśni prowadzono na podłożu o składzie $\left(\mathrm{g} / \mathrm{dm}^{3}\right): \mathrm{NaCl}$ (firma Chempur) 3,$0 ; \mathrm{K}_{2} \mathrm{HPO}_{4}$ (Chempur) 1,$5 ; \mathrm{KH}_{2} \mathrm{PO}_{4}$ (Chempur) 0,5 ; żelatyna (Sigma)-6; glukoza (POCH) 0,05; pepton (Biocorp) 0,1 ; bulion (Biocorp) $5 \mathrm{~cm}^{3} ; \mathrm{H}_{2} \mathrm{O}$ destylowana $1 \mathrm{dm}^{3}$. Podłoża zaszczepiono, stosując jako inokulum przerośnięty odpowiednią 7-dniową grzybnią krążek agarowy o średnicy $1 \mathrm{~cm}$.

Warianty doświadczalne przygotowano $\mathrm{w}$ trzech powtórzeniach i inkubowano przez okres $28 \mathrm{dni}$ w temperaturze $28^{\circ} \mathrm{C}$. Hodowle kontrolne stanowiły pożywki niezaszczepione grzybami. Okresowo, tj. po 7, 14, 21 i 28 dniach, przeprowadzano oznaczenia aktywności zewnątrzkomórkowych enzymów amylolitycznych i proteolitycznych w hodowlach doświadczalnych wytypowanych grzybów według metodyki podanej w opracowaniu Gniewosz i Lipińskiej [2013].

W celu wykazania istotnych różnic w aktywności enzymów amylolitycznych i proteolitycznych pomiędzy trzema badanymi szczepami grzybów zastosowano jednoczynnikową analizę wariancji (ANOVA), po której zastosowano procedurę porównań wielokrotnych (test HSD Tukeya) na poziomie istotności $\alpha=0,05$.

\section{Wyniki i dyskusja}

\section{Liczebność mikroorganizmów}

Na podstawie uzyskanych wyników badań własnych stwierdzono różną liczebność bakterii i grzybów mezofilnych oraz termofilnych w badanych przyprawach (tab. 1). Bakterie mezofilne znajdowały się w każdej z badanych przy- 
praw. Największą ich liczebność stwierdzono w majeranku oraz na papryce słodkiej. Bakterie termofilne występowały w każdej przyprawie z wyjątkiem pieprzu ziarnistego. Najwyższa liczebność tych mikroorganizmów była w majeranku. Badania Wójcik-Stopczyńskiej i in. [2010] wykazały, że liczebność mezofilnych bakterii tlenowych na świeżych przyprawach mieściła się w przedziale $3,6 \cdot 10^{4}-3,6 \cdot 10^{6} \mathrm{jtk} \cdot \mathrm{g}^{-1}$. Liczebność ta była na zbliżonym bądź wyższym poziomie niż uzyskane liczebności bakterii w niniejszej pracy. Świadczyć to może o tym, że proces utrwalania/suszenia świeżych roślin w celu otrzymywania przypraw skutkuje nie tylko przedłużeniem trwałości roślin przyprawowych, ale także sprzyja zmniejszaniu się ogólnej liczby bakterii.

Liczebność grzybów mezofilnych i termofilnych była znikoma na obydwu zastosowanych podłożach (tab. 1). Najliczniej grzyby te występowały na liściu laurowym. Na podłożu DRBC (agar z dichloranem, różem bengalskim i chloroformem) rozwinęły się jedynie grzyby $\mathrm{z}$ tymianku, kminku i majeranku oraz na liściu laurowym, gdzie liczebność ich była najwyższa $\left(118,18 \mathrm{jtk} \cdot \mathrm{g}^{-1}\right)$. Obecności grzybów termofilnych na tym podłożu nie stwierdzono. Na podłożu Martina zanotowano grzyby mezofilne obecne zwłaszcza na liściu laurowym.

Grzyby termofilne wyizolowano jedynie z kminku. Gajewska i Głowacka [2017] podają, że w badanych przez nie 14 rodzajach próbek przypraw (czosnek mielony, koperek, natka pietruszki, bazylia, oregano, estragon, tymianek, majeranek, gałka muszkatołowa, curry, kurkuma, pieprz czarny mielony, papryka słodka mielona, cynamon) ilość grzybów nie przekroczyła poziomu $10^{4} \mathrm{jtk} \cdot \mathrm{g}^{-1}$. Autorki najwięcej grzybów zaobserwowały w próbkach papryki słodkiej $\left(7,8 \cdot 10^{4} \mathrm{jtk} \cdot \mathrm{g}^{-1}\right)$.

Tabela 1. Liczebność (jtk $10^{2} \mathrm{~g}^{-1}$ ) bakterii oraz strzępkowych grzybów mezofilnych i termofilnych na przyprawach

\begin{tabular}{|l|c|c|c|c|c|}
\hline \multirow{2}{*}{\multicolumn{1}{|c|}{ Przyprawy }} & \multicolumn{2}{|c|}{ Liczebność grzybów strzępkowych } & \multicolumn{2}{c|}{} \\
\cline { 2 - 5 } & \multicolumn{2}{|c|}{ pożywka Martina } & $\begin{array}{c}\text { pożywka } \\
\text { DRBC }\end{array}$ & \multicolumn{2}{c|}{ Liczebność bakterii } \\
\cline { 2 - 5 } & mezofile & termofile & mezofile & mezofile & termofile \\
\hline Papryka ostra & 0,00 & 0,00 & 0,00 & 22,73 & 0,46 \\
Tymianek & 0,00 & 0,00 & 4,55 & 140,91 & 111,36 \\
Pieprz czarny mielony & 0,00 & 0,00 & 0,00 & 90,91 & 62,27 \\
Kminek cały & 0,00 & 4,55 & 4,55 & 4,55 & 0,46 \\
Liść laurowy & 77,27 & 0,00 & 118,18 & 22,73 & 11,82 \\
Majeranek & 0,00 & 0,00 & 4,55 & 659,09 & 246,67 \\
Papryka słodka & 0,00 & 0,00 & 0,00 & 377,27 & 23,64 \\
Ziele angielskie & 4,54 & 0,00 & 0,00 & 13,64 & 2,50 \\
Pieprz czarny ziarnisty & 4,54 & 0,00 & 0,00 & 63,64 & 0,00 \\
\hline
\end{tabular}




\section{Rodzaje grzybów pleśniowych występujące na przyprawach}

Identyfikacja gatunkowa za pomocą cech mikro- i makromorfologicznych wyizolowanych z badanych przypraw grzybów wskazała na obecność grzybów z rodzaju Penicillium sp., Aspergillus sp., Mucor sp. i Trichoderma sp. Według badań Abdel-Hafez i in. [1984] wykonanych na pięciu przyprawach, wśród których znalazły się kumin, nasiona kolendry, anyż, koper włoski oraz kminek, głównym zanieczyszczeniem grzybowym była obecność w przyprawach Aspergillus fumigatus. Natomiast Aziz and Youssef [1991] liczną obecność pleśni Aspergillus flavus oraz Aspergillus parasiticus zaobserwowali na różnych przyprawach powszechnie stosowanych w okolicach Egiptu, do których należały m.in. biały pieprz, nasiona kolendry oraz kurkuma.

\section{Aktywność enzymów proteolitycznych w hodowlach pleśni}

Wójcik-Stopczyńska i in. [2010] podają, że ze względu na niską trwałość świeżych ziół są one zwykle przetwarzane na susze. Zanieczyszczenie drobnoustrojami ziół świeżych i utrwalonych może być przyczyną ich zepsucia oraz zepsucia potraw z nimi wytworzonych, przyczyniać się do zmian sensorycznych i stanowić zagrożenie zdrowotne. Obniżenie ich wartości odżywczej oraz potraw przygotowywanych $\mathrm{z}$ ich udziałem związane jest m.in. z mikrobiologicznym rozkładem związków organicznych.

Grzyby z rodzaju Aspergillus i Penicillium znane są z uzdolnień do rozkładu związków wielkocząsteczkowych $\mathrm{z}$ uwagi na posiadanie szerokiego spektrum enzymów hydrolitycznych [Metin i in. 2010, Aydoğdu i in. 2012, Ortiz i in. 2016].

Przeprowadzone badania wykazały, że największą aktywnością enzymów proteolitycznych charakteryzuje się szczep grzyba Byssochlamys spectabilis. Po 7 dniach hodowli aktywność enzymów wytwarzanych przez tego grzyba wyniosła 93,33 U, po czym nieznacznie wzrosła. W 28. dniu hodowli aktywność tego enzymu osiągnęła najwyższą wartość 138,27 U (rys. 1).

Aktywność enzymów proteolitycznych wydzielanych przez Penicillium citrinum $\mathrm{w} 7$. dniu hodowli była najniższa $\mathrm{w}$ porównaniu $\mathrm{z}$ aktywnością tych enzymów wydzielanych przez Aspergillus niger oraz Byssochlamys spectabilis ich aktywność była większa odpowiednio o $54,27 \%$ oraz $83,47 \%$. W 28 . dniu hodowli aktywność enzymów proteolitycznych w hodowlach Byssochlamys spectabilis była wyższa od aktywności w pozostałych hodowlach grzybów (rys. 1).

Jak podają Liu i in. [1998], na aktywność proteolityczną enzymów wydzielanych przez dziki szczep Aspergillus niger wpływała metoda hodowli. Wykazali oni, że unieruchomienie komórek znacząco zmniejszało aktywność tych enzymów z $128 \mathrm{U} / \mathrm{g}$ do $28 \mathrm{U} / \mathrm{g}$ komórek, zwłaszcza w hodowlach wytrząsanych. An [2012] i Agrawal i in. [2005] stwierdzili, że aktywność proteaz wydzielanych przez grzyby zależy od pH i temperatury. An [2012] wykazał, że aktywność enzymów proteolitycznych wydzielanych przez Penicillum citrinum jest wyso$\mathrm{ka} \mathrm{w}$ temperaturze $40^{\circ} \mathrm{C}$ i pH 7,0 i wynosi $91,78 \pm 2,01 \mathrm{UI} \cdot \mathrm{cm}^{3}$. Agrawal i in. 
[2005] wykazali, że gdy temperatura hodowli Penicillum sp. wynosi $30^{\circ} \mathrm{C} \pm 2^{\circ} \mathrm{C}$, to aktywność enzymów proteolitycznych po tygodniu kształtuje się na poziomie $2897 \pm 265 \mathrm{U} / \mathrm{g}^{-1}$ IDS (początkowego suchego substratu, którym było białko sojowe). Jest to wartość znacznie wyższa niż uzyskana w badaniach własnych (rys. 1).

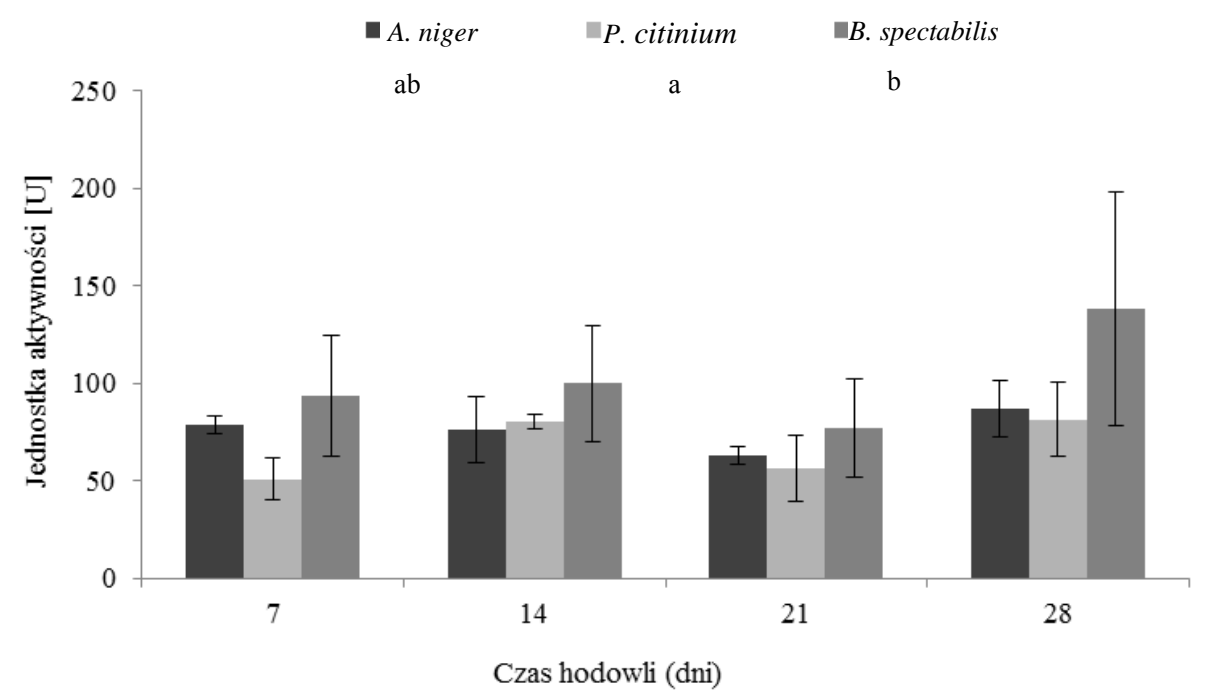

Rys. 1. Zmiany aktywności enzymów proteolitycznych w hodowlach szczepów grzybów strzępkowych wyizolowanych z wybranych przypraw

\section{Aktywność enzymów amylolitycznych w hodowlach pleśni}

Przeprowadzane badania wykazały, że istotnie największą aktywnością enzymów amylolitycznych, podobnie jak proteolitycznych, charakteryzował się szczep Byssochlamys spectabilis w porównaniu z P. citrinum (rys. 1, 2). W hodowlach tego grzyba aktywność enzymów amylolitycznych zwiększała się sukcesywnie w miarę czasu hodowli. Był to największy, bo aż 422\% wzrost aktywności enzymów amylolitycznych w porównaniu z początkową aktywnością tych enzymów wydzielanych przez Penicllium citrinum oraz Aspergillus niger.

W przypadku Aspergillus niger największy wzrost aktywności enzymów amylolitycznych zanotowano w dniu 28. hodowli i była to aktywność na poziomie 4,62 JAA. Aktywność enzymów amylolitycznych wydzielanych przez $P e-$ niclilium citrinum stopniowo rosła do 21 . dnia hodowli grzyba, po czym nieznacznie spadła. Aktywność uległa zwiększeniu w 21. dniu hodowli o 2,82 JAA w porównaniu z aktywnością z 7. dnia hodowli. 


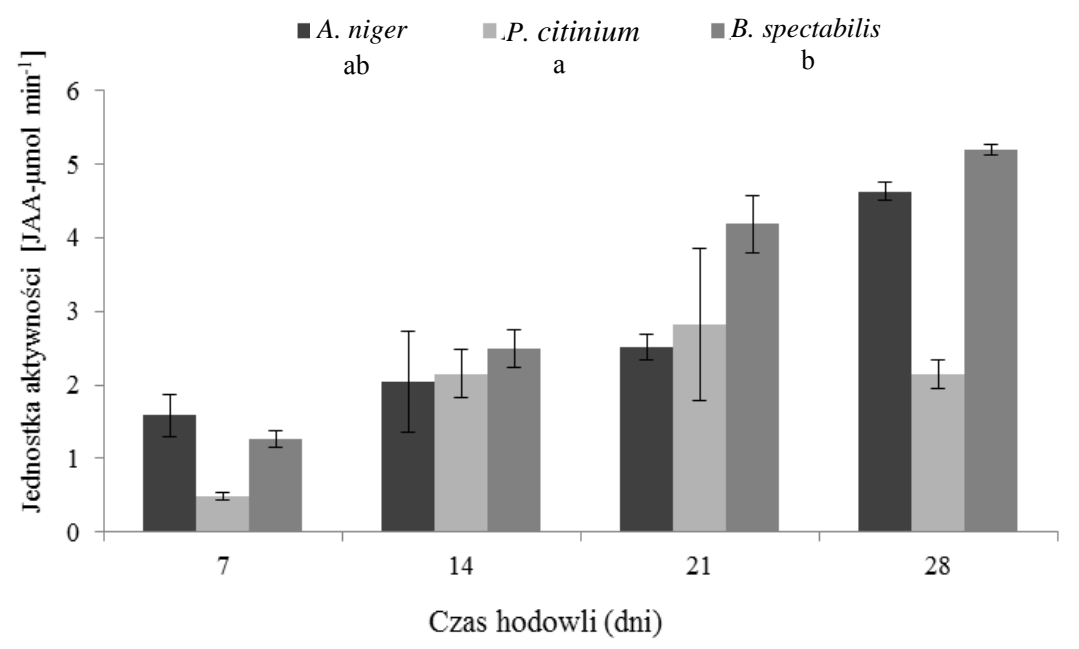

Rys. 2. Zmiany aktywności enzymów amylolitycznych w hodowlach szczepów grzybów strzępkowych wyizolowanych $\mathrm{z}$ wybranych przypraw

Według Doyle i in. [1998] szczep Byssochlamys spectabilis wytwarza enzymy: $\alpha$-amylazę i amyloglukozydazę. Autorzy ci wykazali, że enzymy te należą do endoamylaz i największą aktywność osiągają w pH 4-4,5 w temp. $40^{\circ} \mathrm{C}$. Natomiast Hernández i in. [2005] wykazali, że Aspergillus niger wytwarza amylazę o najwyższej aktywności w temperaturze $50^{\circ} \mathrm{C}$ i $\mathrm{pH} 4,95$. Zatem można stwierdzić, że odpowiednie warunki hodowli grzybów mają wpływ na intensywność wydzielania enzymów zewnątrzkomórkowych i ich aktywność.

\section{Podsumowanie}

Przyprawy dopuszczone do sprzedaży na rynku krajowym z uwagi na swoje walory smakowe wykorzystywane w przygotowywaniu potraw muszą charakteryzować się brakiem drobnoustrojów obniżających jakość potraw oraz brakiem drobnoustrojów patogennych i wytwarzających szkodliwe metabolity.

W niniejszej pracy wykazano niską liczebność bakterii oraz grzybów mezofilnych i termofilnych na większości badanych przypraw. Bakterie mezofilne i termofilne najliczniej występowały na majeranku. Wśród badanych przypraw liść laurowy był najliczniej zasiedlony przez grzyby mezo- i termofilne. Do grzybów izolowanych z przypraw należały: Penicillium sp., Aspergillus sp., Mucor sp. i Trichoderma sp. Wykazano, że największą aktywnością enzymów amylolitycznych i proteolitycznych charakteryzował się szczep Byssochlamys spectabilis. 
Pozyskane z przypraw grzyby z rodzaju Bysssochlamys, Penicillium i Aspergillus mogą być źródłem enzymów proteolitycznych i amylolitycznych do wykorzystania przemysłowego. Wymaga to dalszych badań nad oczyszczaniem tych enzymów, optymalizacją warunków hodowli oraz sprawdzenia, czy grzyby te nie wytwarzają toksycznych metabolitów, tj. mykotoksyn.

\section{Bibliografia}

Agrawal D., Patidar P., Banerjee T., Patil S., 2005. Alkaline protease production by a soil isolate of Beauveria felina under SSF condition: Parameter optimization and application to soy protein hydrolysis. Proc. Biochem. 40(3-4), 1131-1136.

An N.T., 2012. Study on the culture conditions for the protease production by Aspergillus unguis and Penicillium citrinum. Doctoral dissertation, International University HCMC, Vietnam.

Aydoğdu H., Balkan B., Balkan S., Ertan, F., 2012. Amylolytic activities of fungi species on the screening medium adjusted different pH. ÜFBED - Fen Bilimleri Enstitüsü Dergisi Cilt-Sayı: 5-1 Y11: 1-12.

Aziz N.H., Youssef Y.A., 1991. Occurrence of aflatoxins and aflatoxin-producing moulds in fresh and processed meat in Egypt. Food Addit. Contam. 8(3), 321-331.

Borowy T., Kubiak M.S., 2010. Mikrobiologiczne zanieczyszczenia przypraw naturalnych. Gosp. Mięsna 48(1), 14, 16.

Ceylan E., Fung D.Y.C., 2007. Antimicrobial activity of spices. J Rapid. Meth. Aut. Mic. 12(1), 1-55.

Czerwińska E., Piotrowski W., 2005. Czystość mikrobiologiczna przypraw i ich aktywność bakteriostatyczna. Zesz. Nauk. Wydz. Budownictwa i Inżynierii Środowiska 22, 253-263.

Domsch K.H., Gams W., Anderson T.H., 2007. Compendium of soil Fungi. IHW-Verlag Eching, München.

Doyle E., Noone A., Kelly C., Quigley T., Fogarty W., 1998. Mechanisms of action of the maltogenic $\alpha$-amylase of Byssochlamys fulva. Enzyme Microb. Tech. 22(7), 612-616

Gajewska M., Głowacka A., 2017. Ocena zanieczyszczenia grzybami pleśniowymi suszonych zió i przypraw dostępnych w sklepach ekologicznych i hipermarketach. ŻNTJ 24, 3(112), 51-59.

Gajewska M., Wyka K., Bartodziejska B., Szosland-Fałtyn A., 2019. Grzyby pleśniowe, groźne zanieczyszczenie ziół przyprawowych i przypraw. Mat. XLIV Konferencji Komitetu Nauk o Żywności i Żywieniu PAN „Nauka, Technologia i Innowacje w Żywności i Żywieniu”, Łódź, 1021.

Gniewosz M., Lipińska E. (red.), 2013. Zastosowanie wybranych drobnoustrojów w biotechnologii żywności. PWN, Warszawa, 113-119, 260-264.

Hernández M.S., Rodríguez M.R., Guerra N P., Rosés R.P., 2006. Amylase production by Aspergillus niger in submerged cultivation on two wastes from food industries. J. Food Eng. 73(1), 93-100.

Lee P.S., 2015. Quantitation of microorganisms. [W:] Practical Handbook of Microbiology, 3 ed, Goldman E., Green L.H. (eds.). CRC, Taylor \& Francis Group, 19.

Libudzisz Z., Kowal K., Żakowska Z., 2007. Mikrobiologia techniczna. Mikroorganizmy i środowiska ich występowania, t. 1. PWN, Warszawa.

Liu F., Li W., Ridgway D., Gu T., Moo-Young M., 1998. Inhibition of extracellular protease secretion by Aspergillus niger using cell immobilization. Biotechnol. Letters 20(6), 539-542.

Makała H., 2010b. Przyprawy i ich ekstrakty w przetwórstwie mięsa. Przem. Spoż. 64(3), 26-28.

Makała H., 2010a. Przyprawy do żywności - charakterystyka i właściwości. Przem. Spoż. 64, 32-35.

Martin J.P., 1950. Use of acid rose bengal and streptomycin in the plate method of estimating soil fungi. Soil Sci. 69, 215-233.

McKee L.H., 1995. Microbial contamination of spices and herbs. LWT-Food Sci. Technol. 28(1) $1-11$. 
Metin K., Koç Ö., Ateşlier Z.B.B., Bıyık H.H., 2010. Purification and characterization of $\alpha$-amylase produced by Penicillium citrinum HBF62. Afr. J. Biotechnol. 9(45), 7692-7701.

Ortiz G.E., Noseda D.G., Mora M.C.P., Recupero M.N., Blasco M., Albertó E., 2016. A Comparative Study of New Aspergillus Strains for Proteolytic Enzymes Production by Solid State Fermentation. Enzyme Res., https://doi.org/10.1155/2016/3016149.

Przetaczek-Rożnowska I., Kuźniak M., 2016. Źródła zanieczyszczeń mikrobiologicznych ziół leczniczych i przypraw oraz metody ich dekontaminacji. Post. Fitoter. 1, 59-62.

PN-EN ISO 4833-2004. Mikrobiologia żywności i pasz. Horyzontalna metoda oznaczania liczby drobnoustrojów. Metoda płytkowa w temperaturze $30^{\circ} \mathrm{C}$.

PN-ISO 21527-2. Mikrobiologia żywności i pasz, Horyzontalna metoda oznaczania liczby drożdży i pleśni, cz. 2: Metoda liczenia kolonii w produktach o aktywności wody niższej lub równej 0,95.

Waldon E., Hac-Szymanczuk E., 2015. Ocena zanieczyszczenia mikrobiologicznego wybranych przypraw. Post. Nauki Technol. Przem. Rol.-Spoż. 1(70), 61-73.

Watanabe T., 2010. Pictorial atlas of soil and seed fungi. Morphologies of cultured fungi and key to species. CRP Press, Boca Raton.

Wójcik-Stopczynska B., Jakowienko P., Jadczak D., 2010. Ocena mikrobiologiczna zanieczyszczenia świeżej bazylii i mięty. ŻNTJ 17(4), 122-131. 
Magda Marciniewicz ${ }^{1}$, Agnieszka Starek $\oplus^{2}$, Agnieszka Sagan $\oplus^{3}$

\title{
Wpływ parametrów pasteryzacji na właściwości chemiczne i mikrostrukturę soku pomidorowego
}

\author{
Influence of pasteurization parameters on chemical properties and microstructure of tomato juice
}

\begin{abstract}
Wstęp
Współczesny stan wiedzy żywieniowej wskazuje, że warzywa i owoce oraz ich przetwory powinny mieć stałe miejsce w diecie i być spożywane nawet kilka razy w ciągu dnia [Maasland i in. 2015, Hayes 2016]. Spośród tych produktów na szczególną uwagę zasługują pomidory i ich przetwory. Są one bardzo dobrym źródłem karotenoidów oraz związków flawonoidowych, a także witaminy C. Wśród karotenoidów głównym pigmentem odpowiedzialnym za charakterystyczny, głęboko czerwony kolor dojrzałych owoców pomidora jest likopen. Wykazano, że spożywanie pomidorów i ich produktów zawierających ten związek wiąże się ze zmniejszonym ryzykiem chorób cywilizacyjnych, takich jak nowotwory i choroby sercowo-naczyniowe [Vinha i in. 2014, Ricci i in. 2017].

Soki owocowe i warzywne są wyrobami łatwo psującymi się, a niewłaściwe warunki podczas transportu i przechowywania mogą znacznie obniżyć ich jakość. $\mathrm{Z}$ tego względu w przemyśle spożywczym wyroby te poddaje się procesowi pasteryzacji, który ma ochronić produkt przed rozwojem patogennych drobnoustrojów. Jednak zastosowana obróbka cieplna może wpływać negatywnie na zawartość związków bioaktywnych w sokach owocowych i warzywnych [Bizri i Wahem 1994, Odriozola-Serrano i in. 2009, Starek i in. 2019]. Jak wykazały badania Hallmann i in. [2011], zastosowanie wysokiej temperatury do pasteryzacji wpłynęło na obniżenie zawartości $\beta$-karotenu i witaminy $\mathrm{C} w$ soku marchwiowym. Poddany pasteryzacji produkt zawierał również istotnie mniej kwasów fenolowych w porównaniu $\mathrm{z}$ sokiem świeżym.

Mimo iż pasteryzacja jest jedną z podstawowych metod stosowanych do utrwalania produktów spożywczych, istnieje niewiele publikacji na temat jej wpływu na jakość przetworów owocowo-warzywnych. Stąd też celem niniejsze-

\footnotetext{
${ }^{1}$ Studenckie Koło Naukowe Food Design, Katedra Biologicznych Podstaw Technologii Żywności i Pasz, Wydział Inżynierii Produkcji, Uniwersytet Przyrodniczy w Lublinie, m.marciniewicz96@gmail.com

${ }^{2}$ Katedra Biologicznych Podstaw Technologii Żywności i Pasz, Wydział Inżynierii Produkcji, Uniwersytet Przyrodniczy w Lublinie, agnieszka.starek@up.lublin.pl

${ }^{3}$ Katedra Biologicznych Podstaw Technologii Żywności i Pasz, Wydział Inżynierii Produkcji, Uniwersytet Przyrodniczy w Lublinie, agnieszka.sagan@up.lublin.pl
} 
go opracowania było określenie wpływu parametrów pasteryzacji na właściwości chemiczne i mikrostrukturę soku pomidorowego.

\section{Material i metody}

Świeże pomidory (Lycopersicon esculentum cv. Apis F1) zakupiono w gospodarstwie ogrodniczym (województwo lubelskie) prowadzącym biologiczną ochronę roślin. Badania prowadzono na surowcu zdrowym, bez uszkodzeń mechanicznych. Warzywa umyto, a następnie pokrojono na mniejsze części. Sok otrzymano przy użyciu wyciskarki wolnoobrotowej Philips Avance Collection HR1933/20.

Próbę kontrolną stanowił sok $\mathrm{z}$ owoców pomidora niepoddany obróbce cieplnej. Następnie próbki soków utrwalano za pomocą tradycyjnej pasteryzacji w słoikach o pojemności $150 \mathrm{ml}$, przy użyciu łaźni czterostanowiskowej z cyfrowym sterowaniem firmy AJL Electronic $w$ temperaturze:

a) $70^{\circ} \mathrm{C}$, w ciągu 2,5 i $10 \mathrm{~min}(\mathrm{~T} 70=2 \mathrm{~min} ; \mathrm{T} 70=5 \mathrm{~min}$; $\mathrm{T} 70=10 \mathrm{~min})$,

b) $90^{\circ} \mathrm{C}$ przez 2 , 5 i $10 \mathrm{~min}(\mathrm{~T} 90=2 \mathrm{~min}$; $\mathrm{T} 90=5 \mathrm{~min}$; $\mathrm{T} 90=10 \mathrm{~min})$.

Karotenoidy ogółem i likopen oznaczano metodą spektrofotometryczną, przy użyciu spektrofotometru Thermo Scientific UV-Vis Helios Omega 3 [Fish i in. 2002]. Metoda polegała na wyekstrahowaniu obu związków z badanej próbki mieszaniną: acetonu z $0,2 \%$ BHT, etanolu i heksanu (1:1:2) i oznaczeniu ich zawartości przez pomiar absorbancji fazy heksanowej przy długości fali $\lambda=470 \mathrm{~nm}$ (dla karotenoidów) i $\lambda=503 \mathrm{~nm}$ (dla likopenu) [González-Casado i in. 2018].

Zawartość witaminy C (kwasu L-askorbinowego) oznaczano metodą miareczkową zgodnie z Hallmann [2012]. Próbkę ekstrahowano 2\% kwasem szczawiowym, przefiltrowano i następnie miareczkowano 2,6-dichlorofenolindofenolem (barwnik Tillmansa) do uzyskania trwałego różowego zabarwienia.

Dodatkowo wykonano analizę mikroskopową świeżego soku pomidorowego (próbka kontrolna) oraz produktów poddanych utrwalaniu przy wykorzystaniu mikroskopu cyfrowego Keyence VHX 950F.

Analizę statystyczną wyników przeprowadzono, stosując jednoczynnikową analizę wariancji ANOVA $z$ testem Tukeya na poziomie istotności $p<0,05$ przy użyciu programu komputerowego Statistica 8.0. Doświadczenia przeprowadzono dwukrotnie, a wszystkie analizy wykonano w trzech powtórzeniach.

\section{Wyniki i dyskusja}

Wyniki pomiaru wpływu zastosowanych parametrów pasteryzacji na wartości badanych cech przedstawiono na rysunkach 1-3.

Pomidory i ich przetwory są istotnym źródłem karotenoidów w diecie człowieka. W pomidorach związki te są reprezentowane przez likopen i $\beta$-karoten. Barwniki te występują w zróżnicowanych ilościach zarówno w skórce, jak i w miąższu 
owoców [Jabłońska-Ryś i in. 2009]. Za charakterystyczny głęboko czerwony kolor dojrzałych owoców pomidora i produktów z pomidorów jest odpowiedzialny głównie likopen.

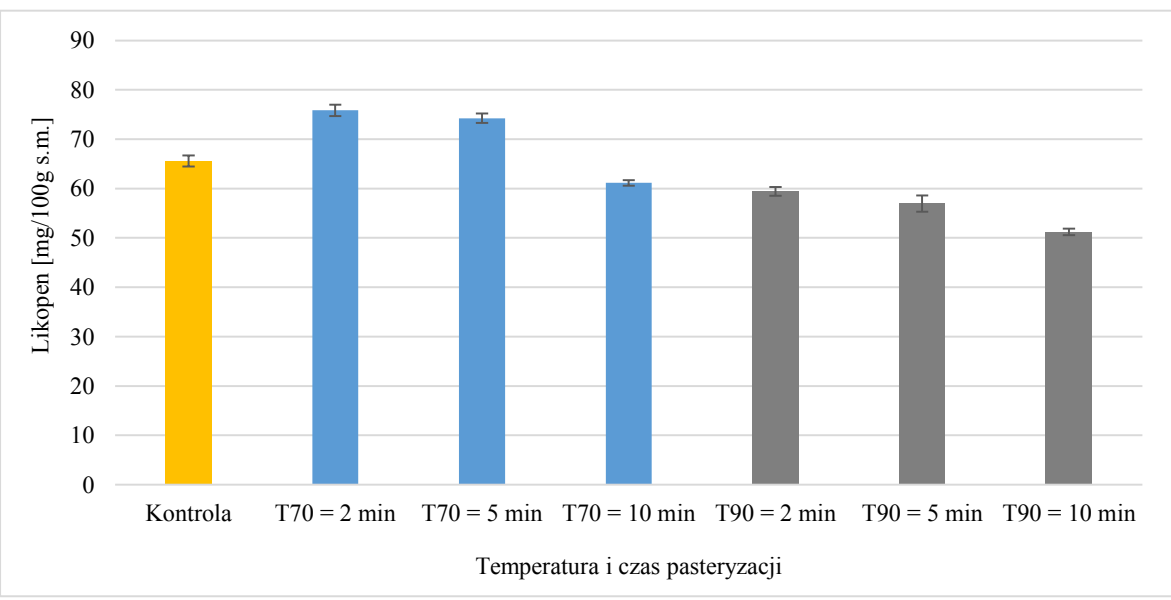

Rys. 1. Wpływ parametrów pasteryzacji na zawartość likopenu w soku pomidorowym

Wśród badanych soków najwyższą zawartością likopenu wyróżniał się sok poddany pasteryzacji w temperaturze $70^{\circ} \mathrm{C}$ przez $2 \mathrm{~min}-75,84 \mathrm{mg} / 100 \mathrm{~g} \mathrm{s.m}$. (rys. 1). Produkt ten charakteryzował się jednocześnie najwyższą zawartością karotenoidów $-83,25 \mathrm{mg} / 100 \mathrm{~g}$ s.m. (rys. 2). Ten niewielki wzrost zawartości barwników (w porównaniu z kontrolą) prawdopodobnie miał związek z uszkodzeniem błon komórkowych i uwolnieniem karotenoidów z kompleksów białkowych, co przełożyło się na możliwość ekstrakcji większej ich ilości niż z nieprzetwarzanych termicznie produktów roślinnych [Gryszczyńska i in. 2011]. Natomiast proces utrwalania przeprowadzony $\mathrm{w} 90^{\circ} \mathrm{C}$ przez $10 \mathrm{~min}$ skutkował degradacją likopenu i karotenoidów ogółem - ich zawartość wynosiła odpowiednio: 51,24 i $56,61 \mathrm{mg} / 100 \mathrm{~g} \mathrm{s.m}$. Analiza statystyczna (w większości przypadków) wykazała istotne różnice, jeśli chodzi o zawartość barwników w soku świeżo tłoczonym (kontrola) i produktach poddanych pasteryzacji.

Zaprezentowane wyniki są zbliżone do zamieszczonych przez OdriozolaSerrano i in. [2007], którzy stwierdzili, iż obróbka cieplna soku pomidorowego w zbyt wysokiej temperaturze oraz długi czas przechowywania wyrobu przyczyniają się do spadku zawartości karotenoidów. Przybylska i Felisiak [2012] również zanotowały obniżenie stężenia likopenu $\mathrm{w}$ przecierze pomidorowym pasteryzowanym przez 20,35 i 50 min i przechowywanym przez 1 miesiąc. Według Hsu [2008] oraz Kim i in. [2001] najbardziej korzystna pasteryzacja produktów zawierających likopen to proces prowadzony w $121^{\circ} \mathrm{C}$ przez 40 sek, albo $\mathrm{w} 92^{\circ} \mathrm{C}$ przez $5 \mathrm{~min}$, w kilku powtórzeniach oddzielonych interwałami o niższej temperaturze $\left(60^{\circ} \mathrm{C}\right)$. 


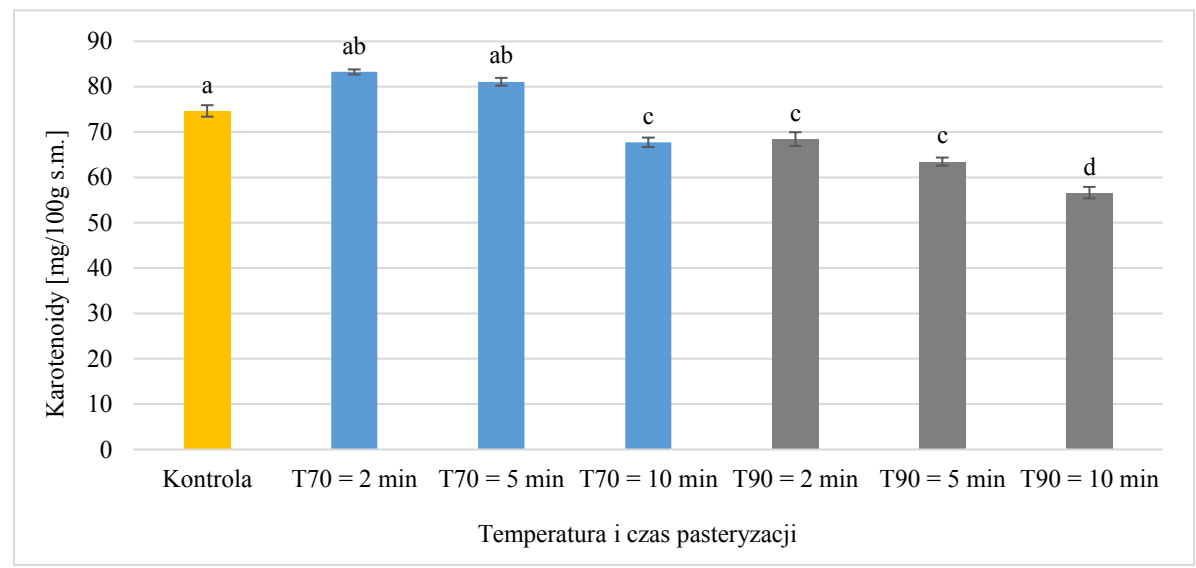

Rys. 2. Wpływ parametrów pasteryzacji na ogólną zawartość karotenoidów w soku pomidorowym

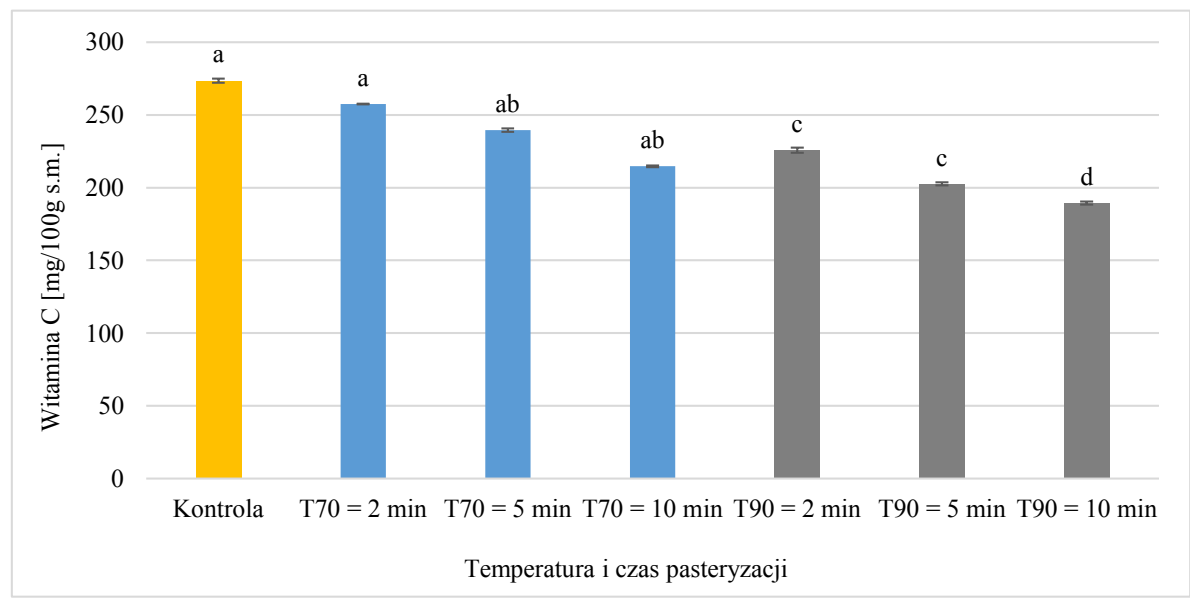

Rys. 3. Wpływ parametrów pasteryzacji na zawartość kwasu askorbinowego w soku pomidorowym

Witamina $\mathrm{C}$ jest najbardziej znanym antyoksydantem. Dzięki swoim właściwościom pełni ochronną rolę $\mathrm{w}$ chorobach serca i naczyń krwionośnych [Janda $\mathrm{i}$ in. 2015]. Jak podaje Hallmann [2012], zawartość witaminy $\mathrm{C}$ w pomidorach waha się od ok. 200 do $480 \mathrm{mg} / 100 \mathrm{~g}$ s.m. i jest zależna od roku zbiorów i metody uprawy. W badanym świeżym soku pomidorowym jej zawartości wynosiła $273,45 \mathrm{mg} / 100 \mathrm{~g}$ s.m. (rys. 3). Witamina C jest związkiem termolabilnym i procesy technologiczne z zastosowaniem wysokiej temperatury wpływają na przyspieszony rozkład tego biologicznie aktywnego składnika żywności [Hallmann i in. 2011].

Cieplne utrwalanie soku pomidorowego $\mathrm{w}$ temperaturze $70^{\circ} \mathrm{C}$ przez $10 \mathrm{~min}$ spowodowało obniżenie zawartości kwasu askorbinowego o $27 \% \mathrm{w}$ stosunku do próby kontrolnej. Natomiast pasteryzacja przeprowadzona w wyższej temperaturze $\left(90^{\circ} \mathrm{C}\right)$ przyczyniła się do degradacji tej witaminy o $31 \%$. 
Jak zauważyli Cendrowski i in. [2011], zawartość kwasu askorbinowego w dżemie z borówki wysokiej bezpośrednio po wyprodukowaniu wynosiła $8,9 \mathrm{mg} / 100 \mathrm{~g}$, co już w tym momencie stanowiło ok. 30-procentowe zmniejszenie zawartości w stosunku do surowca świeżego. Jednak największe ubytki kwasu askorbinowego wystąpiły w procesie pasteryzacji i wynosiły aż 58\% w stosunku do owocu surowego.

Rysunki 4 i 5 dotyczą mikrostruktury soku pomidorowego widocznego przy powiększeniu $100 \times$ w cyfrowej mikroskopii.

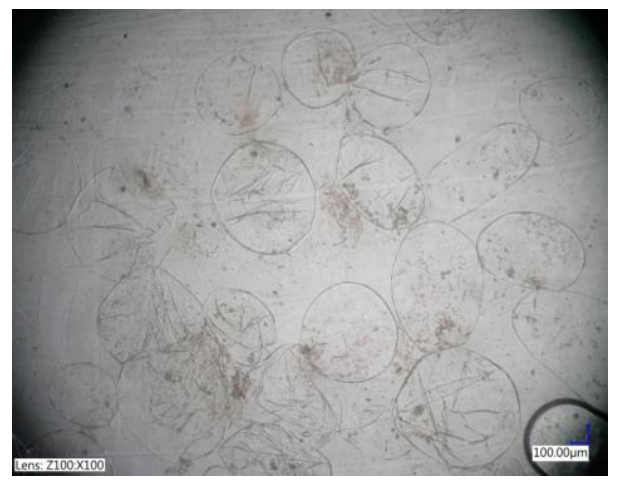

Rys. 4. Mikrostruktura świeżo tłoczonego soku pomidorowego

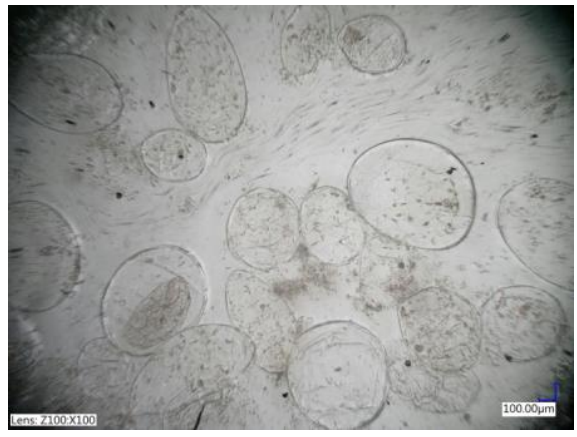

$\mathrm{T} 70=2 \mathrm{~min}$

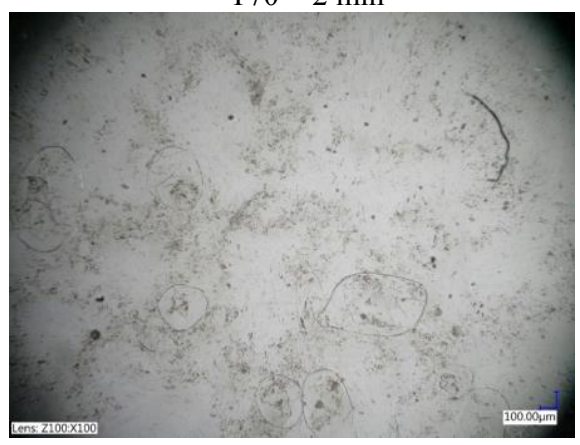

$\mathrm{T} 90=2 \mathrm{~min}$

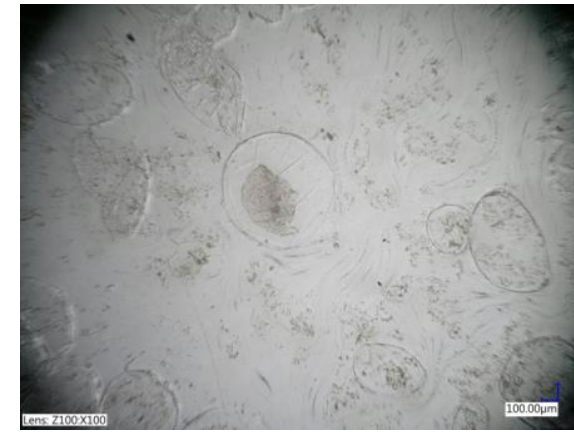

$\mathrm{T} 70=10 \mathrm{~min}$

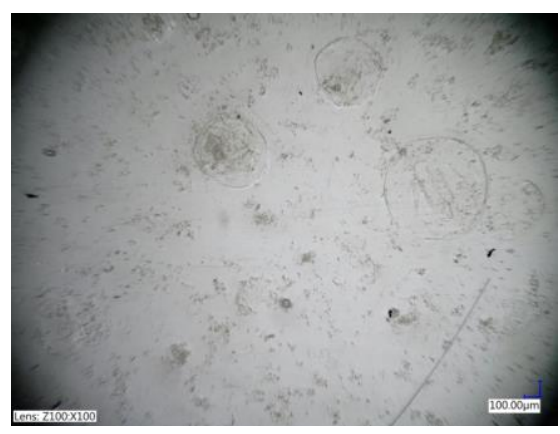

$\mathrm{T} 90=10 \mathrm{~min}$

Rys. 5. Mikrostruktura pasteryzowanego soku pomidorowego 
Sok pomidorowy, który nie był poddany utrwalaniu, zawierał niezniszczone komórki z nienaruszonymi organellami, zawierającymi karotenoidy, w tym tzw. kryształy likopenu.

Materiał poddany pasteryzacji $\mathrm{w}$ temperaturze $70^{\circ} \mathrm{C}$ i $90^{\circ} \mathrm{C}$ przez 2 min posiadał uszkodzone komórki $\mathrm{z}$ wewnętrznymi komponentami w zniszczonych komórkach, a także na zewnątrz, zawieszone w homogenacie soku. W produkcie poddanym pasteryzacji przez 10 minut nie zaobserwowano nienaruszonych komórek (zabarwione karotenoidy wypłynęły z chromoplastów oraz z komórek do bezpostaciowej części soku).

\section{Wnioski}

Przeprowadzone badania wykazały, że najkorzystniejszą obróbką soku pomidorowego była pasteryzacja przeprowadzona w temperaturze $70^{\circ} \mathrm{C}$ przez 2 do 5 min, gdzie badana zawartość karotenoidów ogółem i likopenu nieznacznie wzrosła. Podwyższenie temperatury procesu i wydłużenie czasu obróbki do 10 min spowodowały częściową degradację tych barwników. Cieplne utrwalanie soku pomidorowego $\mathrm{w}$ niższej temperaturze spowodowało degradację witaminy $\mathrm{C}$ o ok. $21 \%$ w porównaniu z próbą kontrolną. Natomiast pasteryzacja przeprowadzona w temperaturze $90^{\circ} \mathrm{C}$ skutkowała obniżeniem zawartości tej witaminy o $31 \%$. Na obrazach mikroskopowych wraz ze wzrostem czasu i temperatury utrwalania coraz trudniej było dostrzec wyraźne zarysy materiału komórkowego w soku pomidorowym, co sugeruje, że komórki zostały całkowicie uszkodzone.

\section{Bibliografia}

Bizri J.N., Wahem I.A., 1994. Citric acid and antimicrobials affect microbiological stability and quality of tomato juice. J. Food Sci. 59(1), 130-135. https://doi.org/10.1111/j.1365-2621.1994.tb06916.x

Cendrowski A., Ścibisz I., Mitek M., 2011. Wpływ warunków przechowywania na zawartość hydroksymetylofurfuralu, furfuralu i kwasu askorbinowego w dżemach z owoców jagodowych. ŻNTJ 6(79), 155-166.

Fish W.W., Perkins-Veazie P., Collins J.K., 2002. A quantitative assai for lycopene that utilizes reduced volumes of organic solvents. J. Food Comp. Anal. 15, 309-317. https://doi.org/10.1006/jfca.2002.1069

González-Casado S., Martín-Belloso O., Elez-Martínez P., Soliva-Fortuny R., 2018. Enhancing the carotenoid content of tomato fruit with pulsed electric field treatments: Effects on respiratory activity and quality attributes. Postharvest Biol. Tec. 137, 113-118. https://doi.org/10.1016/j.postharvbio.2017.11.017

Gryszczyńska A., Gryszczyńska B., Opala B., 2011. Karotenoidy. Naturalne źródła, biosynteza, wpływ na organizm ludzki. Post. Fitoter. 2, 127-143.

Hallmann E., 2012. The influence of organic and conventional cultivation systems on the nutritional value and content of bioactive compounds in selected tomato types. J. Sci. Food Agric. $92,2840-2848$. 
Hallmann E., Sikora M., Rembiałkowska E., Marszałek K., Lipowski J., 2011. The influence of pasteurization process on nutritive value of carrot juices from organic and conventional production. J. Res. Applic. Agric. Eng. 56(3), 133.

Hayes A.E., 2016. Diet high in lycopene might reduce prostate cancer risk. Pharm. Today 22(7), 24.

Hsu K.C., 2008. Evaluation of processing qualities of tomato juice induced by thermal and pressure processing. LWT - Food Sci. Technol. 41(3), 450-459. https://doi.org/10.1016/j.lwt.2007.03.022

Jabłońska-Ryś E., Zalewska-Korona M., 2009. The colour analysis and the content of carotenoids in fruits of new breeding lines of tomatoes. Bromat. Chem. Toksykol. 3, 926-931.

Janda K., Kasprzak M., Wolska J., 2015. Vitamin C - structure, properties, occurrence and functions. Pom. J. Life Sci. 61(4), 419-425.

Kim S. J., Nara, E., Kobayashi H., Terao J., Nagao A., 2001. Formation of cleavage products by autoxidation of lycopene. Lipids 36(2), 191, https://doi.org/10.1007/s11745-001-0706-8.

Maasland D.H., van den Brandt P.A., Kremer B., Goldbohm R.A. and Schouten L.J., 2015. Consumption of vegetables and fruits and risk of subtypes of head-neck cancer in the Netherlands cohort study. Int. J. Cancer. 136(5), E396-E409. https://doi.org/10.1002/ijc.29219

Odriozola-Serrano I., Soliva-Fortuny R., Hernández-Jover T. and Martín-Belloso O., 2009. Carotenoid and phenolic profile of tomato juices processed by high intensity pulsed electric fields compared with conventional thermal treatments. Food Chem. 112(1), 258-266, https://doi.org/10.1016/j.foodchem.2008.05.087.

Przybylska S., Felisiak K., 2012. Effect of selected additives on colour changes and lycopene content in pasteurized tomato pulps after storage. Polish J. Com. Sci. (1), 113-124.

Ricci A., Antonini E., Ninfali P., 2017. Homemade tomato sauce in the mediterranean diet: a rich source of antioxidants. Ital. J. Food Sci. 30(1), 37-49. https://doi.org/10.14674/IJFS-980

Starek A., Pawłat J., Chudzik B., Kwiatkowski M., Terebun P., Sagan A., Andrejko D., 2019. Evaluation of selected microbial and physicochemical parameters of fresh tomato juice after cold atmospheric pressure plasma treatment during refrigerated storage. Sci. Rep. 9(1), 1-11. https://doi.org/10.1038/s41598-019-44946-1

Vinha A.F., Alves R.C., Barreira S.V., Castro A., Costa A.S., Oliveira M.B.P., 2014. Effect of peel and seed removal on the nutritional value and antioxidant activity of tomato (Lycopersicon esculentum L.) fruits. LWT - Food Sci. Technol. 55(1), 197-202. https://doi.org/10.1016/j.lwt.2013.07.016 
Zuzanna Mariańczuk $^{1,2}$, Sylwia Michalak ${ }^{1}$, Małgorzata Kowczyk-Sadowy ${ }^{1}$

\title{
Badanie tekstury wybranych serów podpuszczkowych
}

Texture examination of selected rennet cheeses

\begin{abstract}
Wstęp
Charakterystyka produktów mlecznych

Mleko oraz jego przetwory to jedne z najważniejszych części składowych diety człowieka. Mleko towarzyszy ludziom już w pierwszych chwilach życia, to właśnie ono jest pierwszym pokarmem wszystkich ssaków. Musi zatem całkowicie zaspokajać potrzeby organizmu i dostarczać składników niezbędnych do rozwoju i wzrostu, dlatego też jego skład jest niesamowicie bogaty [Gawęcki i Pikul 2018]. Zawartość wapnia w mleku jest na tyle wysoka, że niewiele ponad pół szklanki mleka, czyli około $100 \mathrm{~g}$, dostarcza naszemu organizmowi ponad $10 \%$ zalecanej dziennej dawki [Valli 2018].

Brodziak i in. [2017] podają, iż konsumenci coraz częściej poszukują produktów prozdrowotnych, a mleko ze względu na swoiste składniki spełnia ich oczekiwania. Jest ono przetwarzane na wiele sposobów, co sprawia, że na sklepowych półkach spotyka się coraz więcej różnorodnych przetworów mlecznych. Producenci w ten sposób wychodzą naprzeciw konsumentom, aby każdy mógł znaleźć satysfakcjonujący go wyrób. Sektor artykułów mlecznych jest bardzo rozbudowany. Najliczniejszą grupę w tym sektorze stanowią sery.

Sery tworzą bardzo liczną i zróżnicowaną grupę żywności zarówno pod względem cech organoleptycznych, jak i składu chemicznego [Knysz i in. 2018]. Zdefiniowanie artykułu, jakim jest ser, jest bardzo trudne i wynika z różnorodności produktów kryjących się pod tą nazwą. Derengiewicz [1997] określa ser jako produkt otrzymywany za pomocą odpowiednio przeprowadzonej obróbki skrzepu, mającej na celu oddzielenie serwatki oraz otrzymanie wystarczająco odwodnionej masy, która po wykonaniu formowania, sprasowania, nasolenia oraz po odpowiednim dojrzewaniu daje nam produkt o właściwym smaku, zapachu, plastyczności oraz dużej wartości odżywczej.

Można spotkać się z podziałem serów ze względu na: gatunek mleka, z jakiego są wytwarzane, technologię wytwarzania skrzepu (rys. 1), zawartość wody w beztluszczowej masie sera oraz zawartość tłuszczu [Gawęcki i Pikul 2018].
\end{abstract}

\footnotetext{
${ }^{1}$ Wydział Budownictwa i Nauk o Środowisku, Politechnika Białostocka, Białystok

${ }^{2}$ marianczukz@gmail.com
} 


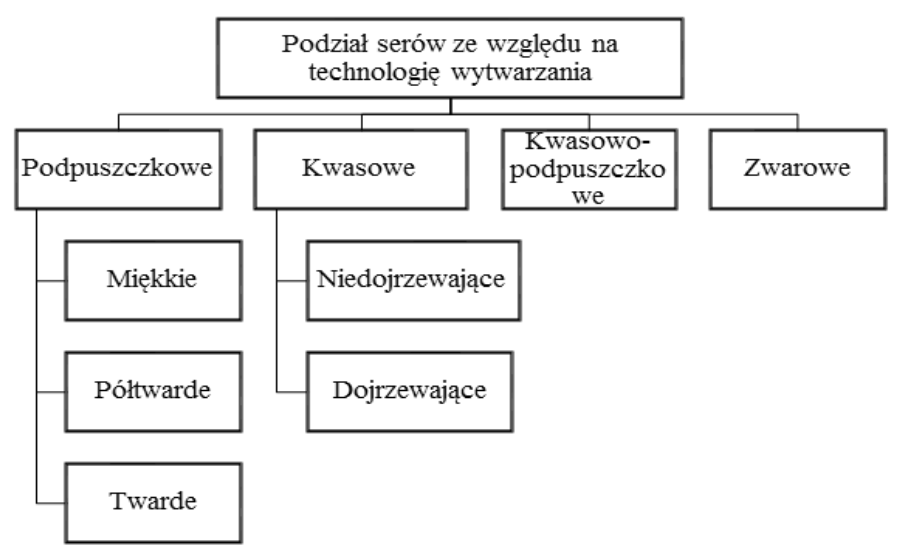

Rys. 1. Podział serów ze względu na technologię wytwarzania

W dalszym ciągu rozważań w niniejszej pracy uwagę skupiono na grupie serów podpuszczkowych.

\section{Analiza tekstury żywności}

Tekstura żywności określana jest jako jeden z podstawowych parametrów charakteryzujący produkty spożywcze i decydujący o ich jakości [Surówka 2002]. Norma PN-ISO 11036:1999 opisuje teksturę jako zbiór wszystkich cech mechanicznych, geometrycznych i powierzchniowych produktu, które człowiek może odebrać za pomocą receptorów mechanicznych, dotykowych, wzrokowych i słuchowych. W sensie fizycznym tekstura stanowi o właściwościach reologicznych produktu i cechuje ją zależność naprężenie-odkształcenie-czas [Marzec 2007].

$\mathrm{Z}$ teksturą żywności ludzie spotykają się każdego dnia, chociażby robiąc kanapkę, myślą, dlaczego masło nie chce się rozsmarować, pieczywo nie da się przekroić, mięso nie jest kruche, a ketchup przystaje do noża. Dlatego też tekstura określana jest jako cecha nie tylko sensoryczna, ale też psychologiczna, i jest powiązana $z$ budową chemiczną, strukturą oraz właściwościami reologicznymi produktów [Surówka 2002].

Mimo iż często klienci nie zdają sobie z tego sprawy, to właśnie tekstura jest głównym czynnikiem decydującym o zakupie danego produktu. Dlatego ma ona ogromne znaczenie zarówno dla konsumenta, jak i producenta. Tekstura kształtuje przyzwyczajenia żywieniowe, gdyż zazwyczaj konsument wybiera wyroby mniej twarde, delikatniejsze, kruche oraz soczyste. Jest to oczywiście uwarunkowane subiektywnymi upodobaniami konsumenta. Jak dowodzą badania, pożądaną cechą produktów jest występujący w nich kontrast teksturalny, przykład tego stanowią kruche ciastka z miękkim nadzieniem. Dla konsumenta tekstura zazwyczaj jest wartością oczywistą i zwraca na nią uwagę dopiero, gdy spotyka produkt o teksturze przez niego nieakceptowanej [Surówka 2002]. 
Teksturę można określić metodami sensorycznymi oraz instrumentalnymi. $\mathrm{W}$ instrumentalnych metodach badania tekstury wykorzystuje się specjalistyczną aparaturę pomiarową oraz urządzenia mechaniczne. W porównaniu $\mathrm{z}$ metodami sensorycznymi są tańsze, gdyż nie wymagają wyspecjalizowanego zespołu oceniającego oraz zapewniają większą powtarzalność wyników. Zastosowanie metod instrumentalnych daje pewność, iż wynik nie jest uwarunkowany osobistymi upodobaniami [Dolik i in. 2010].

Celem badań było określenie siły cięcia, pracy cięcia, jędrności oraz adhezyjności serów białych podpuszczkowych typu korycińskiego. Cechy te analizowano dla serów świeżych oraz po dwumiesięcznym mrożeniu.

\section{Metodyka badań}

Materiał badawczy stanowiły cztery sery podpuszczkowe białe typu korycińskiego. Były to sery naturalne oraz $\mathrm{z}$ dodatkami smakowymi w postaci czosnku i czarnuszki (tab. 1). Miejsca ich zakupu były zróżnicowane, sery różniły się także

Tabela 1. Oznaczenia badanych serów

\begin{tabular}{|c|l|l|}
\hline Oznaczenie & \multicolumn{1}{|c|}{ Nazwa sera } & \multicolumn{1}{|c|}{ Miejsce zakupu } \\
\hline 1 & ser biały podpuszczkowy bez dodatków & supermarket \\
2 & ser biały podpuszczkowy bez dodatków & gospodarstwo rolne \\
3 & ser biały z dodatkiem czosnku & supermarket \\
4 & ser biały z dodatkiem czarnuszki & supermarket \\
\hline
\end{tabular}

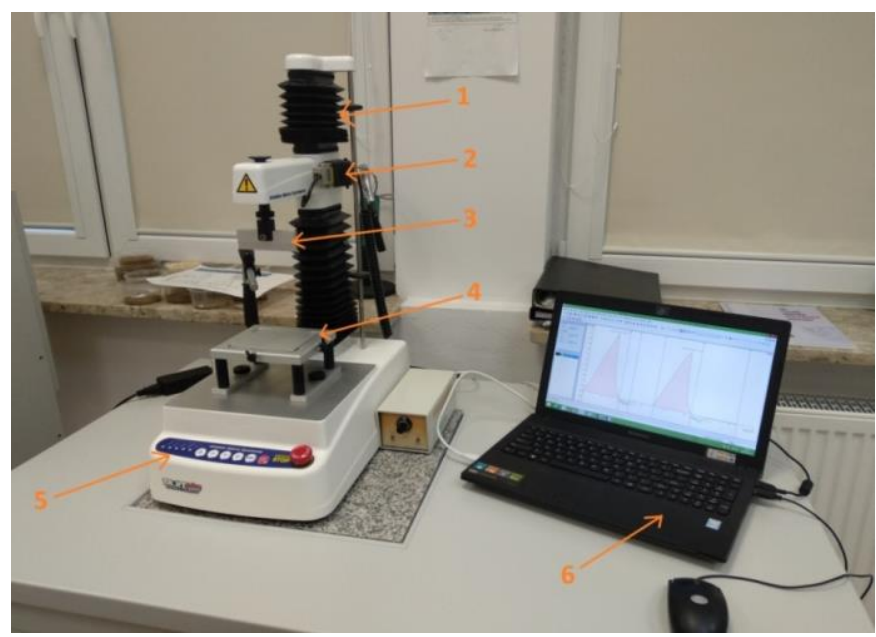

Rys. 2. Stanowisko do badania tekstury żywności. Oznaczenia: 1 - suwnica, 2 - ogniwo obciążnikowe, 3 - przyrząd pomiarowy, 4 - platforma pomiarowa, 5 - kontroler z wyłącznikiem, 6 - komputer $\mathrm{z}$ oprogramowaniem Exponent 
ceną. Najdroższy był ser biały podpuszczkowy z dodatkiem czarnuszki, który kosztował $40 \mathrm{zt} / \mathrm{kg}$, najtańsze były sery białe podpuszczkowe naturalne. Ser zakupiony w supermarkecie kosztowa $35 \mathrm{z} / \mathrm{kg}$, natomiast ser wyprodukowany $\mathrm{w}$ małym, tradycyjnym gospodarstwie rolnym $30 \mathrm{zt} / \mathrm{kg}$.

Analizę tekstury przeprowadzono z zastosowaniem Teksturometru TA.XT plus firmy Stable Micro Systems z zastosowaniem 50-kilogramowego ogniwa obciążnikowego (rys. 2).

Po dobraniu i montażu odpowiedniego przyrządu badaną próbkę sera umiejscowiono na platformie pomiarowej tak, aby narzędzie skierowane było prostopadle do badanej próbki. Próbki sera były przygotowane wg normy PN-ISO 11036:1999 jako sześciany o boku $1,25 \mathrm{~cm}$. W zależności od badanej właściwości tekstury dobrano odpowiedni przyrząd pomiarowy oraz zwalidowano metodę badawczą $\mathrm{z}$ zastosowaniem oprogramowania komputerowego Exponent. Analizowano sery świeże oraz po dwumiesięcznym mrożeniu.

\section{Badanie jednostkowej siły cięcia i pracy cięcia}

Zestaw do badania jednostkowej siły cięcia oraz pracy cięcia składał się z ostrza Warnera-Bratzlera, odwracalnego ostrza, wkładki z rowkiem oraz uchwytu ostrza. Maksymalną siłę oraz wykonaną pracę przyjęto jako wskaźnik twardości próbki. Siły deformujące próbkę to: siły ściskające, rozciągające oraz ścinające. Dlatego też wyniki potraktowano jako odporność próbek na odkształcenia w danych warunkach. Maksymalna siła wyznaczona została w momencie, gdy próbka wypełniła całkowicie trójkątną wnękę ostrza i przecięła powierzchnię próbki [www.stablemicrosystems.com].

\section{Badanie jędrności oraz adhezyjności}

Do przeprowadzenia badania jędrności oraz adhezyjności serów podpuszczkowych użyta została sonda w kształcie kuli (rys. 3). Zgodnie z metodami badawczymi podanymi przez oprogramowanie Exponent wybrana została sonda $\mathrm{P} / 0,25 \mathrm{~S}$ o rozmiarze mniejszym od wielkości próbki. Badanie polegało na dwukrotnym zagłębieniu sondy w badany ser do uzyskania odkształcenia wynoszą-

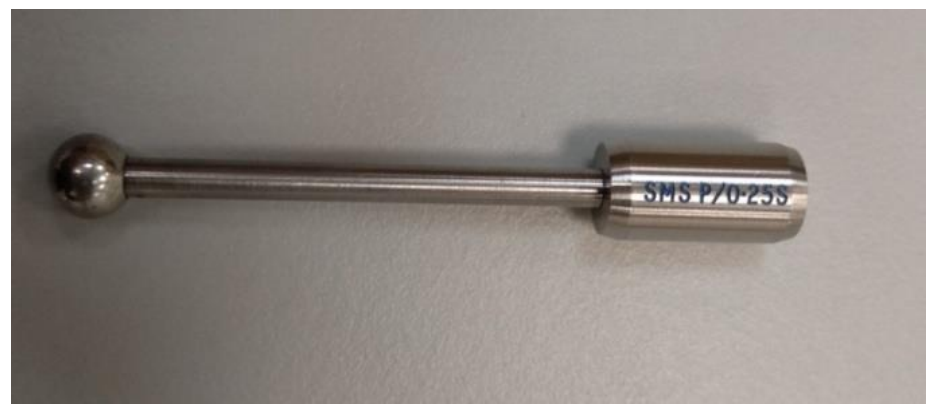

Rys. 3. Sonda użyta do badania jędrności i adhezyjności 
cego 20\% (test podwójnego ściskania). Wynikiem badania w oprogramowaniu Exponent była funkcja sily względem czasu. Obszar pod wykresem w zakresie dodatnich wartości siły stanowił o jędrności próbki, natomiast w zakresie siły ujemnej o jej adhezyjności.

\section{Wyniki}

\section{Jednostkowa sila cięcia i praca cięcia}

Praca cięcia i siła cięcia są podstawowymi parametrami pozwalającymi na jednoznaczne określenie twardości badanej próbki. Badanie przeprowadzone dla próbek świeżych i próbek po dwumiesięcznym mrożeniu wykazało różnice w ich twardości. Sery zostały oznaczone numerami od 1 do 4 (tab. 2). Przygotowano 10 próbek każdego z serów.

Tabela 2. Oznaczenia sera podczas badania jednostkowej siły cięcia i pracy cięcia

\begin{tabular}{|c|c|}
\hline Oznaczenie & Rodzaj sera \\
\hline 1 & ser biały podpuszczkowy naturalny świeży \\
\hline $1 \mathrm{~m}$ & ser biały podpuszczkowy naturalny po mrożeniu \\
\hline 2 & $\begin{array}{l}\text { ser biały podpuszczkowy naturalny wyprodukowany w małym, tradycyjnym } \\
\text { gospodarstwie świeży }\end{array}$ \\
\hline $2 \mathrm{~m}$ & $\begin{array}{l}\text { ser biały podpuszczkowy naturalny wyprodukowany w małym, tradycyjnym } \\
\text { gospodarstwie po mrożeniu }\end{array}$ \\
\hline 3 & ser biały podpuszczkowy z dodatkiem czosnku świeży \\
\hline $3 \mathrm{~m}$ & ser biały podpuszczkowy z dodatkiem czosnku po mrożeniu \\
\hline 4 & ser biały podpuszczkowy z dodatkiem czarnuszki świeży \\
\hline $4 \mathrm{~m}$ & ser biały podpuszczkowy z dodatkiem czarnuszki po mrożeniu \\
\hline
\end{tabular}

Z powyższego wykresu (rys. 4) można odczytać, iż największa praca cięcia została wykonana do przecięcia sera białego podpuszczkowego z dodatkiem czarnuszki i była równa $36,59 \mathrm{~N} / \mathrm{mm} \cdot \mathrm{s}$, najmniejsza natomiast wynosiła $28,86 \mathrm{~N} / \mathrm{mm} \cdot \mathrm{s}$ i uzyskano ją, przecinając ser biały podpuszczkowy naturalny zakupiony w supermarkecie. Wyniki pracy cięcia dla sera białego podpuszczkowego naturalnego zakupionego w małym, tradycyjnym gospodarstwie rolnym oraz dla sera białego podpuszczkowego $\mathrm{z}$ dodatkiem czosnku były porównywalne. Po okresie dwumiesięcznego mrożenia jednostkowa praca cięcia znacznie zmalała, dla sera białego podpuszczkowego zakupionego w supermarkecie odnotowano spadek wynoszący $60,2 \%$, a dla sera białego podpuszczkowego z dodatkiem czarnuszki $53,5 \%$. Swiadczy to o wyraźnym zmniejszeniu twardości serów. Wynika to z faktu, iż $\mathrm{w}$ trakcie mrożenia następuje zmiana struktury wody zawartej w serze, a tym 
samym powstają zmiany w jego strukturze (rozpad wiązań chemicznych), stąd obserwowalna mniejsza siła cięcia. Bernaś i in. [2007], badając twardość pieczarek, również odnotowali spadek ich twardości po procesie zamrażania, wynoszący od $80 \%$ do $88 \%$ w stosunku do badania twardości produktu świeżego.

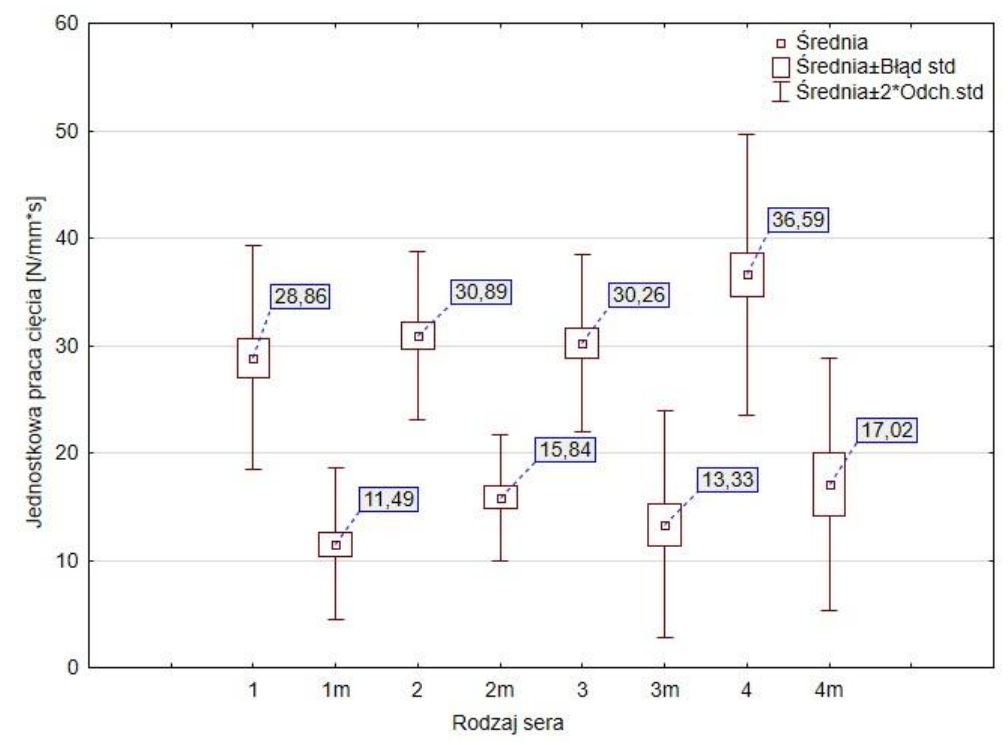

Rys. 4. Jednostkowa praca cięcia: 1, 2, 3, 4 - sery świeże; $1 \mathrm{~m}, 2 \mathrm{~m}, 3 \mathrm{~m}, 4 \mathrm{~m}$ - sery po mrożeniu

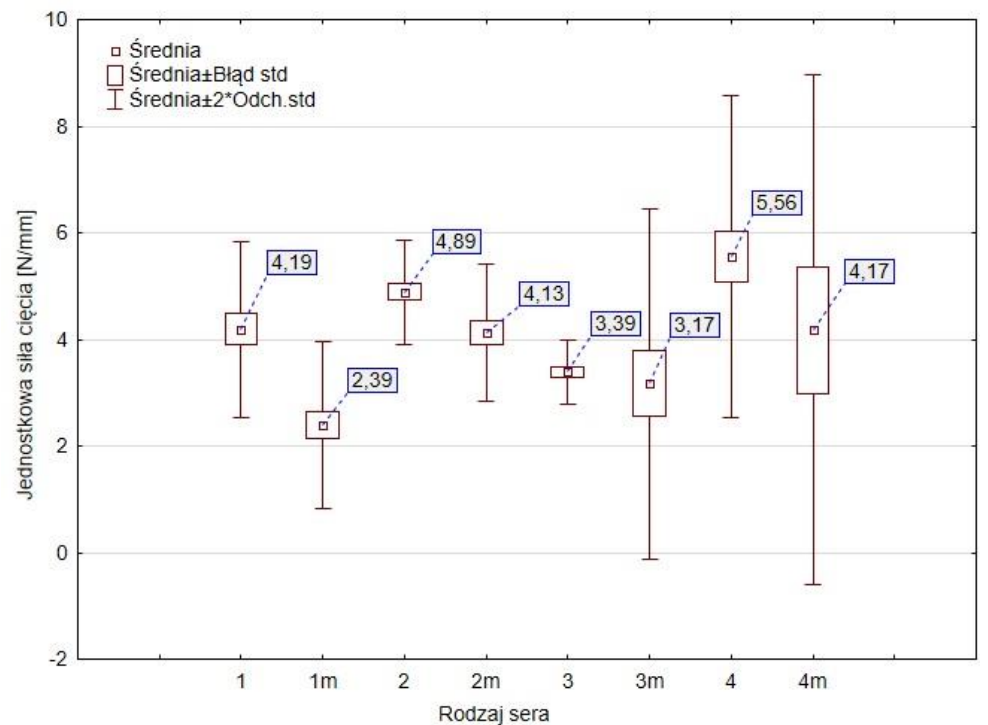

Rys. 5. Jednostkowa siła cięcia: 1, 2, 3, 4 - sery świeże; $1 \mathrm{~m}, 2 \mathrm{~m}, 3 \mathrm{~m}, 4 \mathrm{~m}$ - sery po mrożeniu 
Dla serów świeżych (rys. 5) największa siła cięcia niezbędna była do przecięcia sera nr 4, czyli sera białego podpuszczkowego z dodatkiem czarnuszki, i wynosiła ona 5,56 N/mm. Najmniejsza praca cięcia wynosiła 3,29 N/mm i włożona została do przecięcia sera $\mathrm{nr} 3$, tj. sera białego podpuszczkowego $\mathrm{z}$ dodatkiem czosnku. Po mrożeniu siła cięcia, podobnie jak praca cięcia, spadła i najmniejszą siłą cięcia cechował się ser biały podpuszczkowy naturalny zakupiony w supermarkecie, siła ta wynosiła zaledwie 2,39 N/mm. Kwaśniewska-Karolak [2017], badając teksturę papryki, zauważyła znaczny spadek siły cięcia po zaledwie tygodniowym mrożeniu, zarówno $\mathrm{w}$ przypadku temperatury mrożenia $-80^{\circ} \mathrm{C}$, jak i $-20^{\circ} \mathrm{C}$. Podobne obserwacje przeprowadził Półtorak [2007], badając ciasto półfrancuskie. Dowiódł, że wszystkie badane cechy tekstury dla ciasta mrożonego były mniejsze niż dla ciasta świeżego. Największe odchylenie standardowe zauważalne jest dla sera białego podpuszczkowego $\mathrm{z}$ dodatkiem czarnuszki, co spowodowane jest niejednorodnością próbki wynikającą ze znajdujących się w serze ziaren czarnuszki. W momencie gdy narzędzie pomiarowe natrafiało na znajdujące się w próbce ziarno czarnuszki potrzebna była większa siła do jego przecięcia. Biorąc pod uwagę zarówno jednostkową siłę, jak i pracę cięcia, można stwierdzić, iż serem o największej twardości okazał się ser biały podpuszczkowy z dodatkiem czarnuszki. Cechował się również największym odchyleniem standardowym uzyskanych wyników badań.

\section{Badanie jędrności i adhezyjności}

Jędrność i adhezyjność sera zostały określone za pomocą testu podwójnego ściskania. Oznaczenia serów wykorzystane w teście podwójnego ściskania przedstawiono w tabeli 3 .

Tabela 3. Oznaczenia serów w teście podwójnego ściskania

\begin{tabular}{|c|l|}
\hline Oznaczenie & \multicolumn{1}{c|}{ Rodzaj sera } \\
\hline 1 & $\begin{array}{l}\text { ser biały podpuszczkowy naturalny - ściśnięcie pierwsze } \\
\text { ser biały podpuszczkowy naturalny - ściśnięcie drugie }\end{array}$ \\
$1 \mathrm{a}$ & $\begin{array}{l}\text { ser biały podpuszczkowy naturalny wyprodukowany w małym, tradycyj- } \\
\text { nym gospodarstwie rolnym - ściśnięcie pierwsze }\end{array}$ \\
2 & $\begin{array}{l}\text { ser biały podpuszczkowy naturalny wyprodukowany w małym, tradycyj- } \\
\text { nym gospodarstwie rolnym - ściśnięcie drugie }\end{array}$ \\
$2 \mathrm{a}$ & $\begin{array}{l}\text { ser biały podpuszczkowy z dodatkiem czosnku - ściśnięcie pierwsze } \\
\text { ser biały podpuszczkowy z dodatkiem czosnku - ściśnięcie drugie }\end{array}$ \\
$3 \mathrm{a}$ & $\begin{array}{l}\text { ser biały podpuszczkowy z dodatkiem czarnuszki - ściśnięcie pierwsze } \\
\text { ser biały podpuszczkowy z dodatkiem czarnuszki - ściśnięcie drugie }\end{array}$ \\
$4 \mathrm{a}$ &
\end{tabular}




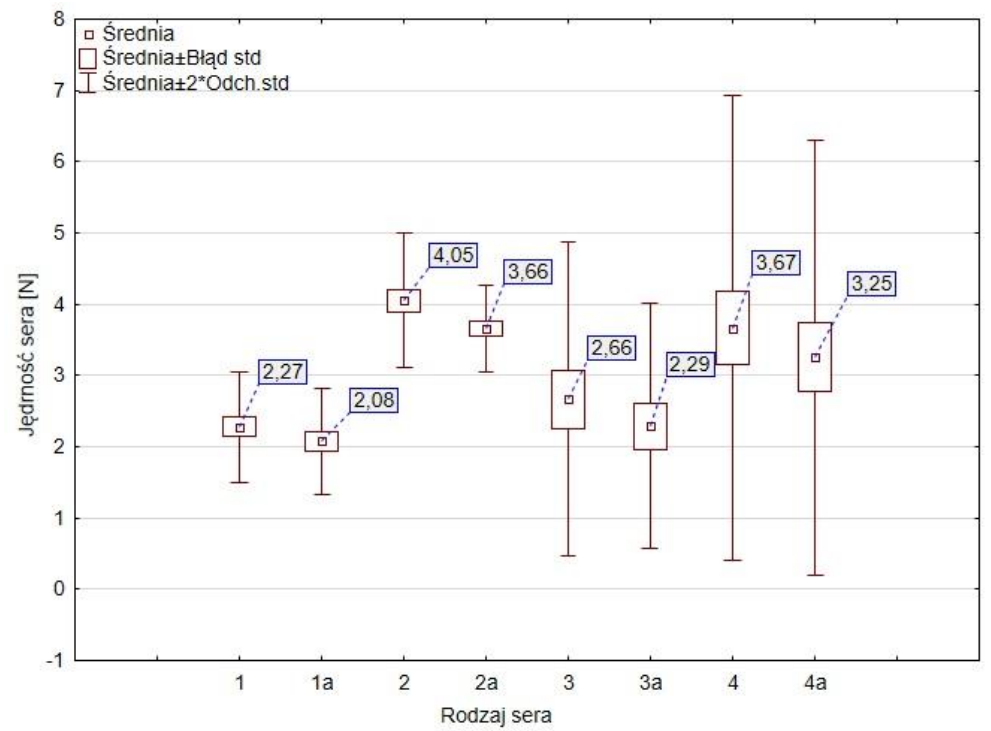

Rys. 6. Jędrność sera świeżego: 1, 2, 3, 4 - ściśnięcie pierwsze; 1a, 2a, 3a, 4a - ściśnięcie drugie

Zakres sił dodatnich decydujący o jędrności sera wykazał, że największą jędrnością cechował się ser biały podpuszczkowy naturalny pochodzący z małego, tradycyjnego gospodarstwa rolnego. Najmniejszą jędrnością odznaczał się ser podpuszczkowy biały naturalny zakupiony w supermarkecie. Zauważalny jest spadek sił podczas drugiego ściskania, co spowodowane jest odkształceniem w zakresie odkształceń plastycznych struktury sera po pierwszym ściśnięciu. Najmniejsze odchylenie standardowe widoczne jest w próbkach sera białego podpuszczkowego zakupionego w supermarkecie, natomiast większe odchylenia standardowe dotyczą próbek sera białego podpuszczkowego $\mathrm{z}$ dodatkiem czosnku oraz sera białego podpuszczkowego $\mathrm{z}$ dodatkiem czarnuszki (rys. 6). Tak duże odchylenia spowodowane były niejednorodnością próbek wynikającą z obecności dodatków smakowych.

Po dwumiesięcznym okresie mrożenia największą jędrnością cechował się ser biały podpuszczkowy naturalny wyprodukowany w małym, tradycyjnym gospodarstwie rolnym. Najmniejszą jędrność miał ser biały podpuszczkowy naturalny zakupiony w supermarkecie i wynosiła ona $2,35 \mathrm{~N} ; 2,09 \mathrm{~N}$ oraz ser biały podpuszczkowy z dodatkiem czosnku 2,34 N; 2,1 N. Po dwumiesięcznym mrożeniu zauważono wyraźny spadek jędrności w stosunku do jędrności serów świeżych (rys. 7). Dla sera białego podpuszczkowego naturalnego zakupionego w supermarkecie zarejestrowano spadek wynoszący $11,06 \%$, dla sera białego podpuszczkowego naturalnego zakupionego w małym, tradycyjnym gospodarstwie rolnym $11,81 \%$, a dla sera białego podpuszczkowego z dodatkiem czarnuszki 16,92\%. Andziak i in. [2009], prowadząc badania jędrności jabłek, także odnotowali jej spadek po kilkumiesięcznym przechowywaniu owoców. Może to być konsekwencją odwodnienia (ususzka chłodnicza) produktu wskutek procesu 
mrożenia. Dostrzegalny jest także wyraźnie wyższy poziom jędrności sera naturalnego bez dodatków w porównaniu z innymi serami, zatem możliwe, iż mniejsza jędrność sera uwarunkowana jest dodatkami smakowymi.

Na wykresie (rys. 8) przedstawiono adhezyjność sera świeżego.

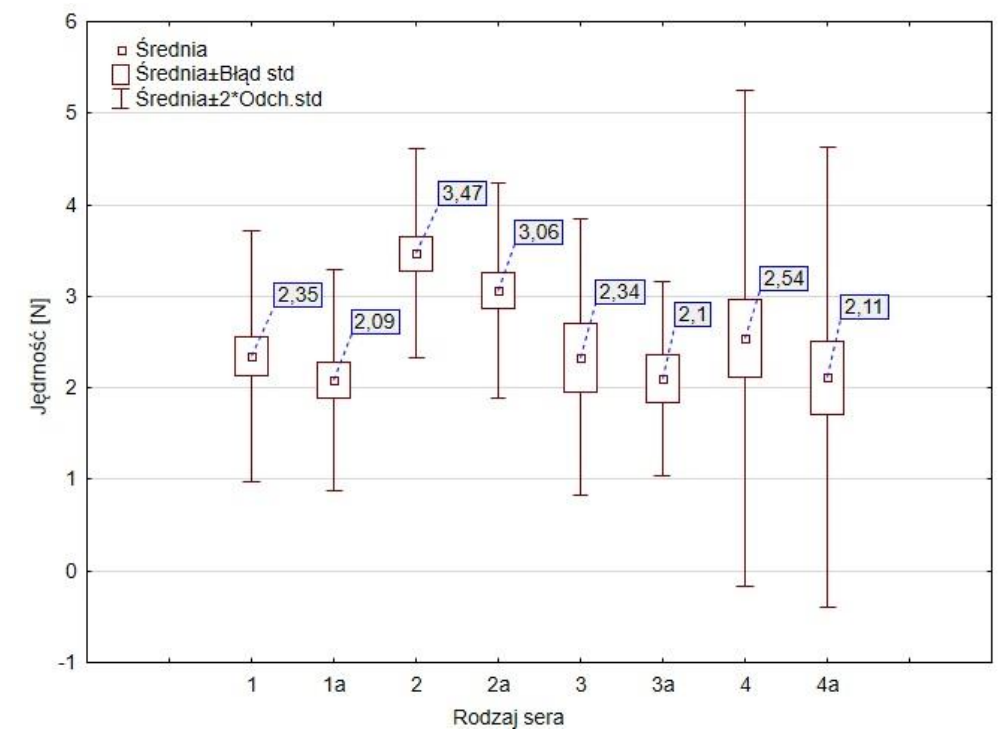

Rys. 7. Jędrność sera po mrożeniu: 1, 2, 3, 4 - ściśnięcie pierwsze; 1a, 2a, 3a, 4a - ściśnięcie drugie

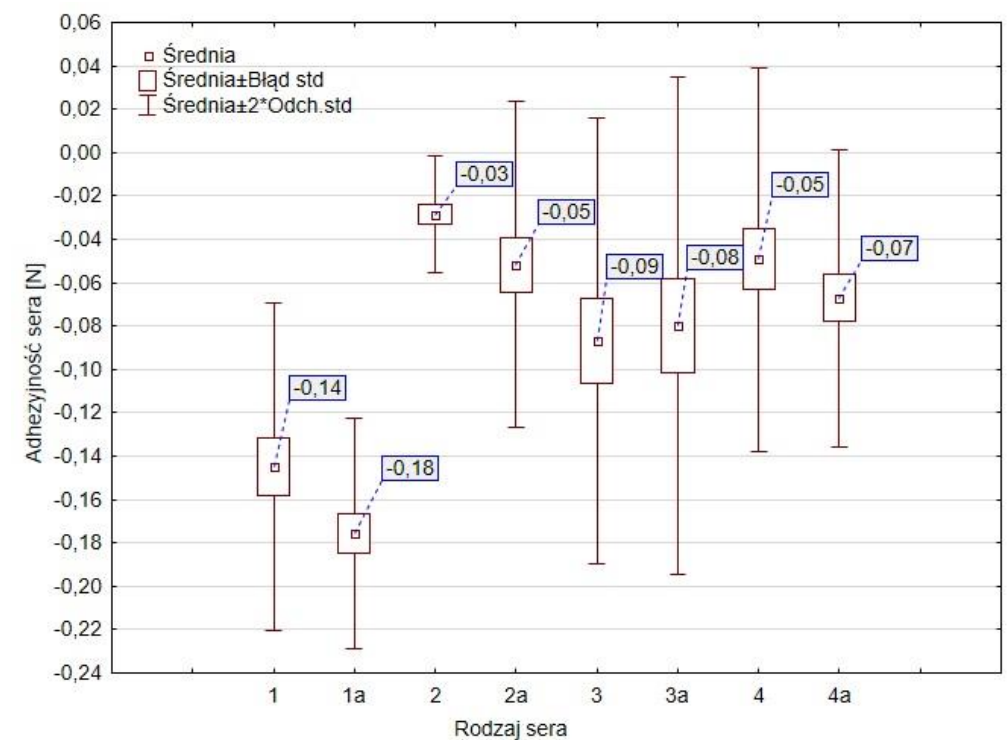

Rys. 8. Adhezyjność sera świeżego: 1, 2, 3, 4-ściśnięcie pierwsze; 1a, 2a, 3a, 4a - ściśnięcie drugie 
Adhezyjność jest właściwością decydującą o przyleganiu sera do innych powierzchni, w tym przypadku do powierzchni sondy. W celu ułatwienia zobrazowania badania podano wartość ujemną siły ze względu na przeciwny wektor działania w stosunku do badania jędrności. Podczas analizy sera świeżego największą adhezyjnością wyróżniał się ser biały podpuszczkowy naturalny zakupiony w supermarkecie, a najmniejszą ser biały podpuszczkowy naturalny wyprodukowany w małym, tradycyjnym gospodarstwie. Wszystkie $\mathrm{z}$ badanych serów odznaczały się większą adhezyjnością podczas drugiego ściśnięcia, co może być spowodowane naruszeniem struktur próbki podczas zagłębienia pierwszego oraz odkształceniami próbki w zakresie odkształceń plastycznych.

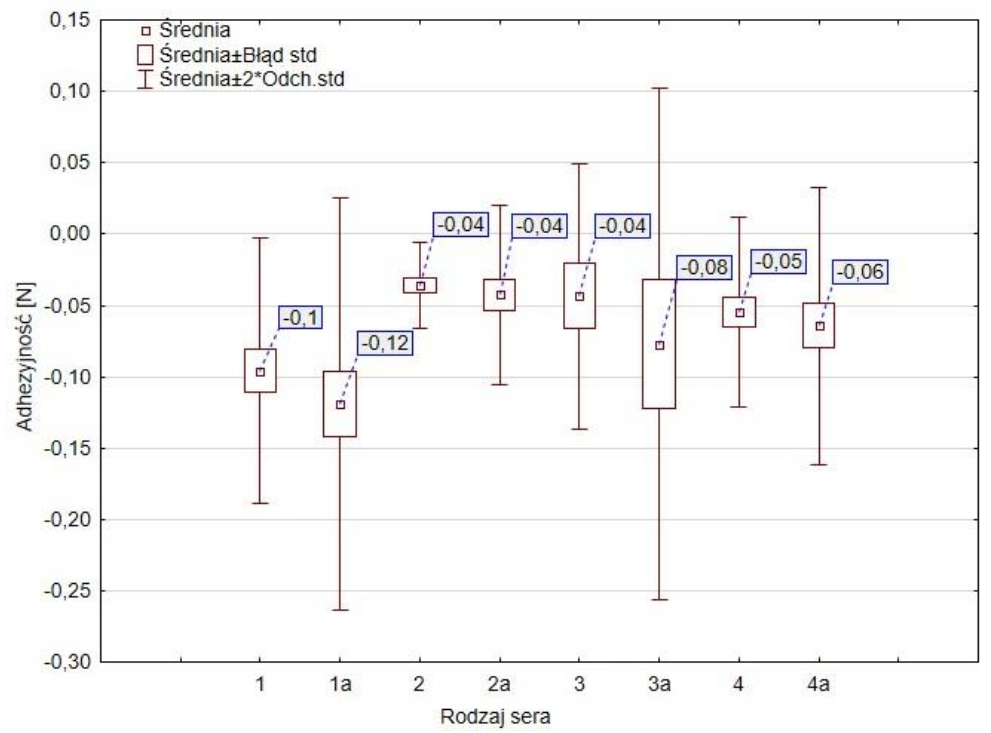

Rys. 9. Adhezyjność sera po mrożeniu: 1, 2, 3, 4-ściśnięcie pierwsze; 1a, 2a, 3a, 4a - ściśnięcie drugie

Po procesie mrożenia adhezyjność wszystkich serów klarowała się na podobnym poziomie i była niższa niż serów świeżych (rys. 9). Najmniejszą adhezyjność odnotowano dla sera białego podpuszczkowego naturalnego zakupionego w małym, tradycyjnym gospodarstwie rolnym, natomiast największą dla sera białego podpuszczkowego naturalnego zakupionego w supermarkecie. Tak jak w przypadku serów świeżych adhezyjność była większa podczas ściśnięcia drugiego. Zauważalne są także znaczne odchylenia standardowe, zwłaszcza dla serów po procesie mrożenia. Może być to skutkiem zmiany struktury serów lub niecałkowitego rozmrożenia produktu, co mogło zostać niezauważone przed dokonaniem pomiaru i wpływa na błąd pomiarowy. Kramek i Glibowski [2014], badając adhezyjność mieszanki inuliny i tłuszczu mlecznego, dowiedli, że im bardziej zwięzła jest struktura próbki, tym większa jest jej adhezyjność, zauważyli również, że wyższa temperatura badanej próbki powoduje jej większą adhezyjność. 


\section{Podsumowanie i wnioski}

Wykorzystując analizator tekstury, określono trzy cechy serów białych podpuszczkowych, takie jak twardość, jędrność oraz adhezyjność. Wyniki badań przeprowadzone na serach świeżych oraz na serach po dwumiesięcznym okresie mrożenia wykazały, że mrożenie wpływa na spadek wszystkich $\mathrm{z}$ badanych cech. Spośród badanych serów najtwardszy okazał się ser biały podpuszczkowy $\mathrm{z}$ dodatkiem czarnuszki, natomiast serem najbardziej miękkim był ser biały podpuszczkowy naturalny zakupiony w supermarkecie. Wykonany test jednostkowej siły cięcia i pracy cięcia jest analizą bardzo przydatną w przetwórstwie spożywczym, w szczególności przy porcjowaniu produktów spożywczych oraz doborze narzędzi tnących w maszynach. Test podwójnego ściskania wykazał, że ser biały podpuszczkowy naturalny wyprodukowany w małym, tradycyjnym gospodarstwie charakteryzował się największą jędrnością, natomiast najmniejszą jędrność wykazał ser biały podpuszczkowy naturalny zakupiony w supermarkecie. Zupełnie odwrotnie klarowała się sytuacja w badaniu adhezyjności. Serem o największej adhezyjności okazał się ser biały podpuszczkowy naturalny zakupiony w supermarkecie, natomiast najmniejszą adhezyjność odnotowano dla sera białego podpuszczkowego naturalnego wyprodukowanego w małym, tradycyjnym gospodarstwie. Odmienne wyniki dla poszczególnych rodzajów serów mogą wnikać ze zróżnicowania miejsc ich zakupu, a to przekłada się na rozbieżną jakość surowca, z jakiego zostały wyprodukowane. Wiadomo, iż wyższa jakość użytego do produkcji surowca, tj. mleka, w rezultacie daje wyższej jakości ser, charakteryzujący się lepszą teksturą. Duże odchylenie standardowe widoczne było dla próbek sera białego podpuszczkowego z dodatkiem czosnku oraz dla sera białego podpuszczkowego z dodatkiem czarnuszki, co wynikało z zakłóceń pomiaru z powodu znajdujących się w próbce dodatków.

\section{Bibliografia}

Andziak E., Tomala K., Sikora M., 2009. Wpływ warunków przechowywania na jakość jabłek Šampion. Post. Tech. Przetw. Spoż. 2, 27-35.

Bernaś E., Jaworska G., Maciejaszek I., Biernacka A., 2007. Wpływ obróbki wstępnej, zamrażania i zamrażalniczego składowania na teksturę pieczarek. ŻNTJ 5(54) 165-172.

Brodziak A., Król J., Barłowska J., 2017. Mleko i produkty mleczne źródłem składników biologicznie czynnych. Przem. Spoż. 71(10), 8-13.

Derengiewicz W., 1997. Technologia serów miękkich. Oficyna Wydawnicza „Hoża”, Warszawa.

Dolik K., Kubiak M., 2013. Instrumentalny test analizy profilu tekstury w badaniu jakości wybranych produktów spożywczych. Nauki Inż. Technol. 3(10), 35-44.

Dolik K., Kubiak M., Seńcio M., 2010. Analizator do pomiaru tekstury TMS-Pro - zasada działania i zastosowanie w badaniach produktów spożywczych. PAK 56(6), 636-639.

Gawęcki J., Pikul J., 2018. Produkty mleczne. Technologia i rola w żywieniu człowieka. Wyd. UP w Poznaniu. 
Knysz P., Gondek M., Pyz-Łukasik R., Ziomek M., Drozd Ł., Paszkiewicz W., Szkucik K., 2018. Skład chemiczny i wartość odżywcza regionalnych serów podpuszczkowych produkowanych metodą tradycyjną. Med. Weter. 2018, 74(10), 671-675.

Kramek K., Glibowski P., 2014. Właściwości tekstualne i reologiczne mieszaniny inuliny i tłuszczu mlecznego stabilizowanej lecytyną. ŻNTJ 6(97), 159-169.

Kwaśniewska-Karolak I., 2017. Wpływ zamrażalniczego przechowywania na zawartość witaminy C i wybrane cechy fizykochemiczne owoców papryki słodkiej (Capsicum annuum L.). ŻNTJ 1(110), 112-125.

Marzec A., 2007. Tekstura żywności. Przem. Spoż. 61(5), 6-10.

PN-ISO 11036:1999. Analiza sensoryczna - Metodologia - Profilowanie tekstury.

Półtorak A., 2007. Analiza zmian właściwości fizycznych półproduktów piekarskich i ich wpływ na teksturę gotowych produktów. Inż Rol. 5(93), 347-354.

Surówka K., 2002. Tekstura żywności i metody jej badania. Przem. Spoż. 56(10), 12-17.

Valli A., 2018. Twój domowy ser. Wyd. CeDeWu, Warszawa.

www.stablemicrosystems.com [data dostępu: 25.02.2020]. 


\author{
Aleksandra Noga ${ }^{1,2}$, Sybilla Nazarewicz ${ }^{1}$, Łukasz Papież ${ }^{1}$, Wiktor Bielawski ${ }^{1}$, \\ Cezary Piecyk ${ }^{1}$
}

\title{
Studia nad twardością liofilizatów $\mathrm{z}$ banana uzyskanych w zróżnicowanych warunkach
}

\author{
Studies on hardness of freeze-dried bananas obtained in different conditions
}

\begin{abstract}
Wstęp
Od wielu lat owoce są dla człowieka źródłem witamin, minerałów, błonnika oraz innych składników, które pośrednio lub bezpośrednio korzystnie oddziałują na zdrowie [Hung 2004]. Badania wykazują, że spożywanie odpowiedniej ilości owoców wiąże się ze zmniejszonym ryzykiem występowania chorób układu sercowo-naczyniowego, cukrzycy typu 2 oraz niektórych nowotworów (np. układu pokarmowego i oddechowego) [Mirmiran 2009].

Bardzo popularnym owocem jest banan (rodzina Musaceae-Musa). Uprawy bananów rozlokowane są w pasie klimatu tropikalnego i subtropikalnego [Koeppel 2005]. Owocem bananowca są pojedyncze, podłużne, mączyste jagody, skupione w kolbie lub kiści. Banany są bogatymi w składniki odżywcze owocami zawierającymi ok. $23 \%$ cukrów (w tym 2,3\% skrobi), $1 \%$ białek i 0,5\% thuszczów, witamin $\left(\mathrm{A}, \mathrm{B}_{1}, \mathrm{~B}_{2}, \mathrm{~B}_{6}\right.$ i C) oraz cennych składników mineralnych. Są źródłem potasu, który jest odpowiedzialny za stabilizację ciśnienia tętniczego. Dodatkowo banany mają właściwości regenerujące energię, ze względu na dużą zawartość cukrów (fruktozy, glukozy, sacharozy) [Karczmarczuk 2001]. Banan zawiera spore ilości pektyny, w wyniku czego podnosi poziom cholesterolu frakcji HDL, a obniża poziom cholesterolu LDL [Miazgowska i Mamok 2004]. Na świecie jest uprawianych ok. 80 różnych spożywczych gatunków bananów. Najbardziej znane, spotykane na sklepowych półkach, mają żółty kolor i słodkawy smak. Owoce bananowca mogą mieć także barwę fioletową lub czerwoną, a ich smak może w ogóle nie przypominać znanego nam banana [Moore i in. 2000].

Banany są powszechnie spożywane: w stanie surowym, jako świeże całe owoce, a także w postaci rozdrobnionej jako różnego rodzaju musy i sałatki owocowe. Ich przetwory wykorzystuje się jako dodatek do lodów, kaszek, bu-

\footnotetext{
${ }^{1}$ Studenckie Naukowe Koło Chłodnictwa, Katedra Biologicznych Podstaw Technologii Żywności i Pasz, Zakład Chłodnictwa i Energetyki Przemysłu Spożywczego, Wydział Inżynierii Produkcji, Uniwersytet Przyrodniczy w Lublinie

2 aaleksandra.noga.1997@gmail.com
} 
dyniów oraz odżywek i suplementów diet dla dzieci i innych produktów. Z plastrów niedojrzałych bananów wytwarza się chipsy bananowe pokryte najczęściej syropem glukozowo-fruktozowym, natomiast dojrzałe banany przeznacza się na susz [Friedrich i Zeller 2005].

Jedną z technik utrwalania żywności jest suszenie sublimacyjne wchodzące w skład technologii liofilizacji. Technologia ta znajduje coraz szersze zastosowanie w przemyśle spożywczym ze względu na bardzo wysoką jakość uzyskiwanych produktów i możliwość długotrwałego ich przechowywania w szerokim zakresie temperatur bez strat witamin, składników mineralnych, substancji biologicznie czynnych, białek, węglowodanów i tłuszczów.

Liofilizacja składa się z następujących etapów: zamrażanie, wstępne suszenie sublimacyjne oraz dosuszanie (suszenie desorpcyjne). Suszenie sublimacyjne polega na usuwaniu wody z zamrożonego produktu przez sublimację (zmianę lodu w parę wodną). Aby proces liofilizacji mógł prawidłowo przebiegać, niezbędne jest uzyskanie odpowiednich warunków ciśnieniowo-termicznych [Sun 2008]. Proces sublimacji może zajść jedynie wtedy, gdy temperatura i ciśnienie uzyskają wartość niższą niż parametry punktu potrójnego wody, dlatego też pierwszym etapem procesu jest odpowiednio głębokie zamrożenie surowca [Bednarski i Fiedurek 2007, Kondratowicz i Burczyk 2010]. Zamrażanie powoduje rozdzielenie jednorodnego roztworu wodnego wchodzącego w skład produktu na mieszaninę dwóch faz: kryształów lodu (stałej) i zagęszczonego międzykrystalicznego roztworu (ciekłej) o znacznie niższej temperaturze zamrażania niż woda. Przejście tego roztworu w stan stały wymaga obniżenia temperatury do $-40^{\circ} \mathrm{C}$ [Rahman i Perera 2007]. Bardzo ważnym parametrem technologicznym, który wpływa na teksturę produktu końcowego, jest szybkość zamarzania, która warunkuje kształt i wielkość powstałych struktur lodowych, co wiąże się z porowatością uzyskanych liofilizatów. Dynamika sublimacji lodu w obrębie większych struktur będzie wzmożona, co wywołuje efekt skrócenia czasu suszenia sublimacyjnego w drugim etapie liofilizacji [Witrowa-Rajcherat 2008]. Wytworzona w czasie suszenia sublimacyjnego para wodna przedostaje się przez pory po wysublimowanych kryształach lodu na zewnątrz poza suszony materiał. Para wodna po opuszczeniu surowca zostaje usunięta $z$ komory suszenia poprzez kondensację na chłodnej powierzchni kondensatora lodu lub w wyniku pochłaniania pary wodnej przez sorbenty [Ciurzyńska i Lenart 2010]. Etap właściwego suszenia sublimacyjnego kończy się w momencie, gdy na chłodniej powierzchni para wodna przestanie resublimować. Suszenie desorpcyjne jest ostatnim i często najdłuższym etapem liofilizacji. Powoduje usunięcie z surowca wody silnie związanej. Usuwana jest woda, która nie mogła ulec sublimacji na etapie procesu suszenia wstępnego. Dosuszanie przebiega w warunkach obniżonego ciśnienia $\mathrm{z}$ jednoczesnym podgrzaniem materiału do wartości granicznych (charakterystycznych indywidualnie dla każdego produktu) [Mayor i Sereno 2004]. Etap ten zależy głównie od efektywności sposobu doprowadzenia ciepła 
do produktu oraz intensywności usuwania pary wodnej z jego wewnętrznych warstw [Kramkowski 1998].

Suszenie sublimacyjne w porównaniu $\mathrm{z}$ konwencjonalnymi metodami trwa stosunkowo długo, zwykle od 12 nawet do 76 godz. i jest uzależnione głównie od temperatury i właściwości cieplnych produktu, wilgotności początkowej i końcowej surowca, wymiarów materiału oraz temperatury kondensatora lodu.

Na czas suszenia sublimacyjnego duży wpływ mają sposób i szybkość zamrażania. Powolne zamrażanie skutkuje powstawaniem dużych kryształów lodu, których szybkość sublimacji będzie większa. W przypadku szybkiego mrożenia materiału struktura lodu jest drobnokrystaliczna [Nawirska i in. 2009]. Znikoma zawartość wody zawartej w liofilizatach sprzyja długotrwałemu ich przechowywaniu bez zmiany właściwości fizycznych lub chemicznych. Metoda liofilizacji uznawana jest za najlepszy sposób usuwania wody z jednoczesnym zapewnieniem najwyższej jakości końcowej produktów [Krokida i Marinos-Kouris 2003].

Podczas procesu liofilizacji (np. truskawek, malin) następuje obniżenie objętości o ok. 8\%, co jest właściwością relatywnie niewielką $\mathrm{w}$ porównaniu $\mathrm{z}$ innymi metodami suszenia [Raghavan i Silveira 2001]. Temperatura procesu liofilizacji powinna być dobrana do rodzaju surowca. Niewłaściwe warunki suszenia mogą powodować zapadanie się struktury suszonych owoców. Decydującym parametrem procesu liofilizacji, przy którym produkty zachowują odpowiednie właściwości strukturalne, jest prowadzenie liofilizacji w temperaturze niższej niż przemiana szklista roztworu międzykrystalicznego [Shishehgarha i in. 2002].

Struktura liofilizatu kształtuje jego właściwości rehydratacyjne. Proces suszenia nie jest $\mathrm{w}$ pełni odwracalny, a rehydratacja przeprowadzana $\mathrm{w}$ różnych warunkach nie doprowadza do przywrócenia zawartości wody do poziomu sprzed liofilizacji [Krokida i Marinos-Kouris, 2003]. Przeprowadzone badania wykazały, że szybkość rehydratacji liofilizatów jest od 4 do 6 razy większa niż produktów suszonych konwekcyjnie [Ratti 2001]. Znaczący wpływ na przebieg procesu rehydratacji ma także temperatura prowadzenia procesu. Im wyższa temperatura, tym intensywniejszy przebieg wchłaniania wody i dyfuzji rozpuszczalnych składników suchej substancji. Obróbka wysokociśnieniowa w połączeniu z zamrażaniem przed etapem suszenia wstępnego powoduje zwiększenie szybkości uwadniania, wpływając korzystnie na zachowanie struktury i tekstury owoców oraz warzyw. Bardzo dobre właściwości rehydratacyjne wykazują banany i truskawki liofilizowane pod ciśnieniem niższym niż $80 \mathrm{~Pa}$ [Krokida i Marinos-Kouris 2003].

Celem pracy było określenie wpływu warunków zamrażania i sublimacyjnego suszenia na kształtowanie się twardości liofilizatów uzyskanych z bananów. Zakres pracy obejmował zamrażanie owoców banana w zróżnicowanych warunkach i ich suszenie sublimacyjne. 


\section{Material i metody}

Pomiary i badania przeprowadzono zgodnie ze schematem przedstawionym na rysunku 1.

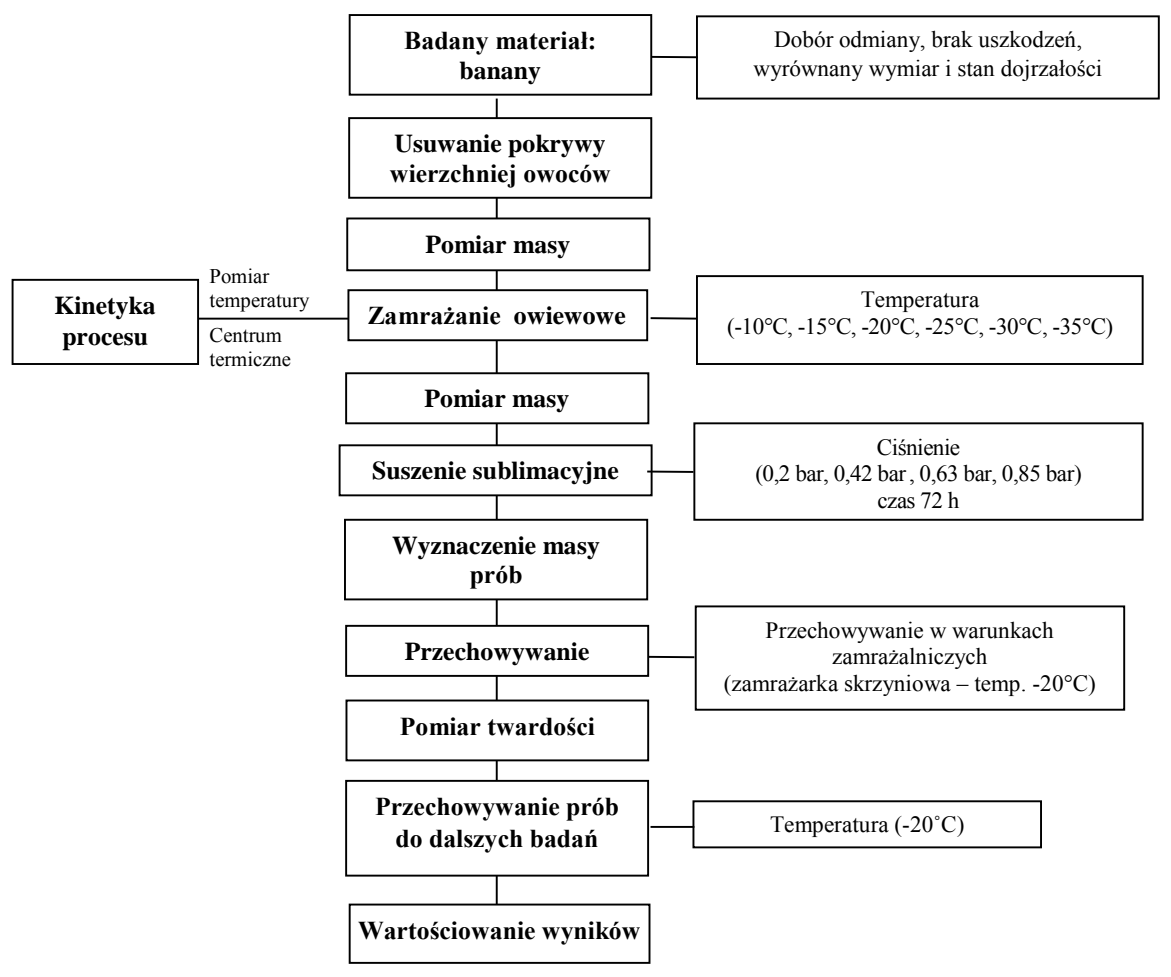

Rys. 1. Schemat blokowy przeprowadzonych badań

Do badań wykorzystano banany odmiany Cavendish, pochodzące od producentaz Kamerunu. Wybór materiału badawczego podyktowany został wysoką jakością, dużym stopniem jednolitości pod względem barwy i wymiarów oraz najniższym odsetkiem jakichkolwiek uszkodzeń.

Wykorzystany w badaniach materiał zaliczany był do klasy I. Nie wykazywał oznak porażenia mikroorganizmami ani szkodnikami.

Pomiar masy był wykonywany z dokładnością $\pm 0,01$ g za pomocą wagi laboratoryjnej RADWAG WLC. Masa pojedynczej próby wykorzystanej do badań wynosiła ok. 100 g. Pomiar wykonany został przed zamrażaniem surowca i po zakończonej liofilizacji.

Proces zamrażania realizowano w komorze klimatyzacyjnej Memmert CTC 256. Próby zamrażano w owiewie powietrza o temperaturze $-10,-15,-20,-25$, $-30 \mathrm{lub}-35^{\circ} \mathrm{C}$. 
W czasie procesu zamrażania dokonywano rejestracji zmian temperatury centrum termicznego bananów za pomocą rejestratora. Rejestrator dokonywał pomiaru temperatury z częstotliwością 20 pomiarów/min, a uzyskane dane umożliwiły opracowanie krzywych zamrażania, na podstawie których obliczono czas zamrażania, szybkość zamrażania oraz odczytano początkową temperaturę krioskopową przy wykorzystaniu metody stycznych Christodulo-Riutowa [Domin i Kluza 2006].

Czas zamrażania $\left(\mathrm{t}_{\mathrm{z}}\right)$ wyznaczono wg wzoru [Bøgh-Sørensen 2006]:

$$
\mathrm{t}_{\mathrm{z}}=\mathrm{t}_{\mathrm{z2}}-\mathrm{t}_{\mathrm{z} 1} \quad[\mathrm{~s}]
$$

$\mathrm{t}_{\mathrm{z} 1}$ - czas, po którym osiągnięto ustaloną temperaturę przed zamrażaniem [s], $\mathrm{t}_{\mathrm{z} 2}$ - czas, po którym osiągnięto zamierzoną temperaturę po zamrożeniu [s].

Szybkość zamrażania (v) wyznaczono wg wzoru:

$$
\mathrm{v}=\frac{\mathrm{s} \cdot 0,5}{\mathrm{t}_{\mathrm{z}}} \quad\left[\mathrm{mm} \cdot \mathrm{min}^{-1}\right]
$$

$\mathrm{s}$ - wymiar charakterystyczny próbki [mm],

$\mathrm{t}_{\mathrm{z}}-$ całkowity czas zamrażania $[\mathrm{min}]$.

Proces suszenia sublimacyjnego realizowano w suszarce sublimacyjnej Christ ALPHA 2-4 LD plus.

Pomiar masy umożliwiało określenie wilgotności materiału. Wilgotność bananów została wyznaczona zgodnie z normą PN-ISO1026:2000. Oznaczenie wykonano $\mathrm{z}$ dokładnością do $\pm 0,01 \mathrm{~g}$.

Wilgotność badanych bananów oznaczano z zależności:

$$
\mathrm{W}=\frac{\mathrm{m}_{\mathrm{p}}-\mathrm{m}_{\mathrm{k}}}{\mathrm{m}_{\mathrm{p}}} \times 100 \%
$$

$\mathrm{m}_{\mathrm{p}}$ - masa próby przed zamrożeniem [g],

$\mathrm{m}_{\mathrm{k}}$ - masa próby po zamrożeniu $[\mathrm{g}]$.

Pomiar tekstury przeprowadzono na bananach zgodnie z założeniami metodyki przy użyciu analizatora tekstury Brookfield LFRA Texture Analyzer, wykorzystując stożek o parametrach [Dobrzycki i Baryłko-Pikielna 1986]: kąt stożka $30^{\circ}$, prędkość przesuwu $0,5 \mathrm{~mm} / \mathrm{s}$, czas próbkowania 100 pomiarów/s, dokładność pomiaru $0,01 \mathrm{~N}$, minimalna siła kontaktu $0,01 \mathrm{~N}$, głębokość penetracji $5 \mathrm{~mm}$ oraz ilość powtórzeń 6 .

Wyniki opracowano, wykorzystując pakiet Microsoft Office. Wykresy tekstury oraz podstawowe obliczenia statystyczne w postaci odchylenia standardowego i średniej wartości siły nacisku wygenerowano przy użyciu programu TEXTURE Prolite. 


\section{Wyniki}

Pomiar masy wykonany przed i po suszeniu sublimacyjnym umożliwił obliczenie ilości wody usuniętej podczas procesu suszenia sublimacyjnego. Wartości przedstawiono jako udziały procentowe (tab. 1).

Tabela 1. Zmiana masy prób podczas suszenia sublimacyjnego

\begin{tabular}{|c|c|c|c|c|}
\hline Nr próby & $\begin{array}{c}\text { Masa przed } \\
\text { zamrożeniem } \\
{[\mathrm{g}]}\end{array}$ & $\begin{array}{c}\text { Masa po suszeniu } \\
\text { sublimacyjnym [g] }\end{array}$ & Ubytek masy [\%] & $\begin{array}{c}\text { Średni ubytek masy } \\
{[\%]}\end{array}$ \\
\hline 1 & 85 & 24,6 & 71,1 & \\
2 & 125 & 35,8 & 71,4 & \\
3 & 118 & 33,7 & 71,4 & 71,4 \\
4 & 111 & 31,7 & 71,4 & \\
5 & 112 & 31,9 & 71,5 & \\
6 & 101 & 28,4 & 71,9 & \\
\hline
\end{tabular}

Rejestracja temperatur poprzez sondy pomiarowe cyfrowego miernika temperatur umożliwiła opracowanie uśrednionych krzywych zamrażania badanych bananów, wyznaczenie początkowej temperatury krioskopowej oraz obliczenie całkowitej szybkości zamrażania surowca (rys. 2).

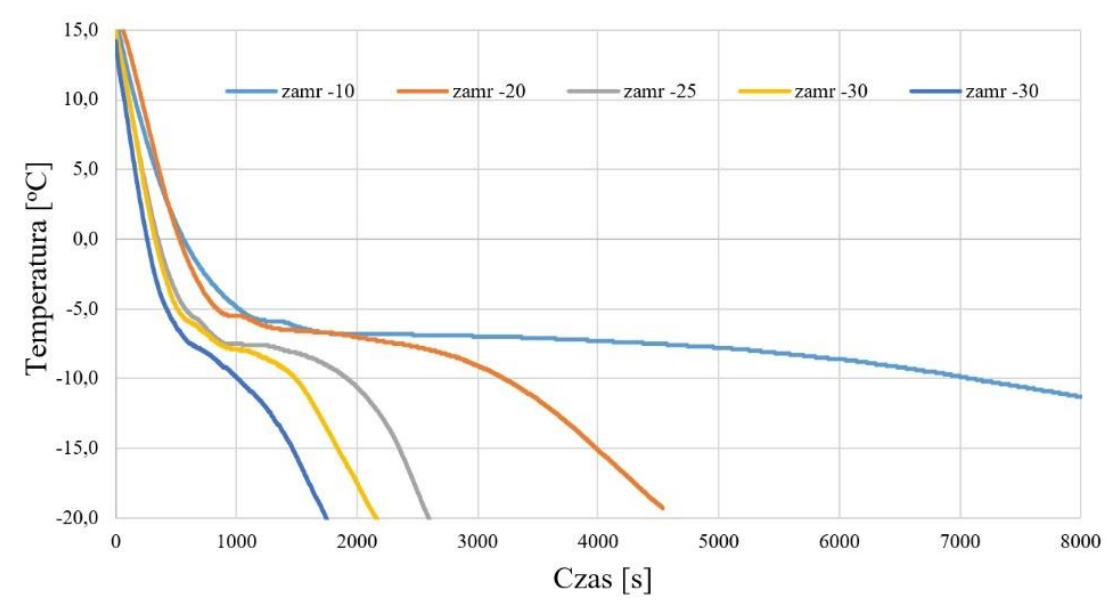

Rys. 2. Zależność temperatury od czasu zamrażania centrum termicznego bananów w różnych warunkach 
Tabela 2. Odczytana krioskopowa temperatura początkowa i szybkość zamrażania bananów

\begin{tabular}{|c|c|c|}
\hline $\begin{array}{c}\text { Temperatura środowiska } \\
\text { zamrażającego } \\
{\left[{ }^{\circ} \mathrm{C}\right]}\end{array}$ & $\begin{array}{c}\text { Początkowa temperatura } \\
\text { krioskopowa } \\
{\left[{ }^{\circ} \mathrm{C}\right]}\end{array}$ & $\begin{array}{c}\text { Szybkość zamrażania } \\
{[\mathrm{mm} / \mathrm{h}]}\end{array}$ \\
\hline-10 & $-6,7$ & 10,3 \\
-15 & $-6,7$ & 15,1 \\
-20 & $-6,7$ & 22,5 \\
-25 & $-6,7$ & 36,9 \\
-30 & $-6,7$ & 47,9 \\
-35 & $-6,7$ & 66,6 \\
\hline
\end{tabular}

Wyznaczona początkowa temperatura krioskopowa badanych bananów wyniosła $-6,7 \mathrm{C}$ (tab. 2).

Największą szybkość zamrażania odnotowano dla prób zamrażanych w temperaturze $-35^{\circ} \mathrm{C}$, a najniższą w temperaturze $-10^{\circ} \mathrm{C}$ i wyniosły one odpowiednio $66,6 \mathrm{~mm} / \mathrm{h}$ i $10,3 \mathrm{~mm} / \mathrm{h}$.

Pomiar tekstury pozwolił na odczytanie maksymalnej siły nacisku w badaniu penetrometrycznym. Najwyższą siłę wynoszącą $51,6 \mathrm{~N}$ odnotowano w przypadku pomiaru twardości prób zamrażanych owiewowo $\mathrm{w}-35^{\circ} \mathrm{C}$ i suszonych sublimacyjnie w ciśnieniu $85 \mathrm{~Pa}$. Najniższą twardość o wartości 13,4 N zaobserwowano dla prób zamrażanych $\mathrm{w}$ owiewie powietrza o temperaturze $-10^{\circ} \mathrm{C}$ i suszonych sublimacyjnie pod ciśnieniem $20 \mathrm{~Pa}$. Zmiana temperatury i ciśnienia procesu liofilizacji wpływa na twardość liofilizowanych bananów. Największą twardość

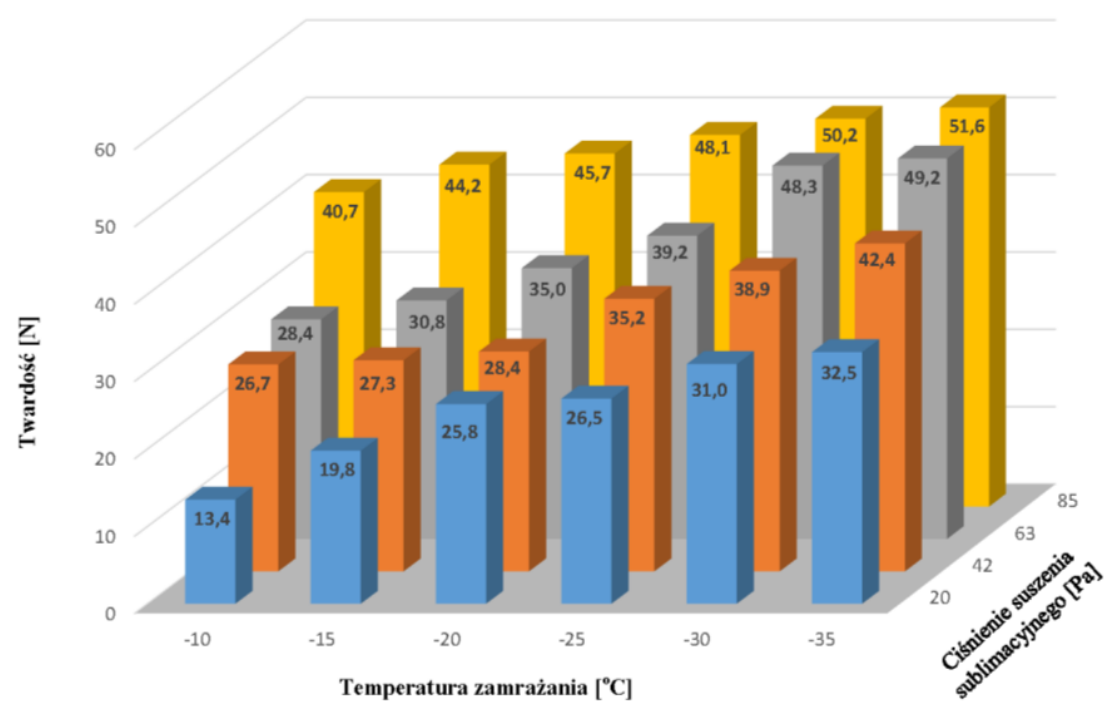

Rys. 3. Zależność twardości od warunków liofilizacji prób badanej odmiany bananów 
(48,3-51,6 N) odnotowano dla prób bananów zamrażanych w temperaturach od $-35 \mathrm{do}-25^{\circ} \mathrm{C}$ i suszonych pod ciśnieniem $85 \mathrm{~Pa}$, zaś najniższą w przypadku bananów zamrażanych $\mathrm{w}-15^{\circ} \mathrm{C}$ i suszonych pod ciśnieniem $20 \mathrm{~Pa}$, i wynosiła ona 13,28 N (rys. 3).

Największy wzrost twardości zaobserwowano w przypadku prób suszonych sublimacyjnie $\mathrm{w} 20 \mathrm{~Pa}$ i wcześniej zamrażanych $\mathrm{w}-10^{\circ} \mathrm{C} \mathrm{w}$ porównaniu z próbami zamrażanych $\mathrm{w}-35^{\circ} \mathrm{C}$, których twardość wyniosła odpowiednio $13,4 \mathrm{~N}$ i $32,5 \mathrm{~N}$ (rys. 3).

\section{Wnioski}

Przeprowadzone badania i analiza ich wyników umożliwiły sformułowanie następujących wniosków:

1. Wartość ciśnienia suszenia sublimacyjnego jest parametrem kształtującym twardość liofilizatów wytworzonych z owoców banana. Niższe ciśnienie suszenia zapewnia mniejszy skurcz i niższą twardość liofilizatów banana. Wyższe ciśnienie sublimacyjnego suszenia wiąże się ze wzrostem twardości i większą deformacją liofilizatów.

2. Szybkość zamrażania wstępnego w procesie liofilizacji bananów jest powiązana $\mathrm{z}$ właściwościami reologicznymi uzyskanych produktów. Jest to skorelowane $\mathrm{z}$ rodzajem tworzonej sieci krystalicznej powstającej w różnych warunkach zamrażania. Liofilizaty bananów zamrażanych wstępnie $\mathrm{z}$ większymi szybkościami wykazywały większą twardość w każdym wariancie suszenia.

3. Zbyt zaawansowany proces dojrzałości dyskwalifikuje banany z ich zastosowania do obróbki liofilizacyjnej. Przyczyną jest utrata struktury miąższu, który zasklepia się i uniemożliwia odprowadzenie pary wodnej z sublimowanych kryształów lodu umiejscowionych w wewnętrznych warstwach produktu.

\section{Bibliografia}

Bednarski W., Fiedurek J., 2007. Podstawy biotechnologii przemysłowej. WNT, Warszawa 2007. Bøgh-Sørensen L., 2006. Recommendations for the processing and handling of frozen foods. IIR Book, IIF-IIR, France.

Ciurzyńska A., Lenart A., 2010. Structural impact of osmotically pretreated freeze-dried strawberries on their mechanical properties. Int. J. Food Prop. 13(5), 1134-1149, https://doi.org/10.1080/10942910903013134

Dobrzycki J., Baryłko-Pikielna N., 1986. Instrumentalne metody pomiaru tekstury żywności. IŻŻ, Warszawa, 22-23.

Domin M., Kluza F., 2006. Wpływ warunków blanszowania na zmianę wybranych właściwości fizycznych żółtej fasoli szparagowej przeznaczonej do mrożenia. Acta Sci. Pol., Technica Agraria 5(1), 3-17.

Friedrich J., Zeller H., 2005. Herkunft, Diversität und Züchtung der Banane und kultivierter Zitrusarten (Origin, diversity and breeding of banana and cultivated citrus) (PDF). J. Agric. Rural Dev. Trop. Subtrop, suppl. 81 (in German) [data dostępu: 03.12.2015]. 
Hung H.C., 2004. Fruit and vegetable intake and risk of major chronic disease. J. Nat. Can. Inst. 96(21), 1577-1584. DOI: 10.1093/jnci/djh296.

Karczmarczuk R., 2001. Co warto wiedzieć o bananach. Wiad. Zielar. 43, 6, 16-17.

Koeppel D., 2005. Can This Fruit Be Saved? Pop. Sci. 267(2), 60-70.

Kondratowicz J., Burczyk E., 2010. Technologiczne aspekty procesu liofilizacji. Chłodnictwo 4, $54-59$.

Kramkowski R., 1998. Analiza suszenia sublimacyjnego wybranych surowców spożywczych. Zesz. Nauk. AR we Wrocławiu 333, 120-135.

Krokida M.K., Marinos-Kouris D., 2003. Rehydration kinetics of dehydrated products. J. Food Eng. 57, 1-7. http://doi.org/10.1016/S0260-8774(02)00214-5

Mayor L., Sereno A.M., 2004. Modelling shrinkage during convective drying of food material: a review. J. Food Eng. 18, 373-386. http://doi.org/ 10.1016/S0260-8774(03)00144-4

Miazgowska T., Mamok H., 2004. Banany. Zdrowa Żywność, Zdrowy Styl Życia 4, 42-45.

Mirmiran P., 2009. Fruit and vegetable consumption and risk factors for cardiovascular disease. Metabolism 58(4), 460-468. https://doi.org/10.1016/j.metabol.2008.11.002

Moore B., Qi B., Keith G., Orchard J., 2000. Effect of cooking on banana and plantain texture. J. Agric. Food Chem. 48(9), 4221-4226. https://doi.org/10.1021/jf991301z

Nawirska A., Figiel A., Kucharska A.Z., Sokół-Łętowska A., Biesiada A., 2009. Drying kinetics and quality parameters of pumpkin slices dehydrated using different methods. J. Food Eng. 94, 14-20. http://doi.org/10.1016/j.jfoodeng.2009.02.025

PN-ISO 1026:2000. Produkty owocowe i warzywne. Oznaczanie zawartości suchej substancji w wyniku suszenia przy obniżonym ciśnieniu i zawartości wody w wyniku destylacji azeotropowej.

Raghavan G.S.V., Silveira A.M., 2001. Shrinkage characteristics of strawberries osmotically dehydrated in combination with microwave drying. Dry. Technol. 2(19), 405-414. https://doi.org/10.1081/DRT-100102913

Rahman M.S., Perera C.O., 2007. Handbook of food preservation, $2^{\text {nd }}$ ed. CRS Press, Boca Ration, $125-130$.

Ratti C., 2001. Hot air and freeze drying of high-value foods: a review. J. Food Eng. 49, 311-320. https://doi.org/10.1016/S0260-8774(00)00228-4

Shishehgarha F., Malkhlouf J., Ratti C., 2002. Freeze-drying characteristics of strawberries. Dry. Technol. 20(1), 131-145. https://doi.org/10.1081/DRT-120001370

Sun W., 2008. The cavitation-implosion hypothesis of freeze drying damage to biological materials. Cryobiology 12, 57-60. https://doi.org/10.1016/j.cryobiol.2008.10.087

Witrowa-Rajcherat D., 2008. Suszarki sublimacyjne w żywności. Przem. Spoż. 4, 14-20. 
Łukasz Papież ${ }^{1,2}$, Sybilla Nazarewicz ${ }^{1}$, Aleksandra Noga ${ }^{1}$, Wiktor Bielawski ${ }^{1}$, Cezary Piecyk ${ }^{1}$

\title{
Projekt i zestawienie stanowiska do pomiaru współczynnika wnikania ciepła
}

Desing and summary of results for measuring heat transfer

\begin{abstract}
Wstęp
Ciepło jest jednym ze sposobów przekazywania energii bez towarzyszącej temu zjawisku równoczesnej wymiany masy. Mechanizmem wywołującym przepływ ciepła jest różnica temperatury (potencjału termicznego) pomiędzy punktami przestrzeni (obiektu, układu itp.) [Wiśniewski i Wiśniewski 1979, Zhou i wsp. 2016, Lienhard i Lienhard 2019]. Z temperaturą i ciepłem powiązana jest druga zasada termodynamiki. Zgodnie z nią ciepło przemieszcza się od punktu o wyższej temperaturze do punktu o niższej temperaturze [Pudlik 2012, Sheikholeslami i wsp. 2015]. Według innej definicji ciepło jest energią przekazywaną z jednego układu do drugiego w wyniku istniejącej między nimi różnicy potencjałów. Ilość ciepła (Q), jaka uległa wymianie w obiekcie o masie (m), od temperatury początkowej do końcowej $\left(\mathrm{T}_{2}-\mathrm{T}_{1}\right)$, której nie towarzyszyła zmiana stanu skupienia, obliczana jest z wykorzystaniem zależności [Sheikholeslami i wsp. 2016, Zhou i wsp. 2016]:
\end{abstract}

$$
\mathrm{Q}_{1-2}=\mathrm{m} \cdot \mathrm{c}_{\mathrm{sr}} \cdot\left(\mathrm{T}_{2}-\mathrm{T}_{1}\right)
$$

gdzie:

$\mathrm{Q}$ - ilość ciepła $[\mathrm{J}]$,

$\mathrm{m}$ - masa $[\mathrm{kg}]$,

$\mathrm{c}_{\text {sr }}-$ średnie ciepło wł. $\mathrm{J} / \mathrm{kgK}, \mathrm{J} / \mathrm{kg}^{\circ} \mathrm{C}$,

$\mathrm{T}_{1}, \mathrm{~T}_{2}-$ temp. [K lub $\left.{ }^{\circ} \mathrm{C}\right]$

\footnotetext{
${ }^{1}$ Studenckie Naukowe Koło Chłodnictwa, Katedra Biologicznych Podstaw Technologii Żywności i Pasz, Zakład Chłodnictwa i Energetyki Przemysłu Spożywczego, Wydział Inżynierii Produkcji, Uniwersytet Przyrodniczy w Lublinie

${ }^{2}$ lukasz.papierz@wp.pl
} 
Obowiązująca obecnie teoria ciepła opracowana została w latach 40. XIX w. i jest autorstwa znanego brytyjskiego badacza Jamesa Joule'a. Jego doświadczenie udowodniło, że zniknięcie lub powstawanie ustalonej ilości ciepła nieprzerwanie powiązane jest ze zniknięciem lub pojawieniem się adekwatnej ilości energii mechanicznej [Atkins 2001, Lienhard i Lienhard 2019].

Opracowane prawo Joule'a brzmi: ilość wytworzonego przez prąd elektryczny ciepła jest proporcjonalna do oporu danego przewodnika i kwadratu natężenia prądu oraz czasu jego przepływu [Lienhard i Lienhard 2019]. Na cześć badacza jednostka miary energii lub ciepła została nazwana dżulem i jest stosowana w Międzynarodowym Układzie Jednostek i Miar SI. Definicja jednostki energii, jaką jest dżul, obejmuje jednostki pracy, energii oraz ciepła w układzie. Jeden dżul to praca wykonana przez siłę o wartości $1 \mathrm{~N}$ przy przesunięciu punktu przyłożenia siły o $1 \mathrm{~m}$ w kierunku równoległym do kierunku działania siły [BIPM 2019].

Powszechnie stosowaną w Polsce skalą temperatury jest skala Celsjusza $\left[{ }^{\circ} \mathrm{C}\right]$. Początkiem skali jest temperatura zamarzania wody $\left(0^{\circ} \mathrm{C}\right)$ pod ciśnieniem normalnym, a drugim punktem odniesienia jest temperatura wrzenia wody $\left(100^{\circ} \mathrm{C}\right)$ w ciśnieniu normalnym. Aktualną jednostką temperatury, która jest wykorzystywana w naukach ścisłych, jest kelwin [1 K]. Skala Kelwina jest ściśle powiązana ze skalą Celsjusza, zachowuje taką samą działkę elementarną. Różni je punkt początkowy skali. Skala Kelwina rozpoczyna się od temperatury zera bezwzględnego. Skalę Celsjusza i Kelwina opisuje zależność [Michalski i Eckerdorf 1969, Wiśniewski i Wiśniewski 1979, Staniszewski 1986]:

$$
\mathrm{T}_{\mathrm{k}}=\mathrm{t}_{\mathrm{C}}+273,15 \cdot \mathrm{T}_{\mathrm{k}}[\mathrm{K}]
$$

gdzie:

$\mathrm{T}_{\mathrm{k}}$ - temp. bezwzględna wyrażona w skali Kelwina, $\mathrm{t}_{\mathrm{C}}$ - temp. wyrażona w skali Celsjusza.

Strumień ciepła Q [W] jest to wielkość charakteryzująca natężenie przepływu (wymiany) ciepła, czyli pochodna po czasie ilości ciepła przepływającej prostopadle przez analizowany przekrój [Kostkowski 1986].

$$
\mathrm{Q}=\frac{\mathrm{dQ}}{\mathrm{dt}}
$$

W przypadku stałej prędkości (ustalonego) przepływu ciepła wzór na obliczenie jego strumienia przyjmuje postać:

$$
Q=\frac{Q}{t}
$$


Gęstość strumienia cieplnego q jest to ilości wymienionego ciepła w warunkach ustalonych, w odpowiednim czasie, przez określoną powierzchnię i przy równomiernym przenoszeniu ciepła przez całą badaną powierzchnię biorącą udział w wymianie ciepła $\left[\mathrm{W} / \mathrm{m}^{2}\right]$. Gęstość strumienia ciepła jest to parametr opisujący strumień ciepła wymieniany na jednostce powierzchni. Określa się go stosunkiem strumienia ciepła pola powierzchni, na którym dochodzi do wymiany ciepła [Pudlik 2012, Lienhard i Lienhard 2019]:

$$
\mathrm{q}=\frac{\mathrm{Q}}{\mathrm{A}}\left[\mathrm{W} / \mathrm{m}^{2}\right]
$$

Przewodzenie ciepła jest jednym z trzech sposobów wymiany ciepła. Energia cieplna przepływa spontanicznie z punktów lub ciał o wyższych temperaturach do ciał lub punktów o niższej temperaturze, aż nastąpi wyrównanie potencjałów termicznych. Im większa różnica temperatur, tym większy strumień ciepła. Przewodzenie ciepła zachodzi głównie w ciałach stałych i pomiędzy ciałami stałymi na granicy ich styku. Najlepsze warunki przewodzenia ciepła zachodzą w ciałach stałych, natomiast $\mathrm{w}$ cieczach $\mathrm{i}$ gazach tylko w pewnych warunkach. Takie zjawisko zostało opisane wzorem przez Fouriera [Sheikholeslami i wsp. 2015]:

$$
q=-\lambda \cdot \operatorname{gradt}=-\lambda \frac{\varphi \mathrm{t}}{\varphi \mathrm{n}}=-\lambda \cdot \nabla \mathrm{t}\left[\mathrm{W} / \mathrm{m}^{2}\right]
$$

Występujący we wzorze znak minus $-\lambda$ jest przeciwny do wektora gradientu temperatury, ponieważ spadek jednostkowego strumienia cieplnego jest proporcjonalny do gradientu temperatury [Kmieć 2005].

Wielkością fizyczną charakteryzującą daną substancję pod kątem przewodzenia ciepła jest współczynnik przewodzenia ciepła, inaczej nazywany współczynnikiem przewodności cieplnej $\lambda[\mathrm{W} / \mathrm{mK}]$. Zależny jest od wewnętrznej struktury substancji, jej gęstości i temperatury [Pudlik 2012].

Konwekcja jest procesem przekazywania energii cieplnej pomiędzy obiektami lub środowiskami, z których jeden jest ciałem stałym, a drugi płynem. Wnikanie, inaczej przejmowanie ciepła, zachodzi pomiędzy powierzchnią ścianki, a otaczającą ją cieczą lub gazem. Zbliżając się do powierzchni wymiany, zmniejsza się lub całkowicie ustaje ruch konwekcyjny w kolejnych warstwach laminarnych. Można wymienić konwekcję swobodną i wymuszoną. Konwekcja wymuszona przejawia się wtedy, gdy ruch płynu następuje przez wymuszony jego przepływ (praca wentylatorów, pomp, wiatru itp.), swobodna konwekcja, inaczej naturalna, charakteryzuje się ruchem przyściennych warstw płynu, który spowodowany jest naturalnymi grawitacyjnymi jego ruchami wywołanymi schładzaniem lub ogrzewaniem [Pudlik 2012, Sheikholeslamia i wsp. 2016].

Zwiększona konwekcyjna wymiana ciepła daje możliwość oszczędzenia energii w celu zmniejszenia kosztów [Kassai i Simonson 2014, Zhou i wsp. 2016]. 
Przenoszenie konwekcyjne ciepła zachodzi wtedy, gdy płyn ma kontakt z ciałem stałym. Kiedy płyn przemieszcza się przy powierzchni wymiany ciepła powstaje siła napędowa. Jeśli zachodzący ruch wynika $\mathrm{z}$ gęstości płynu i jest spowodowany różnicami temperatury będzie nazywany konwekcją naturalną [Hamadi i Mohsein 2017].

Konwekcja swobodna powstaje podczas zmasowanego ruchu płynu i jest zjawiskiem wymiany ciepła. Występująca w konwekcji siła wyporu jest skutkiem zmiany temperatury i gęstości przylegającego płynu. Czynniki wpływające na konwekcję to: własność płynu, prędkość przepływu płynu, powierzchnia wymiany ciepła, wymiary i kształt obiektów wymiany. Konwekcję wymuszoną i swobodną określa prawo Newtona (1701 r.), które można przedstawić w formie:

$$
\mathrm{q}=\alpha \cdot\left(\mathrm{t}_{\mathrm{w}}-\mathrm{t}_{\mathrm{p}}\right)\left[\mathrm{W} / \mathrm{m}^{2}\right]
$$

gdzie:

$$
\begin{aligned}
& \mathrm{q}-\text { gęstość strumienia ciepła }\left[\mathrm{W} / \mathrm{m}^{2}\right], \\
& \alpha \text { - współczynnik wnikania ciepła }\left[\mathrm{W} / \mathrm{m}^{2} \mathrm{~K}\right], \\
& \mathrm{t}_{\mathrm{w}} \text { - temperatura powierzchni ścianki (ciała stałego) }\left[{ }^{\circ} \mathrm{C}\right] \text {, } \\
& \mathrm{t}_{\mathrm{p}}-\text { temperatura płynu }\left[{ }^{\circ} \mathrm{C}\right] .
\end{aligned}
$$

Prawo Izaaka Newtona mówi: szybkość, z jaką układ stygnie, jest proporcjonalna do różnicy temperatur pomiędzy układem a otoczeniem [Lienhard i Lienhard 2019]. W równaniu Newtona problem stanowi określenie wartości wnikania ciepła $\alpha, \mathrm{z}$ powodu skomplikowanego mechanizmu konwekcji. Występują różne jej rodzaje, np. konwekcja podczas przepływu wymuszonego lub konwekcja podczas wrzenia. Jest to utrudnienie uniemożliwiające analizę zjawisk konwekcji w jednolity sposób. Dla każdego rodzaju konwekcji wybiera się osobne zbiory wielkości uzależnione od współczynnika wnikania ciepła $\alpha$. Wnikanie ciepła przy przepływie burzliwym można zaobserwować, kiedy przepływ jednoznacznie ma określoną (daną lub złożoną) średnią prędkość. Taki przepływ można zaobserwować podczas pracy wentylatora lub dmuchawy [Staniszewski 1986, Nadziakiewicz 1998].

Przedstawienie właściwości fizycznych płynu wyznacza się dla średniej temperatury płynu określanej z zależności:

$$
\mathrm{T}_{\mathrm{sr}}=\frac{\mathrm{T}_{\mathrm{wl}}-\mathrm{T}_{\mathrm{wyl}}}{2}
$$

gdzie:

$\mathrm{T}_{\mathrm{wl}}$ - temperatura płynu na wlocie do rury $[\mathrm{K}]$,

$\mathrm{T}_{\mathrm{wyl}}-$ temperatura płynu na wylocie $\mathrm{z}$ rury $[\mathrm{K}]$. 
Aby uzyskać współczynnik wnikania dla warstwy płynu bezpośrednio przylegającego do powierzchni wymiany ciepła, należy skorzystać z prawa Fouriera i prawa Newtona. Prawo Fouriera opisuje przenoszenie ciepła tylko przez przewodzenie [Pudlik 2012]. Po połączeniu tych zależności powstaje wzór:

$$
\alpha=\frac{\left(-\frac{\varphi \mathrm{t}}{\varphi n}\right)_{w}}{t_{w}-t_{f}} \cdot \lambda
$$

Przybliżenie jest jednym ze wzorów stosowanym w tej metodzie pomiaru. Najważniejszym elementem jest zachowanie prawidłowych wielkości między oporami cieplnymi. Nie jest ważna ilość warstw i kształt przegród [Wiśniewski i Wiśniewski 1979, Kostkowski 1986].

\section{Cel i zakres pracy}

Celem pracy było zaprojektowanie, dobranie elementów składowych i skonstruowanie stanowiska do pomiaru współczynnika wnikania ciepła $\alpha$. W zakres pracy wchodzi dokonanie przeglądu stanu aktualnej wiedzy z zakresu pomiarowych metod wyznaczania współczynnika wnikania ciepła $\alpha$ oraz dokonanie pomiarów za pomocą opracowanego zestawu wraz z weryfikacją uzyskanych wyników z danymi literaturowymi.

\section{Materiał oraz metodyka pomiarów}

Dokonano analizy rynkowej oferty sond pomiaru strumienia ciepła i termopar, na podstawie której skonstruowano stanowisko pomiarowe umożliwiające wyznaczenie współczynnika wnikania ciepła (rys. 1).

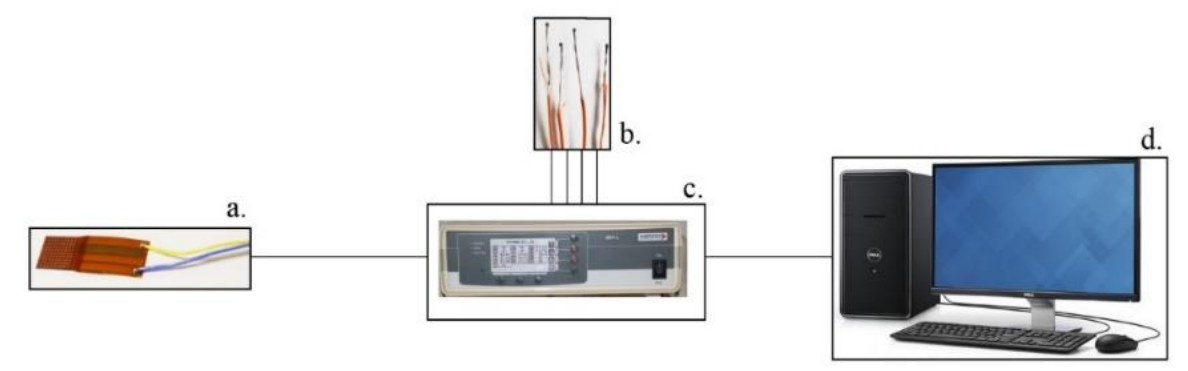

Rys. 1. Schemat stanowiska pomiarowego: a - sonda pomiaru strumienia ciepła, $b$ - termopary pomiarowe $\mathrm{NiCrNi}$, c - cyfrowy rejestrator MPI-L; komputer klasy PC 
Konstrukcję stanowiska do pomiaru współczynnika wnikania ciepła oparto na sondach do pomiaru strumienia ciepła o wymiarach powierzchni pomiarowej $1 \times 1 \mathrm{~cm}$, których producentem jest firma Sequoia. Pomiaru temperatury badanej powierzchni i otoczenia dokonywano z wykorzystaniem termopar NiCrNi typu T.

Sondy podłączono do analizatora napięcia MPI-L, który za pomocą systemu Uniwersal Serial Bus i oprogramowania sterującego współpracował z zestawem komputerowym klasy PC.

Jako materiał wzorcowy do badań wykorzystano płytę miedzianą, marchew, buraka ćwikłowego oraz żółty ser. Czujnik pomiaru strumienia ciepła przytwierdzano do powierzchni badanego materiału za pomocą pasty termoprzewodzącej. Termoparę rejestrującą temperaturę powierzchni umieszczano bezpośrednio pod powierzchnią wymiany ciepła, przebijając na wskroś próbę. Termoparę rejestrującą temperaturę otoczenia umieszczano w przestrzeni oddalonej o $50 \mathrm{~cm}$ od próby (rys. 2).

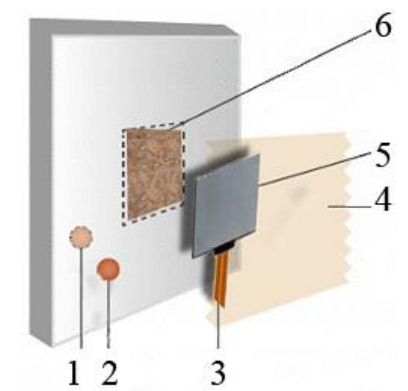

Rys. 2. Rozmieszczenie elementów pomiarowych: 1 - termopara pomiaru temperatury powierzchni próby, 2 - termopara pomiaru temperatury środowiska schładzającego, 3 - czujnik pomiaru strumienia ciepła, 4 - film termoprzewodzący; 5 - powierzchnia pomiarowa czujnika, 6 - miejsce usytuowania czujnika strumienia ciepła

Aby zachować jednorodność warunków, pomiary prowadzono, schładzając próby $\mathrm{w}$ zamrażarce skrzyniowej $\mathrm{w}-30^{\circ} \mathrm{C}$, w warunkach konwekcji swobodnej. Temperatura początkowa prób wynosiła $15^{\circ} \mathrm{C}$. Pomiaru temperatury i strumienia ciepła dokonywano na pionowej ścianie próby w 5 punktach, za wynik końcowy przyjęto średnią z tych pomiarów.

Wyznaczenie współczynnika wnikania ciepła przeprowadzono, wykorzystując równanie Newtona [Lienhard i Lienhard 2019]:

$$
\mathrm{Q}_{\mathrm{h}}=\alpha \cdot \mathrm{A} \cdot\left(\mathrm{T}_{\mathrm{w}}-\mathrm{T}_{\mathrm{f}}\right)
$$

gdzie:

$\mathrm{Q}_{\mathrm{h}}-$ strumień ciepła,

A - pole powierzchni,

$\mathrm{T}_{\mathrm{w}}$ - temperatura powierzchni próby,

$\mathrm{T}_{\mathrm{f}}$ - temperatura środowiska schładzającego. 
Zależność Newtona przekształcono do postaci:

$$
\alpha=\frac{Q_{h}}{A \cdot\left(T_{w}-T_{f}\right)}
$$

Wyznaczoną wartość współczynnika wnikania ciepła odniesiono do czasu i różnicy temperatur przy pomiarze miejscowym.

\section{Wyniki pomiarów}

Dane z pomiarów dokonywanych na zamrażanych w warunkach konwekcji swobodnej obiektach przetransponowano do pliku tekstowego, a następnie do arkusza kalkulacyjnego Excel, w którym dokonano niezbędnych przeliczeń i podstawien. Pomiary dokonane $\mathrm{z}$ wykorzystaniem czujnika strumienia ciepła przeliczono do postaci jednostek właściwych tego zjawiska. Wyniki pomiaru wartości miejscowego (chwilowego) współczynnika wnikania poddano interpretacji graficznej i podstawowej analizie statystycznej polegającej na doborze linii trendu z równaniem opisującym jej przebieg oraz uzyskanym współczynnikiem korelacji (rys. 3 i 4 ).
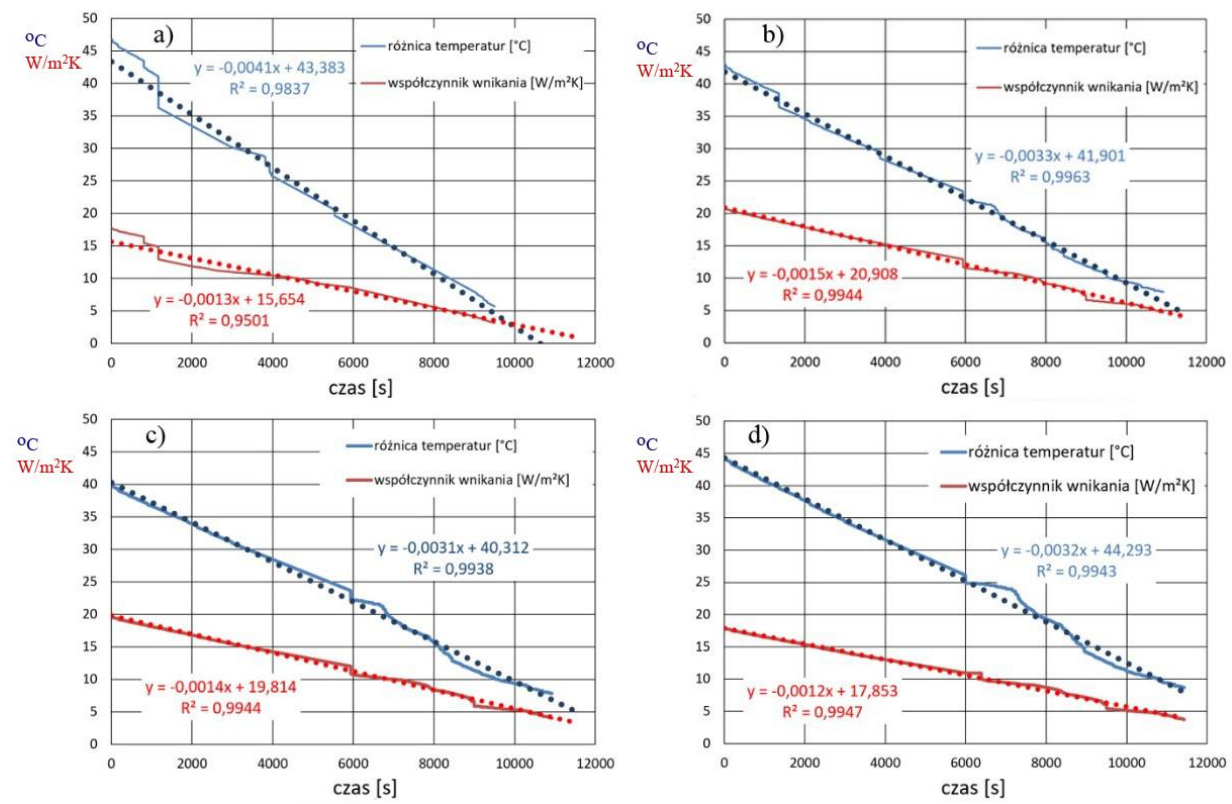

Rys. 3. Kształtowanie się współczynnika wnikania ciepła $\alpha$ i różnicy temperatury pomiędzy powierzchnią a środowiskiem chłodzącym podczas schładzania: a) płyty miedzianej, b) plastrów marchwi, c) plastrów buraka czerwonego, d) bloku sera żółtego 
Interpretacji wyników dokonano w układzie wartość-czas i współczynnik wnikania-różnica temperatur, uzyskując na ich podstawie wykresy umożliwiające odczytanie chwilowego współczynnika wnikania. Zarówno różnica temperatur pomiędzy powierzchnią obiektu a środowiskiem schładzającym, jak i wartość współczynnika wnikania miały charakter prostoliniowy z bardzo wysokim współczynnikiem korelacji. Wysokie wartości współczynnika korelacji $\mathrm{R}^{2}$, osiągające wartości od $0,9837 \mathrm{w}$ przypadku schładzania płytki miedzianej do 0,9963 podczas schładzania plastrów marchwi, świadczą o prawidłowym doborze proponowanego modelu (rys. 3 i 4 ).

Zestawione wyniki w układzie współczynnik wnikania-różnica temperatur również poskutkowały otrzymaniem prostoliniowych zależności o bardzo wysokim współczynniku korelacji. Najniższy odnotowano w przypadku zamrażania płytki miedzianej - wynosił 0,9786, najwyższy zaś dla plastra buraka ćwikłowego - wynosił 0,9963 .
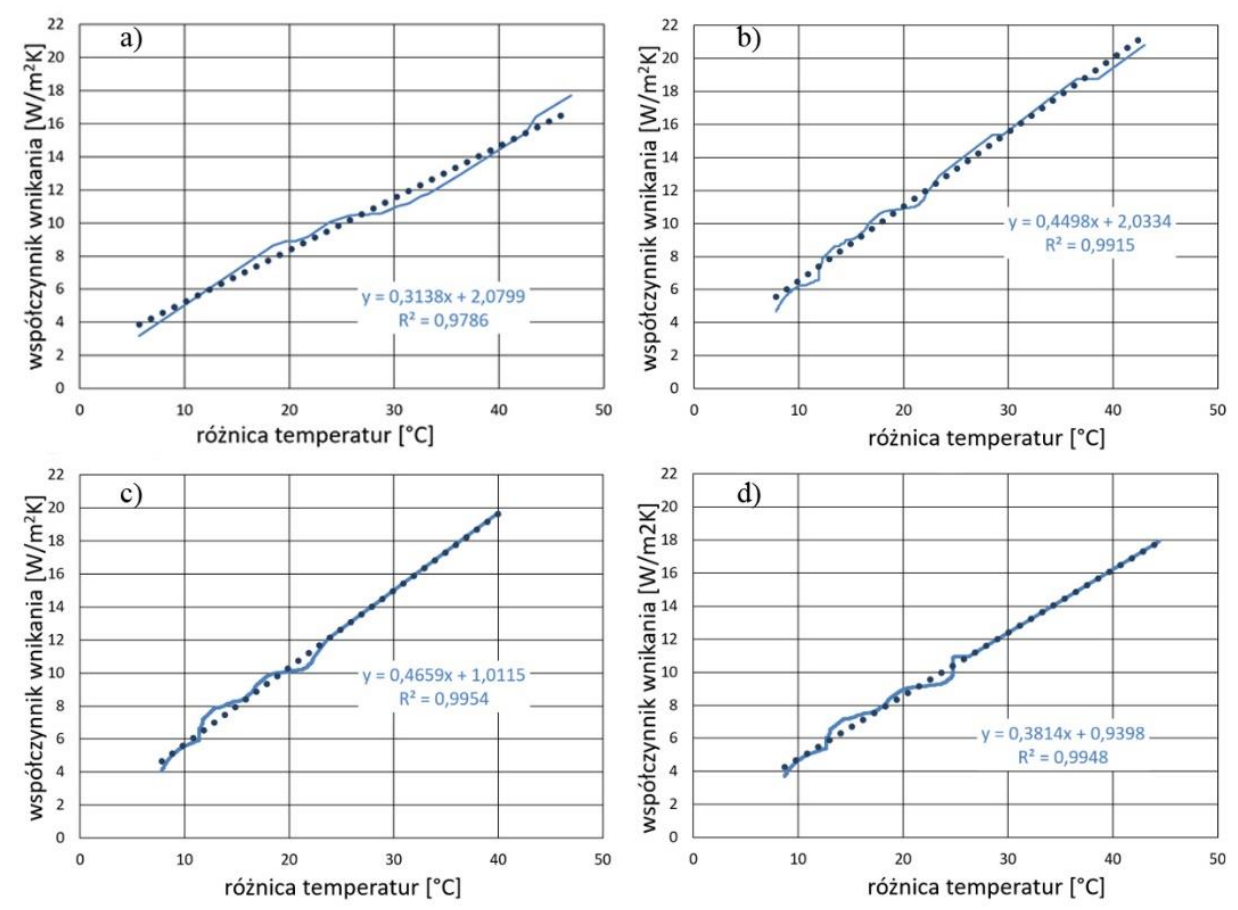

Rys. 4. Wartość współczynnika wnikania ciepła w zależności od różnicy temperatury pomiędzy powierzchnią a środowiskiem podczas schładzania: a) płyty miedzianej, b) plastrów marchwi, c) plastrów buraka czerwonego, d) bloku sera żółtego

W celu sprawdzenia poprawności uzyskanych wyników pomiarów dokonano porównania ich zestawienia z wartościami współczynnika podawanymi przez literaturę dla rozpatrywanych warunków konwekcji swobodnej. Odczytany z opracowanych wykresów współczynnik wnikania ciepła $\alpha$ dla różnicy temperatur wynoszą- 
cej $20^{\circ} \mathrm{C}$ wynosił odpowiednio: płytka miedziana $8,9 \mathrm{~W} / \mathrm{m}^{2} \mathrm{~K}$, plastry marchwi $11,2 \mathrm{~W} / \mathrm{m}^{2} \mathrm{~K}$, plastry buraka ćwikłowego $10,1 \mathrm{~W} / \mathrm{m}^{2} \mathrm{~K}$ oraz blok sera żółtego $9 \mathrm{~W} / \mathrm{m}^{2} \mathrm{~K}$.

Uzyskane podczas pomiaru wymienniki nie odbiegają od wielkości wymienianej w literaturze tematycznej, gdzie dla powietrza w tych warunkach współczynnik wnikania ciepła $\alpha$ przyjmuje wartość $7 \mathrm{~W} / \mathrm{m}^{2}$.

\section{Wnioski}

Uzyskane podczas badań i pomiarów wyniki umożliwiły sformułowanie następujących wniosków:

1. Współczynnik wnikania jest parametrem zmiennym w trakcie zachodzących procesów schładzania i zamrażania. Jego wartość jest kształtowana przez gradient temperatury pomiędzy powierzchnią wymiany a średnią temperaturą środowiska schładzającego.

2. Zmiana wartości współczynnika wnikania ciepła podczas procesów schładzania ma charakter liniowy, co potwierdzone jest wysokimi współczynnikami korelacji dla proponowanych linii trendu.

3. Współczynnik wnikania ciepła nie jest parametrem zależnym od właściwości cieplnych materii, której powierzchnia wymienia ciepło z otaczającym płynem, ale jest wielkością ściśle uwarunkowaną przez właściwości płynu, $\mathrm{z}$ którym następuje wymiana ciepła.

\section{Bibliografia}

Atkins P.W., 2001. Chemia fizyczna. Wyd. Nauk. PWN, Warszawa, 124.

BIPM - Bureau International des Poids et Mesures. The International System of Units (SI), 9th ed. 2019. BIPM, France, 127-198.

Hamadi M.M., Mohsein Z.H., 2017. Variation of heat transfer coefficient for inside and outside closed space with respect to temperature gradient for three different metals. Eng. Tech. J. 35(5), 537-545.

Kassai M., Simonson C.J., 2015. Preformance investigation of liquid-to-air membrane Energy exchanger under low solution/air heat capacity rates ratio conditions. Build. Serv. Eng. Res. Tech. 36(5), 535-545, https://doi.org/10.1177/0143624414564445

Kmieć A., 2005. Procesy cieplne i aparaty. Wrocław, 9-27.

Kostkowski E., 1986. Przepływ ciepła. Wyd. Pol. Śl., Gliwice.

Lienhard IV J.H., Lienhard V J.H., 2019. A heat transfer textbook, 5th ed., Cambridge.

Michalski L., Eckerdorf K., 1969. Pomiary temperatury. WNT, Warszawa.

Nadziakiewicz J., 1998. Laboratorium techniki cieplnej. Wyd. Pol. Śl., Gliwice.

Pudlik W., 2012. Wymiana i wymienniki ciepła. Podręcznik dla studentów wydziałów mechanicznych specjalizujących się w technikach cieplnych i chłodniczych. Politechnika Gdańska, Gdańsk, 7-25.

Sheikholeslami M., Gorji-Bandpy M., Ganji D.D., 2015. Review of heat transfer enthancement: focus on passive methods using swirl flow devices. Renew. Sustain. Energy Rev., 49, 444-469, https://doi.org/10.1016/j.rser.2015.04.113 
Sheikholeslami M., Vajravelub K., Rashidicd M.M., 2016. Forced convection heat transfer in a semi annulus under the influence of a variable magnetic field. International J. Heat Mass Transfer 92, 339-348, https://doi.org/10.1016/j.ijheatmasstransfer.2015.08.066

Staniszewski B., 1986. Termodynamika. PWN, Warszawa.

Wiśniewski S., Wiśniewski T.S., 1979. Wymiana ciepła. PWN, Warszawa.

Zhou M., Alexandersen J., Sigmund O., Pedersen C.B., 2016. Industrial application of topology optimization for combined conductive and convective heat transfer problems. Struct. Multidisc. Optim. 54, 1045-1060, https://doi.org/10.1007/s00158-016-1433-2 
Dominika Pruś ${ }^{1}$, Monika Stoma $\mathbb{D}^{2}$, Agnieszka Dudziak $\mathbb{D}^{3}$

\title{
Ocena świadomości wpływu sztucznej inteligencji na życie konsumentów
}

\author{
Assessment of awareness of artificial intelligence impact on the life of consumers
}

\begin{abstract}
Wstęp
Temat sztucznej inteligencji jest obecnie rozpatrywany w wielu aspektach zarówno od strony teoretycznej, jak i praktycznej. Dzieje się tak, bowiem różne podmioty rynku, nie tylko zaawansowane technologicznie przedsiębiorstwa produkcyjne, usługowe, ale też z branży rolno-spożywczej, a także indywidualni konsumenci, korzystają z jej osiągnięć już na co dzień, np. podczas obsługi telefonu komórkowego czy różnego rodzaju aplikacji, niejednokrotnie nie zdając sobie sprawy z faktu, jakiego narzędzia czy algorytmu używają. Dlatego też po analizie dostępnej literatury dotyczącej istoty oraz możliwości wykorzystania sztucznej inteligencji, a także obserwacji różnych jednostek społeczeństwa, pojawiło się następujące pytanie badawcze: czy konsumenci zdają sobie sprawę z tego, że w codziennym życiu wykorzystują elementy sztucznej inteligencji i jaki ma ona wpływ na ich życie.

Celem pracy jest zbadanie i analiza postaw współczesnych konsumentów wobec problematyki sztucznej inteligencji oraz możliwości i świadomości jej wykorzystywania w codziennym życiu. Tak postawiony cel pracy został zrealizowany poprzez przeprowadzenie badań ankietowych z wykorzystaniem autorskiego kwestionariusza wśród respondentów z woj. lubelskiego.
\end{abstract}

\section{Istota sztucznej inteligencji}

Rozpoczynając analizę świadomości wpływu rozwiązań z zakresu sztucznej inteligencji na codziennie życie konsumentów, należy najpierw zdać sobie sprawę z tego, co to jest sztuczna inteligencja (w skrócie SI) i jakie obszary obejmu-

\footnotetext{
${ }^{1}$ Studenckie Koło Naukowe Zarządzania i Ekonomii, Uniwersytet Przyrodniczy w Lublinie, dominikama197@onet.pl

${ }^{2}$ Katedra Energetyki i Środków Transportu, Zakład Logistyki i Zarządzania Przedsiębiorstwem, Wydział Inżynierii Produkcji, Uniwersytet Przyrodniczy w Lublinie, monika.stoma@up.lublin.pl

${ }^{3}$ Katedra Energetyki i Środków Transportu, Zakład Logistyki i Zarządzania Przedsiębiorstwem, Wydział Inżynierii Produkcji, Uniwersytet Przyrodniczy w Lublinie, agnieszka dudziak@up.lublin.pl
} 
je. Według jednej z definicji jest to nauka o tym, jak produkować maszyny wyposażone w niektóre cechy ludzkiego umysłu, takie jak umiejętność rozumienia języka, rozpoznawania obrazów, rozwiązywania problemów i uczenia się [www.sztucznainteligencja.org.pl]. Badania nad sztuczną inteligencją wykorzystują narzędzia i ustalenia $\mathrm{z}$ wielu dziedzin, m.in. informatyki, psychologii, filozofii, kognitywistyki, lingwistyki, badań operacyjnych, ekonomii, teorii sterowania, prawdopodobieństwa, optymalizacji i logiki. Sam termin wprowadził John McCarthy, amerykański informatyk, na konferencji naukowej w Dartmouth w 1955 r. [Warszycki 2019].

Inna definicja mówi, że sztuczna inteligencja jest nauką o czynnościach, które miałyby spowodować, że maszyny będą wykonywać funkcje, które aktualnie lepiej wykonuje człowiek [Różanowski 2007].

Zadaniem sztucznej inteligencji jest badanie reguł rządzących inteligentnymi zachowaniami człowieka i wykorzystanie ich w algorytmach i programach komputerowych. Przykładem takich rozwiązań są programy do rozpoznawania tekstów, obrazów, dźwięków, translatory, uczenie maszyn itd. [https://encyklopedia.pwn.pl].

\section{Najnowsze rozwiązania SI}

Oprócz szeroko pojętego rozwoju elektronicznego, gdzie sztuczną inteligencję wykorzystuje się, np. w blokadach telefonów komórkowych czy w postaci wyszukiwarki internetowej, inne dziedziny również wykorzystują rozwiązania $\mathrm{z}$ tego zakresu. Jedną z nich jest niewątpliwie medycyna. W ostatnim czasie powstał pierwszy antybiotyk, który został odkryty dzięki wykorzystaniu tzw. uczenia maszynowego, jednej z umiejętności SI [https://noizz.pl/nauka-i-technologia]. W tym przypadku sztuczna inteligencja wyszła naprzeciw rosnącej antybiotykooporności bakterii.

Kolejnym nowym przykładem zastosowania SI jest wyszkolenie jednego z modeli sztucznej inteligencji do wykrywania raka piersi, by zmniejszyć odsetek złych diagnoz. Okazało się, że w porównaniu ze specjalistami algorytmy sztucznej inteligencji osiągnęły lepsze wyniki w wykrywaniu raka piersi przy użyciu techniki głębokiego uczenia oraz szkolenia na obrazach z badań mammograficznych wykonanych u 76 tys. kobiet [https://dzienniknaukowy.pl].

Innym nowym obszarem zastosowania sztucznej inteligencji jest rolnictwo. W tym roku powstał nowy algorytm do dokładniejszego przewidywania poziomu plonów. Również do jego powstania wykorzystano głębokie uczenie maszynowe, co pozwoliło na wyjaśnianie zróżnicowania w poziomie plonów na danym obszarze [www.farmer.pl].

Przedstawiono tutaj tylko kilka przykładów wykorzystania SI w całkowicie nowych obszarach działalności człowieka. $Z$ czasem będzie pojawiało się jeszcze więcej nowych rozwiązań w dziedzinach, które do tej pory nie były nawet przekonane do zastosowania sztucznej inteligencji. 


\section{Metoda badań}

Aby określić postawy konsumentów wobec problematyki SI, a także by zrealizować postawiony cel pracy zostało przeprowadzone badanie za pomocą autorskiej ankiety. Ankieta została przeprowadzona internetowo, w sposób anonimowy wśród 128 respondentów mieszkających na terenie woj. lubelskiego.

Ankieta składała się z 10 pytań jednokrotnego wyboru. Została podzielona na dwie części. Pierwsza z nich - metryczka - zawierała pytania pozwalające na dokonanie charakterystyki społeczno-demograficznej respondentów, biorąc pod uwagę takie zmienne, jak: płeć, wiek, miejsce zamieszkania oraz wykształcenie. Druga cześć ankiety składała się z pytań pozwalających ocenić wiedzę ankietowanych na temat sztucznej inteligencji oraz ich postawy wobec wybranych aspektów oddziaływania rozwiązań z zakresu SI na ich codzienne życie, biorąc szczególnie pod uwagę możliwości, korzyści, a także zagrożenia wynikające ze stosowania na szeroką skalę rozwiązań $\mathrm{z}$ analizowanego obszaru.

\section{Wyniki badań i dyskusja}

W celu przedstawienia ocen respondentów uzyskane wyniki zostały zaprezentowane zarówno w formie graficznej, tabelarycznej, jak i opisowej.

Pytania zawarte $\mathrm{w}$ metryczkowej części ankiety umożliwiły scharakteryzowanie respondentów pod względem płci, wieku, wykształcenia oraz miejsca zamieszkania. Charakterystykę demograficzno-społeczną badanych przedstawiono w tabeli 1.

W dalszej części pracy skupiono się na analizie merytorycznej części ankiety. Odpowiedzi udzielone przez badanych zostały zobrazowane na wykresach $1-3$, a następnie dokonano ich interpretacji.

$\mathrm{Na}$ początku zestawiono informacje pozwalające na przedstawienie i ocenę poziomu wiedzy na temat istoty sztucznej inteligencji wśród badanych respondentów. Jak wynika $\mathrm{z}$ ankiety, ponad $70 \%$ badanych jest zaznajomiona $\mathrm{z}$ tematem sztucznej inteligencji. Tylko 3,2\% zadeklarowało, że nie wie, co to jest SI. Resztę stanowią osoby, które zdecydowanie uważają, że znają pojęcie SI, ale także interesują się tym tematem. Takie wyniki badań mogą świadczyć mimo wszystko o powierzchownej wiedzy na temat sztucznej inteligencji.

Ponad $40 \%$ ankietowanych zadeklarowało, że interesuje się tematem SI, ale bardzo rzadko. Ta odpowiedź została bowiem najwięcej razy wskazana przez respondentów w pytaniu dotyczącym śledzenia nowinek ze świata sztucznej inteligencji. Odpowiedź, że ankietowani śledzą nowinki od czasu do czasu wskazało 38\% ankietowanych. Spośród badanych 12,4\% osób w ogóle nie interesuje się tematem SI. Może to świadczyć o zbyt małej liczbie ogólnodostępnych wiadomości na temat nowości z tej dziedziny. 
Tabela 1. Charakterystyka demograficzno-społeczna badanej populacji

\begin{tabular}{|l|c|c|}
\hline \multicolumn{1}{|c|}{ Zmienne } & $\begin{array}{c}\text { Liczba } \\
\text { respondentów }\end{array}$ & $\begin{array}{c}\text { Udział } \\
\text { procentowy }\end{array}$ \\
\hline Ogółem & 127 & 100 \\
\hline Płeć: & 32 & 25,2 \\
mężczyzna & 95 & 74,8 \\
kobieta & & \\
\hline Wiek: & 8 & 6,3 \\
0-18 lat & 62 & 48,8 \\
19-25 lat & 27 & 21,3 \\
26-40 lat & 25 & 19,7 \\
41-60 lat & 5 & 3,9 \\
powyżej 60 lat & & \\
\hline Wykształcenie: & 9 & 7,1 \\
podstawowe & 3 & 2,4 \\
zawodowe & 51 & 40,2 \\
średnie & 64 & 50,4 \\
wyższe & 39 & 30,7 \\
\hline Miejsce zamieszkania: & 13 & 10,2 \\
wieś & 18 & 14,2 \\
miasto do 30 tys. mieszkańców & 57 & 44,9 \\
miasto od 30 do 300 tys. mieszkańców & & \\
miasto powyżej 300 tys. mieszkańców & & \\
\hline
\end{tabular}

Na podobnym poziomie ukształtowały się odpowiedzi respondentów odnośnie do kwestii częstotliwości korzystania przez nich z możliwości, jakie daje im sztuczna inteligencja; okazało się bowiem, że 32,2\% bardzo często z nich korzysta, a 29,8\% - czasami. Łącznie ponad 3/4 ankietowanych uważa, że SI ma bardzo duży lub duży wpływ na nasze codzienne życie.

Ankietowani najczęściej korzystają z wyszukiwarki internetowej jako elementu, w którym zastosowano sztuczną inteligencję, bo aż w 93,7\% przypadków. Kolejną opcją, z której korzystają bardzo często, są rekomendacje aplikacji typu Netflix, Spotify czy YouTube (80,2\%). Wskazuje to na częste korzystanie respondentów z Internetu oraz telefonu komórkowego, co w obecnych czasach jest bardzo powszechną czynnością. Tylko 4,8\% osób biorących udział w ankiecie korzysta $\mathrm{z}$ samochodów autonomicznych. Jest to zapewne spowodowane tym, że nie każdy może sobie pozwolić na posiadanie i utrzymanie pojazdu autonomicznego, co wiąże się z wysokimi kosztami.

Odpowiadając na pytanie dotyczące korzyści ze stosowania sztucznej inteligencji, respondenci, dokonując wyboru spośród podanych odpowiedzi, mogli oddać maks. 3 głosy. Jak wynika z uzyskanych wyników, ankietowani najczęściej wskazywali na poprawę komfortu życia - 73,2\%. Bardziej efektywne wykorzystanie czasu to druga $\mathrm{w}$ kolejności najczęściej wybierana odpowiedź zebrała ona bowiem $48 \%$ głosów. Na podobnym poziomie, bo ok. $40 \%$, ukształtowały się kolejne zadeklarowane przez badanych korzyści, tj. większa samodzielność niektórych grup społecznych (np. osób niepełnosprawnych, osób starszych) oraz bardziej efektywne przetwarzanie informacji i bardziej precyzyjna 
analiza danych. Tylko 15,7\% uzyskała odpowiedź, że SI pozwoli na podejmowanie lepiej umotywowanych decyzji, np. zakupowych.

Aż 76\% osób biorących udział w badaniu wskazało zbytnie uzależnienie od technologii jako największe zagrożenie związane ze stosowaniem sztucznej inteligencji na szeroką skalę. Kolejnym zagrożeniem według ankietowanych jest możliwość cyberprzestępstw - 65,6\%. Następnie 57,6\% wyraziło swoją opinię, że SI może mieć negatywne konsekwencje dla rynku pracy. Panuje niestety stereotyp, że sztuczna inteligencja zabiera ludziom miejsca pracy. W badaniu KRC Research dla Weber Shandwick aż 82\% konsumentów również spodziewa się redukcji miejsc pracy [https://nasluchawkach.pl/]. By usprawnić naszą pracę i podwyższyć jej efektywność, możemy przekazać sztucznej inteligencji pewne czynności do zrobienia, ale należy pamiętać, iż pracy ludzkiej nie da się po prostu do końca wyeliminować [www.pulshr.pl].

Respondentów poproszono również o ustosunkowanie się do pytania, w jakich dziedzinach SI może mieć szerokie zastosowanie. Uzyskane odpowiedzi przedstawiono na wykresie (rys. 1).
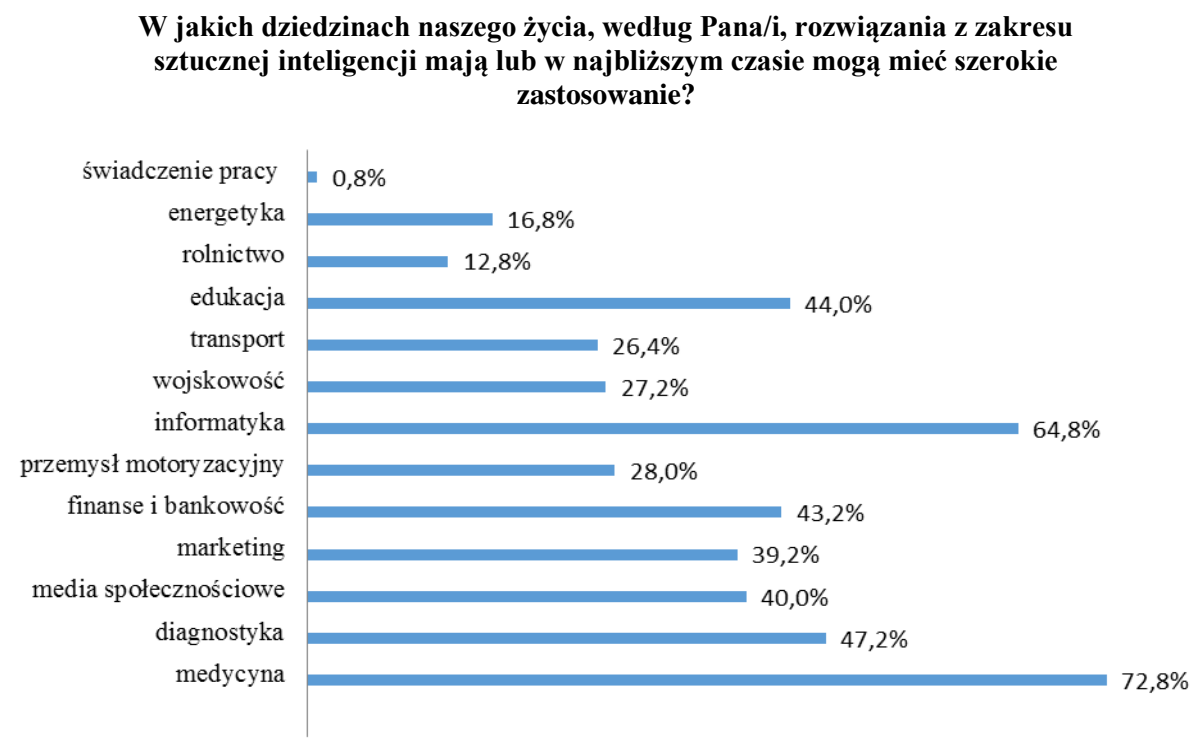

Rys. 1. Zastosowanie sztucznej inteligencji w różnych dziedzinach. Źródło: badanie własne

Odpowiadając na pytanie, w jakich dziedzinach naszego życia rozwiązania z zakresu SI mają lub będą miały w najbliższym czasie szerokie zastosowanie, ankietowani wybrali medycynę $(72,8 \%)$. Drugą dziedziną, którą wskazali $(64,8 \%)$, była informatyka. Mimo że ankietowani tak wysoko ocenili medycynę, to jednak niewielu $(15,6 \%)$ słyszało o nowym antybiotyku odkrytym właśnie przez SI, który będzie stosowany w nieuleczalnych dotąd infekcjach, co widać na wykresie przedstawiającym rozwiązania z zakresu SI (rys. 2). 


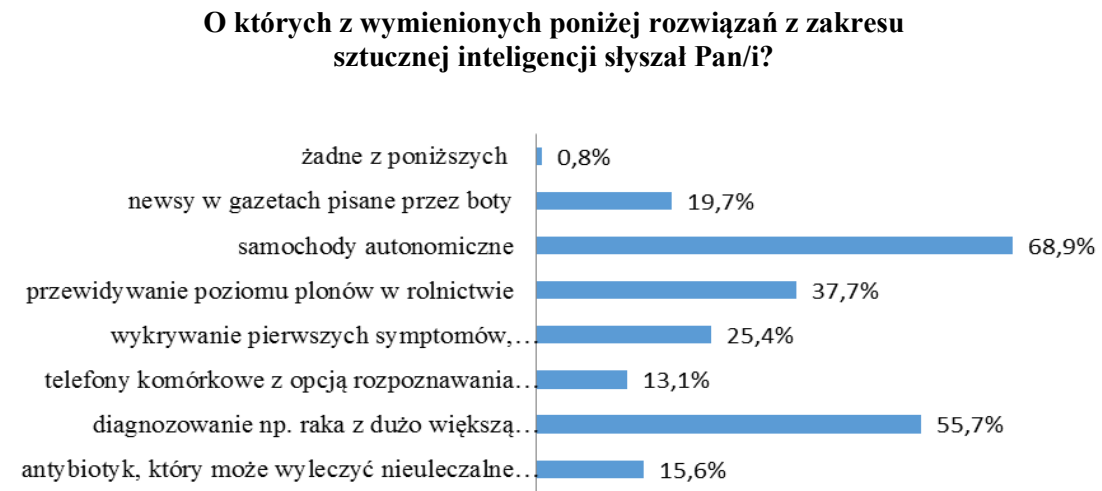

Rys. 2. Rozwiązania z zakresu sztucznej inteligencji. Źródło: badanie własne

Jak wynika $z$ danych zaprezentowanych na rysunku 2, samochody autonomiczne to przykład rozwiązania z zastosowaniem elementów SI, o którym ankietowani słyszeli najczęściej (taką odpowiedź wskazało bowiem prawie $70 \%$ badanych). Ponad połowa respondentów - jako drugie rozwiązanie, o którym słyszeli - wskazała również diagnozowanie raka przez SI z dużo większą dokładnością niż przez lekarzy. Mogłoby to wskazywać na dość duże zainteresowanie wśród ankietowanych motoryzacją oraz medycyną.

Ankietowanych poproszono również o wskazanie czynności, które powierzyliby sztucznej inteligencji (rys. 3).

Jakie czynności powierzyłby Pan/i sztucznej inteligencji?

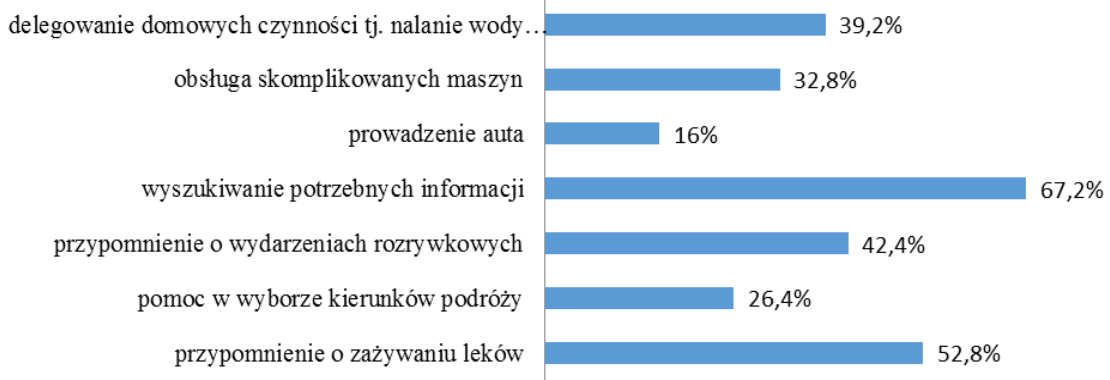

Rys. 3. Czynności powierzane sztucznej inteligencji. Źródło: badanie własne

Informacje zestawione na wykresie (rys. 3) pozwalają na stwierdzenie, że czynnością, jaką ankietowani powierzyliby sztucznej inteligencji, jest przede wszystkim wyszukiwanie potrzebnych informacji - taką odpowiedź zadeklarowało bowiem aż $67,2 \%$ respondentów. Drugą w kolejności odpowiedzią było przypominanie o zażywaniu leków - wskazała ją ponad połowa ankietowanych. Mogłoby to świadczyć o tym, że respondenci mają problem z regularnym zażywaniem leków. Uzyskane wyniki potwierdzają również wyniki badań przeprowadzonych przez KRC na 
pięciu rynkach, z których wynika, że dwie trzecie badanych chciałaby, aby SI przypominała im o zażywaniu leków [https://nasluchawkach.pl].

Najmniej ankietowanych (16\%) powierzyłaby sztucznej inteligencji prowadzenie auta, mimo że w poprzednim pytaniu $68,9 \%$ respondentów oddało swój głos na samochody autonomiczne. Może to wskazywać na dość słabą znajomość zagadnień dotyczących pojazdów autonomicznych wśród osób biorących udział w ankiecie, gdyż już pierwsze jazdy próbne pokazały, że kiedy samochodem kieruje maszyna, wypadki zdarzają się zdecydowanie rzadziej. Jest to spowodowane tym, że tego rodzaju pojazdy, wyposażone w różne czujniki, radary i kamery, są w stanie wykrywać sytuację na drodze i reagować na uczestników ruchu [www.sunrisesystem.pl]. Dlatego też na podstawie tych testów uznano czynnik ludzki jako najniebezpieczniejszy element samochodowej układanki - nieprzewidywalny, podlegający zmęczeniu i niezbyt precyzyjny [www.spidersweb.pl].

\section{Wnioski}

Jednym z wielu wniosków, jakie można sformułować po przeprowadzeniu badań, jest to, że poziom wiedzy zarówno na temat sztucznej inteligencji, jak i rozwiązań w tym obszarze, a także poziom świadomości wpływu SI na życie człowieka, waha się u osób w różnych przedziałach wiekowych. Prawie połowa osób biorących udział w badaniu to osoby od 19. do 25 . roku życia. To właśnie ta kategoria wiekowa jest najbardziej zainteresowana tematem sztucznej inteligencji. $\mathrm{O}$ połowę mniejszym zainteresowaniem SI cieszy się wśród osób w przedziale wiekowym 26-40 lat oraz 41-60 lat.

Kolejnym wnioskiem jest to, że respondenci niechętnie powierzyliby sztucznej inteligencji prowadzenie auta, ale zdecydowana większość miała styczność z informacjami w tym zakresie. Respondenci uważają ponadto, że medycyna będzie tą dziedziną, która może najbardziej skorzystać z osiągnięć SI, ale wielu $\mathrm{z}$ nich nie słyszało o najnowszych udogodnieniach w tym obszarze.

Ostatnim ważnym wnioskiem jest fakt, że ankietowani niejednokrotnie korzystają z osiągnięć sztucznej inteligencji, ale nie zawsze mają świadomość, że dana rzecz jest efektem działania algorytmów SI.

\section{Bibliografia}

https://dzienniknaukowy.pl/nowe-technologie/sztuczna-inteligencja-lepsza-w-wykrywaniu-rakapiersi-od-lekarzy [data dostępu: 26.03.2020].

http://encyklopedia.pwn.pl/30489_1.html [data dostępu: 27.03.2020].

https://nasluchawkach.pl/badania-i-raporty/sztuczna-inteligencja-jestesmy-nia-gotowi-badanie-

krc-research/ [data dostępu: 26.03.2020]. 
https:/noizz.pl/nauka-i-technologia/sztuczna-inteligencja-znalazla-nowy-antybiotyk-na-nieuleczalneinfekcje/lmm5193?utm_source=noizz.pl_viasg_noizz\&utm medium=referal\&utm campaign=leo_automatic\&srcc=ucs\&utm_v=2 [data dostępu: 26.03 .2020$]$.

https://www.farmer.pl/produkcja-roslinna/zboza/sztuczna-inteligencja-dokladniej-przewidziplony-kukurydzy,92269.html [data dostępu: 26.03.2020].

https://www.pulshr.pl/zarzadzanie/sztuczna-inteligencja-zabiera-prace-ludziom-to-krzywdzacystereotyp,67747.html [data dostępu: 26.03.2020].

https://www.spidersweb.pl/2017/05/intel-sztuczna-inteligencja.html [data dostępu: 26.03.2020]. https://www.sunrisesystem.pl/blog/2153-sztuczna-inteligencja-w-naszym-codziennym-zyciu-.html [data dostępu: 26.03.2020].

https://www.sztucznainteligencja.org.pl/definicja/sztuczna-inteligencja/ [data dostępu: 25.03.2020].

Różanowski K., 2007. Sztuczna inteligencja rozwój, szanse i zagrożenia. Zesz. Nauk. WWSI 2, $109-135$.

Warszycki M., 2019. Wykorzystanie sztucznej inteligencji do predykcji emocji konsumentów. Stud. Pr. Kol. Zarz. Finans. (Szk. Gł. Handl.). Zesz. Nauk. 173, 111-121. 
Anna Rodzeń(1) ${ }^{1}$, Monika Stoma $\mathbb{B}^{2}$

\title{
Zastosowanie metody SERVQUAL do oceny jakości usług transportowych
}

\author{
Application of the SERVQUAL method for assessing the quality of transport services
}

\begin{abstract}
Wstęp
Sektor rolno-spożywczy stanowi jedną z najważniejszych branż gospodarek całego świata. Na przestrzeni ostatnich 20 lat w naszym kraju nastąpiło wiele zmian w tym sektorze z uwagi na chociażby wstąpienie Polski do Unii Europejskiej. Nieustanny postęp technologiczny i techniczny ustanawia go priorytetową sferą polskiej gospodarki. Znaczenie sektora rolno-spożywczego jest niezmiernie duże, bowiem zapewnia on m.in. odpowiedni poziom wyżywienia społeczeństwa, spełniając kluczową rolę w systemie gospodarczym kraju. Biorąc pod uwagę obecną sytuację w branży rolno-spożywczej, warto skupić się na jakości usług transportowych, które w dużym stopniu decydują o funkcjonowaniu analizowanego sektora [Kiełbasa 2015].

Należy podkreślić, że transport jako działalność usługowa jest jednym z najważniejszych determinant rozwoju społeczno-gospodarczego, w tym w sektorze rolno-spożywczym. Stworzenie modelu jakości usług transportowych w ocenie przedsiębiorstw z branży rolno-spożywczej może stać się podstawą do poprawy i doskonalenia poziomu jakości tych usług. Proces ten, jak się wydaje, jest nieodzownym elementem sprawnego i efektywnie funkcjonującego każdego działu gospodarki narodowej, ze szczególnym uwzględnieniem sektora rolno-spożywczego.

Nieodłącznym elementem każdej działalności jest pojęcie jakości usług, ponieważ przekłada się na stopień zadowolenia i lojalności klientów firm usługowych. Ma to odzwierciedlenie w aspekcie finansowym danej firmy świadczącej usługi. Należy podkreślić, że nadrzędnym działaniem każdego przedsiębiorstwa usługowego powinna być kompleksowa obsługa klienta, nie zaś działania marketingowe. Niestety w większości przypadków, jak się wydaje, spotykamy się z firmami zorientowanymi na zysk, a jakość usług postrzegana i oceniana jest przez wewnętrzny schemat przedsiębiorstwa. Jednakże jakość i obsługa klienta

\footnotetext{
${ }^{1}$ Katedra Energetyki i Środków Transportu, Wydział Inżynierii Produkcji, Uniwersytet Przyrodniczy w Lublinie, annarodzen93@gmail.com

${ }^{2}$ Katedra Energetyki i Środków Transportu, Wydział Inżynierii Produkcji, Uniwersytet Przyrodniczy w Lublinie, monika.stoma@up.lublin.pl
} 
są integralną częścią jego istnienia na rynku i pozycjonują firmę w branży, umożliwiając tym samym stworzenie efektywnej polityki konkurencyjnej.

W dostępnej literaturze przedmiotu brak jest kompleksowej metodologii badawczej w obszarze jakości usług, a także modelu charakterystyki wymiarowej usług transportowych w opinii przedsiębiorstw sektora rolno-spożywczego. Stąd też celem pracy jest podjęcie próby takiej kompleksowej analizy problemu, gdzie pierwszym krokiem jest wyznaczenie charakterystyki wymiarowej usług transportowych.

\section{Założenia metody SERVQUAL w aspekcie usług transportowych}

W krajach wysoko rozwiniętych transport samochodowy stanowi najważniejszą rolę w obrocie towarowym, bowiem jest najlepszym i najszybszym środkiem do przewożenia wszelkiego rodzaju towarów. Sytuacja ta wymaga jednak znajomości systemu logistycznego wraz ze sprzężeniami zwrotnymi, które stanowią procesy towarzyszące.

Współcześnie funkcjonujące przedsiębiorstwa, działające zarówno na rynku krajowym, jak i międzynarodowym, muszą prowadzić efektywną logistykę. Wykorzystują do tego celu dostępne narzędzia, jednakże postęp technologiczny skłania je do nieustannego poszukiwania jeszcze lepszych środków doskonalących te procesy, aby wytworzyć wartość dodaną dla klienta, jak również zachować odpowiedni poziom ekonomiczności tego przedsięwzięcia. Ponadto przedsiębiorstwa posiadające efektywne systemy logistyczne opracowują model standardów obsługi klienta, dotyczący m.in. cyklu realizacji zamówienia, kompletności dostaw, czasu dostaw czy zgodności warunków realizacji usługi z umową. Dzieje się to za sprawą właściwej identyfikacji oczekiwań potencjalnych i stałych klientów, a także prawidłowej interpretacji odchyleń, gdzie np. nadmierna liczba uszkodzonych towarów może być sygnałem do poprawy jakości pracy transportu czy zastosowania opakowań ochronnych [Szymanowski 2008]. Należy podkreślić, że nawet systematyczna weryfikacja poziomu obsługi klienta i jego jego satysfakcji nie jest w stanie dostarczyć informacji na tyle szybko, aby w odpowiednim czasie zareagować na problem [Stajniak 2012]. Dlatego też istotnym czynnikiem staje się proces kontroli, w trakcie którego należy rejestrować odchylenia od wspomnianych standardów.

Reasumując, standardy to gwarancja jakości oferowana przez usługodawców w obszarze obsługi klienta. Aby dokonać ich określenia, punktem wyjścia staje się analiza potrzeb i oczekiwań klientów. Stawia to przed rynkiem usług trudne zadanie $\mathrm{z}$ uwagi na ich niematerialny charakter. Skoncentrowanie uwagi przy określaniu jakości usług na kliencie i stopniu jego zadowolenia odgrywa kluczową rolę. Dlatego proces ten jest powszechnie definiowany jako stopień spełniania oczekiwań nabywców. Usługa o odpowiedniej jakości to taka, której stopień realizacji spełnia lub przekracza oczekiwania konsumenta [Czubała i in. 2006]. 
Metoda SERVQUAL to jedna z technik oceny i zarządzania jakością usług. Koncepcja została opracowana i zaproponowana przez Parasuramana, Zeithamla i Berry'ego, którzy przez kolejnych 8 lat ją rozwijali. Wielu innych badaczy wykorzystało wymiary SERVQUAL jako podstawę swoich badań, gdzie podejmowano próby stworzenia uniwersalnego modelu wymiarowego opisu usługi [Doroszewicz i Stoma 2007]. Jednakże ich konsekwentna analiza pozwoliła wysunąć wniosek, że sposób postrzegania, który przekłada się na ocenę, jest w ścisłej korelacji z rodzajem ocenianego obiektu, schematem poznawczym i czynnikami sytuacyjnymi [Asubonteng $\mathrm{i}$ in. 1996]. Ponadto w przypadku rozpatrywanej usługi transportowej dostosowanie uniwersalnie wykorzystywanego kwestionariusza SERVQUAL, jak się wydaje, jest błędem.

Szerokie zastosowanie wspomnianej metody w badaniu postrzegania jakości wielu rodzajów usług i obszarów działalności firm usługowych przyczyniło się do jej krytyki. Jedną z podnoszonych niedoskonałości jest m.in. brak jej uniwersalności czy jednoznaczności niektórych stwierdzeń, a tym samym możliwość ich odmiennego rozumienia przez respondentów oraz wysoka korelacja pomiędzy niektórymi kryteriami. Przy ocenie jakości usług nie jest wskazane, aby uwzględniać różnicę między ocenami spostrzeżeń i oczekiwań, jak to proponują twórcy koncepcji SERVQUAL, którzy zdefiniowali 5 luk jakości usług odnoszących się do niezadowolenia klienta - co przejawia się niską oceną jakości [Karaszewski 2001]. Analizując proces szeroko rozumianej satysfakcji klienta i oceny jakości świadczonych usług, kluczowym elementem metody SERVQUAL jest piąta luka, gdzie dokonuje się oceny rzeczywistego odbioru usługi przez klienta. Cronin i Taylor stwierdzili, że zestawienie jakości doświadczonej do jakości oczekiwanej, co obrazują pozostałe 4 luki z wykorzystaniem podobnych kwestionariuszy, jest działaniem nieodpowiednim. Zaproponowana przez nich metoda SERVPERF skupia się jedynie na jakości doświadczonej, która zestawiana jest z jakością oczekiwaną (jakością idealną). Uważali bowiem, że nie ma konieczności badania oczekiwań klientów, ponieważ zawsze będą spodziewać się jakości na możliwie najwyższym poziomie.

Prowadzi to do wysunięcia wniosku, że wbrew autorom metoda ta nie może zostać wykorzystana w zaproponowanej, niezmienionej formie, w pomiarze jakości wszystkich rodzajów usług. Model SERVQUAL nie jest modelem uniwersalnym przedsiębiorstwa sektora rolno-spożywczego, które korzystają z usług transportowych, odmiennie postrzegają tę usługę niż wynika to z 5-wymiarowej koncepcji SERVQUAL. Przejawia się to zarówno w liczbie wymiarów, ich strukturze, jak i ważności poszczególnych wymiarów kryterialnych dla klientów.

\section{Metoda badań}

Procedura badawcza została ukierunkowana na wyznaczenie charakterystyki wymiarowej oraz modelu jakości usług transportowych postrzeganych przez 
przedsiębiorstwa funkcjonujące na rynku rolno-spożywczym, we wszystkich ogniwach łańcucha żywnościowego z obszaru południowo-wschodniej Polski, ze szczególnym uwzględnieniem województwa lubelskiego i podkarpackiego. Zaproponowana procedura badawcza składa się z trzech głównych etapów, czyli projektowania badań, badań pilotażowych i badań zasadniczych. W pracy skoncentrowano się na zaprezentowaniu pierwszego i drugiego etapu.

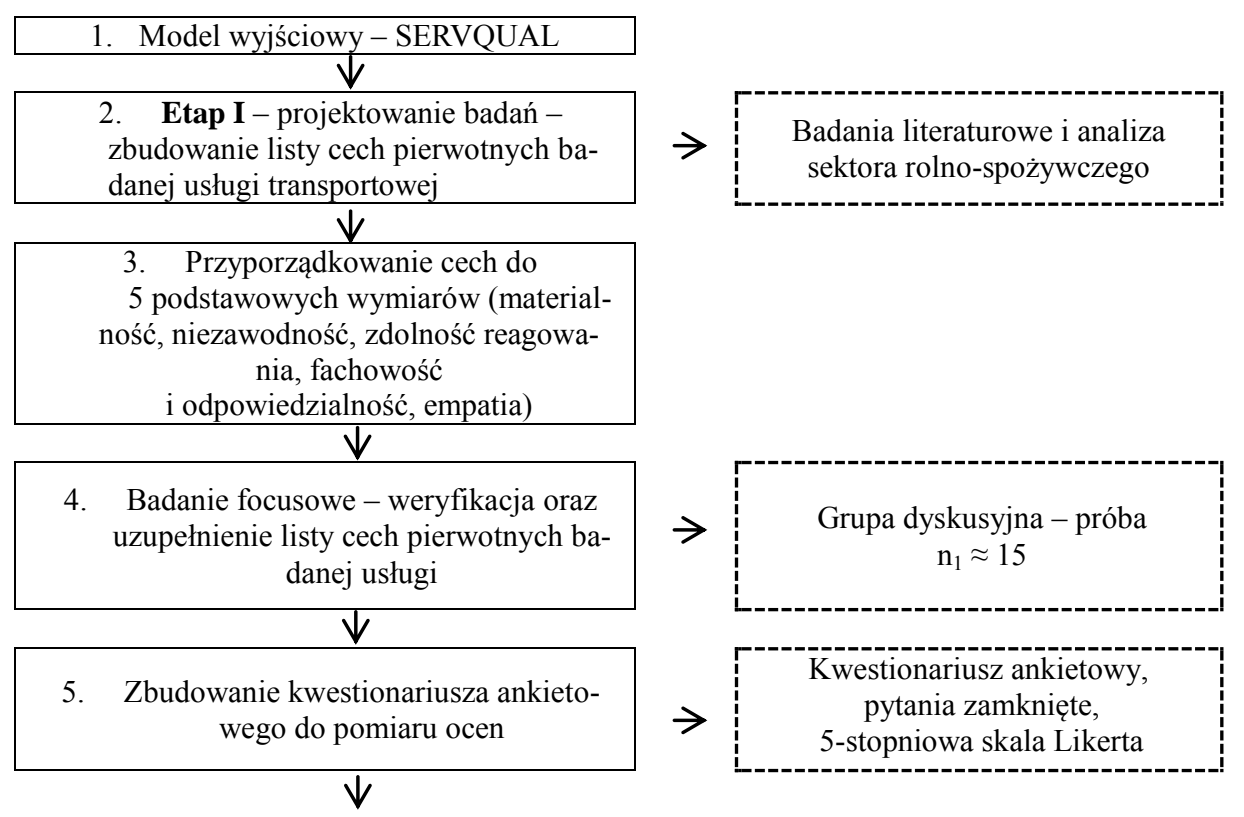

Rys. 1. Schemat budowy kwestionariusza ankietowego

Na podstawie wiedzy teoretycznej - badań literaturowych - zbudowano listę cech pierwotnych badanej usługi transportowej, będącą odpowiedzią na pytanie, jakiego rodzaju właściwości widzi klient (przedsiębiorstwo sektora rolno-spożywczego) w tej usłudze. Oceniając jakość usług transportowych, istotne jest uwzględnienie zdolności jej charakterystyk do zmian, które wynikają ze zmian przepisów prawnych, oczekiwań klientów, czy postępu technologiczno-przemysłowego. Należy podkreślić, że w przypadku usług transportowych jakość będzie inaczej odbierana przez przewoźnika, który musi zmaksymalizować swoje korzyści i pozycję na rynku, a klienta. Musi on bowiem odczuć, że zostały spełnione jego oczekiwania oraz wymagania. Analiza postrzegania tych wartości stanowiła punkt wyjścia całego procesu badawczego. Z kolei poszczególne cechy charakteryzujące usługę transportową zostały przyporządkowywane na liście do pięciu podstawowych zbiorów (wymiarów), a mianowicie:

1) materialności - definiowanej jako wygląd materialnych elementów, które biorą udział przy świadczeniu usługi, 
2) solidności - przejawiającej się w możliwościach usługodawcy do wykonania usługi starannie i dokładnie,

3) empatii - polegającej na troskliwej i zindywidualizowanej obsłudze, jaką usługodawca powinien zapewnić swoim klientom,

4) zdolności reagowania - definiowanej jako chęć pomocy usługobiorcom oraz zapewnienie im szybkiej obsługi,

5) pewności - odzwierciedlonej w wiedzy i uprzejmości pracowników oraz ich umiejętności budzenia zaufania klienta, przy jednoczesnym założeniu, iż struktura każdego z wymiarów może odbiegać od 22-elementowego zbioru pierwotnych cech usługi zaproponowanej przez zespół Parasuramana. W tabeli 1 przedstawiono podstawowe zbiory metody SERVQUAL z uwzględnieniem cech usług transportowych dla tych wymiarów.

Tabela 1. Przykłady charakterystyk wymiarów SERVQUAL dla usługi transportowej

\begin{tabular}{|l|l|}
\hline \multicolumn{1}{|c|}{ Wymiar } & \multicolumn{1}{c|}{ Charakterystyka } \\
\hline Materialność & $\begin{array}{l}\text { poziom technologiczny, wygląd zewnętrzny środków transportu, } \\
\text { atrakcyjność i konkurencyjność elementów oferty, kontrola warun- } \\
\text { ków przewozu za pośrednictwem systemów informatycznych }\end{array}$ \\
\hline Solidność (rzetelność) & $\begin{array}{l}\text { terminowość, kompletność dostaw, dyspozycyjność środków trans- } \\
\text { portu }\end{array}$ \\
\hline Empatia & $\begin{array}{l}\text { ocena dotychczasowej współpracy przedsiębiorstwa transportowego } \\
\text { z klientem, możliwość współpracy na zasadzie outsourcingu, ela- } \\
\text { styczność oferty, kompleksowość usługi }\end{array}$ \\
\hline Zdolność reagowania & $\begin{array}{l}\text { czas trwania wykonania usługi oraz dostępność w czasie, zdolność } \\
\text { reagowania przedsiębiorstwa świadczącego usługe przewozu ładun- } \\
\text { ku na ograniczenia czasowe klientów, sposób sformalizowania trans- } \\
\text { akcji }\end{array}$ \\
\hline $\begin{array}{l}\text { Pewność (fachowość } \\
\text { i zaufanie) }\end{array}$ & $\begin{array}{l}\text { kompetencje załogi, wiarygodność przedsiębiorstwa (czas działania } \\
\text { w branży, rekomendacje klientów), postrzegana jakość usługi (sto- } \\
\text { pień zabezpieczenia przewożonego ładunku) }\end{array}$ \\
\hline
\end{tabular}

Przy wykorzystaniu badań focusowych lista ta została skonfrontowana z przedsiębiorstwami świadczącymi usługi transportowe, aby zweryfikować listę cech pierwotnych, co posłużyło jej wzbogaceniu i rozbudowaniu modelu. Do grupy dyskusyjnej zaproszeni zostali pracownicy i klienci firm transportowych, z którymi przeprowadzone zostały bezpośrednie rozmowy za pomocą wywiadu (rozmowy nieograniczonej czasowo, gdzie uzyskuje się odpowiedzi na zadawane pytania). Respondenci poproszeni zostali o przeanalizowanie wszystkich cech pierwotnych dotyczących usługi transportowej, występującej na otrzymanej liście. Ponadto poproszeni zostali o sformułowanie uwag, spostrzeżeń i własnych sugestii, jak również próbę rozszerzenia listy sformułowanej na podstawie uprzednio wymienionych założeń.

Fazę projektowania badań zakończyło zbudowanie autorskiego narzędzia pomiarowego w postaci kwestionariusza ankietowego na podstawie sformułowanej charakterystyki pierwotnej. Kwestionariusz ten składa się z twierdzeń o pozytywnych 
konotacjach, które odpowiadają poszczególnym cechom listy cech pierwotnych (pytania zamknięte, 5-stopniowa skala Likerta). Proszono respondentów o zaznaczenie jednego z poziomów skali dla każdego z twierdzeń, który najlepiej odzwierciedla ich stosunek do tego twierdzenia. Do ankiety dołączona została metryczka, zawierająca zestawy pytań identyfikujące cechy deskryptywne respondentów (rodzaj przedsiębiorstwa, który reprezentują, jego wielkość, rodzaj prowadzonej działalności, lokalizacja przedsiębiorstwa czy województwo). Dodatkowo ankieta zawierała pytania dotyczące przedsiębiorstwa transportowego, z którego usług korzystają respondenci (wielkość przedsiębiorstwa, zasięg działalności, rodzaj przewożonych produktów, stała umowa z odbiorcami usług, przesłanka wyboru przedsiębiorstwa transportowego, rodzaj środka transportowego, sposób transportowania przewożonych produktów).

Etap II stanowiły badania pilotażowe, realizowane za pomocą kwestionariusza ankiety skonstruowanego w etapie I, co przedstawia rysunek 2 .

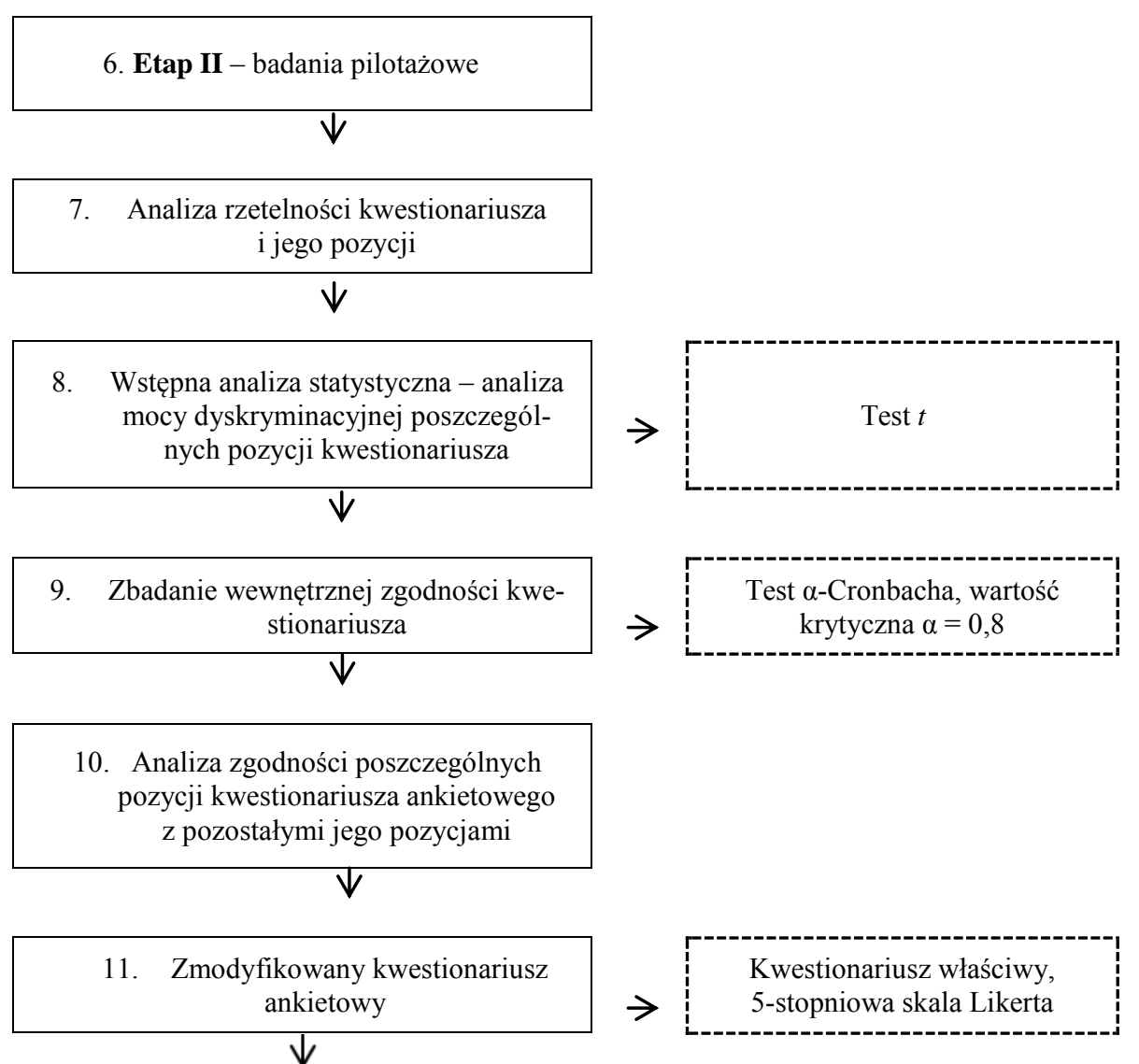

Rys. 2. Schemat badań pilotażowych 
Przeprowadzona została analiza rzetelności skonstruowanego narzędzia pomiarowego oraz jego poszczególnych pozycji, a także weryfikacja komunikatywności twierdzeń w nim występujących, co umożliwi w przyszłości prawidłowe zrealizowanie badań zasadniczych. Dokonano wstępnej analizy statystycznej, gdzie:

- przeprowadzono analizę mocy dyskryminacyjnej poszczególnych pozycji kwestionariusza za pomocą testu $t$;

- zbadano wewnętrzną zgodność kwestionariusza w oparciu o jedną z miar rzetelności skal z pozycjami wielokategorialnymi, tj. współczynnik $\alpha$-Cronbacha;

- wykonano analizę zgodności poszczególnych pozycji kwestionariusza ankietowego z pozostałymi jego pozycjami, tj. analizą współczynników korelacji z wynikiem sumarycznym, który można osiągnąć, gdy dana pozycja zostałaby pominięta.

W tym celu została pobrana próba o liczebności 33 osób, będących pracownikami firm korzystających z usług transportowych z terenu województwa lubelskiego.

W ten sposób uzyskano ankiety, które w kolejnych krokach badań pilotażowych proponowanej procedury badawczej (etapy $7,8,9,10$ ) poddane zostały wstępnej analizie statystycznej. Umożliwiło to analizę komunikatywności poszczególnych twierdzeń kwestionariusza, ich rzetelności oraz weryfikację narzędzia pomiarowego.

\section{Analiza uzyskanych wyników}

Lista cech pierwotnych, które przyporządkowano do pięciu podstawowych wymiarów modelu SERVQUAL, stanowiąca pierwszy etap budowy kwestionariusza ankietowego, została zmodyfikowana w oparciu o badania focusowe. Zgodnie $\mathrm{z}$ ich zasadą zachowano różnorodność badanych (15 respondentów), aby uzyskać dobrą dynamikę procesów grupowych, a więc także wartościowe wyniki badania. Na podstawie pierwszego etapu badań skonstruowano narzędzie pomiarowe w postaci autorskiego kwestionariusza ankietowego o następujących właściwościach:

-31 pozycji - twierdzenia o pozytywnych konotacjach;

$-\mathrm{z}$ uwagi na niejednoznaczne rozumienie przez respondentów $\mathrm{w}$ badaniach focusowych kilku pozycji $\mathrm{w}$ badaniach pilotażowych zrezygnowano $\mathrm{z}$ tych stwierdzeń;

- uzupełniono listę cech pierwotnych o jedno stwierdzenie;

- do oceny twierdzeń zastosowana została 5-stopniowa skala Likerta.

Ponadto stwierdzono, że zastosowany kwestionariusz można określić jako rzetelne narzędzie pomiarowe - o czym świadczy wartość współczynnika $\alpha$-Cronbacha $\alpha c=0,892$, co przedstawia wykres (rys. 3). 


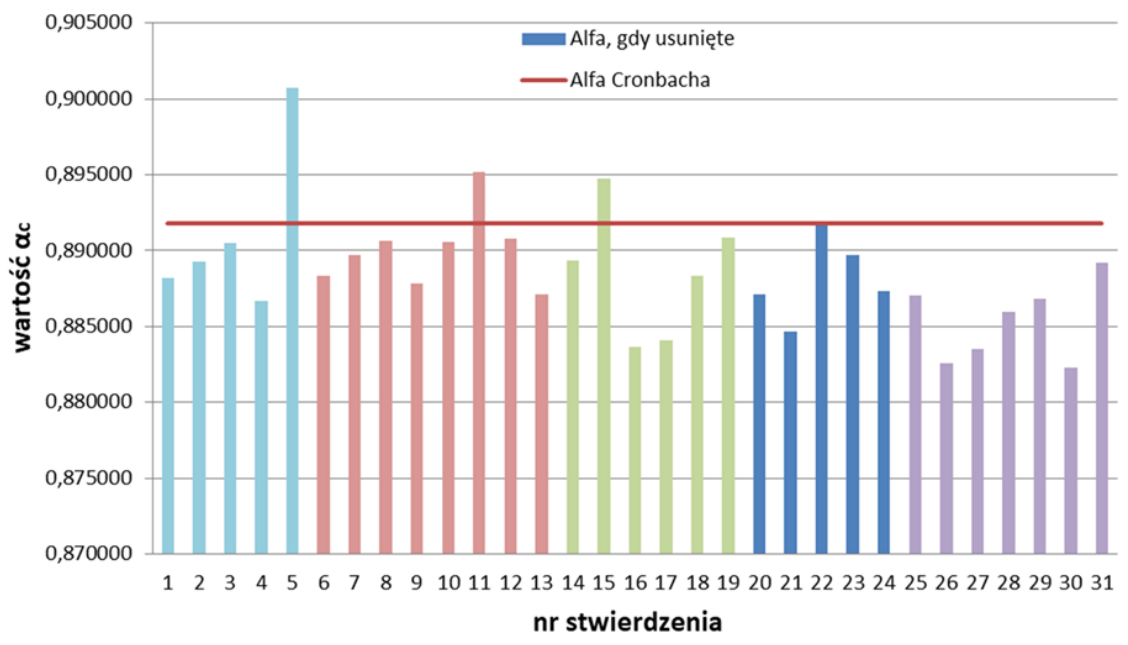

Rys. 3. Wyniki analizy rzetelności kwestionariusza ankietowego i jego pozycji, badania pilotażowe

Należy podkreślić, że wyniki analizy mocy dyskryminacyjnej poszczególnych pozycji kwestionariusza, przy wykorzystaniu jednej z kategorii cech jaką są kwartyle (dolny i górny), przy użyciu testu t, nie dały podstawy do usunięcia żadnego ze stwierdzeń. W niewielkim stopniu różnicowałyby one respondentów o pozytywnej postawie wobec rozważanego stwierdzenia od osób o postawie negatywnej wobec niego.

Z kolei analiza zgodności poszczególnych pozycji kwestionariusza, w oparciu o jedną z miar rzetelności skal z pozycjami wielokategorialnymi, tj. współczynnik $\alpha$-Cronbacha, dała podstawy do usunięcia jednego ze stwierdzeń, ponieważ obniżało to jego wartość.

\section{Wnioski}

Gospodarka stawia przed usługami transportowymi coraz większe wyzwania, które wynikają z rosnącego wolumenu produkcji, a także poziomu specjalizacji i kooperacji produkcji. Funkcjonowanie przedsiębiorstw branży transportowej w obecnych czasach wymusza ciągły monitoring wymagań rynkowych, których spełnienie pozwoli im przetrwać na rynku. Wówczas większość firm decyduje się na outsourcing. Jest to rodzaj współpracy pomiędzy przedsiębiorstwami, polegający na przekazaniu części działalności przedsiębiorstwa, w ramach kontraktu, zewnętrznemu usługodawcy. Przejmuje on wówczas odpowiedzialność za określone funkcje lub procesy. Zasadne staje się stworzenie metodyki badawczej dla pomiaru i oceny jakości usług transportowych w sektorze rolno-spożywczym. Zaproponowany model może zostać wykorzystany jako 
narzędzie do formułowania przez firmy transportowe strategii konkurencji oraz do kształtowania polityki produktowej.

Nieustanne badania satysfakcji klientów, w związku ze zrealizowaną usługą transportową, przyczyniają się do zgłębienia wiedzy z zakresu wymogów jakościowych, co umożliwia nieustanny rozwój usług transportowych na współczesnym, konkurencyjnym rynku i w nieustannie zmieniających się warunkach gospodarczych. Aktualnie nie ma jednej uniwersalnej ścieżki, która umożliwiłaby efektywne funkcjonowanie firmy w każdych warunkach. Przedsiębiorstwa, które są w stanie osiągnąć przewagę konkurencyjną, dochodzą do tego różnymi drogami, stosując szeroki wachlarz dostępnych i różnorodnych działań. Osiągnięcie przewagi konkurencyjnej, kształtowanie pozycji przedsiębiorstwa na rynku, jest możliwe, jak się wydaje, dzięki wyznaczeniu charakterystyki wymiarowej oraz modelu jakości usług transportowych postrzeganych przez przedsiębiorstwa funkcjonujące na rynku rolno-spożywczym. Jest to potencjalne narzędzie do wzrostu jego konkurencyjności, podstawa do poprawy i doskonalenia poziomu jakości usługi transportowej, a także możliwości poszerzania obszaru świadczonych usług. Indywidualne podejście do klienta, wynikające ze specyfiki branży usług transportowych, jest wymogiem koniecznym. Należy pamiętać, że to klient decyduje o kryteriach jakości usług transportowych i to od niego uzależniony jest popyt na usługę w tym zakresie.

Sama problematyka badań jakości usług transportowych jest zagadnieniem podejmowanym niejednokrotnie przez naukowców, ale w warunkach wolnego wyboru na rynku nabiera szczególnego znaczenia, z uwagi na możliwość zbudowania przewagi konkurencyjnej.

\section{Bibliografia}

Asubonteng P., McCleary K.J., Swan J.E., 1996. SERVQUAL revisited: A critical review of service quality. J. Serv. Market. 10(6), 62-81.

Czubała A., Jonas A., Smoleń T., Wiktor J., 2006. Marketing usług. Wolters Kluwers, Kraków, 116.

Doroszewicz S., Stoma M., 2007. Charakterystyka wymiarowa usługi ubezpieczenia autocasco spostrzeganej przez klientów indywidualnych. Studia i prace kolegium zarządzania i finansów. Zesz. Nauk. 81, SGH w Warszawie.

Frąś J., 2014. Wybrane instrumenty pomiaru jakości usług logistycznych. Zesz. Nauk. Uniw. Szczec. 803, Finanse, Rynki Finansowe, Ubezp. 66.

Kiełbasa M., 2015. Przyszłość sektora rolno-spożywczego w Polsce w odniesieniu do stanu obecnego. Prog. Econ. Sci. 2.

Karaszewski R., 2001. Servqual - metoda badania jakości świadczonych usług. Probl. Jakości 5, $8-10$.

Stajniak M., 2012. Standardy oceny jakości usług transportowych wg metody SERVQUAL. Logistyka 2, 1015-1021.

Szymanowski W., 2008. Zarządzanie łańcuchem dostaw żywności w Polsce. Kierunki zmian. Difin, Warszawa, 287-288. 
Piotr Stefaniak ${ }^{1}$, Katarzyna Lisiecka $\mathbb{B}^{2}$

\title{
Analiza zmienności współrzędnych barwy ekstrudatów paszowych w zależności od warunków procesu
}

\author{
Analysis of color coordinates variability of feed extrudates depending on processing conditions
}

\begin{abstract}
Wstęp
W trakcie hodowli zwierząt w tuczu przemysłowym bardzo ważnym czynnikiem jest zastosowanie odpowiedniego procesu ich żywienia w celu zapewnienia zdrowego rozwoju z podawaniem pełnowartościowej paszy. W przemysłowej produkcji pasz stosuje się duże ilości soi genetycznie modyfikowanej, która zawiera duże ilości bardzo cennego $\mathrm{w}$ diecie zwierząt białka. W Polsce uprawa soi jest mocno ograniczona, dlatego jest ona importowana głównie z krajów Ameryki Południowej oraz USA. W 2014 import śruty sojowej wyniósł ok. 2 mln ton [Tyczewska $\mathrm{i}$ in. 2014]. Wynika to głównie $\mathrm{z}$ faktu, że istnieje problem z zaspokojeniem zapotrzebowania zwierząt na białko za pomocą lokalnych surowców. Miało się to zmienić w 2006 r., kiedy przyjęto „Ustawę o paszach”, która miała zabraniać skarmiania zwierząt paszami z roślin genetycznie modyfikowanych od 2008 r. Jednak ze względu na dużą zależność naszego rolnictwa od dostaw tego surowca zdecydowano się na przełożenie wprowadzenia tego zakazu początkowo na 2013 r., potem na 2019 r., a obecnym terminem jest styczeń 2021 r. [Topagrar 2018, Wirtualna Polska 2018]. Aby zapewnić odpowiednie przygotowanie polskiego rolnictwa na tę bardzo znaczącą zmianę, przez wszystkie te lata prowadzone są liczne badania oraz konferencje mające na celu lepsze wykorzystanie rodzimych źródeł surowców roślinnych do produkcji pasz wysokobiałkowych.

Zastosowanie obróbki ciśnieniowo-termicznej ma wiele ważnych zalet z punktu widzenia technologicznego i jakościowego. Do najważniejszych należy inaktywacja substancji antyodżywczych (inhibitory enzymów, m.in. inhibitory trypsyny oraz enzym ureaza). Wpływa to na zwiększenie przyswajalności białka z produktów ekstrudowanych nawet przez młode zwierzęta [Głos Wielkopolski 2016]. Zwiększa się strawność skrobi, ponieważ pod wpływem temperatury ulega ona skleikowaniu i staje się rozpuszczalna w wodzie. Rozbijane są także

\footnotetext{
${ }^{1}$ Katedra Techniki Cieplnej i Inżynierii Procesowej, Wydział Inżynierii Produkcji, Uniwersytet Przyrodniczy w Lublinie, piotrstefaniak97@gmail.com

${ }^{2}$ Katedra Techniki Cieplnej i Inżynierii Procesowej, Wydział Inżynierii Produkcji, Uniwersytet Przyrodniczy w Lublinie, katarzyna.zelizko@gmail.com
} 
cząsteczki tłuszczu oraz rozrywane struktury włókna, co umożliwia lepsze ich wykorzystanie przez układ trawienny zwierząt [Mościcki i in. 2007]. Poza tym krótkotrwałe działanie wysokiej temperatury i wysokiego ciśnienia w ekstruderze powoduje częściową denaturację białek, co prowadzi do podniesienia wartości energetycznej produktu. Niszczona jest także duża ilość bakterii, pleśni i mikroorganizmów szkodliwych, co zwiększa trwałość i bezpieczeństwo mikrobiologiczne paszy [Farmet 2017]. Zastosowanie tego rodzaju produkcji zapewnia uniwersalność w przetwórstwie surowców dzieki mozliwości wytwarzania różnych kształtów ekstrudatów oraz dobrym warunkom do kontrolowania parametrów procesu [Mościcki i in. 2007].

Klimat w Polsce pozwala na uprawianie większości roślin strączkowych na terenie całego kraju, dlatego ciągle dąży się do zwiększenia ilości pól uprawnych tych surowców [Księżak 2013]. Powierzchnia upraw roślin strączkowych (bez soi) w 2004 r. wynosiła ok. 107 tys. ha, a w 2017 r. ok. 272 tys. ha [Bębenista i Augustyńska 2019]. Najważniejszą cechą takich roślin jest wysoka zawartość białka, która w grochu wynosi ok. $21 \%$, w bobiku $27-30 \%$, a w łubinie żółtym nawet do 44\% [Księżak 2013, Farmet 2015]. Ekstruzja umożliwia wykorzystanie tych surowców do wytwarzania pasz wysokobiałkowych, co pozwoliłoby w przyszłości ograniczyć lub nawet całkowicie wyeliminować zależność rodzimej gospodarki rolnej od dostaw soi genetycznie modyfikowanej z zagranicy.

Jednym z wyznaczników jakościowych produktów spożywczych i paszowych jest barwa oraz jej modyfikacje w zróżnicowanych warunkach przetwórstwa. Barwa jest to subiektywne wrażenie zmysłowe, które zależy od obserwatora i warunków, w jakich kolor jest obserwowany (przede wszystkim od źródła światła). Wrażenie barwy powstaje w mózgu i jest odpowiedzią na bodziec, jakim jest fala elektromagnetyczna o określonej długości odebrana przez receptory znajdujące się w oku. Mózg jest w stanie rozpoznać ok. 300-400 kolorów. Każdy człowiek w inny sposób ocenia barwę i nie musi być to spowodowane daltonizmem lub budową oka. Na przykład, gdy obserwujemy jasny przedmiot na tle ciemnego otoczenia, w jednakowych warunkach oświetlenia będzie się on wydawał jaśniejszy niż w rzeczywistości. Dlatego analiza sensoryczna przeprowadzana nawet przez wykwalikowanych specjalistów i uregulowana normami jest metodą subiektywną i z góry narażoną na błędy [Projekt - Ziarno 2015].

Aby unikać takich błędów, pomiary wykonuje się instrumentalnie, czyli przy użyciu specjalistycznych urządzeń do pomiaru barwy (kolorymetrów, spektrofotometrów). Pozwalają one na obiektywny, powtarzalny i precyzyjny pomiar oraz definiują barwę w postaci liczbowego opisu, wykorzystując do tego różne znormalizowane modele barw [Kazimierska 2014].

Zmiany barwy są związane ze zmianami fizycznymi, chemicznymi, biochemicznymi oraz mikrobiologicznymi, które występują podczas wzrostu, dojrzewania, pielęgnacji i procesu przetwarzania surowca. Pomiary barwy często są wykorzystywane do bezpośredniego określania jakości produktów. Są również wskaźnikiem intensywności obróbki cieplnej i mogą być stosowane do przewi- 
dywania obniżenia jakości wynikającej z ekspozycji na ciepło [Pathare i in. 2013]. System pomiaru barwy CIE-Lab jest powszechnie używany w przemyśle żywnościowym. Pozwala zachować niezależną identyfikację barw bez względu na stosowane urządzenie i łatwą konwersję danych na inne modele barw (np. RGB) [Pathare $\mathrm{i}$ in. 2013]. Model CIE-Lab jest to trójwymiarowa przestrzeń barw składająca się z trzech osi $L^{*}, a^{*}$ oraz $b^{*}$. Dwie współrzędne $a^{*}$ i $b^{*}$ są pod kątem prostym do siebie i opisują tonację (chromatyczność) barwy. Prostopadle do tej płaszczyzny znajduje się trzecia oś $L^{*}$, która określa poziom jasności (luminacji) [Kazimierska 2014]. Parametr $a^{*}$ przyjmuje wartości dodatnie dla czerwonawych kolorów i wartości ujemne dla zielonkawych, podczas gdy $b^{*}$ przyjmuje wartości dodatnie dla żółtawych kolorów i ujemne dla niebieskawych. $L^{*}$ to przybliżony wskaźnik jasności, według którego każda barwa ma konkretny odcień szarości. Wartości $L^{*}$ mieszczą się od 0 dla koloru czarnego do 100 dla barwy białej [Pathare i in. 2013].

Celem badań było zastosowanie wybranych roślin strączkowych (grochu, łubinu oraz bobiku) do wytworzenia ekstrudatów paszowych i określenie zmiany barwy w zależności od warunków procesu oraz poziomu dowilżenia surowców. Badanie barwy przeprowadzono instrumentalnie, wyznaczono współrzędne chromatyczne, wskaźnik różnicy barwy, stopień nasycenia oraz odcień barwy ekstrudatów z rodzimych surowców wysokobiałkowych.

\section{Materiały i metody}

Podczas badań do uzyskania ekstrudatów paszowych wykorzystano trzy surowce: groch, łubin oraz bobik zakupione na lokalnym rynku. Zostały one poddane procesowi przesiewania za pomocą sit o różnej wielkości oczek, co pozwoliło na oddzielenie wszelkich zanieczyszczeń oraz materiału drobnego i niepełnowartościowego.

Surowce rozdrobniono w rozdrabniaczu bijakowym z użyciem sit o wymiarach oczek $4 \mathrm{~mm}$, a następnie dowilżono odpowiednią ilość wody do wilgotności 12\% i 15\%. Proces ekstruzji prowadzono w ekstruderze jednoślimakowym TS-45 (Metalchem, Gliwice) z matrycą formującą o średnicy $4 \mathrm{~mm}$, w zakresie temperatur $130-150^{\circ} \mathrm{C}$. Stosunek długości do średnicy ślimaka układu plastyfikującego (L/D) wynosił 16. Podczas pracy urządzenia stosowano różne prędkości obrotowe ślimaka wynoszące 90, 100 i $120 \mathrm{obr} \mathrm{min}{ }^{-1}$. Otrzymane ekstrudaty paszowe ostudzono, rozdrobniono i poddano analizie barwy.

Badaniom poddano surowce nieprzetworzone oraz przetworzone. Barwę materiału określono za pomocą kolorymetru typu Supercolor (Braive Instruments, Belgia) w skali CIE-Lab. Pomiar był prowadzony w 10 powtórzeniach dla każdego surowca oraz w przypadku ekstrudatów w zależności od zastosowanej wilgotności oraz prędkości obrotowej ślimaka. Uzyskane współrzędne barwy dla materiału surowego uśredniono i przyjęto jako próbki kontrolne. 
Z zastosowaniem skali CIE-Lab wyznaczono współrzędne barwy $L^{*}, a^{*}, b^{*}$ w zakresie od 0 do 100 dla jasności $L^{*}$, dla współrzędnej $a^{*}(+)$ - barwa czerwona (-) - barwa zielona, dla współrzędnej $b^{*}(+)$ - barwa żółta $(-)$ - barwa niebieska.

Dzięki danym uzyskanym z układu CIE-Lab wyznaczono wskaźnik różnicy barwy $\Delta E$ między barwą surowca i otrzymanego ekstrudatu za pomocą wzoru [Wójtowicz i in. 2013]:

$$
\Delta E=\sqrt{\left(L_{\text {próbki }}^{*}-L_{\text {kontrolne }}^{*}\right)^{2}+\left(a_{\text {próbki }}^{*}-a_{\text {kontrolne }}^{*}\right)^{2}+\left(b_{\text {próbki }}^{*}-b_{\text {kontrolne }}^{*}\right)^{2}}
$$

$\Delta E$ jest to wektor odległości między dwoma punktami barw określonymi za pomocą wartości $L^{*}, a^{*}, b^{*} \mathrm{w}$ przestrzeni trójwymiarowej. Różnice w postrzeganej barwie można sklasyfikować analitycznie jako:

$-\Delta E<1$ - brak widocznej różnicy barw, niewidoczna różnica barw,

$-1<\Delta E<2$ - dość mała różnica zauważalna tylko przez doświadczonego obserwatora,

$-2<\Delta E<3,5$ - różnica, którą może zobaczyć przeciętny obserwator,

$-3,5<\Delta E<5$ - zauważalna wyraźna różnica barw,

$-5>\Delta \mathrm{E}$ - barwy odbierane jako zupełnie różne [Chudy 2016].

Dodatkowo, dzięki zastosowanemu modelowi barw obliczono stopień nasycenia $C^{*}$ i odcień barwy $h^{*}$ w celu całościowego opisu barwy analizowanych materiałów.

Stopień nasycenia (ang. chroma) $C^{*}$ jest to ilościowy wskaźnik zabarwienia, który służy do określenia stopnia różnicy odcienia w porównaniu z szarym kolorem o tej samej jasności. Barwa szara znajduje się w środku układu CIE-Lab, czyli wartość $C^{*}$ jest to odległość między tym punktem a położeniem badanej barwy [Pathare i in. 2013]. Oblicza się go za pomocą wzoru:

$$
C^{*}=\sqrt{a^{* 2}+b^{* 2}}
$$

Im wyższa jest wartość nasycenia, tym większa jest odległość od środka układu, a intensywność kolorów postrzegana przez człowieka rośnie (barwa jest czystsza, głębsza). Barwy mniej nasycone wydają się bardziej szare [Chudy 2016].

Odcień barwy jest wyrażany jako kąt tonu $h^{*}$ (ang. hue angle). Jest to jakościowa właściwość koloru służąca do zdefiniowana różnicy konkretnej barwy w odniesieniu do koloru szarego o tej samej jasności. Wartość $h^{*}$ jest to kąt między odcinkiem $C^{*}$ a odcinkiem dla barwy czerwonej, którego wartość kąta przyjmuje się za zero: 


$$
h^{*}=\operatorname{arctg}\left(\frac{b^{*}}{a^{*}}\right)
$$

Wartość otrzymanego kąta można sklasyfikować:

- kąt $0^{\circ}$ lub $360^{\circ}$ reprezentuje odcień czerwony,

- kąt $90^{\circ}$ odcień żółty,

- kąt $180^{\circ}$ odcień zielony,

- kąt $270^{\circ}$ odcień niebieski.

Parametr ten pozwala określić, w kierunku jakiego koloru bardziej odchylona jest badana barwa [Pathare $i$ in. 2013].

Za pomocą stopnia nasycenia $C^{*}$ i kąta tonu $h^{*}$ obliczono różnicę w nasyceniu oraz kącie tonu między surowcem a otrzymanym ekstrudatem. $\Delta C^{*}$, czyli różnica nasycenia, przyjmuje wartości dodatnie i ujemne. Wartość ujemna tego współczynnika oznacza, że kolor jest bledszy (mniej nasycony) od próbki kontrolnej. Natomiast wartość dodatnia oznacza, że kolor jest żywszy (bardziej nasycony) niż próbka kontrolna. $\Delta h$, czyli różnica kąta tonu, odpowiada odchyleniu kątowemu dwóch porównywanych barw.

Wyniki badania poddano analizie $\mathrm{z}$ wykorzystaniem arkusza kalkulacyjnego firmy Microsoft Excel.

\section{Wyniki i dyskusja}

Wyniki pomiaru składowych barwy surowców były następujące: groch $L^{*}=$ $90,60, a^{*}=4,73, b^{*}=18,52$, tubin $L^{*}=77,78, a^{*}=5,73, b^{*}=23,25$, bobik $L^{*}$ $=81,97, a^{*}=4,34, b^{*}=16,49$. Pomiar barwy wykazał, że w wyniku ekstruzji barwa zmienia się $\mathrm{w}$ różny sposób w zależności od surowca oraz poziomu jego dowilżenia. Nie zanotowano idealnego zrównania się barw w żadnym przypadku, ponieważ wymaga to zgodności wszystkich trzech parametrów barwy. Każda badana próbka została obarczona pewną odchyłką kolorystyczną.

Na rysunku 1 zestawiono zmiany wartości współczynnika jasności $\mathrm{L}^{*} \mathrm{w}$ zależności od stosowanych obrotów ślimaka w ekstruderze i wilgotności dla trzech analizowanych surowców (grochu, łubinu i bobiku). Najwyższą jasnością charakteryzowały się ekstrudaty grochowe, prędkość obrotowa w tym przypadku nie wpływała znacznie na zmianę jasności produktu w obu wariantach wilgotności. Dla łubinu zanotowano wzrost jasności dla surowca o wilgotności $12 \%$ i $15 \%$, podczas zwiększania obrotów ślimaka. Widoczna jest także różnica w jasności tego surowca w zależności od zastosowanej wilgotności. Ekstrudat powstały z łubinu o większej wilgotności jest ciemniejszy. W przypadku bobiku zaobserwowano ciemnienie barwy ekstrudatu, więc zachowanie odwrotne do pozostałych surowców, przy czym ciemnienie było intensywniejsze przy dowilżeniu bobiku do $12 \%$. Zmiany koloru następują m.in. przez rozkład składników decydujących o kolorze oraz w wyniku przemian składników z powodu działania wysokiej temperatury i ciśnienia. 

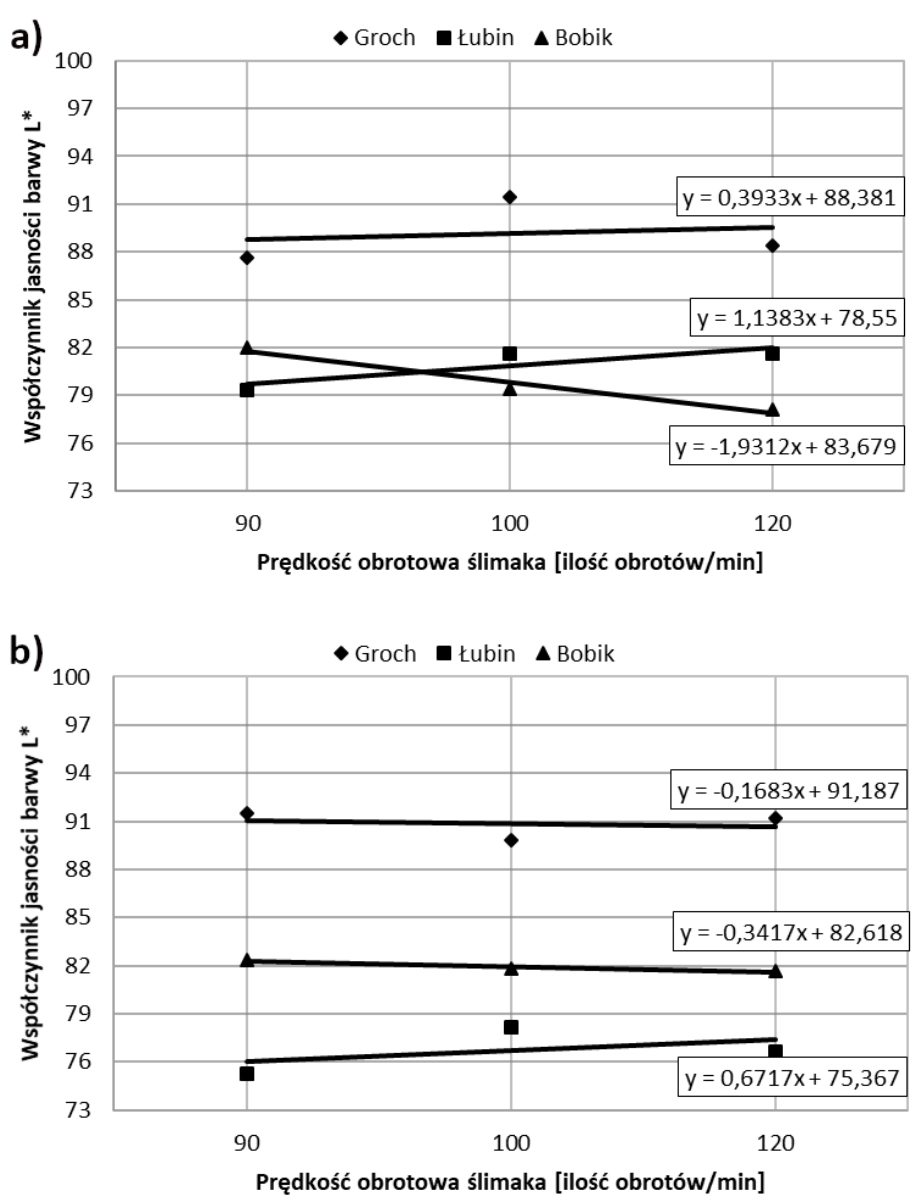

Rys. 1. Wyniki pomiaru jasności $L^{*}$ w zależności od zastosowanych surowców, prędkości obrotowej ślimaka i poziomu dowilżenia: a) $12 \%$, b) $15 \%$

Na rysunkach 2a i 2b można zaobserwować tendencję spadkową składowej barwy $a^{*}$ dla ekstrudatów z grochu, czyli obniżanie intensywności barwy czerwonej. Spadek zachodził gwałtowniej przy dowilżeniu 15\%. Ekstrudat z łubinu o większej wilgotności początkowej surowca charakteryzował się większym natężeniem barwy czerwonej w stosunku do wilgotności 12\%. Zmiana obrotów ślimaka nie miała znaczącego wpływu na wartość parametru $a^{*}$ dla ekstrudatów z łubinu oraz bobiku. W przypadku bobiku dla obydwu poziomów dowilżenia wartość składowej $a^{*}$ była na podobnym poziomie.

Największą intensywność barwy żółtej $b^{*}$ zaobserwowano w przypadku łubinu, była ona zbliżona przy obydwu zastosowanych poziomach dowilżenia, nie obserwowano tu wpływu zmiennej prędkości obrotowej ślimaka (rys. 3). Zanotowano niewielki spadek intensywności barwy żółtej w ekstrudatach z grochu wraz ze wzrostem obrotów ślimaka. W przypadku bobiku zaobserwowano wzrost 
intensywności składowej barwy $b^{*}$ przy zwiększaniu prędkości obrotowej, przy czym tendencja ta była bardziej istotna przy zastosowaniu surowców dowilżonych do wilgotności $15 \%$.
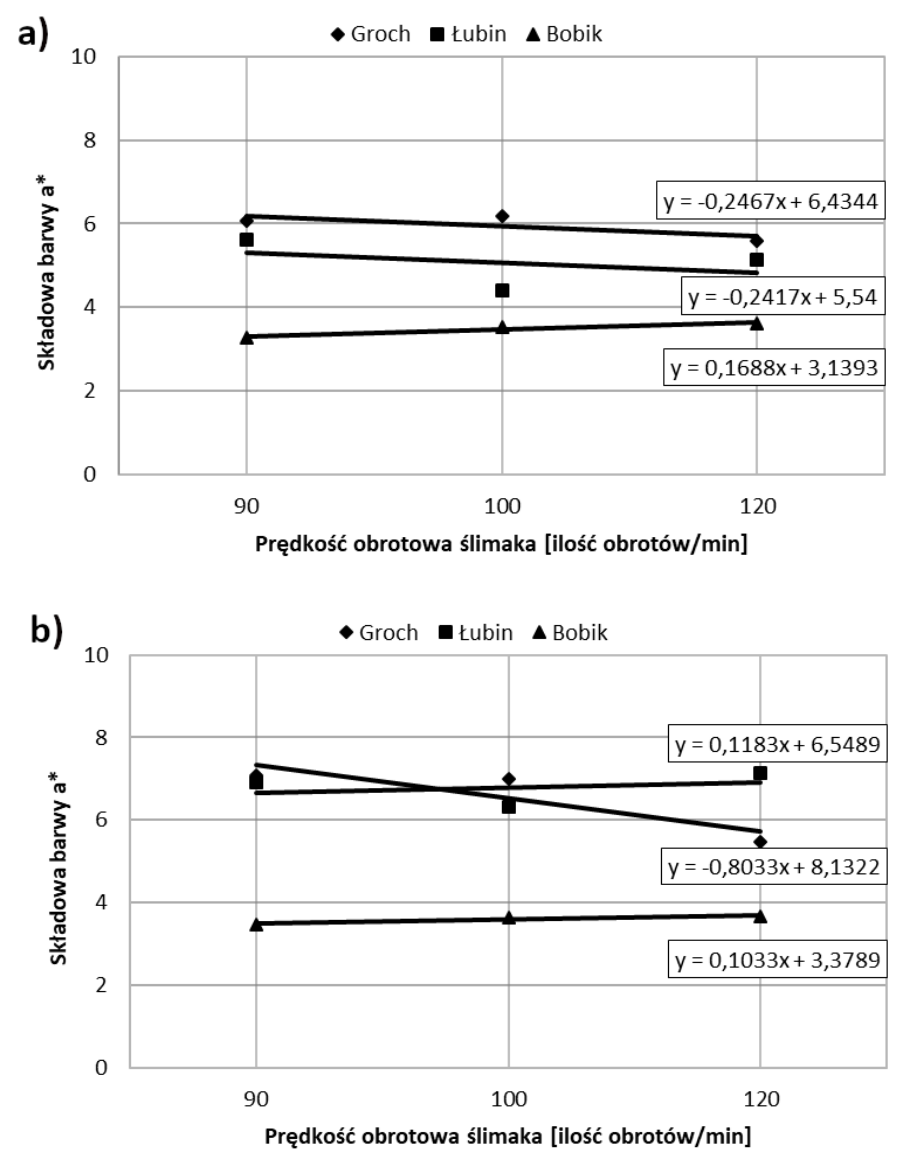

Rys. 2. Wyniki składowej barwy $a^{*} \mathrm{w}$ zależności od zastosowanych surowców, prędkości obrotowej ślimaka i poziomu dowilżenia: a) $12 \%$, b) $15 \%$

Porównano barwę surowców i ekstrudatów z nich wytworzonych za pomocą obliczenia różnicy barwy $\Delta E$, różnicy nasycenia $\Delta C^{*}$ oraz różnicy kąta tonu $\Delta h *$. Wyniki zestawiono w tabeli 1 . Ekstruzja najbardziej wpłynęła na zmianę barwy w przypadku łubinu, gdzie $\Delta E$ wynosiła 6,38 przy $12 \%$ wilgotności materiału oraz 6,25 przy dowilżeniu do $15 \%$. Oznacza to, że w tym przypadku występuje wrażenie dwóch różnych barw. W przypadku grochu $\Delta E$ wyniosła 4,25 (dla 12\% wilgotności materiału) oraz 4,62 (dla 15\% wilgotności materiału). Obserwowano wyraźną różnicę barw mimo niższej wartości tego współczynnika. Najmniej proces wpłynął na zmianę barwy bobiku, gdzie zanotowano niewielką różnicę w barwie. W przypadku bobiku dowilżonego do wilgotności 12\% 

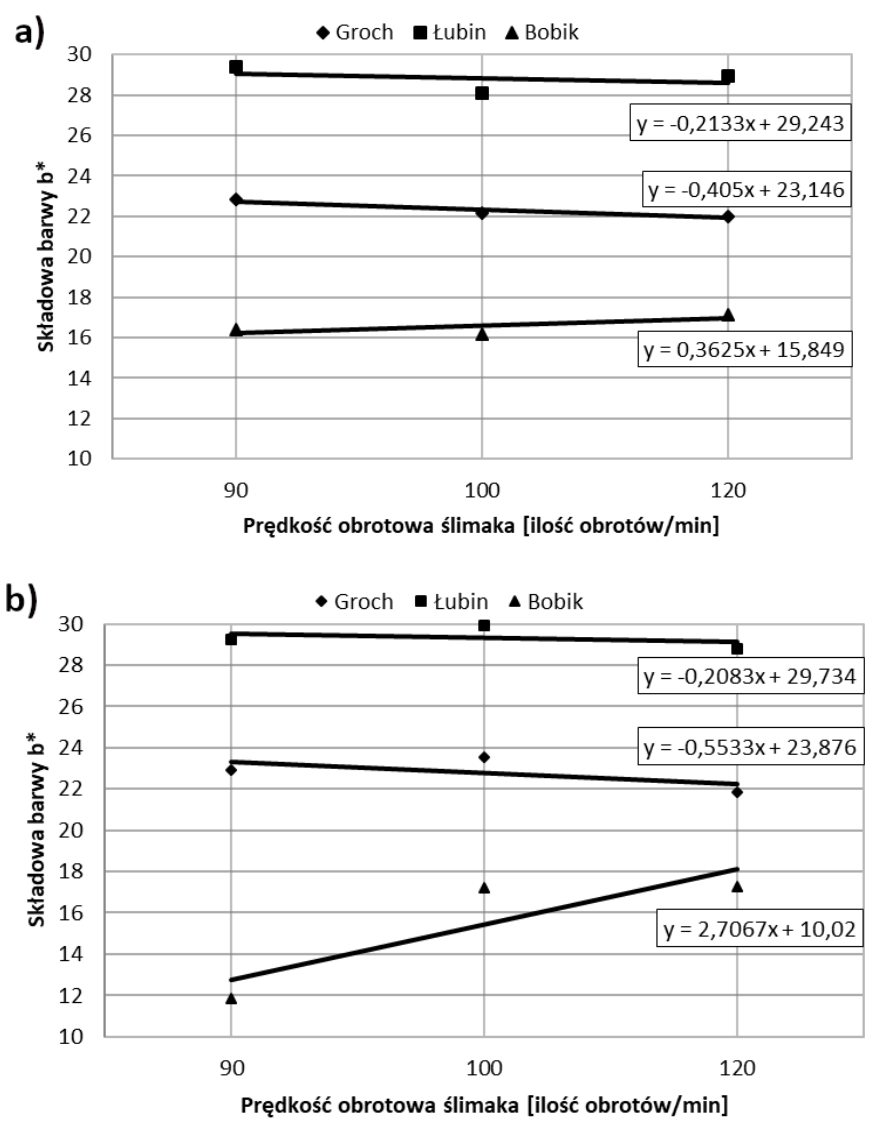

Rys. 3. Wyniki składowej barwy $b^{*} \mathrm{w}$ zależności od zastosowanych surowców, prędkości obrotowej ślimaka i poziomu dowilżenia: a) $12 \%$, b) $15 \%$

Tabela 1. Średnie wartości współrzędnych barwy surowców i ekstrudatów z roślin strączkowych

\begin{tabular}{|l|c|c|c|c|c|c|}
\hline \multirow{2}{*}{ Surowiec } & \multirow{2}{*}{$\begin{array}{c}\text { Wilgotność } \\
\text { wstępna }\end{array}$} & \multicolumn{5}{|c|}{ Współrzędne barwy } \\
\cline { 3 - 7 } Groch & surowy & 19,11 & 75,68 & ref. & ref. & ref. \\
& $12 \%$ & 23,11 & 75,10 & 4,00 & $-0,58$ & 4,26 \\
& $15 \%$ & 23,69 & 74,01 & 4,57 & $-1,67$ & 4,62 \\
\hline \multirow{3}{*}{ Lubin } & surowy & 23,94 & 75,68 & ref. & ref. & ref. \\
& $12 \%$ & 29,26 & 80,05 & 5,31 & 4,36 & 6,38 \\
& $15 \%$ & 30,09 & 76,97 & 6,15 & 1,29 & 6,25 \\
\hline \multirow{3}{*}{ Bobik } & surowy & 17,05 & 75,25 & ref. & ref. & ref. \\
& $12 \%$ & 16,93 & 78,15 & $-0,11$ & 2,90 & 2,32 \\
& $15 \%$ & 15,84 & 76,92 & $-1,20$ & 1,67 & 1,30 \\
\hline
\end{tabular}


różnicę może zobaczyć przeciętny obserwator, ale przy dowilżeniu do wilgotności $15 \%$ musi być to doświadczony obserwator, aby zanotować różnicę barw.

Stopień nasycenia $C^{*}$ także zmieniał się różnie dla poszczególnych surowców. W przypadku grochu przez działanie ekstruzji nasycenie barwy stało się intensywniejsze w stosunku do barwy materiału surowego, wartość $C^{*}$ zwiększała się wraz ze zwiększaniem wilgotności wstępnej surowca. Podobna tendencja miała miejsce w przypadku łubinu. Natomiast przy zastosowaniu bobiku proces ekstruzji powodował dążenie barwy do szarości. Tendencja ta była widoczna wraz ze wzrostem wilgotności wstępnej surowców.

Kąt tonu dla wszystkich badanych materiałów wahał się pomiędzy $74,01^{\circ}$ a $80,05^{\circ}$, co oznacza, że badane surowce i ekstrudaty miały odcień bliższy barwie żółtej. Jednak proces ekstruzji różnie wpływał na wartość tego parametru. W przypadku grochu kąt tonu malał wraz ze zmianą wilgotności w stosunku do materiału surowego. Dla łubinu i bobiku zanotowano wzrost tego parametru w ekstrudatach, czyli dążenie do żółtego odcienia.

\section{Wnioski}

Badania wykazały, że proces ekstruzji wpływał w różny sposób na barwę otrzymanego ekstrudatu nawet dla surowców względnie podobnych do siebie należących do roślin strączkowych. Zdecydowanie największe zmiany zaobserwowano w przypadku łubinu oraz grochu, gdzie proces ekstruzji spowodował istotne zmiany barwy. Prędkość obrotowa ślimaka podczas ekstruzji miała różny wpływ na barwę. Zwiększanie prędkości podczas ekstruzji grochu powodowało obniżenie intensywności odcienia czerwonego, natomiast w przypadku bobiku - obniżenie jasności oraz wzrost intensywności barwy żółtej. Zanotowano także wpływ wilgotności wstępnej surowca na barwę produktu gotowego. Pod wpływem ekstruzji zwiększał się stopień nasycenia barw przetworzonego grochu oraz łubinu w stosunku do materiału surowego. W przypadku bobiku barwa stawała się mniej intensywna. Odcień wszystkich badanych materiałów bliższy był barwie żółtej. Ekstrudaty charakteryzowały się niewielką zmianą kąta tonu w stosunku do materiału początkowego.

\section{Bibliografia}

Bębenista A., Augustyńska I., 2019. Rośliny strączkowe - efektywność ich uprawy w wybranych gospodarstwach rolnych w Polsce. Seminarium, Instytut Ekonomiki Rolnictwa i Gospodarki Żywnościowej - Państwowy Instytut Badawczy w Warszawie.

Bisharat G., Katsavou I., Panagiotou N., Krokida M., Maroulis Z., 2015. Investigation of functional properties and color changes of corn extrudates enriched with broccoli or olive paste. Food Sci. Tech. Int. 21, 613-630. www.doi.org/10.1177/1082013214559310 
Chudy S., 2016. Pomiar barwy produktów mleczarskich. W: Współczesne trendy w kształtowaniu jakości żywności, Piasecka-Kwiatkowska D., Cegielska-Radziejewska R. (red.). Wydział Nauk o Żywności i Żywieniu UP w Poznaniu, Poznań, 85-95.

Farmet, 2017. Ekstruzja pasz. https://www.farmet.cz/pl/oft/ekstruzja-pasz [data dostępu: 9.03.2020].

Farmet, 2015. Bobik - niedoceniane źródło białka w żywieniu tuczników, https://www.farmer.pl/produkcja-zwierzeca/trzoda-chlewna/bobik-niedoceniane-zrodlo-bialka-w-zywieniu-tucznikow,61727.html [data dostępu: 9.03.2020].

Głos Wielkopolski, 2016. Ekstruzja - sposób na soję. https://gloswielkopolski.pl/ekstruzja-sposobna-soje/ar/10545834 [data dostępu: 9.03.2020].

Kazimierska M. (red.), 2014. Obiektywna ocena barwy wyrobów użytkowych. Technologia i Jakość Wyrobów 59, 44-47.

Mościcki L., Mitrus M., Wójtowicz A., 2007. Technika ekstruzji w przemyśle rolno-spożywczym. PWRiL, Warszawa.

Pathare P., Opara U., Al-Said F., 2013. Colour measurement and analysis in fresh and processed foods: a review. Food Biop. Tech. 6, 63-71. www.doi.org/10.1007/s11947-012-0867-9 [data dostępu: 9.03.2020].

Księżak J. (red.), 2013. Uprawa roślin strączkowych w Polsce. FAPA, Warszawa.

Projekt - Ziarno, 2015. Pomiar barwy. http://ziarno.edu.pl/index.php/analiza-obrazu/pomiar-barwy [data dostępu: 9.03.2020].

Topagrar, 2018. Zakaz stosowania pasz GMO od 2021 roku. https://www.topagrar.pl/articles/zywienieswin/zakaz-stosowania-pasz-gmo-od-2021-roku/ [data dostępu: 9.03.2020].

Tyczewska A., Gracz J., Twardowski T., Małyska A. (red.), 2014. Soja przyszłością polskiego rolnictwa? Nauka 4, 121-138.

Wójtowicz A., Kolasa A., Moscicki L., 2013. Influence of buckwheat addition on physical properties, texture and sensory characteristics of extruded corn snacks. Pol. J. Food Nutr. Sci. 63, 239-244. www.doi.org/10.2478/v10222-012-0076-2 [data dostępu: 9.03.2020].

Wirtualna Polska, 2018. Pasza z soją GMO - od stycznia nie będzie można nią karmić zwierząt, https://wiadomosci.wp.pl/pasza-z-soja-gmo-od-stycznia-nie-bedzie-mozna-nia-karmiczwierzat-6313684811888257a?nil= [data dostępu: 9.03.2020]. 
Magdalena Stobiecka $\mathbb{1}^{1,3}$, Jan Zdulski® ${ }^{2}$, Joanna Wajs $\mathbb{D}^{1}$, Sylwia Jańczuk ${ }^{1}$

\title{
Zastosowanie i właściwości kwiatów chabra bławatka (Centaurea cyanus)
}

Use and properties of cornflower (Centaurea cyanus)

\begin{abstract}
Wstęp
Ważnym źródłem pokarmu w diecie człowieka są rośliny, przy czym wykorzystywane są głównie nasiona, owoce oraz ich części spichrzowe. Po kwiaty oraz liście sięgamy najczęściej w kontekście medycznym [Śmiechowska 2018]. W ostatnich latach zwiększyło się zainteresowanie kwiatami. Są one traktowane jako element dekoracji potraw i źródło wrażeń nie tylko estetycznych, ale także smakowych. W tabeli 1 przedstawiono kwiaty, które wykorzystywane są w żywieniu. Powszechnie kwiaty spotykamy już nie tylko jako dekoracje, ale również składnik dań lub oddzielne posiłki, np. sałatki kwiatowe. Na stołach goszczą: ogórek siewny, dynia zwyczajna, czarny bez, aksamitki, groszek jadalny, fiołek wonny, nagietek lekarski i lawenda wąskolistna.

Do najczęściej spotykanych produktów kwiatowych zalicza się herbaty (czarne, zielone i białe) z dodatkiem kwiatów [Nowicka i in. 2018]. Wsad kwiatowy może stanowić główny składnik herbat (hibiskus, rumianek, malwa) lub być traktowany jako składnik dodatkowy (kwiat nagietka, chabru). Przemysł spożywczy korzysta z kwiatów głównie jako barwników oraz dodatków poprawiających smak i właściwości produktu. W suplementach diety i żywności funkcjonalnej coraz częściej sięga się po płatki kwiatowe jako naturalne i ciekawe urozmaicenia. Dodatki te są bezpieczne, w przeciwieństwie do pewnych często kwestionowanych dodatków syntetycznych. Konsumenci sięgają po takie produkty z ciekawości oraz w trosce o swoje zdrowie [Nowicka i in. 2018, Śmiechowska 2018].

Przed spożyciem część kwiatów wymaga usunięcia pręcików, słupka i działek kielicha. W zależności od gatunku używa się całego kwiatostanu, samych płatków lub pojedynczych kwiatów [Wałejko 2015]. Kwiaty w dużej części, bo w ponad $80 \%$, składają się z wody. Zawartość białka i thuszczu jest natomiast bardzo niska. Udział błonnika pokarmowego, węglowodanów jest wysoce zróż-

\footnotetext{
${ }^{1}$ Instytut Oceny Jakości i Przetwórstwa Produktów Zwierzęcych, Wydział Nauk o Zwierzętach i Biogospodarki, Uniwersytet Przyrodniczy w Lublinie

${ }^{2}$ Zakład Hodowli i Ochrony Zasobów Genetycznych Bydła, Instytut Hodowli Zwierząt i Ochrony Bioróżnorodności, Wydział Nauk o Zwierzętach i Biogospodarki, Uniwersytet Przyrodniczy w Lublinie

${ }^{3}$ magdalena.stobiecka@student.up.edu.pl
} 
Tabela 1. Kwiaty jadalne wykorzystywane jako żywność [Grzeszczuk i in. 2010, Mleck i in. 2011, Rop i in. 2012, Śmiechowska 2018]

\begin{tabular}{|c|c|c|c|}
\hline Kwiaty & Nazwa łacińska & $\begin{array}{l}\text { Jadalne części } \\
\text { kwiatów }\end{array}$ & $\begin{array}{c}\text { Zastosowanie } \\
\text { w żywieniu }\end{array}$ \\
\hline Aksamitka & Tagetes & płatki & $\begin{array}{l}\text { do aromatyzowania } \\
\text { sałatek i deserów }\end{array}$ \\
\hline $\begin{array}{l}\text { Begonia } \\
\text { bulwiasta }\end{array}$ & $\begin{array}{l}\text { Begonia } \times \text { semperflo- } \\
\text { renscultorum hort }\end{array}$ & pojedyncze kwiaty & dekoracja dań i deserów \\
\hline $\begin{array}{l}\text { Bergamotka, } \\
\text { pysznogłówka } \\
\text { szkarłatna }\end{array}$ & Monarda didyma & płatki & $\begin{array}{l}\text { do aromatyzowania } \\
\text { herbat, deserów }\end{array}$ \\
\hline Bez czarny & Sambucus nigra L. & cały kwiatostan & $\begin{array}{l}\text { dekoracje dań i dese- } \\
\text { rów, sałatki, sok }\end{array}$ \\
\hline Bratek & Viola $\times$ wittrockiana & pojedyncze kwiaty & $\begin{array}{l}\text { dekoracja dań i dese- } \\
\text { rów, sałatki }\end{array}$ \\
\hline Chryzantema & Chryzanthemum spp. & pojedyncze kwiaty & dekoracja dań i deserów \\
\hline $\begin{array}{l}\text { Chaber } \\
\text { bławatek }\end{array}$ & Centaurea cyanus & płatki & dekoracja dań i deserów \\
\hline Kwiaty dyni & Cucurbita $\mathrm{L}$. & pojedyncze kwiaty & $\begin{array}{l}\text { dekoracja dań i dese- } \\
\text { rów, naleśniki i chipsy }\end{array}$ \\
\hline Goździk & Dianthus ssp. & $\begin{array}{l}\text { pojedyncze } \\
\text { kwiaty, płatki }\end{array}$ & $\begin{array}{l}\text { do aromatyzowania } \\
\text { deserów i ciast, cukru, } \\
\text { a także do sałatek, napo- } \\
\text { jów i przetworów owo- } \\
\text { cowych, garnirowania }\end{array}$ \\
\hline Kwiaty jeżówki & Echinacea purpurea & płatki & dekoracja dań \\
\hline Kwiaty lawendy & Lavandula angustifolia & $\begin{array}{l}\text { cały kwiatostan, } \\
\text { pojedynce kwiaty }\end{array}$ & $\begin{array}{l}\text { dekoracja dań i deserów, } \\
\text { lodów i napojów }\end{array}$ \\
\hline Liliowiec & Hemerocallis & $\begin{array}{l}\text { pojedyncze kwia- } \\
\text { ty, płatki i pąki }\end{array}$ & $\begin{array}{l}\text { dodatek do sałatek, pąki } \\
\text { spożywane jako goto- } \\
\text { wane, duszone lub } \\
\text { smażone }\end{array}$ \\
\hline Kwiaty nagietka & Calendula officinalis L. & płatki & $\begin{array}{l}\text { dekoracja dań i dese- } \\
\text { rów, sałatki, sok }\end{array}$ \\
\hline Kwiaty nasturcji & Tropaeolum majus L. & pojedyncze kwiaty & dekoracja dań, sałatki \\
\hline Kwiaty róży & Rosa spp. & płatki & $\begin{array}{l}\text { dekoracja dań i dese- } \\
\text { rów, lody, napoje, soki }\end{array}$ \\
\hline $\begin{array}{l}\text { Kwiaty } \\
\text { stokrotki }\end{array}$ & Bellis perennis L. & pojedyncze kwiaty & $\begin{array}{l}\text { dekoracja dań, sałatki, } \\
\text { napoje }\end{array}$ \\
\hline Szczypiorek & Allium schoenoprasum L. & $\begin{array}{l}\text { pojedyncze kwiaty, } \\
\text { płatki }\end{array}$ & dodatek do sałatek \\
\hline
\end{tabular}

nicowany i zależy od gatunku. Zaletą z punktu widzenia dietetyki jest fakt, że kwiaty jadalne i przygotowywane $\mathrm{z}$ nich napary nie zawierają substancji typu kofeina, teina czy innych środków pobudzających [Navarro-Gonzalez i in. 2015]. Oprócz walorów kulinarnych roślinne dodatki wprowadzają do naszej diety ważne składniki bioaktywne. Kwiaty jadalne są doskonałym źródłem składników mineralnych, zwłaszcza fosforu, magnezu, wapnia i potasu, a także manganu, miedzi, cynku i żelaza. Potas odgrywa ważną rolę, zapobiegając cho- 
robom układu sercowo-naczyniowego, a w połączeniu z sodem reguluje ciśnienie osmotyczne komórki. Makro- i mikroelementy korzystnie wpływają na układ odpornościowy organizmu. Kwiaty jadalne są również źródłem polifenoli. Jest to grupa substancji organicznych, która wykazuje silne właściwości antyoksydacyjne, wspomagające systemy obronne organizmu przed destrukcyjnym działaniem wolnych rodników. Ich spożywanie chroni przed zachwianiem równowagi antyoksydacyjnej, a tym samym zapobiega występowaniu szeregu chorób, tj. układu krążenia, nowotworowych czy cukrzycy. Poza polifenolami również karotenoidy stanowią cenny składnik kwiatów jadalnych. Charakteryzują się one cennymi właściwościami biologicznymi, m.in. łagodzą objawy retinopatii cukrzycowej, zwiększają peroksydację glutationu oraz obniżają poziom frakcji LDL cholesterolu, co finalnie przyczynia się do skutecznej profilaktyki przewlekłych chorób niezakaźnych [Nowicka i in. 2018].

\section{Kwiaty w diecie - rys historyczny}

Historia pokazuje, że już w 140 r. p.n.e. na Bliskim Wschodzie spożywano kwiaty drzewa pomarańczowego i róży, zaś w Chinach i Japonii największym uznaniem od wieków cieszyła się chryzantema, stanowiąca główny składnik tradycyjnej potrawy chop suey. Została ona uznana za kwiat narodowy Japonii, gdyż rodzima nazwa tego kraju - Nippon - znaczy tyle co zachodzące słońce, a kwiat ten swoim wyglądem właśnie je przypomina [Wałejko 2015]. Natomiast w starożytnym Rzymie czy Grecji kwiaty były wykorzystywane w celu wzmocnienia smaku, jako przyprawy potraw zarówno słonych, jak i słodkich. Liście ogórecznika stanowiły tam dodatek do wina podawanego żołnierzom przed bitwą [Nowicka i in. 2018]. W Hiszpanii pędy i liście ogórecznika, podawane po wcześniejszym duszeniu na maśle, są wciąż popularne [Wałejko 2015]. W środkowej Europie dużym uznaniem cieszyły się kwiaty czarnego bzu usmażone w cieście czy kwiaty mniszka lekarskiego gotowane w cukrze, stanowiące zamiennik miodu [Nowicka $\mathrm{i}$ in. 2018]. W Polsce już w okresie średniowiecza płatki róż ucierane były na konfitury, a napary z lipy i rumianku obecne są do dzisiaj. Co więcej, syrop z kwiatów czarnego bzu stosuje się w celu wzmocnienia odporności, napar $\mathrm{z}$ kwiatu kopru włoskiego przynosi ulgę w kolkach u niemowląt, a płatki hibiskusa stanowią częsty dodatek do herbat, nadając charakterystyczny kwaśny smak i intensywny kolor [Wałejko 2015]. Obecnie na rynku dostępnych jest 80 gatunków kwiatów jadalnych, należą do nich zarówno kwiaty ziół, warzyw, krzewów, drzew, jak i roślin ozdobnych [Wałejko 2015]. Można je nabyć w wielu formach: od świeżych, przez liofilizowane, suszone konwencjonalnie, krystalizowane, sproszkowane jako ekstrakt, syrop, aż po esencje kwiatowe. Te ostatnie wykorzystywane są głównie do przełamania, wzmocnienia lub dodania nowej nuty smakowej potrawie. Świeże można używać jedynie przez bardzo krótki okres, ze względu na fakt, iż są nietrwałe. Jednakże istnieje 
prosty sposób utrwalający - posmarowanie płatków białkiem jaja kurzego za pomocą pędzelka. Następnie wystarczy oprószyć je cukrem pudrem i wysuszyć. W takiej formie mogą być przechowywane w szczelnym opakowaniu w zaciemnionym miejscu. Aby proces ten był w pełni bezpieczny, należy użyć sproszkowanego pasteryzowanego białka i miękkiego pędzelka, który nie uszkodzi struktury płatków [Nowicka 2018]. Kwiaty jadalne charakteryzują się szeroką paletą barw i kształtów. Dzięki temu poprawiają smak i wygląd, a także mogą korzystnie wpływać na wartość odżywczą posiłków. Stąd też są one coraz częściej dodawane do deserów, sałatek czy napojów [Nowicka i in. 2018].

\section{Chaber blawatek - podstawowe informacje}

Chaber bławatek (Centaurea cyanus L.) zalicza się do rodziny Asteraceae (astrowate), jednej z największych rodzin w królestwie roślin. Pochodzi z Bliskiego Wschodu i rejonów Morza Śródziemnego. W Polsce występuje praktycznie we wszystkich regionach kraju. Ten popularny chwast często pojawia się w uprawach rzepaku, zbóż ozimych oraz roślin okopowych i motylkowych. Niestety wraz z postępującą chemizacją rolnictwa zaczyna znikać z krajobrazu wiejskiego. Jest rośliną zielną jednoroczną, słabo ulistnioną szaro owłosionymi lancetowatymi liśćmi, o prostej, ale rozgałęzionej łodydze. Dorasta do jednego metra wysokości. Kwiatostan stanowią koszyczki wyrastające pojedynczo na szczytach pędów. Złożone są z niewielkich kwiatów rurkowych oraz kwiatów języczkowych o barwie od niebieskiej do ciemnofioletowej, często określanej mianem niebieskochabrowej (rys. 1). Kwitnienie przypada na czas od maja do września. Dawniej kwiatów tych używano do produkcji barwnika. Owocem jest niełupka $\mathrm{z}$ charakterystycznym włosiem u nasady przypominającym pędzelek [Senderski 2004, Tomczak 2007, Józefczyk i in. 2018].

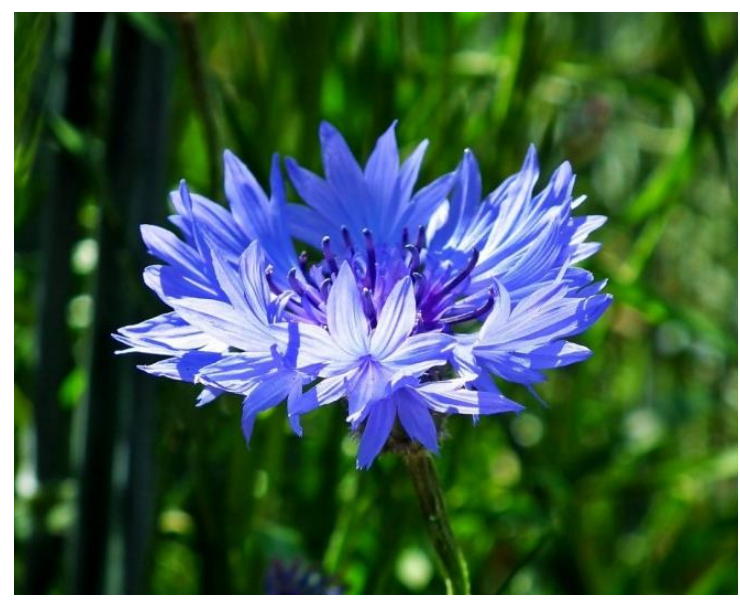

Rys. 1. Chaber bławatek [http://www.e-ogrodek.pl] 
Jego jadalną część stanowią jedynie płatki. W smaku może przypominać koniczynę. Najczęściej stosowany jest jako dodatek do herbat, a skrystalizowane płatki stanowią składnik deserów. Oprócz tego należy do roślin miododajnych, a ze względu na walory zapachowe stanowi dodatek do kadzideł [Wałejko 2015]. Rodzaj Centaurea L. występuje w Europie i Azji Zachodniej. Jest bardzo zróżnicowany, wykazuje wysoki współczynnik endemiczności. Gatunki należące do tego rodzaju szeroko wykorzystywane są w ludowej medycynie wielu krajów. Ze względu na swoją różnorodność oraz zmienność gatunkową takson wymaga dalszych cytologicznych i chemicznych badań, gdyż obecnie jego ujednolicenie jest bardzo trudne [Józefczyk i in. 2018]. Zbioru dokonuje się na początku kwitnienia. Podczas pozyskiwania obrywa się całe kwiatostany, a następnie delikatnie oddziela brzeżne kwiaty języczkowe. Są one niezwykle delikatne, co nastręcza trudności w otrzymaniu surowca wysokiej jakości. Kwiat rurkowy stanowi zanieczyszczenie organiczne, którego należy unikać. Suszenie powinno przebiegać szybko i niezwłocznie po odseparowaniu frakcji. Czas suszenia uwarunkowany jest od metody. Może przebiegać naturalnie w przewiewnym i cienistym miejscu lub suszarni powietrznej. W przypadku suszenia strumieniem powietrza ogrzewanie nie powinno być wyższe niż $45^{\circ} \mathrm{C}$, gdyż powoduje rozkład cennych składników. Maksymalny czas tego procesu powinien wynosić 2 dni [Senderski 2004].

Płatki chabra, odpowiednio przygotowane i przechowywane, powinny wykazywać niemal niezmienioną barwę, co świadczy o ich właściwościach i przydatności do spożycia. Gdy surowiec zaczyna blaknąć, traci związki czynne, głównie antocyjany odpowiadające za specyficzny i intensywny kolor (cyjaninę i pelargoninę), flawonoidy oraz witaminy. $\mathrm{W}$ częściach zielonych zawiera substancję goryczkową - knicynę, zwaną też centauryną, zaś w kwiatach obecne są cyjanina i cichoryna [Tomczak 2007].

\section{Chaber bławatek - właściwości}

Właściwości kwiatów chabra bławatka wynikają z ich składu chemicznego. Ważnym składnikiem kwiatów są antocyjany. Nazwa ta została po raz pierwszy użyta w 1835 r. przez Ludwiga Marquarta, niemieckiego farmaceutę, do określenia niebieskich barwników kwiatów chabra [Gosh i in. 2007]. Antocyjany należą do polifenolowych związków organicznych - flawonoidów, charakteryzujących się szkieletem węglowym C6-C3-C6. W poszczególnych gatunkach roślin występuje od kilku do kilkunastu antocyjanów, które charakteryzują się zróżnicowaną barwą, od pomarańczowej poprzez różne odcienie czerwieni i fioletu aż do barwy niebieskiej, co uwarunkowane jest ich budową. W ostatnim czasie koncerny zajmujące się barwnikami używanymi w produkcji żywności zachęcają do używania tych naturalnych, ze względu na to, iż są uważane za bezpieczniejsze od syntetycznych [Piątkowska i in. 2011, Pires i in. 2018]. Jako związki wszechobecne w roślinach stanowią istotny element w diecie człowieka. Szacuje 
się, że człowiek w ciągu dnia spożywa przeciętnie ok. $1 \mathrm{~g}$ związków flawonoidowych [Majewska i in. 2009]. Wszystko jednak zależy od nawyków żywieniowych i ilości związków flawonoidowych w spożywanych z dietą produktach. W kwiatach chabra bławatka obecne są antocyjany, tj. cyjanina i jej pochodne [Tomczak 2007]. Cyjanina jest jednym z 17 występujących naturalnie antocyjanów, które są autoryzowanymi przez Unię Europejską barwnikami o symbolu E163 [Piątkowska i in. 2011]. Zawartość flawonoidów w przeliczeniu na kwercetynę w bławatku określono na 1,31-2,72 mg/100g s.m. [Marian i in. 2017]. Chiru [2009] w swoich badaniach nad składem chemicznym kwiatostanów bławatka zaobserwowała najwyższą koncentrację frakcji flawonoidowych w kwiatach koloru fioletowego $(0,21-0,22 \%)$ oraz różowego $(0,19 \%)$, przy czym najwięcej antocyjanów zaobserwowano w kwiatach fioletowych $(1,36-3,68 \%)$ oraz niebieskich $(0,24-0,67 \%)$.

Bławatek, mimo że jest chwastem rosnącym na łąkach i w zbożu, z uwagi na obecność antocyjanów jest rośliną charakteryzującą się szeregiem właściwości prozdrowotnych. Prozdrowotnego charakteru nadaje mu zdolność antyoksydacyjna, która przede wszystkim przeciwdziała uszkodzeniom komórek na skutek działalności wolnych rodników. Ponadto antycyjany uczestniczą w wielu procesach pozytywnie wpływających na układ odpornościowy [Wałejko 2015]. Przypisuje się im właściwości przeciwzapalne, przeciwcukrzycowe, a także zapobiegające powstawaniu nowotworów. Do właściwości leczniczych bławatka można zaliczyć głównie moczopędność, dzięki czemu stanowi substancję wspomagającą w leczeniu zarówno zaburzeń czynności nerek, jak i ogólnych stanów zapalnych dróg moczowych [Tomczak 2007]. Barwniki antocyjanowe poprawiają jakość widzenia dzieki wspomaganiu produkcji rodopsyny oraz jej regeneracji. Dostarczanie ich wraz z dietą pozytywnie wpływa również na budowanie odporności oraz walkę $\mathrm{z}$ reaktywnymi formami tlenu $\mathrm{w}$ organizmie. Działanie przeciwutleniające wiązać się może z bezpośrednim działaniem na rodniki, usuwaniem ich czy osłabieniem ich reaktywności [Gosh i in. 2007, Saluk-Juszczak 2010, Piątkowska i in. 2011]. Dodatek chabra bławatka sprawdza się w leczeniu zaburzeń wątroby czy też nieprawidłowej przemiany materii [Wałejko 2015]. Napar 5\% z suszonych koszyczków chabra pomaga w zwalczaniu biegunki oraz wspomaga trawienie i poprawia apetyt. Badania Pivru i in. [2015] nad właściwościami bławatka wskazują, iż zawarte w płatkach polisacharydy wraz z polifenolami pozytywnie oddziaływały na łagodzenie skutków owrzodzenia żołądka wywołane stresem w modelu szczurzym. Autorzy zaobserwowali lepsze działanie podczas podawania tych związków jednocześnie. Podawane oddzielnie również wykazywały pozytywne działanie, jednak było ono istotnie niższe od połączonej dawki. W badaniu użyto również lek ranitydynę, wykorzystywaną $\mathrm{W}$ leczeniu wrzodów. W porównaniu $\mathrm{z}$ ekstraktem $\mathrm{z}$ bławatka zawierającym obie frakcje (ranitydyna $\mathrm{z}$ dodatkiem polisacharydów i flawonoidów) wykazała słabsze działanie lecznicze niż w przypadku podania osobno (ranitydyna z polisacharydami; ranitydyna $\mathrm{z}$ flawonoidami). 
W XX w. angielscy, irlandzcy i francuscy mnichowie używali płatków chabra bławatka do produkcji wina, które potem służyło jako lek na różnego rodzaju dolegliwości, począwszy od niestrawności, poprzez dreszcze, zawroty głowy aż po infekcje górnych dróg oddechowych. Napar z płatków pozytywnie wpływa na reumatyzm, a gorące okłady przynoszą ulgę w bólach stawów [Roberts 2000].

\section{Podsumowanie}

Chaber bławatek, mimo że przez wielu uznawany za pospolity chwast, zasługuje na miano rośliny prozdrowotnej o wysokim potencjale. Dzięki zawartości antocyjanów, m.in. cyjaniny, wykazuje właściwości antyoksydacyjne czy antynowotworowe. Preparaty $\mathrm{z}$ bławatkiem znalazły zastosowanie $\mathrm{w}$ stanach zmęczenia oczu oraz jako suplementy wspomagające pracę układu pokarmowego i wątroby. Ze względu na swój unikalny kolor chaber bławatek jest również atrakcyjnym dodatkiem, poprawiającym walory estetyczne wielu produktów. Płatki tej rośliny warto zatem włączyć do swojej diety w celu zwiększenia wartości żywieniowej finalnych produktów, a także ich uatrakcyjnienia.

\section{Bibliografia}

Chiru T., 2009. Phytochemical of centaurea cyanus L. Sci. Papers USAMV Bucharest, ser. A, 52, 293-297.

Gosh D., Konishi T., 2007. Anthocyaninis and anthocyanin-rich extracts: role in diabetics and eye function. Asia Pacif. J. Clin. Nutr. 16(2), 200-208.

Grzeszczuk M., Kawecka A., 2010. Kwiaty jadalne - właściwości zdrowotne i wykorzystanie kulinarne. Panacea 1(30), 21-23.

Józefczyk A., Kowalska J., 2018. Ocena składu i zastosowanie olejków eterycznych z rodzaju centaurea L. Kosmos. Probl. Nauk Biol. 67 (2), 319-334.

Majewska M., Czeczot H., 2009. Flawonoidy w profilaktyce i terapii. Terapia i Leki 65(5), 369-377.

Marian E., Wicas L., Tunde J., Muresan M., Stan R., Sevastre B., Diaconeasa Z., Ionscu C., Hangan A., 2017. Comparative study on the biologic activity of centaurea cyanus versus calendula officinalis. Pharmacia 6, 940-946.

Mleck J., Rop O., 2011. Fresh edible flowers of ornamental plants. A new source of nutraceutical foods. Trends Food Sci. Tech. 22, 561-569.

Navarro-Gonzalez I., Gonzalez-Barrio R., Garcia-Valverde V., Bautista-Ortin A. B., Peragio M. J., 2015. Nutritional Compositions and Antioxidant Capacity in Edible Flowers: Characterisation of Phenolic Compounds by HPLC-DAD-ESI/MS. Int. J. Mol. Sci. 16, 805-822.

Nowicka B., 2018. Kwiaty w lodziarni i cukierni. Cukiernictwo i Piekarstwo, 6, 8-12.

Nowicka P., Turkiewicz I., Wojdyło A., Tkacz T., 2018. Kwiaty jadalne - właściwości prozdrowotne oraz potencjalne kierunki ich wykorzystania w przemyśle spożywczym. Przem. Ferment. Owoc.-Warz. 1, 8-10.

Piątkowska E., Kopeć A., Leszczyńska T., 2011. Antocyjany - charakterystyka, występowanie i oddziaływanie na organizm człowieka. ŻNTJ 4(77), 24-35.

Pires T., Dias M.I., Barros L., Barreria J., Santos-Buelga C., Ferreira I., 2018. Incorporation of natural colorants obtained from edible flowers in yogurts. LWT - Food Sci. Tech. 97, 668-675. 
Pirvu L., Bubueanu C., Panateli M., Petcu L., Coprean D., 2015. Centaurea cyanus L. Polysyacyharides and polyphenos cooperation in achieving strong rat gastric ulcer protection. Open Chem. 13, 910-921.

Roberts M.J., 2000. Edible \& Medicinals Flowers. The Spearhead Press, 23.

Rop O., Mlcek J., Jurikova T, Neugebauerova J., 2012. Edible flowers - a new promising source of mineral elements. Molecules 17, 6672-6683.

Saluk-Juszczak J., 2010. Antocyjany jako składnik żywności funkcjonalnej stosowanej w profilaktyce układu krążenia. Post. Hig. Med. Dośw. 64, 451-458.

Senderski M.E., 2004. Prawie wszystko o ziołach. Wyd. Mateusz E. Senderski, Podkowa Leśna.

Śmiechowska N., 2018. Czynniki wpływające na atrakcyjność kwiatów jadalnych. Nauki Inż. Technol. 1(28), 42-50.

Tomczak B., 2007. Chaber bławatek - biologia, występowanie i zwalczanie. Ochr. Rośl. 5, 27-29.

Wałejko A., 2015. Kwiaty jadalne - dekoracyjne i pełne wartości odżywczych. Zagadnienia Aktualnie Poruszane przez Młodych Naukowców 2, 122-126.

www.e-ogrodek.pl/a/chaber-blawatek-na-co-stosowac-to-ziolo-i-jak-uprawiac-blawatki-w-ogrodzie20166.html [data dostępu: 19.03.2020]. 


\author{
Magdalena Szydłowska-Tutaj ${ }^{1,3}$, Maciej Combrzyński ${ }^{2,3}$, Urszula Złotek ${ }^{1}$, \\ Piotr Lewko ${ }^{3}$, Marta Krajewska ${ }^{3}$
}

\title{
Wpływ fortyfikacji na jakość wybranych produktów zbożowych
}

Impact of fortification on the quality of selected cereal products

\begin{abstract}
Wstęp
Konsumenci w dzisiejszych czasach nie traktują pożywienia jedynie jako źródła zaspokojenia głodu i podstawowych wartości odżywczych, ale szukają również produktów, które mogą być przydatne w prewencji i/lub leczeniu chorób cywilizacyjnych czy mogą wpływać na poprawę zdrowia psychicznego i dobrego samopoczucia [Minarovičová i in. 2018]. W związku ze zwiększającą się świadomością współczesnych konsumentów coraz częściej sięgają oni po produkty mało przetworzone, niezawierające konserwantów, sztucznych barwników itp. Coraz bardziej powszechne jest pojęcie żywności funkcjonalnej. Koncepcja żywności funkcjonalnej zrodziła się w Japonii w latach 80. ubiegłego wieku. Zgodnie z definicją Functional Food Science in Europe (1999) żywność funkcjonalna to ta, której udowodniono korzystny wpływ na poprawę stanu zdrowia oraz samopoczucia bądź zmniejszenie ryzyka wystąpienia chorób. Ustalono, że żywność funkcjonalna powinna:

- być produktem spożywczym otrzymanym z naturalnych składników,

- stanowić podstawowy element codziennej diety,

- wpływać korzystnie na procesy fizjologiczne organizmu [Kalbarczyk 2012].

W procesie wytwarzania żywności funkcjonalnej pochodzenia roślinnego wyróżnia się 3 główne strategie:

- modyfikowanie składu surowca wyjściowego poprzez sterowanie warunkami uprawy czy też stosowanie modyfikacji genetycznych,

- modyfikowanie procesów technologicznych,

- wzbogacanie produktów w związki o udokumentowanym działaniu prozdrowotnym (fortyfikacja żywności) [Fogliano i Vitaglione 2005].

Ostatnio zauważyć można zwiększone zainteresowanie konsumentów produktami spożywczymi będącymi elementami codziennej diety, które zostały

\footnotetext{
${ }^{1}$ Katedra Biochemii i Chemii Żywności, Wydział Nauk o Żywności i Biotechnologii, Uniwersytet Przyrodniczy w Lublinie

${ }_{2}^{2}$ Katedra Techniki Cieplnej i Inżynierii Procesowej, Wydział Inżynierii Produkcji, Uniwersytet Przyrodniczy w Lublinie

${ }^{3}$ PZZ Lubella GMW Sp. z o.o. Sp.k.
} 
wzbogacone w składniki o udokumentowanych właściwościach prozdrowotnych. Celem niniejszego opracowania jest przegląd badań dotyczących zastosowania fortyfikacji w podnoszeniu jakości prozdrowotnej wybranych produktów zbożowych.

\section{Makaron jako roślinny produkt funkcjonalny}

Systematycznie zwiększające się spożycie makaronu związane jest ze spadkiem konsumpcji produktów, które co najmniej od strony wartości odżywczych bądź zastosowań w kuchni mogą być uznane za jego substytuty, np. ryż, pieczywo. Wartość sprzedaży makaronu w Polsce rośnie ok. 2\% rocznie. Na zmieniające się nawyki żywieniowe ludzi reaguje rynek makaronów m.in. w Polsce [https://www.portalspozywczy.pl/zboza].

Makaron jest podstawowym składnikiem pożywienia w tradycyjnej kuchni włoskiej. Najlepszym surowcem do produkcji makaronu jest semolina z pszenicy durum [Bashir 2012]. Ocena kulinarna jest jednym z najważniejszych czynników komercyjnej akceptacji makaronów. Wielu naukowców podejmuje się wzbogacania makaronów różnymi dodatkami w celu uzyskania nowych właściwości tego produktu. Okazuje się, że makaron był jednym z pierwszych pokarmów, dla których USFDA (U.S. Food and Drug Administration) wydała zezwolenie na wzbogacanie witaminami i żelazem w latach 40. XX wieku [Marconi i Carcea 2001]. Wzrost aktywności antyoksydacyjnej, zwiększenie zawartości białka, zmniejszenie szybkości uwalniania glukozy i zwiększona strawność białka to tylko niektóre cechy, jakie poprawiają się dzięki zastosowaniu wzbogacania makaronów. Należy jednak pamiętać, że fortyfikowanie makaronów nie może pogarszać ich oceny kulinarnej.

\section{Wzbogacanie makaronu w bioaktywne skladniki}

Biorąc pod uwagę wysokie spożycie makaronów, niską zawartość białka i składników bioaktywnych, jest to dobry produkt do fortyfikacji [Muresan i in. 2017]. Z danych literaturowych wynika, że makarony wzbogacane są w różne dodatki, np. warzywa i owoce, przyprawy, zioła, grzyby. Podstawowe surowce do produkcji makaronu, tj. mąkę pszenną pochodzącą z przemiału pszenicy zwyczajnej (Triticum aestivum) czy semolinę, pochodzącą z przemiału pszenicy durum (Triticum durum), zastępuje się wybranymi dodatkami o różnym udziale procentowym.

Ocena makaronu fortyfikowanego różnymi surowcami, które mają właściwości bioaktywne, wymaga szczegółowej analizy. Poza oceną kulinarną przed i po ugotowaniu makaronu ważne jest, aby ocenić, w jakim stopniu makaron zachowa składniki bioaktywne, czy proces obróbki termicznej makaronu nie spowoduje, że dana substancja zostanie wypłukana, a wartość żywieniowa znacznie się 
Tabela 1. Wybrane surowce stosowane do fortyfikowania makaronów

\begin{tabular}{|c|c|c|c|c|c|c|c|}
\hline \multicolumn{2}{|c|}{ Surowiec stosowany do fortyfikacji } & \multirow{2}{*}{$\begin{array}{l}\% \text { udział } \\
\text { dodatku }\end{array}$} & \multirow{2}{*}{$\begin{array}{l}\text { Forma surowca } \\
\text { stosowanego } \\
\text { do wzbogacania }\end{array}$} & \multirow{2}{*}{$\begin{array}{c}\text { Surowiec } \\
\text { podstawowy }\end{array}$} & \multirow{2}{*}{$\begin{array}{l}\text { Działanie } \\
\text { prozdrowotne } \\
\text { fortyfikowanego } \\
\text { makaronu }\end{array}$} & \multirow{2}{*}{ Ocena kulinarna } & \multirow{2}{*}{ Bibliografia } \\
\hline Nazwa polska & Nazwa łacińska & & & & & & \\
\hline Czystek szary & Cistus incanus $\mathrm{L}$. & $1,23,4,5$ & $\begin{array}{l}\text { proszek } \\
\text { z suszonych liści }\end{array}$ & mąka pszenna & $\begin{array}{l}\text { wzrost zawartości } \\
\text { związków fenolowych } \\
\text { przyczynił się do wzro- } \\
\text { stu aktywności antyok- } \\
\text { sydacyjnych }\end{array}$ & $\begin{array}{l}\text { najlepsza ocena } \\
\text { kulinarna makaro- } \\
\text { nu z dodatkiem } \\
1 \% \text { i } 2 \%\end{array}$ & $\begin{array}{l}\text { Lisiecka } \\
\text { i in. [2019] }\end{array}$ \\
\hline Pietruszka natka & $\begin{array}{l}\text { Petroselinum } \\
\text { crispum Mill. }\end{array}$ & $1,2,3,4$ & $\begin{array}{l}\text { proszek } \\
\text { z suszonych liści }\end{array}$ & semolina & $\begin{array}{l}\text { wzrost zawartości } \\
\text { związków fenolowych } \\
\text { przyczynił się do wzro- } \\
\text { stu aktywności antyok- } \\
\text { sydacyjnych }\end{array}$ & - & $\begin{array}{l}\text { Sẹczyk } \\
\text { i in. [2016] }\end{array}$ \\
\hline Fasola zwykła & $\begin{array}{l}\text { Phaseolus } \\
\text { vulgaris } \mathrm{L} \text {. }\end{array}$ & 15,30 & mąka $\mathrm{z}$ fasoli & semolina & $\begin{array}{l}\text { wzrost zawartości kwa- } \\
\text { sów fenolowych przy- } \\
\text { czynił się do wzrostu } \\
\text { aktywności antyoksyda- } \\
\text { cyjnych }\end{array}$ & $\begin{array}{l}\text { wzrost straty po } \\
\text { ugotowaniu, } \\
\text { jędrność makaronu } \\
\text { maleje wraz ze } \\
\text { wzrostem dodatku } \\
\text { mąki z fasoli }\end{array}$ & $\begin{array}{l}\text { Gallegos- } \\
\text {-Infante } \\
\text { i in. [2010] }\end{array}$ \\
\hline $\begin{array}{l}\text { Mączka chleba } \\
\text { świętojańskiego }\end{array}$ & $\begin{array}{l}\text { Ceratonia } \\
\text { siliqua } \mathrm{L} .\end{array}$ & $1,2,3,4,5$ & mąka & mąka pszenna & $\begin{array}{l}\text { wzrost zawartości } \\
\text { związków fenolowych } \\
\text { przyczynił się do wzro- } \\
\text { stu aktywności antyok- } \\
\text { sydacyjnych }\end{array}$ & $\begin{array}{l}\text { akceptowalna } \\
\text { ocena kulinarna do } \\
4 \% \text { wzbogacenia }\end{array}$ & $\begin{array}{l}\text { Biernacka } \\
\text { i in. [2017] }\end{array}$ \\
\hline Skórka cebuli & Allium cepa $\mathrm{L}$. & $2,5,5,7,5$ & $\begin{array}{l}\text { proszek } \\
\text { Z wysuszonej } \\
\text { skórki z cebuli }\end{array}$ & semolina & $\begin{array}{l}\text { wzrost całkowitej zawar- } \\
\text { tości związków fenolo- } \\
\text { wych, flawonoidów } \\
\text { i zdolności antyoksyda- } \\
\text { cyjnej }\end{array}$ & $\begin{array}{l}\text { dodatek w stężeniu } \\
2,5 \% \text { nie dawał } \\
\text { negatywnych, } \\
\text { niepożąanych } \\
\text { cech makaronu }\end{array}$ & $\begin{array}{l}\text { Michalak- } \\
\text {-Majewska } \\
\text { i in. [2020] }\end{array}$ \\
\hline
\end{tabular}


cd. tab. 1

\begin{tabular}{|c|c|c|c|c|c|c|c|}
\hline $\begin{array}{l}\text { Korzeń selera } \\
\text { i pulpa } \\
\text { z buraków } \\
\text { cukrowych }\end{array}$ & $\begin{array}{l}\text { Beta vulgaris, } \\
\text { Apium } \\
\text { graveolens } \mathrm{L} \text {. }\end{array}$ & $\begin{array}{l}5,7,5 \\
10,20\end{array}$ & $\begin{array}{l}\text { proszek z pulpy } \\
\text { buraczanej } \\
\text { i korzeni selera } \\
\text { (wysuszony } \\
\text { i zmielony) }\end{array}$ & mąka pszenna & $\begin{array}{l}\text { dobre źródło błonnika } \\
\text { pokarmowego }\end{array}$ & $\begin{array}{l}\text { korzeń selera- } \\
\text { akceptowalny } \\
\text { smak i zapach do } \\
\text { poziomu } 10 \% \\
\text { pulpa buraczana - } \\
\text { szary kolor, nieza- } \\
\text { dowalający smak }\end{array}$ & $\begin{array}{l}\text { Minarovičová } \\
\text { i in. [2018] }\end{array}$ \\
\hline Witnik czerwony & $\begin{array}{l}\text { Pseudophycis } \\
\text { bachus }\end{array}$ & $5,10,15,20$ & $\begin{array}{l}\text { proszek } \\
\text { z ugotowanej, } \\
\text { wysuszonej, } \\
\text { zmielonej ryby }\end{array}$ & semolina & $\begin{array}{l}\text { wzrost zawartości ami- } \\
\text { nokwasów, białka, } \\
\text { większa strawność } \\
\text { skrobi i potencjał anty- } \\
\text { oksydacyjny, znaczące } \\
\text { zmniejszenie uwalniania } \\
\text { glukozy podczas trawie- } \\
\text { nia makaronu w modelu } \\
\text { in vitro }\end{array}$ & $\begin{array}{l}\text { konieczne są } \\
\text { dalsze prace w } \\
\text { celu oceny akcep- } \\
\text { towalności kon- } \\
\text { sumenckiej maka- } \\
\text { ronu wzbogacone- } \\
\text { go proszkiem } \\
\text { rybnym }\end{array}$ & $\begin{array}{l}\text { Desai } i \text { in. } \\
{[2018]}\end{array}$ \\
\hline Groszek żółty & $\begin{array}{l}\text { Lathyrus } \\
\text { pratensis } \mathrm{L} .\end{array}$ & $10,20,30$ & $\begin{array}{l}\text { mąka z żółtego } \\
\text { grochu }\end{array}$ & semolina & $\begin{array}{l}\text { zmniejszenie uwalniania } \\
\text { glukozy i zwiększona } \\
\text { strawność białka }\end{array}$ & $\begin{array}{l}\text { makaron z 20\% } \\
\text { dodatkiem mąki } \\
\text { z żółtego grochu } \\
\text { wykazywał ko- } \\
\text { rzystne właściwo- } \\
\text { ści sensoryczne, } \\
\text { dobrą teksturę } \\
\text { i wartość zażółcenia }\end{array}$ & $\begin{array}{l}\text { Shreenithee } \\
\text { i Prabhasankar } \\
\text { [2013] }\end{array}$ \\
\hline
\end{tabular}


obniży. W danych literaturowych można spotkać bardzo różny skład recepturowy makaronu z dodatkiem składników bioaktywnych.

Surowce wykorzystywane do wzbogacenia makaronu można podzielić na kilka grup:

1. Zioła:
a) oregano [Boroski i in. 2011],
b) natka pietruszki [Sẹczyk i in. 2016],
c) czystek [Lisiecka i in. 2019].

2. Warzywa:
a) wytłoki z marchwi [Rekha i in. 2013],

b) szpinak, pomidory [Rekha $i$ in. 2013].

3. Rośliny strączkowe:
a) żółty groszek [Shreenithee i Prabhasankar 2013],
b) groch włoski [Bashir 2012],
c) biała fasola [Gallegos-Infante i in. 2010].

4. Pseudozboża: amarantus.

5. Specyficzne rośliny:
a) mączka chleba świętojańskiego [Biernacka i in. 2017],
b) glony wakame [Sęczyk i in. 2016],
c) chia [Sęczyk i in. 2016].

6. Produkty uboczne:
a) skórka cebuli [Michalak-Majewska i in. 2020],
b) wytłoki z winogron [Sant'Anna i in. 2014],
c) korzeń selera, pulpa buraczana [Minarovičová i in. 2018].

7. Grzyby:
a) borowik szlachetny [Muresan i in. 2017],
b) shiitake [Lu i in. 2016],
c) pieczarka dwuzarodnikowa [Lu i in. 2016].

8. Inne
a) ryba, witnik czerwony [Desai $\mathrm{i}$ in. 2018],

Użycie szerokiej gamy dodatków do produkcji fortyfikowanych makaronów powoduje, że mogą one wykazywać różnorodne właściwości prozdrowotne tabela 1.

\section{Grzyby jako dodatek do produktów spożywczych}

Grzyby od dawna cenione są przede wszystkim za smak i aromat, stosowane głównie do potraw lub przeznaczane na przetwory kiszone lub marynowane. Cenione są również w medycynie ludowej, głównie Chin, Japonii, Malezji. Grecy uznawali grzyby za pokarm bogów, Egipcjanie podawali je tylko faraonom. Świadomość, że grzyby zalicza się do żywności prozdrowotnej, zawierającej 
wiele substancji bioaktywnych, jest stosunkowo nowa [Siwulski i in. 2014]. W prawodawstwie krajowym istnieje wykaz grzybów dopuszczonych do obrotu lub produkcji przetworów grzybowych oraz środków spożywczych zawierających grzyby, który jest załącznikiem do Rozporządzenia Ministra Zdrowia z dnia 17 maja $2011 \mathrm{r}$ (wraz z póź. zm.), i obecnie lista ta zawiera 47 pozycji [Rozporządzenie Ministra Zdrowia $z$ dn. 17 maja 2011].

W związku z korzystnymi właściwościami grzybów naukowcy zainteresowali się owocnikami grzybów jadalnych, najpierw w Japonii i Chinach, później w Europie, gdzie przeprowadzono szczegółowe badania naukowe, których wyniki miały być podstawą do potwierdzenia prawdziwości przekazów tradycyjnej medycyny chińskiej na temat zbawiennych właściwości leczniczych grzybów.

Grzyby są również wykorzystywane w przemyśle farmaceutycznym. Najwcześniej do praktycznego wykorzystania w medycynie (jako rejestrowany produkt farmaceutyczny) trafiły leki o charakterze silnych immunomodulatorów, które zawierają substancje aktywne biologiczne ekstrahowane z owocników grzybów. Później pojawiły się preparaty lecznicze przeciwwirusowe i przeciwbakteryjne.

\section{Substancje czynne grzybów determinujące ich właściwości prozdrowotne}

\section{Polisacharydy}

Cukry występują w największej ilości w suchej masie owocników grzybów. Polisacharydy grzybowe w zależności od gatunku, z jakiego pochodzą, charakteryzują się różną aktywnością przeciwnowotworową [Kalbarczyk 2012]. Działanie przeciwnowotworowe jest najlepiej udokumentowane i najbardziej obiecujące ze wszystkich właściwości grzybów. Maczużnik bojowy (Cordyceps militaria) był długo wykorzystywany w medycynie chińskiej do leczenia chorych na nowotwory. Natomiast w Europie Wschodniej do leczenia chorób nowotworowych wykorzystywano owocniki grzyba włóknouszka ukośna (Inonotus obliquus) [Kalbarczyk 2012]. Po raz pierwszy właściwości przeciwnowotworowe grzybów zostały potwierdzone w szeroko zakrojonych badaniach opisanych przez Lucasa [Lucas i in. 1957] w 1957, który izolując substancję (polisacharydy) z owocników borowika szlachetnego (Boletus edulis), podawał ją myszom chorującym na mięsaka [Zhang i in. 2007]. Preparat ten wykazał znaczące działanie hamujące komórki nowotworowe (S-180) mięsaka [Ren i in. 2012]. Ten sam naukowiec wyizolował kalwacynę z grzybów o nazwie purchawica olbrzymia (Calvatia gigantea), która okazała się skuteczna w leczeniu mięsaka i białaczki [Rajewska i Bałasińska 2004]. Zdolność polisacharydów, zawartych w grzybach jadalnych, do hamowania komórek nowotworowych znacznie się różni w zależności od pochodzenia i budowy.

Głównymi polisacharydami w grzybach są glukany będące polimerami glukozy $\mathrm{z}$ różnymi rodzajami wiązań glikozydowych, takimi jak $(1 \rightarrow 3),(1 \rightarrow 6) \beta$-glukany $\mathrm{i}(1 \rightarrow 3) \alpha$-glukany. Ponadto w grzybach występuje kilka hetero- $\beta$ glukanów. Najwyższą aktywność przeciwnowotworową wykazują $\beta$-glukany o dużej masie czą- 
steczkowej, zawierające głównie wiązania $\beta(1 \rightarrow 3)$ [Rajewska i Bałasińska 2004]. W niektórych gatunkach grzybów polisacharydy wiążące się z białkami lub peptydami, tworząc kompleksy polisacharyd-białko lub polisacharyd-peptyd, cechują się wyższą aktywnością przeciwnowotworową. Bardzo silne właściwości antynowotworowe wykazuje $\beta$-glukan o nazwie lentinan (masa cząsteczkowa wynosi 400-800 $\cdot 10^{3} \mathrm{Da}$ ) wyizolowany $\mathrm{z}$ twardziaka jadalnego (Lentinus edodes). Działanie tego związku nie niszczy komórek nowotworowych, wpływa jednak na zahamowanie dalszego rozwoju. Lentinan pobudza układ odpornościowy, miejscowo aktywuje również m.in. makrofagi, granulocyty, komórki tuczne [Rajewska i Bałasińska 2004]. Kolejnym ważnym polisacharydem pochodzenia grzybowego jest schizofilan (o masie cząsteczkowej $450 \cdot 10^{3} \mathrm{Da}$ ), wyizolowany z rozszczepki pospolitej (Schizophyllum commune), grifolan pochodzący z żagwicy listkowatej (Grifola frondosa). Na przeciwnowotworową aktywność polisacharydów może mieć wpływ rozmiar cząsteczek, stopień rozgałęzienia, forma i rozpuszczalność w wodzie [Ren $\mathrm{i}$ in. 2012].

\section{Terpenoidy}

Bardzo ważną grupą związków bioaktywnych, którą można znaleźć w grzybach, są triterpenoidy o małej masie cząsteczkowej. Związki te wykazują właściwości przeciwwirusowe, szczególnie przeciwko wirusowi opryszczki i HIV. Do innych działań triterpenoidów należą: hamowanie syntezy cholesterolu, obniżanie ciśnienia krwi oraz pozytywny wpływ na choroby wieńcowo-naczyniowe [Kalbarczyk 2012].

\section{Związki fenolowe}

O właściwościach antyoksydacyjnych decydują zawarte w grzybach związki fenolowe, które wykazują również działanie przeciwzapalne i przeciwnowotworowe. Bogate w związki fenolowe są różne gatunki grzybów, np. soplówka jeżowata (Hericium erinaceus), żagwica listkowata (Grifola frondosa), boczniak ostrygowaty (Pleurotus ostreatus), płomiennica zimowa (Flammulina velutipes) [Kalbarczyk 2012].

Grzyby stanowią również bogate źródło naturalnych antybiotyków, mają działanie przeciwalergiczne, wywierają wpływ na ośrodkowy układ nerwowy, co jest wykorzystywane np. w leczeniu choroby Alzhaimera. Wiele gatunków wykazuje działanie przeciwzapalne, np. w zapaleniu stawów [Ren i in. 2012].

$\mathrm{Z}$ uwagi na omawiane powyżej cenne właściwości prozdrowotne grzybów podjęte zostały próby wykorzystania ich $\mathrm{w}$ fortyfikacji produktów zbożowych, takich jak makaron i chleb (tab. 2). Wzbogacanie produktów zbożowych proszkami z suszonych grzybów w wielu przypadkach skutkuje zwiększeniem wartości prozdrowotnej tych produktów, ale może pogarszać ich właściwości kulinarne (tab. 2). 
Tabela 2. Zastosowanie suszów grzybowych w fortyfikacji makaronu i innych produktów zbożowo-mącznych

\begin{tabular}{|c|c|c|c|c|c|c|c|c|}
\hline \multirow{2}{*}{$\begin{array}{l}\text { Wyrób } \\
\text { gotowy }\end{array}$} & \multicolumn{2}{|c|}{ Nazwa dodawanego grzyba } & \multirow{2}{*}{$\begin{array}{l}\% \text { udział } \\
\text { dodatku }\end{array}$} & \multirow{2}{*}{$\begin{array}{l}\text { Forma } \\
\text { dodatku }\end{array}$} & \multirow{2}{*}{$\begin{array}{c}\text { Surowiec } \\
\text { podstawowy }\end{array}$} & \multirow{2}{*}{$\begin{array}{l}\text { Działanie } \\
\text { prozdrowotne } \\
\text { produktu }\end{array}$} & \multirow{2}{*}{ Ocena kulinarna } & \multirow{2}{*}{ Bibliografia } \\
\hline & $\begin{array}{l}\text { Nazwa } \\
\text { polska }\end{array}$ & $\begin{array}{c}\text { Nazwa } \\
\text { lacińska }\end{array}$ & & & & & & \\
\hline Makaron & $\begin{array}{l}\text { borowik } \\
\text { szlachetny }\end{array}$ & Boletus edulis & 10,20 & $\begin{array}{l}\text { proszek } \\
\text { z suszu } \\
\text { grzybowego }\end{array}$ & $\begin{array}{l}\text { mąka } \\
\text { pszenna }\end{array}$ & $\begin{array}{l}\text { wzrost zawartości } \\
\text { białka, wzrost } \\
\text { właściwości antyok- } \\
\text { sydacyjnych } \\
\end{array}$ & $\begin{array}{l}\text { ocena kulinarna } \\
\mathrm{z} \text { dodatkiem } 10 \% \\
\text { porównywalna } \mathrm{z} \text { próbą } \\
\text { zerową }\end{array}$ & $\begin{array}{l}\text { Muresan i in. } \\
\text { [2017] }\end{array}$ \\
\hline Makaron & $\begin{array}{l}\text { borowik } \\
\text { szlachetny }\end{array}$ & Boletus edulis & $5,10,15$ & $\begin{array}{l}\text { proszek } \\
\text { z suszu } \\
\text { grzybowego }\end{array}$ & semolina & \multirow{3}{*}{$\begin{array}{l}\text { makaron wzbogaco- } \\
\text { ny w błonnik po- } \\
\text { karmowy, białko } \\
\text { i inne bioaktywne } \\
\text { składniki }\end{array}$} & \multirow{3}{*}{$\begin{array}{l}\text { negatywne skutki dla } \\
\text { gotowania i właściwości } \\
\text { tekstury, tj. wzrost strat } \\
\text { po gotowaniu i spadek } \\
\text { jędrności wraz ze wzro- } \\
\text { stem dodatku }\end{array}$} & \multirow{3}{*}{$\begin{array}{l}\text { Lu i in. } \\
{[2016]}\end{array}$} \\
\hline Makaron & $\begin{array}{l}\text { pieczarka } \\
\text { dwuzarodnikowa }\end{array}$ & $\begin{array}{l}\text { Agaricus } \\
\text { bisporus }\end{array}$ & $5,10,15$ & $\begin{array}{l}\text { proszek } \\
\text { z suszu } \\
\text { grzybowego }\end{array}$ & semolina & & & \\
\hline Makaron & shiitake & $\begin{array}{l}\text { Lentinula } \\
\text { edodes }\end{array}$ & $5,10,15$ & $\begin{array}{l}\text { proszek } \\
\text { z suszu } \\
\text { grzybowego }\end{array}$ & semolina & & & \\
\hline Chleb & $\begin{array}{l}\text { boczniak } \\
\text { ostrygowaty }\end{array}$ & $\begin{array}{l}\text { Pleurotus } \\
\text { ostreatus }\end{array}$ & $1,2,3,4$ & $\begin{array}{l}\text { proszek } \\
\text { z suszonych } \\
\text { grzybów }\end{array}$ & $\begin{array}{l}\text { mąka } \\
\text { pszenna }\end{array}$ & brak danych & $\begin{array}{l}\text { wzrost masy bochenka, } \\
\text { wodochłonności } \\
\text { zmniejszenie objętości } \\
\text { bochenka }\end{array}$ & $\begin{array}{l}\text { Hong } \mathrm{i} \text { in. } \\
{[2005]}\end{array}$ \\
\hline Chleb & $\begin{array}{l}\text { żagwica } \\
\text { listkowata }\end{array}$ & $\begin{array}{l}\text { Grifola } \\
\text { frondosa }\end{array}$ & $\begin{array}{l}0,14,0,17 \\
0,034, \\
0,069,0,1\end{array}$ & $\begin{array}{l}\text { proszek } \\
\text { z suszonych } \\
\text { grzybów }\end{array}$ & $\begin{array}{l}\text { mąka } \\
\text { pszenna }\end{array}$ & brak danych & $\begin{array}{l}\text { drastycznie spadała } \\
\text { wytrzymałość ciasta, } \\
\text { pogorszenie właściwo- } \\
\text { ści wypiekowych }\end{array}$ & $\begin{array}{l}\text { Seguchi } i \text { in. } \\
\text { [2001] }\end{array}$ \\
\hline
\end{tabular}




\section{Podsumowanie}

Produkcja makaronu to szybko rozwijający się segment przemysłu spożywczego, a rosnąca popularność tego produktu sprawiła, że na całym świecie stanowi element zdrowej żywności. Jak wykazują badania wielu naukowców, makaron ze względu na swój prosty, podstawowy skład surowcowy stanowi dobrą matrycę do fortyfikacji. Badania wykazały [Desai i in. 2018], że można fortyfikować makaron proszkiem z ryby, który z punktu widzenia konsumenta wydaje się nieatrakcyjnym surowcem. Proszek z ryby jest nie tylko dobrym źródłem białka, ale również aminokwasów i kwasów omega-3. Poszukuje się dodatków do żywności, które będą miały korzystny wpływ na nasze zdrowie, aby pomóc w walce z różnymi chorobami, np. cukrzycą, otyłością, nowotworami, a jednocześnie nie będą pogarszały właściwości kulinarnych. Coraz więcej badań nad fortyfikacją makaronów dotyczy dodatku suszu z grzybów, które przez ok. 300 mln lat, już w czasach prehistorycznych, prawdopodobnie były wykorzystywane jako żywność i w celach leczniczych. W miarę rozwoju cywilizacji grzyby były cenione jako jadalne i lecznicze zasoby, zwłaszcza w krajach azjatyckich [Ren i in. 2012].

Sfinansowano przez Ministerstwo Nauki i Szkolnictwa Wyższego w ramach programu Doktorat Wdrożeniowy I (DWD/3/58/2019)

\section{Bibliografia}

Bashir K., 2012. Physio-Chemical and Sensory Characteristics of Pasta Fortified With Chickpea Flour and Defatted Soy Flour. IOSR J. Environ. Sci. Toxicol. Food Technol. 1(5), 34-39. https://doi.org/10.9790/2402-0153439

Biernacka B., Dziki D., Gawlik-Dziki U., Różyło R., Siastała M., 2017. Physical, sensorial, and antioxidant properties of common wheat pasta enriched with carob fiber. LWT - Food Sci. Technol. 77, 186-192. https://doi.org/10.1016/j.lwt.2016.11.042

Boroski M., de Aguiar A.C., Boeing J.S., Rotta E.M., Wibby C.L., Bonafé E.G., de Souza N.E., Visentainer J.V., 2011. Enhancement of pasta antioxidant activity with oregano and carrot leaf. Food Chem. 125(2), 696-700. https://doi.org/10.1016/j.foodchem.2010.09.068

Desai A.S., Brennan M.A., Brennan C.S., 2018. Effect of fortification with fish (pseudophycis bachus) powder on nutritional quality of durum wheat pasta. Foods 7(4), 1-12. https://doi.org/10.3390/foods7040062

Fogliano V., Vitaglione P., 2005. Functional foods: Planning and development. Mol. Nutr. Food Res. 49(3), 256-262. https://doi.org/10.1002/mnfr.200400067

Gallegos-Infante J.A., Rocha-Guzman N.E., Gonzalez-Laredo R.F., Ochoa-Martínez L.A., Corzo N., Bello-Perez L.A., Medina-Torres L., Peralta-Alvarez L.E., 2010. Quality of spaghetti pasta containing Mexican common bean flour (Phaseolus vulgaris L.). Food Chem. 119(4), 1544-1549. https://doi.org/10.1016/j.foodchem.2009.09.040

Hong G.-H., Kim Y.-S., Song G.-S., 2005. Effect of Oyster Mushroom (Pleurotus ostreatus) Powder on Bread Quality. In Prev. Nutr. Food Sci. Vol. 10(3), 214-218. https://doi.org/10.3746/jfn.2005.10.3.214

https://www.portalspozywczy.pl/zboza [data dostępu: 20.03.2020].

Kalbarczyk J. (2012). Mykologia przemysłowa. WUP, Lublin. 
Lu X., Brennan M.A., Serventi L., Mason S., Brennan C.S., 2016. How the inclusion of mushroom powder can affect the physicochemical characteristics of pasta. Int. J. Food Sci. Technol. 51(11), 2433-2439. https://doi.org/10.1111/ijfs. 13246

Michalak-Majewska M., Teterycz D., Muszyński S., Radzki W., Sykut-Domańska E., 2020. Influence of onion skin powder on nutritional and quality attributes of wheat pasta. PLoS ONE 15(1). https://doi.org/10.1371/journal.pone.0227942

Minarovičová L., Lauková M., Kohajdová Z., Karovičová J., Dobrovická D., Kuchtová V., 2018. Qualitative properties of pasta enriched with celery root and sugar beet by-products. Czech J. Food Sci. 36(1), 66-72. https://doi.org/10.17221/242/2017-CJFS

Muresan C.C., Farcas A., Man S., Suharoschi, R., Vlaic, R.A., 2017. Obtaining a functional product through the exploitation of mushroom flour in pasta. Food Sci. Technol. 74(1), 17. https://doi.org/10.15835/buasvmen-fst:12641

Rajewska J., Bałasińska B., 2004. Związki biologicznie aktywne zawarte w grzybach jadalnych i ich korzystny wpływ na zdrowie. Post. Hig. Med. Dosw. 58, 352-357. http://www.phmd.pl/api/files/view/1765.pdf

Rekha M.N., Chauhan A.S., Prabhasankar P., Ramteke R.S., Venkateswara Rao G., 2013. Influence of vegetable purees on quality attributes of pastas made from bread wheat (T. aestivum). CYTA - J. Food 11(2), 142-149. https://doi.org/10.1080/19476337.2012.708881

Ren L., Perera C., Hemar Y., 2012. Antitumor activity of mushroom polysaccharides: A review. Food Funct. 3(11), 1118-1130. https://doi.org/10.1039/c2fo10279j

Rozporządzenie Ministra Zdrowia z dnia 17 maja 2011 r. w sprawie grzybów dopuszczonych do obrotu lub produkcji przetworów grzybowych, środków spożywczych zawierających grzyby oraz uprawnień klasyfikatora grzybów i grzyboznawcy. Dz.U. Nr 115, poz. 672, 115(672), 6995-7006.

SantAnna V., Christiano F.D.P., Marczak L.D.F., Tessaro I.C., Thys, R.C. S., 2014. The effect of the incorporation of grape marc powder in fettuccini pasta properties. LWT - Food Sci. Technol. 58(2), 497-501. https://doi.org/10.1016/j.lwt.2014.04.008

Sęczyk Ł., Świeca M., Gawlik-Dziki U., Luty M., Czyż J. 2016. Effect of fortification with parsley (Petroselinum crispum Mill.) leaves on the nutraceutical and nutritional quality of wheat pasta. Food Chem. 190, 419-428. https://doi.org/10.1016/j.foodchem.2015.05.110

Sęczyk Ł., Świeca M., Gawlik-Dziki U., 2016. Effect of carob (Ceratonia siliqua L.) flour on the antioxidant potential, nutritional quality, and sensory characteristics of fortified durum wheat pasta. Food Chem. 194, 637-642. https://doi.org/10.1016/j.foodchem.2015.08.086

Seguchi M., Morimoto N., Abe M., Yoshino Y., 2001. Effect of maitake (Grifola frondosa) mushroom powder on bread properties. J. Food Sci. 66(2), 261-264. https://doi.org/10.1111/j.13652621.2001.tb11328.x

Shreenithee C.R., Prabhasankar P., 2013. Effect of different shapes on the quality, microstructure, sensory and nutritional characteristics of yellow pea flour incorporated pasta. J. Food Meas. Charact. 7(4), 166-176. https://doi.org/10.1007/s11694-013-9152-5

Siwulski M., Sobieralski K., Sas-Golak I., 2014. Wartość odżywcza i prozdrowotna grzybów. Food Sci. Technol. 21(1), 16-28. https://doi.org/10.15193/zntj/2014/92/016-028

Zhang M., Cui S. W., Cheung P.C.K., Wang Q., 2007. Antitumor polysaccharides from mushrooms: a review on their isolation process, structural characteristics and antitumor activity. Trends Food Sci. Tech. 18(1), 4-19. https://doi.org/10.1016/j.tifs.2006.07.013 
Joanna Wajs ${ }^{1,2}$, Magdalena Stobiecka ${ }^{1}$

\title{
Znaczenie mlecznych produktów fermentowanych w diecie czlowieka
}

Importance of fermented dairy products in the human diet

\begin{abstract}
Wstęp
W ostatniej dekadzie zanotowano zwiększenie zainteresowania żywnością w kontekście zdrowia człowieka. Mleko oraz produkty fermentowane na jego bazie od dawna stanowiły podstawowy element diety. W łatwy sposób można było pozyskać surowiec, a produkty z niego uzyskane z biegiem czasu zaczęto udoskonalać, stosując różne dodatki, w tym wsady owocowe, ziarna zbóż. Obecne zainteresowanie zdrową żywnością i aktywnym stylem życia skłoniło koncerny mleczarskie do wprowadzenia na rynek atrakcyjnej dla konsumentów gamy produktów z dodatkami funkcjonalnymi. Do tej grupy zalicza się różne szczepy bakterii kwasu mlekowego, zioła oraz kwiaty lub inną żywność określaną mianem superfood, której prozdrowotne działanie zostało udowodnione naukowo [Gimbo i in. 2017].

Do mlecznych produktów fermentowanych zalicza się jogurty oraz napoje mleczne, takie jak: kefiry, mleko acidofilne lub fermentowane, a także kumys. Każdy z nich musi wykazać się odpowiednim, zastrzeżonym dla właściwego produktu składem mikroflory, ponieważ jest jednym z głównych nośników żywności dla komórek probiotycznych. Mikrobiom uzyskiwany w czasie produkcji mlecznych produktów fermentowanych zapewnia trwałość tych produktów, a także nadaje im charakterystyczny smak, zapach oraz teksturę [Peláez i in. 2019].

Wraz z upływem czasu i rozwojem wiedzy z zakresu żywności i żywienia człowieka coraz częściej dowodzono, że mleko oraz produkty fermentowane z niego pozyskiwane wykazują korzystny wpływ na ustrój [Aryana i Olson 2017, Donovan i Hutkins 2018]. Oprócz charakterystycznych cech organoleptycznych mleczne produkty fermentowane zyskały akceptację konsumentów dzięki obecności cennych składników odżywczych, takich jak białko, kwasy tłuszczowe, witaminy czy składniki mineralne. Unikalna matryca tej kategorii żywności poprawia jakość i zwiększa ilość wchłaniania składników odżyw-
\end{abstract}

\footnotetext{
${ }^{1}$ Instytut Oceny Jakości i Przetwórstwa Produktów Zwierzęcych, Wydział Nauk o Zwierzętach i Biogospodarki, Uniwersytet Przyrodniczy w Lublinie

2 joanna.wajs@up.lublin.pl
} 
czych, a ich synergistyczne działanie wspomaga pracę organizmu we współtowarzyszących chorobach, w tym zaburzeniach żołądkowo-jelitowych [Fernandez i Marette 2017, Senadeera i in. 2018].

Celem pracy było dokonanie przeglądu najnowszych doniesień literaturowych z zakresu udokumentowanego wpływu mlecznych produktów fermentowanych na zdrowie człowieka.

\section{Materiał i metody}

Metoda badania dokumentów, metoda analizy, metoda obserwacyjna.

\section{Wyniki badań}

Wnikliwa analiza najnowszych doniesień literaturowych dotyczących mlecznych produktów fermentowanych umożliwiła wskazanie ich korzystnego wpływu na zdrowie, zarówno dzieci, jak i osób dorosłych.

Obecnie na rynku wyróżnić można wiele grup mlecznych produktów fermentowanych, nie tylko naturalnych. Dostępne są również jogurty z dodatkami owocowymi i innymi składnikami pozytywnie oddziałującymi na zdrowie. Wsad owocowy to nie tylko wartość dodana, cechująca się szeroką paletą smaków, ale przede wszystkim źródło cennych składników odżywczych. Dodatki owocowe w mlecznych produktach fermentowanych pomagają utrzymać odpowiednią ilość bakterii probiotycznych w jelitach, a obecność błonnika pokarmowego będzie regulowała procesy defekacyjne.

Dostarczenie wraz z dietą włókna prebiotycznego, tj. fruktooligosachorydów pochodzących z owoców, ma bardzo istotne korzyści zdrowotne. Promuje kolonizację bakterii mlekowych w jelicie grubym, utrzymując tym samym ich balans w okrężnicy. Polifenole pochodzące $\mathrm{z}$ owoców stanowią powszechny wskaźnik zdrowotny i mają za zadanie chronić organizm przed chorobami nowotworowymi, kardiometabolicznymi, cukrzycą typu 2 czy otyłością [Mozaffarian i in. 2011, Slavin 2013, Ruhee i Mahomoodally 2015, Mozaffarian 2016].

Jednakże w przypadku produktów fermentowanych kluczową rolę odgrywa stosowana mikroflora. Na ludzką mikroflorę oddziałuje wiele czynników, lecz największy wpływ wywiera dieta. Spożywanie określonych produktów fermentowanych, w tym jogurtów probiotycznych czy kefirów, wspomaga kontrolę wzrostu mikroflory, dzięki obecności bakterii kwasu mlekowego (LAB) [Thorning i in. 2017, Korcz i in. 2018]. Z tego względu oba produkty wykazują szereg korzystnych działań dla ustroju. Obniżają poziom cholesterolu we krwi, wychwytują i niwelują procesy zapalne czy też wpływają na poprawę funkcji poznawczych osób starszych. Ponadto bakterie fermentacji mlekowej, w szeroko rozumianym ujęciu, stanowią czynnik przeciwnowotworowy, a dzięki produkcji 
bakteriocyn, hamują rozwój bakterii Gram-dodatnich należących do rodzajów Staphylococcus i Listeria oraz bakterii Gram-ujemnych, np. Salmonella, Escherichia, Shigella [Gientka i in. 2016]. Dodatkowo, jogurty wykazują działanie terapeutyczne i profilaktyczne względem chorób układu oddechowego, w tym astmy. Pożyteczne bakterie obecne w jogurtach wspierają organizm w trakcie antybiotykoterapii, zapobiegając powstawaniu biegunek [Kang i in. 2018]. Mleczne produkty fermentowane zmniejszają ryzyko wystąpienia zespołu metabolicznego (MS, ang. metabolic syndrome), który w sposób bezpośredni zagraża zdrowiu, a nawet życiu. Zalicza się tu choroby, takie jak cukrzyca typu 2, choroby sercowo-naczyniowe oraz otyłość brzuszna [Mena-Sánchez i in. 2019].

Jogurty należą do grupy produktów spożywczych, które nadają się do spożycia przez osoby z zespołem złego wchłaniania laktozy, czyli cukru mlecznego. Kultury jogurtowe, takie jak Streptococcus thermophilus czy Lactobacillus delbrueckii subsp. bulgaricus, wytwarzają $\beta$-galaktozydazę, która potencjalnie może poprawić proces wchłaniania laktozy [Kok i Hutkins 2018, Saborido i Leis 2018].

Obecny w jogurtach sprzężony kwas linolowy (CLA, ang. conjugated linoleic acid), wchodzący w skład tłuszczu mlekowego, w nie mniejszym stopniu poprawia parametry zdrowotne. Zmniejsza poziom tkanki thuszczowej, pomaga w utrzymaniu prawidłowego profilu glikemicznego i syntezie glikogenu, a także działa prewencyjnie w stosunku do procesu proliferacji komórek nowotworowych. Wykazano również, że kwas linolowy może wypływać na modulację układu odpornościowego bądź wspomagać proces mineralizacji kości [Lehnen i in. 2015].

Co więcej, Keast i in. [2015] wykazali, że spożywanie jogurtów oraz nabiału korelowało z wyższym spożyciem makroskładników odżywczych, wapnia, witaminy D, a niższym spożyciem tłuszczów wśród dzieci w USA. Z kolei Babio $i$ in. [2015] udowodnili, że spożywanie niskotłuszczowych produktów mlecznych, w tym jogurtu oraz mleka, było związane ze zmniejszonym ryzykiem wystąpienia zespołu metabolicznego wśród populacji śródziemnomorskiej osób starszych (55-80 lat) z wysokim ryzykiem chorób sercowo-naczyniowych. Sayón-Orea i in. [2015] potwierdzili natomiast $w$ badaniach, że spożywanie jogurtów z dodatkami owoców było ściśle skorelowane z otyłością brzuszną. Taką zależność zauważyli również Martinez-Gonzales i in. [2014]. Wykazali bowiem, że spożywanie jogurtu naturalnego było odwrotnie związane z wystąpieniem nadwagi/otyłości niż w przypadku osób spożywających jogurty z owocami. Ponadto Sah [2019] wykazał, że wybrane szczepy bakterii Lactobacillus (L.) acidophilus (ATCC ${ }^{\circledR} 4356^{\mathrm{TM}}$ ), L. casei (ATCC ${ }^{\circledR} 393^{\mathrm{TM}}$ ) i L. paracasei subsp. paracasei (ATCC® BAA52 ${ }^{\mathrm{TM}}$ ) obecne $\mathrm{w}$ jogurcie cechują się szczególnie wysoką aktywnością proteolityczną, dzięki czemu możliwe jest uwalnianie peptydów przeciwnowotworowych obecnych w łańcuchu aminokwasowym białek mleka. Inne badania, przeprowadzone w 2018 r., przy współpracy naukowców z Japonii i Francji, donoszą, że długotrwałe spożywanie jogurtu LB81, którego składnikami są Lactobacillus delbrueckii subsp. bulgaricus 2038 i Streptococcus thermophilus 1131, może potencjalnie utrzymywać homeostazę całego ustroju. Do- 
tyczy funkcji bariery jelitowej, dzięki kontrolowaniu mikrobiomu jelitowego oraz jego metabolitów [Usui i in. 2018].

Akberi i in. [2016] przeprowadzili badania wśród osób dorosłych z chorobą Alzheimera (AD, ang. Alzheimer's disease), w których połowa uczestników $(\mathrm{n}=30)$ przez 12 tygodni przyjmowała $200 \mathrm{ml}$ dziennie mleka probiotycznego zawierającego Lactobacillus acidophilus, Lactobacillus casei, Bifidobacterium bifidum i Lactobacillus fermentum $\left(2 \times 10^{9} \mathrm{CFU} / \mathrm{g}\right.$ dla każdego $)$. Wykazano, że dieta bogata $\mathrm{w}$ probiotyki nie tylko wpływała na prawidłową aktywność mózgu, ale również indukowała znaczną poprawę poznawczą u pacjentów z AD.

\section{Dyskusja}

Obecność aktywnych białek mleka, tj. kazeiny i serwatkowych, wywiera korzystne działanie biologiczne względem układu pokarmowego, nerwowego, immunologicznego, hormonalnego czy krążenia. Fernandez i in. [2017] stwierdzili, że proces fermentacji z wykorzystaniem szczepów bakterii generuje bioaktywne peptydy, które będą zwiększały korzystny wpływ jogurtów na zdrowie metaboliczne niż niefermentowane produkty mleczne, takie jak mleko. Niebywałe znaczenie mlecznych produktów fermentowanych w diecie człowieka potwierdzili również Wang i in. [2013], którzy udowodnili, że jogurty należą do żywności fermentowanej o dużym zasobie mikroelementów i w sposób znaczący mogą przyczynić się do poprawy jakości diety, utrzymania dobrostanu metabolicznego oraz zbilansowanego sposobu żywienia, w kontekście pobieranej dziennej dawki energii.

U osób z chorobą Alzheimera znacznie częściej dochodzi do wystąpienia dyslipidemii, insulinooporności, cukrzycy, otyłości czy zgonów [Sridhar i in. 2015, Schelke i in. 2016]. Dlatego istotnym elementem jest wpływ różnych szczepów bakterii probiotycznych na pracę mózgu oraz funkcji poznawczych [Hort i in. 2020]. Prawidłowe wzorce żywieniowe, w tym ograniczenie cukrów w diecie, spożywanie żywności probiotycznej oraz przyjmowanie wielonienasyconych kwasów thuszczowych omega-3 silnie związana jest z utrzymanie funkcji kognitywnych mózgu [Pisstolatto i in. 2018]. Jednak wiedza, jaką dysponuje świat naukowy na temat zjawisk behawioralnych w kontekście spożywania mlecznych produktów fermentowanych, jest wciąż niewystarczająca i wymaga dalszych badań [Davari i in. 2013].

Jogurty są doskonałym mlecznym produktem fermentowanym, który bez obaw może być spożywany przez osoby z nadwagą czy otyłością. Trembly i in. [2015] wykazali, że spożywanie jogurtów wpłynęło na utrzymanie dziennego bilansu energetycznego oraz kontrolę apetytu w ciągu dnia. Natomiast Douglas $i$ in. [2013] w swoich badaniach wykazali, że spożywanie przekąsek w postaci jogurtów o zwiększonej ilości białka wpłynęło korzystnie na zmniejszenie poczucia głodu oraz zwiększenie sytości poposiłkowej. Odpowiednio niewielki 
procent zawartości tłuszczu daje możliwość spożywania ich przez osoby z nadwagą, otyłością, chorobami układu krążenia czy cierpiącymi na nowotwory. Niskotłuszczowe mleczne produkty fermentowane oraz mleko zmniejszają ryzyko zachorowalności na choroby cywilizacyjne, w tym zespół metaboliczny. Kim i Kim [2017] udowodnili, że spożywanie produktów mleczarskich, w tym mleka oraz jogurtów, wiązało się ze zmniejszonym ryzykiem pojawienia się MS. Również Fumeron i in. [2011] potwierdzili, że obecność w diecie mlecznych produktów fermentowanych skorelowanych $\mathrm{z}$ wysoką zawartością wapnia wpłynęła na zmniejszenie ryzyka wystąpienia MS wśród osób dorosłych.

Istnieją badania [Diaz-López i in. 2016, Lu i in. 2016], które wskazują, że spożywanie niskotłuszczowego mleka, jogurtu czy kefiru wpływa korzystnie na zdrowie, natomiast spożywanie pełnego mleka przyczynia się do zwiększonego ryzyka nowotworu prostaty wśród mężczyzn.

\section{Podsumowanie}

Mleko oraz pozyskiwane $\mathrm{z}$ niego produkty fermentowane wykazują szereg korzyści dla ludzkiego organizmu. Jogurty należą do żywności o niebywałej matrycy, której obecność pozwala na uzupełnienie dziennych dawek witamin oraz składników mineralnych, w tym wapnia, fosforu czy potasu. Żywność bogata $\mathrm{w}$ pre/probiotyki może zapobiegać dysbiozie jelit oraz wspomóc procesy ich leczenia. Mleczne produkty fermentowane z pewnością mogą zostać włączone do codziennej diety również osób borykających się z chorobami przewlekłymi, w tym z chorobą Alzheimera. Obecnie pojawia się wiele przesłanek do podejmowania dalszych badań w celu oszacowania wpływu spożywania mleka oraz mlecznych produktów fermentowanych na umieralność osób ze zdiagnozowanym nowotworem wśród różnych grup etnicznych.

\section{Bibliografia}

Akbari E., Asemi Z., Daneshvar Kakhaki R., Bahmani F., Kouchaki E., Tamtaji O.R., Hamidi G.A., Salami M., 2016. Effect of probiotic supplementation on cognitive function and metabolic status in alzheimer's disease: a randomized, double-blind and controlled trial. Front. Aging Neurosci. 8, 256.

Aryana K.J., Olson D.W., 2017. A 100-Year Review: Yogurt and other cultured dairy products. J. Dairy Sci. 100(12), 9987-10013.

Babio N., Becerra-Tomás N., Martínez-González M.A., Corella D., Estruch R., Ros E., Sayón-Orea C., Fitó M., Serra-Majem L., Arós F., Lamuela- Raventós R.M., Lapetra J., Gómez-Gracia E., Fiol M., Díaz-López A., Sorlí J.V., Martínez J.A., Salas-Salvadó J., 2015. Consumption of yogurt, low-fat milk, and other low-fat dairy products is associated with lower risk of metabolic syndrome incidence in an elderly Mediterranean population. J. Nutr. 145(10), 2308-2316. 
Davari S., Talaei S.A., Alaei H., Salami M., 2013. Probiotics treatment improves diabetes-induced impairment of synaptic activity and cognitive function: behavioral and electrophysiological proofs for microbiome - gut - brain axis. Neuroscience 240, 287-296.

Departament Rolnictwa Stanów Zjednoczonych. Glosariusz terminów rolniczych, https://agclass.nal.usda.gov/glossary.shtml [data dostępu: 24.02.2020].

Donovan S.M., Hutkis R., 2013. Introduction to the fifth global summit on the health effects of yogurt. Nutr., Rev., 76(Suppl 1), 1-3.

Douglas S.M., Ortinau L.C., Hoertel H.A., Leidy H.J., 2013. Low, moderate, or high protein yogurt snacks on appetite control and subsequent eating in healthy women. Appetite 60(1), 117-122.

Fernandez M.A., Marette A. 2017. Potential health benefits of combining yogurt and fruits based on their probiotic and prebiotic properties. Adv. Nutr. 8(1), 155S-164S.

Fernandez M.A., Panahi S., Daniel M., Tremblay A., Marette A., 2017. Yogurt and Cardiometabolic Diseases: A Critical Review of Potential Mechanisms. Adv. Nutr. 8(6), 812-829.

Fumeron F., Lamri, Khalil A.C., Jaziri R., Porchay-Baldérelli I,, Lantieri O., T. S., Balkau B., Marre M. 2011. Dairy consumption and the incidence of hyperglycemia and the metabolic syndrome: results from a french prospective study, Data from the Epidemiological Study on the Insulin Resistance Syndrome (DESIR). Diab. Care 34(4), 813-817.

Gientka I., Bugajewska A., Chlebowska-Śmigiel A., Kieliszek M., Misiura S., 2016. Ocena zdolności przeciwdrobnoustrojowych i bakteriocynogennych Lactobacillus rhamnosus ATCC 7469. Zesz. Probl. Post. Nauk Rol. 585, 65-73.

Gimbo F., Bonanno A., Nocella G., Viscecchia R., Nardone G., De Devitiis B., Carlucci D., 2017. Consumers' acceptance and preferences for nutrition-modified and functional dairy products: a systematic review. Appetite 113, 141-154.

Hort J., Valis M., Angelucci F., 2020. Administration of pre/probiotics with conventional drug treatment in Alzheimer's disease. Neural. Regen. Res. 15(3), 448-449.

Kang S.H., Yu M.S., Kim J.M., Park S.K., Lee C.H., Lee H.G., Kim S.K., 2018. Biochemical, microbiological, and sensory characteristics of stirred yogurt containing red or green pepper (Capsicum annuum cv. Chungyang) juice. Korean J. Food. Sci. Anim. Resour. 38(3), 451-467.

Keast D.R., Hill Gallant K.M., Albertson A.M., Gugger C.K., Holschuh N.M., 2015. Associations between yogurt, dairy, calcium, and vitamin D intake and obesity among U.S. children aged 8-18 years: NHANES, 2005-2008. Nutrients 7(3), 1577-1593.

Kok C., Hutkins R., 2018. Yogurt and other fermented foods as sources of health-promoting bacteria. Nutr. Rev. 76(S1), 4-15.

Korcz E., Kerényi Z., Varga L., 2018. Dietary fibers, prebiotics, and exopolysaccharides produced by lactic acid bacteria: potential health benefits with special regard to cholesterol-lowering effects. Food Funct. 9, 3057-3068.

Lehnen T.E., da Silva M.R., Camacho A., Marcadenti A., Lehnen A.M., 2015. A review on effects of conjugated linoleic fatty acid (CLA) upon body composition and energetic metabolism. J. Int. Soc. Sports Nutr. 12, 36 .

Lu W., Chen H., Niu Y., Wu H., Xia D., Wu Y., 2016. Dairy products intake and cancer mortality risk: a meta-analysis of 11 population-based cohort studies. Nutr. J. 15(1), 91.

Martinez-Gonzales M.A., Sayon-Orea C., Ruiz-Canela M., de la Fuente C., Gea A., Bes-Rastrollo M., 2014. Yogurt consumption, weight change and risk of overweight/obesity: The SUN cohort study. Nutr., Metab. Cardiovasc. Dis. 24, 11, 1189-1196.

Mena-Sánchez G., Becerra-Tomas N., Babio N., Salas-Salvadó J., 2019. Dairy Product Consumption in the Prevention of Metabolic Syndrome: A Systematic Review and Meta-Analysis of Prospective Cohort Studies. Adv. Nutr. 10(suppl. 2), S144-S153.

Mozaffarian D., Hao T., Rimm E.B., Willett W.C., Hu F.B., 2011. Changes in diet and lifestyle and long-term weight gain in women and men. N. Engl. J. Med. 364, 2392-2404.

Mozaffarian D., 2016. Dietary and policy priorities for cardiovascular disease, diabetes, and obesity: a comprehensive review. Circulation 133, 187-225.

Usui Y., Kimura Y., Satoh T., Takemura N., Ouchi Y., Ohmiya H., Kobayashi K., Suzuki H., Koyama S., Hagiwara S., Tanaka H., Imoto S., Eberl G., Asami Y., Fujimoto K., Uematsu S., 
2018. Effects of long-term intake of a yogurt fermented with Lactobacillus delbrueckii subsp. bulgaricus 2038 and Streptococcus thermophilus 1131 on mice. Int. Immunol. 30(7), 319-331.

Peláez C., Martínez-Cuesta M.C., Requena T., 2019. Fermented dairy products. W: How fermented foods feed a healthy gut microbiota. A nutrition continuum, Azcarate-Peril M.A., Arnold R.R., Bruno-Bárcena J.M. (eds.). Springers, Cham, 35-55.

Pistollato F., Iglesias R.C., Ruiz R., Aparicio S., Crespo J., Lopez L.D., Manna P.P., Giampieri F., Battino M., 2018. Nutritional patterns associated with the maintenance of neurocognitive functions and the risk of dementia and Alzheimer's disease: A focus on human studies. Pharmacol. Res. 131, 32-43.

Ruhee D., Mahomoodally F., 2015. Relationship between family meal frequency and individual dietary intake among diabetic patients. J. Diabetes Metab. Disord. 14, 66.

Saborido R., Leis R., 2018. Yogurt and dietary recommendations for lactose intolerance. Nutr. Hosp. 35(6), 45-48.

Sayón-Orea C., Bes-Rastrollo M., Marti A., Pimenta A.M., Martin-Calvo N., Martinez-González M.A., 2015. Association between yogurt consumption and the risk of Metabolic Syndrome over 6 years in the SUN study. BMC Public Health 15, 170.

Slavin J., 2013. Fiber and prebiotics: mechanisms and health benefits. Nutrients 5, 1417-1435.

Senadeera S.S., Prasanna P.PH., Jayawardana NWIA., Gunasekara D.CS., Senadeera P., Chandrasekara A., 2018. Antioxidant, physicochemical, microbiological, and sensory properties of probiotic yoghurt incorporated with various Annona species pulp. Heliyon 4(11), e00955.

Schelke M.W., Hackett K., Chen J. L., Shih C., Shum J., Montgomery M. E., Chiang G.C., Berkowitz C., Seifan A., Krikorian R., Isaacson R.S., 2016. Nutritional interventions for Alzheimer's prevention: a clinical precision medicine approach. Ann N.Y. Acad. Sci. 1367, 50-56.

Sridhar G.R., Lakshmi G., Nagamani G., 2015. Emerging links between type 2 diabetes and Alzheimer's disease. World J. Diab. 6, 744-751.

Thorning T.K., Bertram H.C., Bonjour J.P., de Groot L., Dupont D., Feeney E., Ipsen R., Lecerf J.M., Mackie A., McKinley M.C., Michalski M.C., Rémond D., Risérus U., Soedamah-Muthu S.S., Tholstrup T., Weaver C., Astrup A., Givens I., 2017. Whole dairy matrix or single nutrients in assessment of health effects: current evidence and knowledge gaps. Am. J. Clin. Nutr. 105(5), $1033-1045$

Tremblay A., Doyon C., Sanchez M., 2015. Impact of yogurt on appetite control, energy balance, and body composition. Nutr. Rev. 73(Suppl 1), 23-27.

Wang H., Livingstone K.A., Fox C.S., Meigs J.B., Jacques P.F., 2013. Yogurt consumption is associated with better diet quality and metabolic profile in American men and women. Nutr. Res. 33(1), 18-26. 